Palaeocopid and Podocopid Ostracoda from the Lexington Limestone and Clays Ferry Formation (Middle and Upper Ordovician) of Central Kentucky

GEOLOGICALSURVEY PROFESSIONALPAPER 1066 - H

Prepared in cooperation with the

Commonwealth of Kentucky,

University of Kentucky,

Kentucky Geological Survey

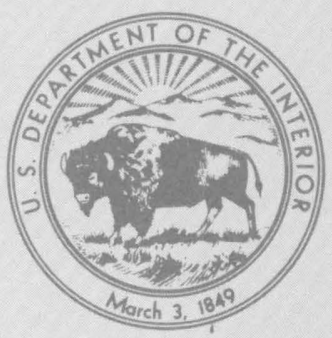



Palaeocopid and Podocopid Ostracoda from the Lexington Limestone and Clays Ferry Formation (Middle and Upper Ordovician) of Central Kentucky

By S. M. WARSHAUER and JEAN M. BERDAN

CONTRIBUTIONS TO THE ORDOVIGIAN PALEONTOLOGY OF KENTUCKY AND NEARBY STATES

Edited by JOHN POJETA, JR.

GEOLOGICAL S U R VEY PROFESIONAL PAPER $1066-\mathrm{H}$

Prepared in cooperation with the

Commonwealth of Kentucky,

University of Kentucky,

Kentucky Geological Survey

Descriptions and illustrations of

54 ostracode taxa, including

5 new genera and 18 new species, with discussions of their

paleoecologic and stratigraphic

significance 


\section{UNITED STATES DEPARTMENT OF THE INTERIOR}

JAMES G. WATT, Secretary

GEOLOGICAL SURVEY

Dallas L. Peck, Director

Library of Congress catalog-card No. 82-600570

For sale by the Distribution Branch, U.S. Geological Survey, 604 South Pickett Street, Alexandria, VA 22304 


\section{CONTENTS}

Abstract

Introduction

Acknowledgements

Previous work

Age and correlation

Paleoecology

List of localities

Systematic paleontology

Order Palaeocopida

Genus Quasibollia n. gen

Genus Warthinia Spivey, 1939

Genus Parenthatia Kay, 1940

Genus Gephyropsis n. gen

Genus Jonesella Ulrich, 1890

Genus Ballardina Harris, 1957

Genus Ctenobolbina Ulrich, 1890

Genus Ceratopsis Ulrich, 1894

Genus Dicranella Ulrich, 1894

Genus Eurychilina Ulrich, 1889

Genus Cystomatochilina Jaanusson, 1957

Genus Platybolbina (Rimabolbina) Schallreuter, 1969

Genus Hesperidella Öpik, 1937

Genus Oepikella Thorslund, 1940

Genus Macronotella Ulrich, 1894

Genus Aparchites Jones, 1889

Genus Brevidorsa Neckaja, 1973

\begin{tabular}{|c|c|}
\hline & \\
\hline & Systematic Paleontology-Continued \\
\hline 1 & Order Palaeocopida-Continued \\
\hline & Genus Saccelatia Kay, 1940 \\
\hline & Genus Anisocyamus Martinsson, 1960 \\
\hline 2 & Genus Leperditella Ulrich, 1894 \\
\hline 4 & Genus Byrsolopsina Swain and Cornell, 1961 \\
\hline 5 & Genus Schmidtella Ulrich, 1892 \\
\hline 14 & Genus Easchmidtella Schallreuter, \\
\hline 19 & Genus Laccoprimita Ulrich and Bas \\
\hline 19 & Genus Milleratia Swartz, 1936 \\
\hline 19 & Genus Uninodobolba n. gen \\
\hline 23 & Genus Ectoprimitia Bouček, 1936 \\
\hline 26 & ngulella $\mathrm{n}$. gen \\
\hline 27 & Genu \\
\hline 27 & Genus $B$ \\
\hline 28 & Genu \\
\hline 29 & Genu \\
\hline 32 & Order \\
\hline 45 & Genu \\
\hline 46 & Genus Shenandoia Kra \\
\hline 46 & Genus Ellipto \\
\hline 47 & Genus Silenis Neckaj \\
\hline 48 & Genus Krau \\
\hline 49 & Genus Pseudo \\
\hline $4 \mathrm{~s}$ & Genus Reversocypris \\
\hline 49 & \\
\hline 50 & \\
\hline
\end{tabular}

Page

$\mathrm{H} 51$

52

52

54

54

56

57

Plate 1. Quasibollia and Warthinia.

[Plates follow index]

2. Parenthatia and Warthinia.

3. Ballardina, Gephyropsis, and Jonesella.

4. Ctenobolbina.

5. Ceratopsis and Hastatellina?.

6, 7. Ceratopsis.

8. Ceratopsis? and Ceratopsis.

9. Hesperidella?, Dicranella, Dicranella?, Platybolbina (Rimabolbina), Apatochilina, Cystomatochilina, Eurychilina.

10. Macronotella?, Saccelatia, Hyperchilarina, Oepikella, "Aparchites," Brevidorsa.

11. Leperditella?, Anisocyamus, Anisocyamus?, and Leperditella

12. Byrsolopsina?, Easchmidtella, and Schmidtella.

13. Laccoprimitia.

14. Milleratia, Laccoprimitia, Ectoprimitia?, and Uninodobolba.

15. Ningulella and Pseudoprimitiella?.

16. Bolbopisthia and Cystomatochilina.

17. Cryptophyllus, Eridoconcha, and Americoncha.

18. Shenandoia?, Elliptocyprites, Phelobythocypris, and Silenis.

19. Reversocypris?, Pseudorayella, and Krausella. 
FIGURE 1. Generalized map of central Kentucky showing Ordovician ostracode localities used in this study

2. Q-mode dendrogram showing the relationship of the 44 quantitatively defined collections to one another

3-10. Histogram of common genera in:
3. Cluster A
4. Cluster B
5. Cluster $\mathrm{C}$
6. Cluster D
7. Cluster $\mathrm{E}$
8. Cluster $F$
9. Cluster $\mathrm{G}$
10. Cluster $\mathrm{H}$

11. Histogram of the single collection in outlier I

12-20. Size-dispersion diagrams for specimens of:

12. Quasibollia persulcata

13. Warthinia nodosa

14. Ballardina millersburgia

15. Ctenobolbina ventrispinifera

17. Ceratopsis intermedia, hypotypes

18. Ceratopsis asymmetrica

19. Ceratopsis intermedia and Ceratopsis asymmetrica

20. Laccoprimitia cryptomorphologica

\section{TABLES}

TABLE 1. Ostracode taxa described in this paper and the stratigraphic units and the collections in which they occur

2. Lithologies of the ostracode-bearing stratigraphic units included in this study

3. Measurements of $\mathbf{1 7}$ specimens of Quasibollia persulcata

4. Statistical summary of measurements for Quasibollia persulcata

5. Measurements of 48 specimens of Warthinia nodosa

6. Statistical summary of measurements for Warthinia nodosa

7-9. Measurements of:

7. Sixteen specimens of Parenthatia sadievillensis

8. Eleven specimens of Jonesella gonyloba

9. Thirteen specimens of Ballardina millersburgia

10. Statistical summary of measurements for Ballardina millersburgia

11. Measurements of 47 carapaces of Ctenobolbina ventrispinifera

12. Statistical summary of measurements for Ctenobolbina ventrispinifera

13. Statistical summary of measurements for the lectotype and paralectotypes of Ceratopsis intermedia

14. Measurements of 22 unfigured hypotypes of Ceratopsis intermedia

15. Statistical summary of measurements for Ceratopsis intermedia

16. Measurements of 83 specimens of Ceratopsis asymmetrica

17. Statistical summary of measurements for Ceratopsis asymmetrica

18-22. Measurements of:

18. Six specimens of Brevidorsa strodescreekensis

19. Three specimens of Leperditella sp. aff. L. tumida

20. Eight specimens of Schmidtella brevis

21. Twenty specimens of Laccoprimitia rudis _._-_-_-_-

22. Sixty-four specimens of Laccoprimitia cryptomorphologica

23. Statistical summary of measurements for Laccoprimitia cryptomorphologica

24-26. Measurements of:

24. Four specimens of Laccoprimitia claysferryensis

25. Twenty-six specimens of Americoncha dubia

26. Eight specimens of Phelobythocypris cylindrica 


\title{
PALAEOCOPID AND PODOCOPID OSTRACODA FROM THE LEXINGTON LIMESTONE AND CLAYS FERRY FORMATION (MIDDLE AND UPPER ORDOVICIAN) OF CENTRAL KENTUCKY
}

\author{
By S. M. WARSHAUER ${ }^{1}$ and JEAN M. BERDAN
}

\begin{abstract}
The Middle through lower Upper Ordovician Lexington Limestone and lower part of the Clays Ferry Formation contain an abundant and diversified ostracode fauna. More than 10,000 specimens belonging to 39 genera and 53 species have been found in 73 collections made by members of the U.S. Geological Survey in cooperation with the Kentucky Geological Survey between 1961 and 1970. Five of the genera and 17 of the species are new. New taxa include the genera Gephyropsis, Ningulella, Phelobythocypris, Quasibollia, and Uninodobolba and the following species: Americoncha dubia, Ballardina millersburgia, Brevidorsa strodescreekensis, Ceratopsis asymmetrica, C. fimbriata, Ctenobolbina ventrispinifera, Cystomatochilina reticulotiara, Easchmidtella sinuidorsata, Gephyropsis trachyreticulata, Jonesella gonyloba, Laccoprimitia claysferryensis, L. cryptomorphologica, Leperditella? perplexa, Ningulella paupera, Parenthatia sadievillensis, Silenis kentuckyensis, and Uninodobolba franklinensis. In addition, a new species, Quasibollia copelandi, is described from the Middle Ordovician of Ontario. The type specimens of ostracodes previously described from these formations but not represented in the recent collections are redescribed and refigured. The genus Warthinia Spivey, 1939 , is reinstated for Ordovician bolliids with two to four nodes, and the genus Ceratopsis Ulrich, 1894, is reviewed with new figures of all known North American species of the genus.

Forty-four collections included enough specimens to warrant quantitative analysis. The temporal and spatial distribution of the genera were defined by using Q-mode cluster analysis based on Sorensen's quantified coefficient of association. The resulting phenogram indicated the existence of eight clusters; these clusters were characterized by calculation of constancy and fidelity measures for each of the variables. Generic diversity, compound generic diversity, and lithologic associations were scanned in an attempt to delineate the paleoecologic regime of each cluster. In general, a trend can be seen in which the higher diversity Phelobythocypris-dominated clusters are found in the muddier rocks and less diverse, highly Ceratopsisdominated clusters in the predominantly carbonate members. An exception to this generalization is found in the limestones of the Strodes Creek Member of the Lexington Limestone which has the highest ostracode diversity. However, the Strodes Creek is found entirely within the confines of the muddy Millersburg Member of the Lexington and is believed to represent a similar environment. Diversity differences in these ostracode associations are thought to be controlled mainly by substrate and kinetic energy level. We suggest that the associations may represent ecologically controlled ostracode assemblages.
\end{abstract}

' West Virginia University, Morgantown, W. Va.

\section{INTRODUCTION}

This paper is one of a series describing various elements of the Ordovician fauna of Kentucky; it is based upon collections made during the course of a program to map the geology of the State, conducted by the U.S. Geological Survey (USGS) in cooperation with the Kentucky Geological Survey. The collections were not made specifically for ostracodes but for megafossils such as brachiopods and, especially, silicified pelecypods; the ostracodes, therefore, are byproducts and may represent biased samples. Many of the specimens are silicified and were picked from residues after the limestone had been dissolved by hydrochloric or acetic acid. For all collections, 25 pounds were dissolved in acetic acid. This process may also have introduced a bias, as in some collections the ostracodes are represented by phosphatic steinkerns although the megafossils are silicified. This suggests that in some collections ostracodes may have been present but were not replaced by silica, and hence are not recorded. Some specimens are calcareous and were picked from samples of washed shale; a few were extracted from bioclastic limestone with a vibrograver and a needle. In all, 73 collections from 22 localities yielded the more than 10,000 ostracode specimens that formed the basis of this paper. Although the samples may be biased, as indicated above, and although further collecting would probably add more taxa than are described here, we believe that the number of collections studied is sufficient to give a fairly accurate picture of the character of the ostracode fauna of the Lexington Limestone and lower part of the Clays Ferry Formation.

In addition to these recent collections by members of the U.S. Geological Survey, the type collection in the U.S. National Museum of Natural History contains many specimens described from the Ordovician of Kentucky between 1890 and 1920. Not all the taxa represented by these specimens have been found in our collections; however, we have refigured the types where 
available and pertinent because many of the original illustrations are line drawings that do not represent the described taxon accurately. As many of the early species have later been made the type species of genera, we hope that these figures will help to clarify the concept of some of these taxa and will give a more comprehensive view of the ostracodes of the Lexington Limestone and lower part of the Clays Ferry Formation.

The more recent collections were mostly made from measured sections described by Cressman (1973) and Pojeta (1979). The localities of these collections are shown on figure 1 . Locality data for the older collections are usually generalized, and the stratigraphic terminology has changed as a result of recent work; however, we can identify most of the horizons from which the specimens were obtained.

\section{ACKNOWLEDGMENTS}

We thank Frederick J. Collier, of the U.S. National Museum of Natural History; Joseph H. Peck, of the Museum of Paleontology, University of California, Berkeley; and Murray J. Copeland, of the Geological Survey of Canada, for permission to borrow and photograph type specimens. In addition, thanks are hereby extended to the staff at West Virginia University, whose help was indispensable. Robert Wallace and Ronald Gervason, in particular, of the Department of Geology and Geography, helped in measuring the specimens and in preparing the statistical analysis.

\section{PREVIOUS WORK}

The highly fossiliferous Ordovician strata of Cincinnati, Ohio, and adjacent parts of Kentucky attracted some of the first American paleontologists; consequently, many of the more common genera and species of this area were described before the end of the 19th century. Emmons (1855, p. 218-219) included ostracodes from this region as "characteristic American fossils" in his textbook on American geology, and S. A. Miller, in a series of papers from 1874 to 1897 (see Bassler and Kellett, 1934, p. 126, for complete list), described or discussed ostracodes together with other elements of the fauna. Most of the species were from the Cincinnatian Provincial Series and represent horizons younger than those discussed in this paper, but many of the genera for which they have become the type species also occur in older rocks; for example, Beyrichia ciliata Emmons, 1855, and Beyrichia chambersi Miller, 1874, the type species of Ctenobolbina Ulrich, 1890, and Ceratopsis Ulrich, 1894, respectively, are from the Kope Formation, but representatives of these genera are common in the underlying Lexington Limestone.
In 1879, E. O. Ulrich described four species from the vicinity of Covington, Ky., of which two (Leperditia crepiformis and Beyrichia persulcata) appear to have come from the Point Pleasant Tongue of the Clays Ferry Formation and the other two (Leperditia unicornis and $L$. bivertex) probably came from either the Point Pleasant or the Kope Formation (Edenian). Later, Ulrich (1890) described additional species from the Ordovician of Kentucky, of which four (Primitia nitida, P.? sculptilis, $P$. centralis, $P$. perminima) are palaecopids from beds that would now be considered part of the Lexington Limestone ( $P$. nitida and P.? sculptilis) or from either the Point Pleasant or the lowermost part of the Kope ( $P$. centralis and $P$. perminima). In 1894, Ulrich (1897) named one species, Ceratopsis intermedia, the types of which come from the Point Pleasant. Bassler and Kellett (1934, p. 52) listed 14 species of ostracodes from the "Trenton," or Middle Ordovician, of Kentucky, of which half are leperditicopids and are not discussed in this paper.

Little detailed taxonomic work has been published on the Ordovician ostracodes from Kentucky since the beginning of the century, although the generic assignments of many species have been changed. Eleven genera have type species from the upper Middle and lowermost Upper Ordovician (Edenian) rocks of the State and immediately adjacent parts of Ohio, but of these, five are from the High Bridge Group, which underlies the Lexington Limestone and is not within the scope of this report. Two of the remaining six genera, Laccoprimitia Ulrich and Bassler, 1923 (type species, Primitia centralis Ulrich, 1890), and Pseudulrichia Schmidt, 1941 (type species, Leperditia bivertex Ulrich, 1879), are based on specimens from either the Point Pleasant Tongue of the Clays Ferry Formation or the Kope Formation at Covington, Ky.; the other four genera, Ceratopsis Ulrich, 1894, Ctenobolbina Ulrich, 1890, Jonesella Ulrich, 1890, and Warthinia Spivey, 1939, are based on species from the Edenian Kope Formation at Cincinnati, Ohio, or Covington, Ky., but also occur in the Lexington and the Clays Ferry. Warshauer (1975) redescribed the type species of Ceratopsis, $C$. chambersi (Miller, 1874) from the Kope Formation of southwestern Ohio and northern Kentucky.

The massive character of much of the Lexington Limestone probably accounts for the small number of species described from it previously, as the more ornate ostracodes are extremely difficult to extract unbroken from this type of rock, whereas the calcareous shales of the Clays Ferry and Kope Formations are more suitable for mechanical preparation. When the U.S. Geological Survey in cooperation with the Kentucky Geological Survey began mapping the entire State in 1961, many 


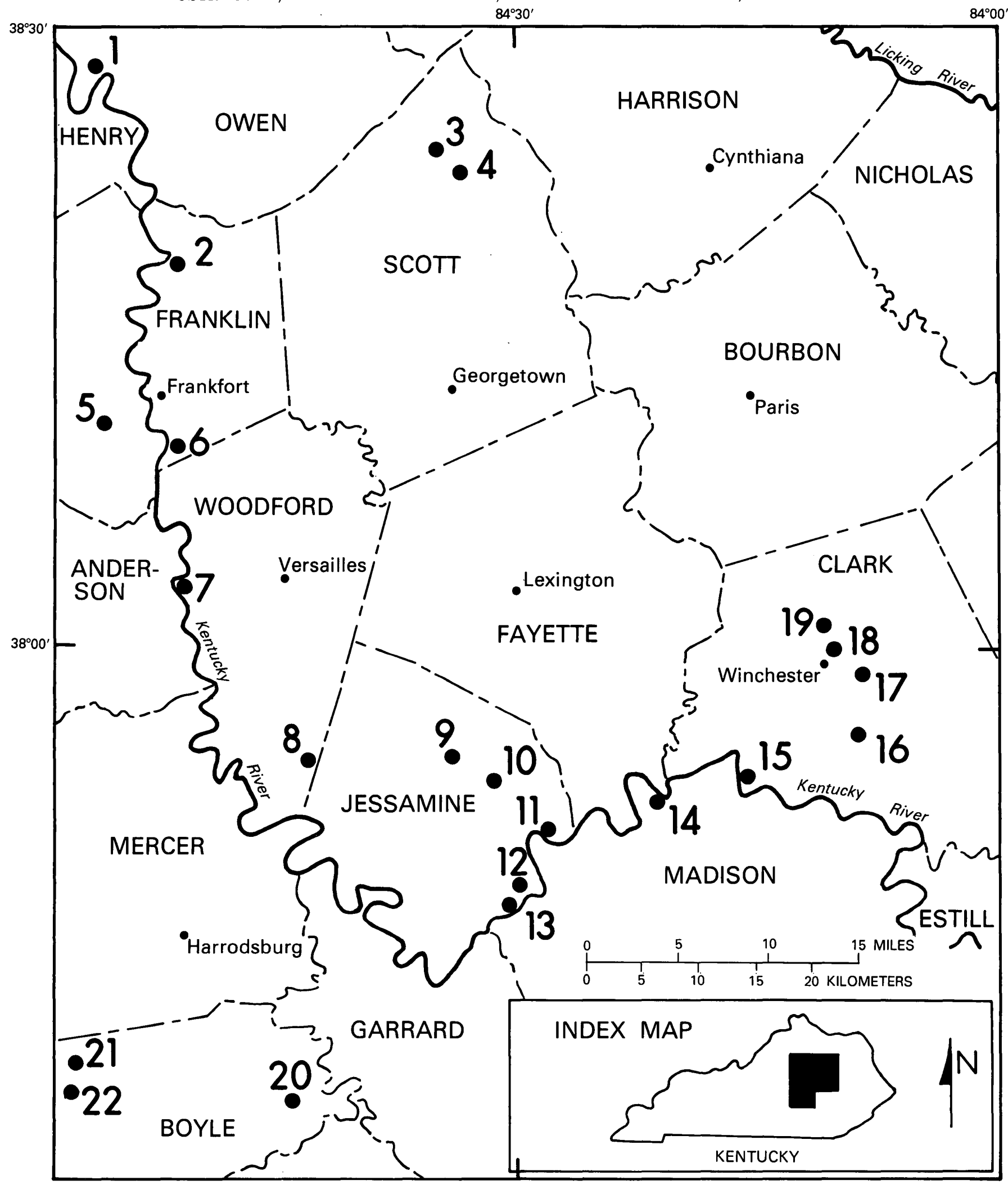

FIGURE 1.-Generalized map of central Kentucky, by county, showing Ordovician ostracode localities (numbered circles) used in this study. Index map shows location of study area (shaded). 
samples of Lexington Limestone were prepared chemically for the first time, and the residues from these samples contained many silicified ostracodes. Berdan (1970) gave a preliminary report on the character of the ostracode assemblages in the Lexington, and Cressman (1973) published lists of the ostracodes showing their stratigraphic occurrence. This paper provides descriptions and illustrations of the palaeocopid and podocopid ostracodes from these collections for the first time.

\section{AGE AND CORRELATION}

Pojeta (1979) summarized the evidence for the age of the Lexington Limestone and Clays Ferry Formation and concluded that the Lexington ranges in age from Kirkfieldian to Edenian (late Middle Ordovician to early Late Ordovician) and that the Clays Ferry ranges from Shermanian to Edenian (late Middle Ordovician to early Late Ordovician). In places, the Point Pleasant Tongue of the Clays Ferry crosses the Middle-Late Ordovician boundary (Pojeta, 1979; Sweet, 1979). The lower part of the Lexington (Curdsville Limestone Member) has been correlated with the upper part (Ion Dolomite Member) of the Decorah Formation of Minnesota by Cooper (1956), using brachiopods, and by Sweet and Bergstrom (1976), using conodonts, although Karklins (oral commun., 1977), on the basis of bryozoans, considers that Decorah equivalents also may be included in the younger Grier Limestone Member of the Lexington. Sweet and Bergstrom (1976, p. 133) correlated the remainder of the Lexington and the lower part of the Point Pleasant Tongue with the "Cummingsville Formation" and the upper part of the Point Pleasant with the "Prosser Formation," both of the "Galena Group" in Minnesota. In addition, Sweet and Bergstrom (1976, p. 133) indicated correlation of the Lexington-Point Pleasant with the upper part of the "Corbin Ranch" and lower part of the "Viola Formations" of south-central Oklahoma; the "Hermitage, Cannon, Bigby," and lower part of the "Catheys Formations" of central Tennessee; the "Kings Falls, Sugar River," and lower part of the "Denley Formations" of New York; and the upper part of the "Nealmont, Salona, and Coburn Formations" of central Pennsylvania.

The ostracode faunas from the formations correlated with the Lexington Limestone and Clays Ferry Formation in Oklahoma, Tennessee, New York, and Pennsylvania are poorly known. Harris (1957, p. 272) listed eight species that he had described from the Corbin Ranch Formation of south-central Oklahoma; five of these are species of one genus, Leperditella Ulrich, 1894, and none of the eight species has been found in Kentucky. As far as we know, no ostracodes have been described from the Viola Limestone. In Tennessee,
Bassler and Kellett (1934, p. 52) listed 16 species from the Hermitage, Cannon, and Catheys Limestones, of which nine are leperditicopids and beyond the scope of this report. Of the remaining seven, two, Ceratopsis intermedia Ulrich, 1894, and Phelobythocypris cylindrica (Hall, 1871), are abundant throughout the Lexington Limestone and Clays Ferry Formation; two, Ctenobolbina ciliata parva Kirk, 1928, and Bolbopisthia reticulata (Kirk, 1928), are closely related to forms from the Lexington and the Clays Ferry; three, Bolbopisthia progressa (Kirk, 1928), Eurychilina reticulata Ulrich, 1889, and Glymmatobolbina praenuntia (Ulrich and Bassler, 1908) have not yet been found in Kentucky. The ostracodes from formations equivalent to the Lexington and the Clays Ferry in New York are in need of revision. Bassler and Kellett (1934, p. 51-53) listed taxa from the "Trenton" and "Eden" of New York; most of these were described more than 50 years ago and have not been studied since. As yet, no ostracodes have been reported from beds correlated with the Lexington and the Clays Ferry from Pennsylvania.

In contrast, ostracodes from the Decorah, "Cummingsville, and Prosser" of Minnesota and adjacent States are relatively well known. Ulrich (1894, see 1897) described many of the ostracodes from the Decorah ("Trenton shales") and the "Cummingsville" and the "Prosser" ("Galena shales"), and further descriptions of Decorah ostracodes have been provided by Kay (1934, 1940) and Swain, Cornell, and Hansen (1961). Copeland $(1965,1971,1974,1977 \mathrm{a}, \mathrm{b})$ has documented the occurrence of elements of the Decorah ostracode assemblage in areas of Canada as widely separated as the southeastern District of Franklin, southwestern District of Mackenzie, western Newfoundland, and southern Ontario. Under the circumstances, it is unfortunate that we have only four collections that yielded ostracodes from the Curdsville Limestone Member of the Lexington Limestone, the lowest member of the formation and presumably the equivalent of the Decorah. Three of these collections have yielded only a few species, most of which are long ranging, but one (USGS colln. 5083-CO), from the lowest foot of the Curdsville, contains 10 taxa that are similar to or are the same as those in the Decorah fauna. These include Eurychilina subradiata Ulrich, 1890, Hesperidella? initialis (Ulrich, 1894), Dicranella? sp. aff. D.? marginata Ulrich, 1894, and an "Aparchites" sp. belonging to the group of "Aparchites" fimbriatus (Ulrich, 1892). None of these 10 taxa has been found in overlying members of the Lexington Limestone or in the Clays Ferry Formation.

Ostracodes from the "Cummingsville" and the "Prosser" have not been as thoroughly studied as those from the Decorah. However, Bassler and Kellett (1934, p. 51) listed 16 species from the "Prosser," which at that time 
would have included the "Cummingsville." An emended and updated version of their list follows: Bollia subaequata Ulrich, 1894, Bollia unguloidea Ulrich, 1894, Byrsolopsina? uphami (Ulrich, 1894), Ceratopsis chambersi (Miller, 1874), Ctenobolbina? obliqua Ulrich, 1894, Eurychilina ventrosa Ulrich, 1894, Halliella labiosa Ulrich, 1894, Jonesella? obscura Ulrich, 1894, Macrocyproides trentonensis (Ulrich, 1894), Maratia micula (Ulrich, 1894), Phelobythocypris cylindrica (Hall, 1871), Punctaparchites rugosus (Jones, 1858), Punctaparchites rugosus arctus (Ulrich, 1894), Schmidtella affinis Ulrich, 1894, Schmidtella incompta subaequalis Ulrich, 1894, Tetradella lunatifera Ulrich, 1894. The presence of Ceratopsis chambersi in the "Prosser" has not been verified; Ulrich (1894, see 1897, p. 677) mentioned that he had not found it in any part of the "Galena." In addition to the taxa listed above, a collection from the "Prosser" south of Fountain, Minn. (USGS 4029-CO), contains Eoaquapulex socialis (Levinson, 1961), Brevidorsa sp., Krausella sp., and Macrocyproides sp. Although the 19 taxa cited here probably represent only a small part of the "Cummingsville" and the "Prosser" ostracode fauna, they also probably represent the more abundant species. There are few taxa in common with the post-Curdsville ostracode assemblages of the Lexington Limestone and the Clays Ferry Formation.

The ostracodes from the Lexington Limestone and the Clays Ferry Formation described in this paper are listed in table 1; the members and collections in which they occur are shown in approximate stratigraphic order. Because of the intertonguing of facies in the Lexington, the exact stratigraphic position of the taxa cannot be shown on a table of this type. However, it is apparent that three species, Warthinia nodosa (Ulrich, 1890), Ceratopsis asymmetrica n. sp., and Phelobythocypris cylindrica (Hall, 1871) range throughout the entire interval under consideration, and several others range from the Grier Limestone Member through the highest beds.

To summarize, ostracodes from the Curdsville Limestone Member are similar to those of the Decorah Formation of Minnesota and Iowa, but those from younger members of the Lexington and from the Clays Ferry do. not greatly resemble ostracodes from equivalent formations in Minnesota. In particular, two of the more distinctive Middle and Late Ordovician genera, Eurychilina Ulrich, 1889, and Tetradella Ulrich, 1890, are lacking in the post-Curdsville Lexington, although, as noted by Ulrich $(1890$, p. 114), Tetradella is present both above and below this interval in Kentucky. Cressman (1973, p. 55-57, pl. 11) suggested the presence of an embayment of deeper water between central Kentucky and Minnesota during Lex- ington time; whether this embayment or some other ecologic factor affected the ostracodes is not known. As 'might be expected, the post-Curdsville ostracode assemblage is most similar to that described from the Cannon and Catheys Limestones from nearby central Tennessee.

\section{PALEOECOLOGY}

Stratigraphic framework.-Contemporary stratigraphic analysis of the Lexington Limestone has been dealt with by several authors (Black, Cressman, and MacQuown, 1965; Cressman, 1973; Black and Cuppels, 1973; Pojeta, 1979) who have divided the unit into 11 lithostratigraphically defined members. As shown by Cressman (1973), the members formed under the myriad of different environmental conditions associated with carbonate-bank deposition and now form a complex facies mosaic. Ostracodes have been recovered from eight of the members, representing a wide spectrum of Lexington lithologies and, therefore, a correspondingly wide range of depositional environments. In addition, the lower part of the Clays Ferry Formation, the only part included in this study, has been shown to be a temporal equivalent of the upper part of the Lexington Limestone (Weir and Greene, 1965; Cressman, 1973; Pojeta, 1979) and thus adds to the environmental heterogeneity of the studied interval. This lower part of the Clays Ferry is distinguished as the Point Pleasant Tongue in northern Kentucky (Swadley, Luft, and Gibbons, 1975). A summary of the lithologies for each of the stratigraphic units containing ostracodes can be found in table 2.

Method of analysis. - Direct analysis of the speciesdistribution data was deemed impossible because of variable preservation, many specimens being either phosphatic steinkerns or badly fragmented or crushed, which severely hindered sample comparisons. This problem was mitigated, however, by use of the generic-level data matrix, as all specimens could confidently be placed in a category of this breadth. Of the 73 USGS collections studied, only 44 contained a sufficient number of specimens to warrant quantitative analysis. Multivariate numerical analysis of the quantitative generic-level ostracode data (relative percentages of 27 genera of ostracodes in 44 collections) was then initiated by use of Q-mode cluster analysis. This method of analysis was chosen as it is nonparametric; that is, the samples do not have to be random or normally distributed, statistical criteria not met by the present collections. Additionally, cluster analysis has been fairly commonly used in geologic research (Kaesler, 1966; Maddocks, 1966; Bonham-Carter, 1967; Valentine and Peddicord, 1967; Mello and Buzas, 1968; Hazel, 1970, 1971; MacDonald, 1975; Smosna and Warshauer, 1978; 
TABLE 1. -Ostracode taxa described in this paper and the

[Members of the Lexington Limestone are in approximate stratigraphic order. Collection numbers followed by -CO are USGS collections;

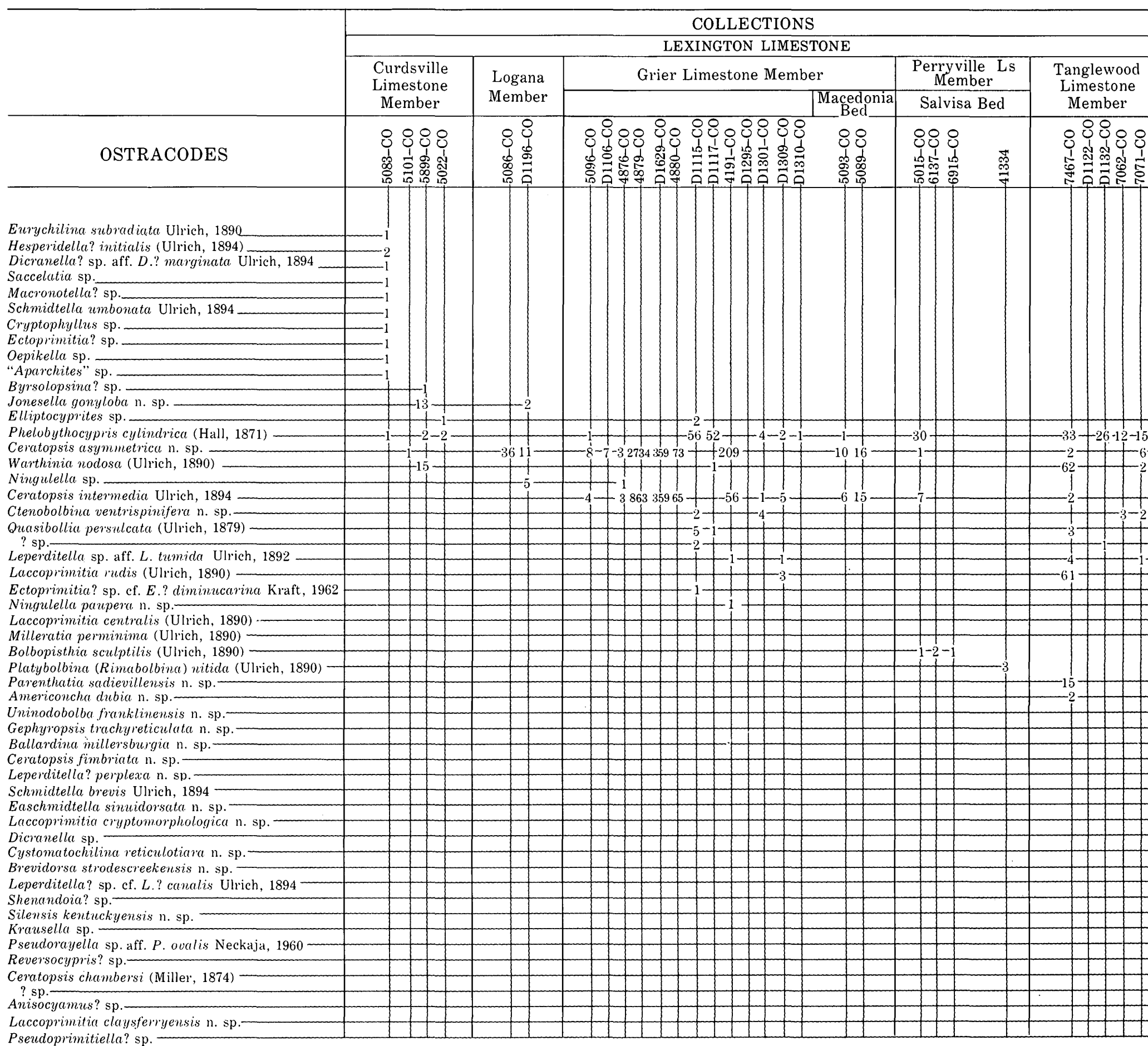


stratigraphic units and the collections in which they occur

all others are USNM collections. Numbers opposite taxa represent the number of specimens recovered from each collection]

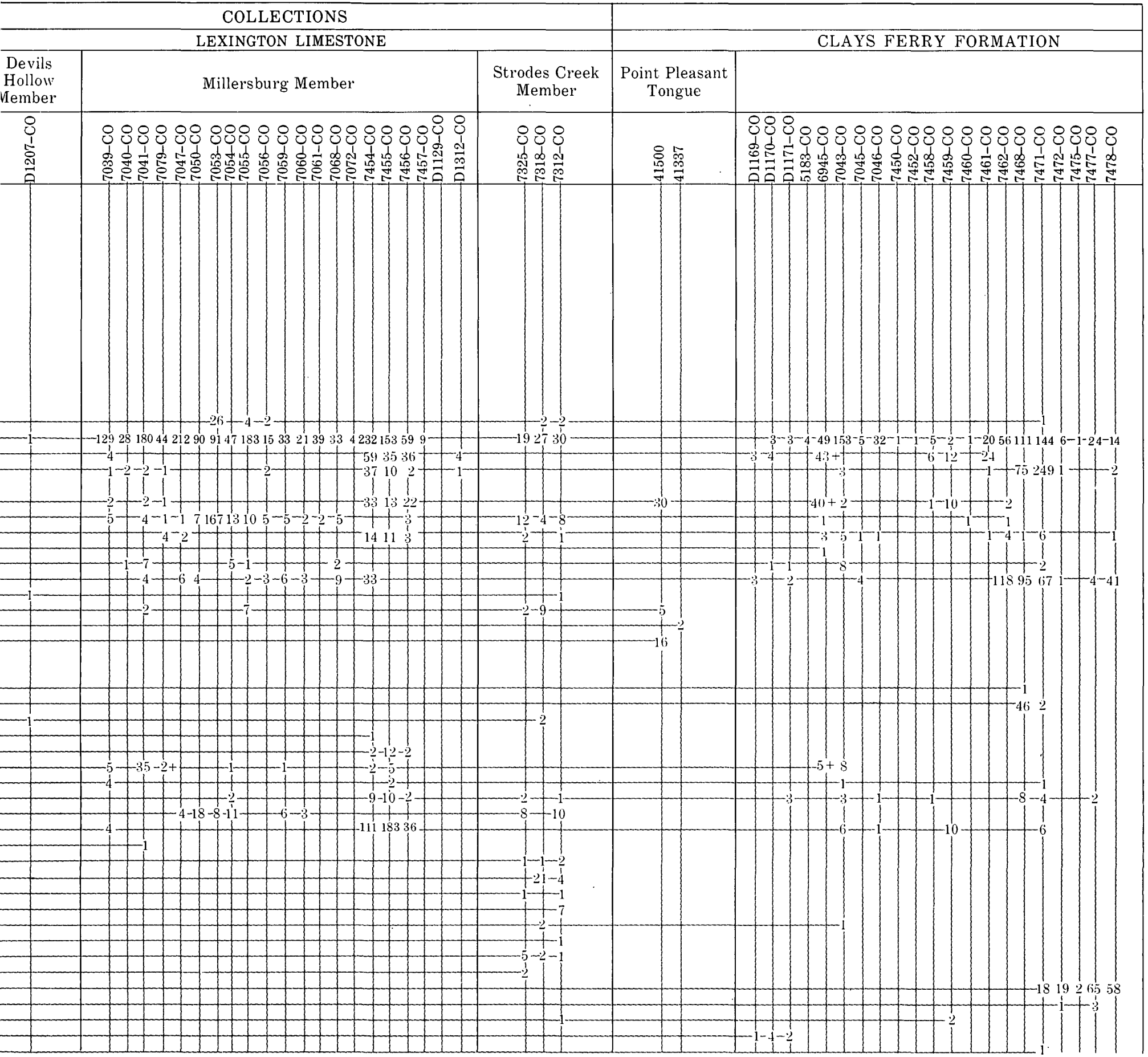


TABLE 2. - Lithologies of the ostracode-bearing stratigraphic units included in this study

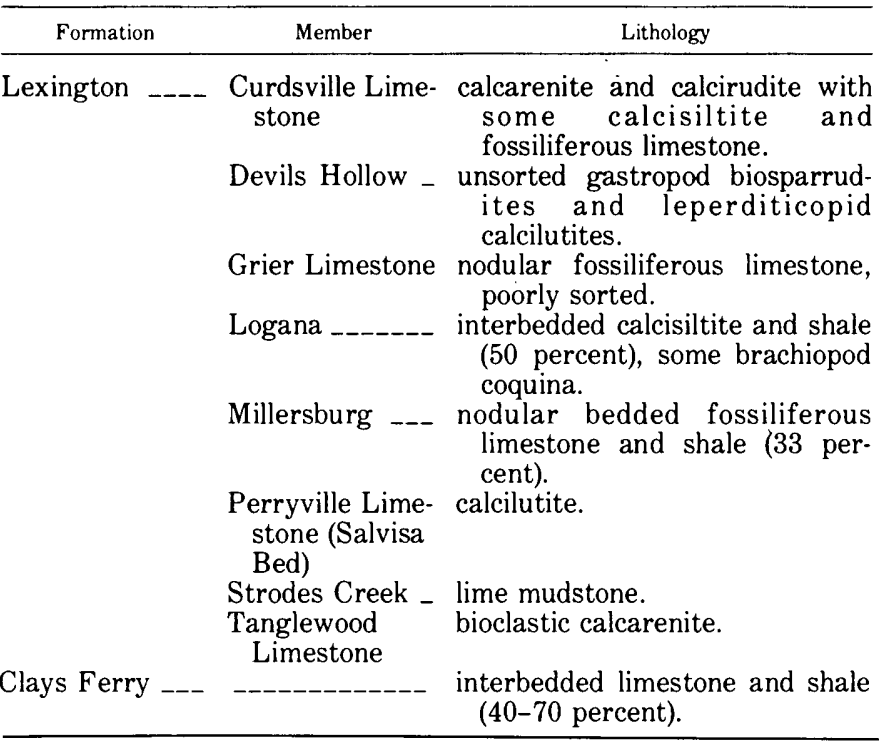

Warshauer and Smosna, 1977) and is generally easy to understand (Sneath and Sokal, 1973).

Similarities were calculated by use of Sorensen's coefficient, a quantified similarity coefficient previously used for ecologic and paleoecologic studies (Bray and Curtis, 1957; Park, 1968, 1974; Gevirtz and others, 1971; Gevirtz, 19742) that lacks the problems inherent with distance functions (Sepkoski, 1974). Below is an example, taken from Gevirtz $\left(1974^{2}\right)$, of the calculation of Sorensen's coefficient using an arbitrary data set for two samples. $X^{i}$ and $X^{j}$ are values (percentages) for the variables in the two samples being compared. $W$ is the summation of the minimum values:

Computation of $2 W /(A+B)$, Sorensen's coefficient

\begin{tabular}{|c|c|c|c|}
\hline & \multicolumn{2}{|c|}{$X_{i} \quad X_{j}$} & \multirow[b]{2}{*}{$W=5+1+10+4+2+3+25+5$} \\
\hline & & 5 & \\
\hline & 5 & 1 & $2 W=130.0$ \\
\hline \multirow[t]{2}{*}{$W=\Sigma \min \left(X_{i} X_{j}\right)$} & 25 & 10 & \\
\hline & & 4 & $A=100.0$ \\
\hline$A=\sum X_{i}$ & 2 & 20 & $B=100.0$ \\
\hline \multirow[t]{3}{*}{$B=\sum X_{j}$} & 30 & 25 & \\
\hline & 5 & 10 & $2 W / A+B=130 / 200$ or 0.65 , Similar. \\
\hline & $\begin{array}{r}10 \\
5\end{array}$ & $\begin{array}{r}5 \\
10\end{array}$ & $1.00-0.65=0.35$ \\
\hline
\end{tabular}

The data set was unstandardized in order to weigh the variables by magnitude. This step was felt to be imperative, as magnitude is most certainly a direct result

${ }^{2}$ Gevirtz, J. L., 1974, Describing the natural environment for capability assessment, in An approach to natural environment analysis: Houston, Tex., Rice Center for Community Design and Research, unpublished report, p. 20-45 of the environmental conditions that we wish to delineate. Clustering was accomplished by use of the unweighed pair-group method with arithmetic averages, as this algorithm generally engenders the least distortion to the resulting phenogram (Farris, 1969; Hazel, 1970).

Clusters generated by the aforementioned method were then characterized by the construction of average collections for each of the clusters (fig. 2-11). Additionally, constancy $(C)$ and fidelity $(F)$ values were calculated for each of the variables in each of the clusters.

Constancy: $C=$ percent occurrence of a variable within a cluster.

Fidelity:

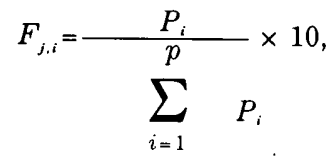

Where: $j=$ the variable $(j=a, b, c, \ldots, n)$;

$$
\begin{gathered}
P_{i}=\text { the percent occurrence of a variable within cluster } i \\
(i=1,2,3, \ldots, p) .
\end{gathered}
$$

Constancy and fidelity are measurements that originally were devised by Hazel $(1970,1977)$ for biostratigraphic studies but that subsequently have been demonstrated to be equally useful in paleoecology (Warshauer and Smosna, 1977). Simply stated, constancy is the percent occurrence of a variable in a cluster, and fidelity is a measure of how restricted a variable is to a cluster.

Simple generic diversity and compound generic diversity, the Shannon-Weaver diversity function (Pielou, $1966 \mathrm{a}, \mathrm{b})$, were also calculated for each of the collections.

\section{Generic Diversity}

Simple:

$$
G=\text { number of genera in sample. }
$$

Compound:

$$
H(G)=-\sum_{i=1}^{G} p_{i} \operatorname{In} p_{i},
$$

where $i=$ the proportion of the $i$ th genus.

Mean values for both diversity measures were then calculated to help characterize the clusters, as trends in 


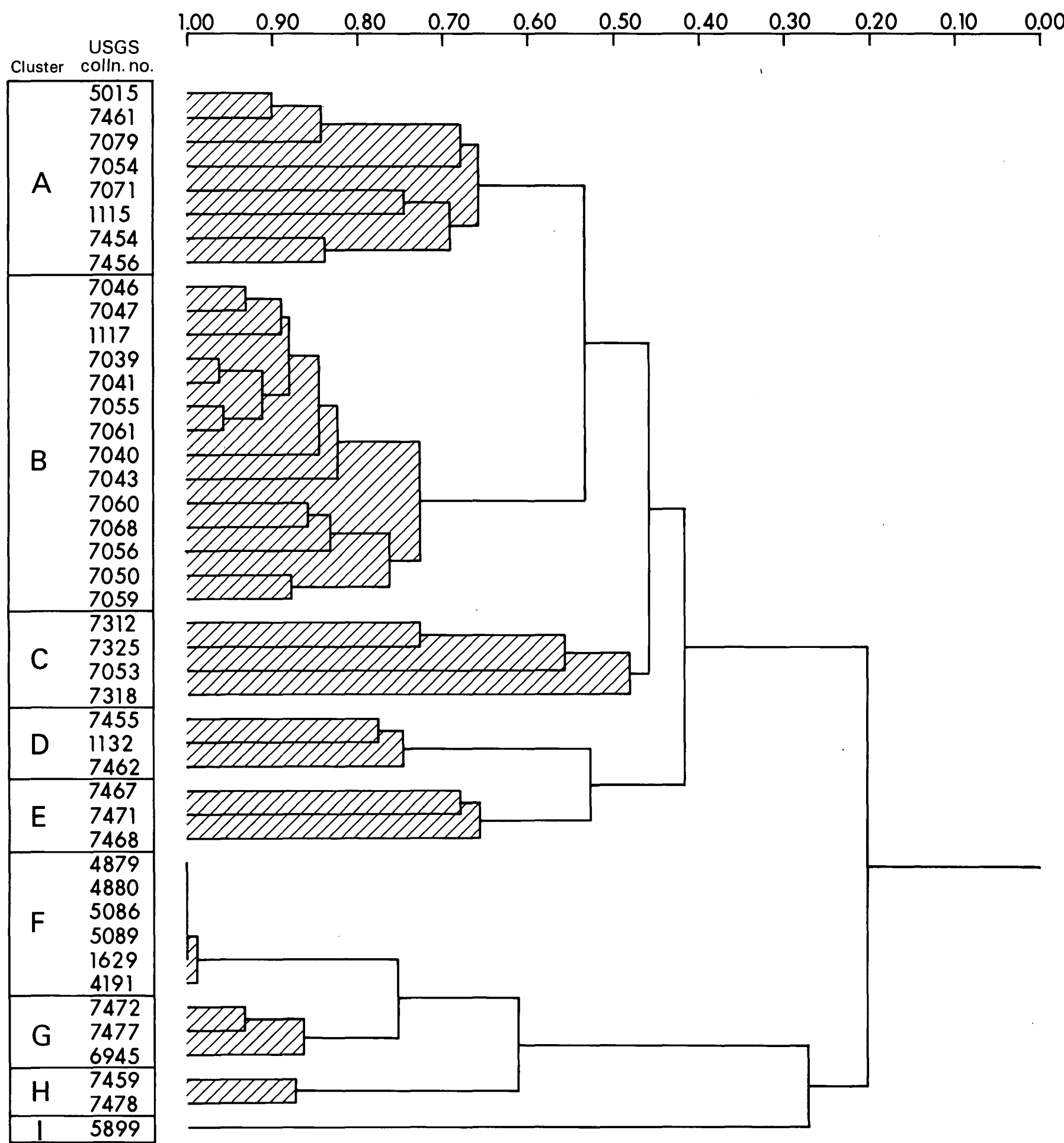

FIgURE 2. - Q-mode dendrogram showing the relationship of the 44 quantitatively defined collections to one another. The four-digit numbers to the left of the dendrogram are USGS collection numbers and are all followed by $-\mathrm{CO}$ (for example, 5015-CO). All collection numbers beginning with 1 are preceded by D (for example D1115-CO). 


\begin{tabular}{|l|l|l|l|l|l|l|}
\hline 1 & 1 & 1 & 1 & 1 & \\
0 & & & & & \\
50 & & & &
\end{tabular}

1. Phelobythocypris

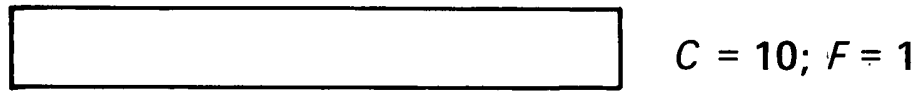

2. Ceratopsis

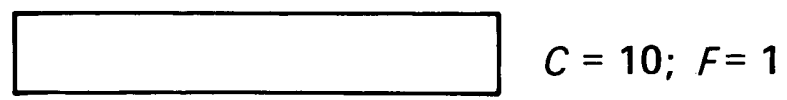

3. Laccoprimitia

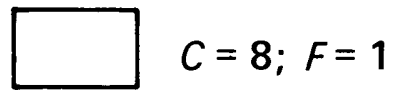

4. Schmidtella

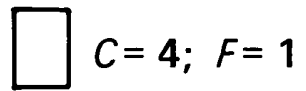

5. Ctenobolbina

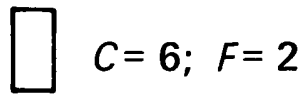

6. Warthinia

$\square C=6 ; F=2$

7. Quasibollia

$C=6 ; F=2$

8. Leperditella

$C=4 ; F=1$

9. Others

$$
\begin{array}{ll}
N=8 & \bar{X} G=6.250 \\
\bar{X} H(G)=1.205 &
\end{array}
$$

FigURE 3. - Histogram of common genera in cluster A (see fig. 2). $C$, constancy; $F$, fidelity; $N$, number of collections in the cluster; $\bar{X} H(G)$, mean compound generic diversity; $\bar{X} G$, mean simple generic diversity.

these values have been shown to be powerful tools in both ecologic and paleoecologic studies (Buzas and Gibson, 1969; Johnson, 1970; Donahue and Rollins, 1974). Lithologic associations were then scanned in an attempt to better understand the relationship between the taxa and different rock types.

Results. - Perusal of the phenogram (fig. 2) shows that it is composed of eight fairly well-defined clusters, $\mathrm{A}-\mathrm{H}$, and one sample that is not closely related to any other, outlier I. Examination of the average collections for the clusters (figs. 3-11) disclosed several interesting rela- tionships. First, clusters A-E are strongly dominated by phelobythocyprids in combination with either Warthinia, Laccoprimitia, Ctenobolbina, or Ceratopsis. Clusters $\mathrm{F}-\mathrm{H}$, on the other hand, are strongly dominated by Ceratopsis. Second, clusters A-E are more highly diverse (both $G$ and $H(G)$ ) than are clusters $\mathrm{F}-\mathrm{H}$. Third, the lithologic associations of the clusters indicate that clusters A-E are from the predominantly muddy rocks, 75 percent of the collections in these clusters coming from shales within the Millersburg Member of the Lexington or from the Clays Ferry For- 
Average percent occurrence

\begin{tabular}{|l|l|l|l|l|l|l|}
\hline 1 & 1 & 1 & 1 & 1 \\
0 & & & & \\
50 & &
\end{tabular}

1. Phelobythocypris

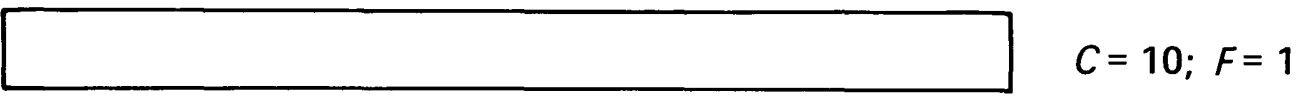

2. Laccoprimitia

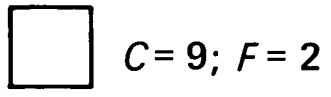

3. Ctenobolbina

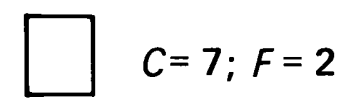

4. Ceratopsis

$$
\square C=9 ; F=1
$$

5. Schmidtella

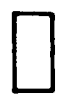

$C=4 ; F=1$

6. Leperditella

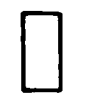

$C=6 ; F=2$

7. Warthinia

$$
\prod C=4 ; F=1
$$

\section{Others}

$$
\begin{array}{ll}
N=14 & \bar{X} G=5.786 \\
\bar{X} H(G)=0.813 &
\end{array}
$$

FiguRE 4.-Histogram of common genera in cluster B (see fig. 2). $C$, constancy; $F$, fidelity; $N$, number of collections in the cluster; $\bar{X} H(G)$, mean compound generic diversity; $\bar{X} G$, mean simple generic diversity.

mation. The few exceptional collections included in these clusters that came from the carbonate members of the Lexington, such as the Tanglewood, Grier, and Perryville Limestone Members, may represent mixing of faunas by currents or, in the fine-grained Perryville, may represent an environment similar to that of the shales. A major exception is in the most diverse of the clusters, cluster $\mathrm{C}$, as three of the four collections in that cluster are from the limy Strodes Creek Member. However, the Strodes Creek is a lime mudstone and occurs completely within the confines of the muddy Millersburg. We therefore believe that the Strodes Creek most probably represents an environment very similar to that in the Millersburg and does not really constitute an exception.
Clusters $\mathrm{F}-\mathrm{H}$, on the other hand, are from carbonate units, 73 percent of them coming from limy members of the Lexington. The remaining collections in clusters F-H were recovered from limestone layers within predominantly shale members.

Outlier I represents the only analyzed collection from the Curdsville Limestone Member and indicates a marked faunal difference between the Curdsville and the other Lexington members.

Perusal of the constancy and fidelity values shows that while constancy values are generally high, fidelity values are, for the most part, low. This indicates that very few of the genera are restricted to only one cluster.

Conclusions. - The clusters represent quantitatively defined ostracode associations that may reflect living 
Average percent occurrence

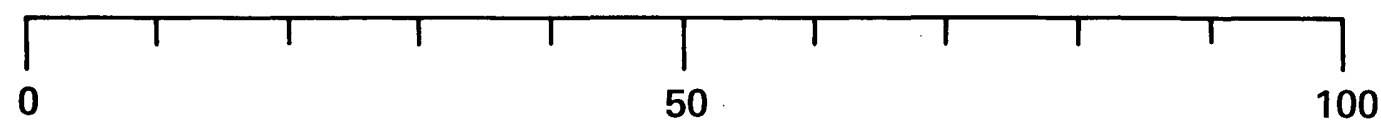

1. Phelobythocypris $\square C=10 ; F=1$

2. Ctenobolbina

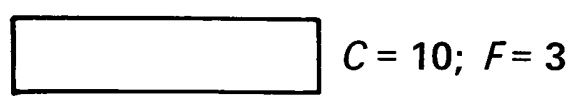

3. Schmidtella

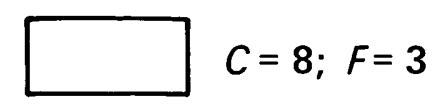

4. Brevidorsa

$C=5 ; F=10$

5. Pseudorayella

$C=8 ; F=10$

6. Ningulella

$C=5 ; F=6$

7. Ceratopsis

$C=8 ; F=1$

8. Reversocypris ? $\square C=3 ; F=10$

9. Cystomatochilina $\square C=8 ; F=10$

10. Silenis

$\prod C=3 ; F=8$

11. Quasibollia

$$
C=5 ; F=1
$$

12. Others

$$
\begin{array}{ll}
N=4 & \bar{X} G=8.250 \\
\bar{X} H(G)=1.514 &
\end{array}
$$

FIGURE 5. - Histogram of common genera in cluster C (see fig. 2). C, constancy; $F$, fidelity; $N$, number of collections in the cluster; $\bar{X} H(G)$, mean compound generic diversity; $\bar{X} G$, mean simple generic diversity. 


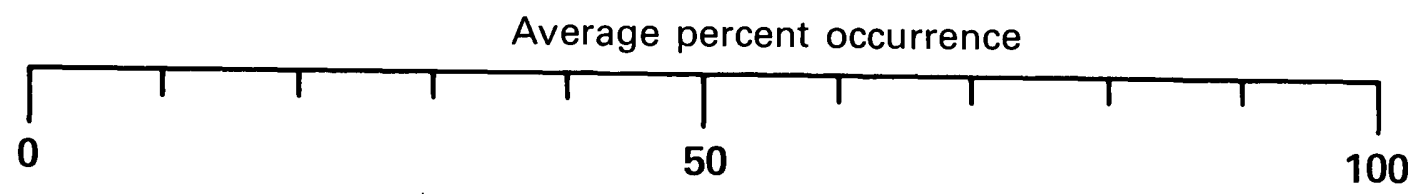

1. Laccoprimitia

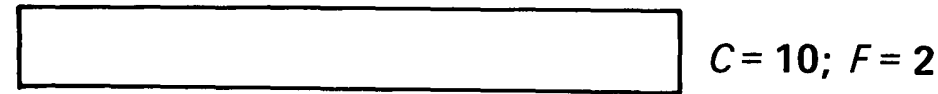

2. Phelobythocypris

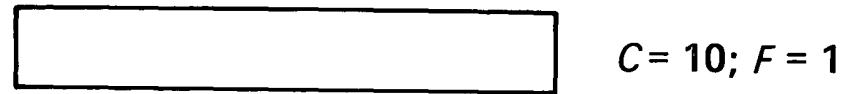

3. Ceratopsis

$C=10 ; F=1$

4. Quasibollia

$C=7 ; F=2$

5. Ballardina

$C=3 ; F=6$

6. Others

$$
\begin{array}{ll}
N=3 & \bar{X} G=5.667 \\
\bar{X} H(G)=1.026 &
\end{array}
$$

FiguRE 6. - Histogram of common genera in cluster $\mathrm{D}$ (see fig. 2). $C$, constancy; $F$, fidelity; $N$, number of collections in the cluster; $\bar{X} H(G)$, mean compound generic diversity; $\bar{X} G$, mean simple generic diversity.

assemblages. However, biases introduced into the collections due to differing modes of preservation (see introduction) may have altered the true bioassociational relationships. Tentatively, however, we interpret the clusters to be relicts of ecologically controlled assemblages. It will suffice to say that clusters A-E represent ostracode assemblages of high to moderate diversity that preferred a muddy substrate and its corresponding low kinetic energy. Clusters $\mathrm{F}-\mathrm{H}$, on the other hand, represent ostracode assemblages of low to moderate diversity that preferred carbonate substrates and moderate to high kinetic energy.

As leperditicopid ostracodes are not discussed in this paper, one probable ostracode assemblage was not included in the above cluster analysis. The calcilutite of the Devils Hollow Member of the Lexington was noted by Cressman (1973, p. 41) as containing ostracodes, primarily leperditicopids, as shown on table 2. Other Devils Hollow ostracodes (table 1) are represented by only two taxa. The Salvisa Bed of the Perryville is also calcilutite and also contains leperditicopids, but few other forms. These assemblages dominated by leperditicopids may represent a very shallow lagoonal community.

In general, the specific composition of the mosaic of ostracode assemblages in the members of the Lexington Limestone changes only gradually upward through the lower part of the Clays Ferry Formation; some species range throughout this stratigraphic interval and continue into the overlying Kope Formation. The most distinct ostracode assemblage is that in the lowermost part of the Curdsville Limestone Member, which has only one species that also occurs in the assemblages in the overlying beds. Cressman (1973, p. 14) considered that much of the lower part of the Curdsville was deposited in a high-energy environment; however, the Tanglewood Limestone Member was also deposited in a high-energy environment (Cressman, 1973, p. 31) but has only one species in common with the lower part of the Curdsville. The differences between the ostracode 
Average percent occurrence

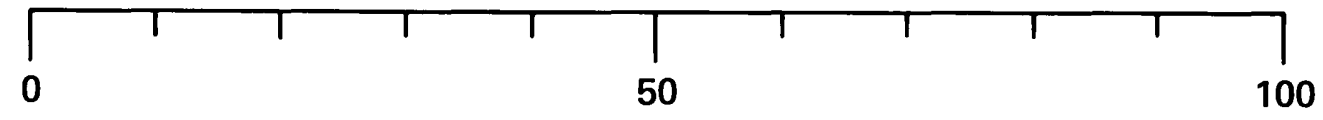

1. Warthinia

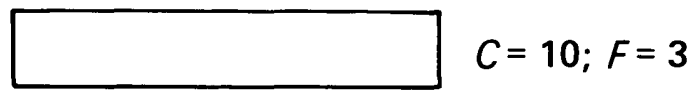

2. Phelobythocypris

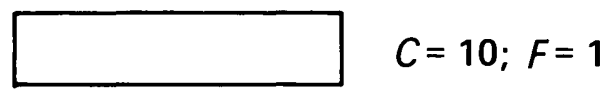

3. Laccoprimitia

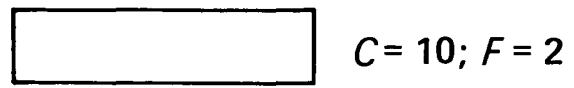

4. Americoncha

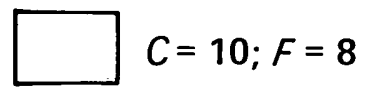

5. Parenthatia

$C=7 ; F=10$

6. Ceratopsis

$\prod C=7 ; F=1$

7. Leperditella

\C=7;F=2

8. Quasibollia

\C=10; $F=3$

9. Schmidtella

$C=7 ; F=2$

10. Others

$N=3$

$\bar{X} H(G)=1.446$

$\bar{X} \mathbf{G}=\mathbf{8 . 0}$

FIGURE 7. - Histogram of common genera in cluster $\mathrm{E}$ (see fig. 2). $C$, constancy; $F$, fidelity; $N$, number of collections in the cluster; $\bar{X} H(G)$, mean compound generic diversity; $\bar{X} G$, mean simple generic diversity.

assemblage of the lower part of the Curdsville and the assemblages of younger members are therefore probably due to age rather than to depositional environment.

\section{LIST OF LOCALITIES}

All the following fossil localities are in central Kentucky and are shown in figure 1. Millimeter coordinates given as used by Pojeta (1979, p. 19).
Locality 1. -Gratz A, 1.7 mile east-southeast of Gratz, on Kentucky Route 355, Gratz 7.5-minute quadrangle, Owen County (section 62 of Cressman, 1973). Coordinates: base of section at $280 \mathrm{~mm}$ east, $416 \mathrm{~mm}$ north. Five collections were made in the Lexington Limestone: USGS D1295-CO, $40 \mathrm{ft}$ below the top of the Grier Limestone Member; USGS D1301-CO, $20 \mathrm{ft}$ below the top of the Grier Limestone Member; USGS D1309-CO, $8 \mathrm{ft}$ below the top of the upper tongue of the Grier Limestone Member; USGS D1310-CO, $2 \mathrm{ft}$ below the 
Average percent occurrence

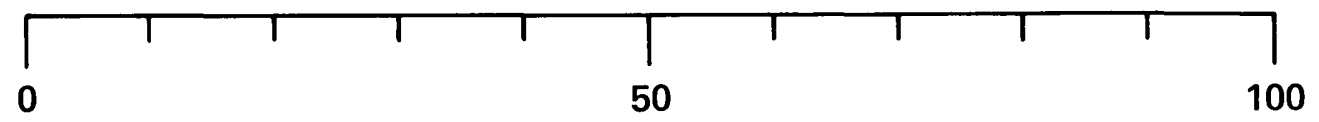

\section{Ceratopsis}

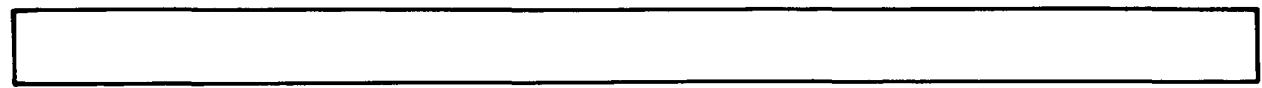

$C=10 ; F=1$

\section{Others}

$$
\begin{array}{ll}
N=6 & \bar{X} G=1.333 \\
\bar{X} H(G)=0.012 &
\end{array}
$$

FiguRE 8. - Histogram of common genera in cluster F (see fig. 2). $C$, constancy; $F$, fidelity; $N$, number of collections in the cluster; $\bar{X} H(G)$, mean compound generic diversity; $\bar{X} G$, mean simple generic diversity.

Average percent occurrence

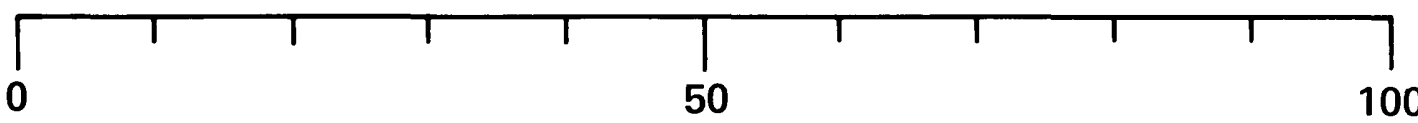

1. Ceratopsis

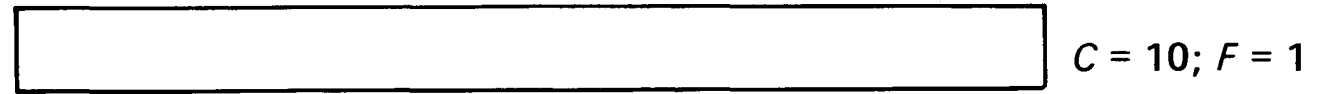

2. Phelobythocypris

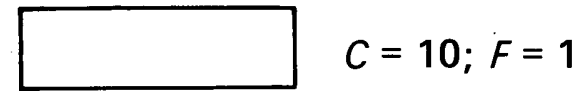

3. Laccoprimitia

$C=7 ; F=1$

4. Schmidtel/a

$C=3 ; F=1$

5. Others

$$
\begin{array}{ll}
N=3 & \bar{X} G=4 \\
\bar{X} H(G)=0.696 &
\end{array}
$$

FIGURE 9. - Histogram of common genera in cluster G (see fig. 2). $C$, constancy; $F$, fidelity; $N$, number of collections in the cluster; $\bar{X} H(G)$, mean compound generic diversity; $\bar{X} G$, mean simple generic diversity.

top of the upper tongue of the Grier Limestone Member; USGS D1312-CO, from the Millersburg Member, $6 \mathrm{ft}$ below the Lexington-Clays Ferry contact.

Locality 2. - Switzer A, roadcuts on Kentucky Route 35, south side of Elkhorn crossing; outcrops are continuous along road for 0.8 mile; Switzer 7.5-minute Quadrangle, Franklin County (section 61 of Cressman,
1973). Coordinates: base of section at $115 \mathrm{~mm}$ east, 281 $\mathrm{mm}$ north. Six collections were made in the Lexington Limestone. All the footage notations refer to the distances that the collections were made above the base of the section: USGS D1106-CO, Grier Limestone Member, $7 \mathrm{ft}$; USGS D1115-CO, Grier Limestone Member, $65 \mathrm{ft}$; USGS D1117-CO, Grier Limestone 
Average percent occurrence

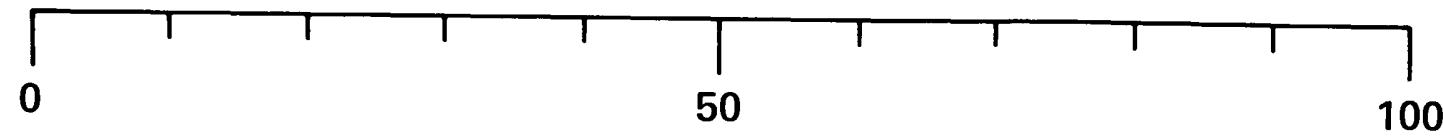

1. Ceratopsis

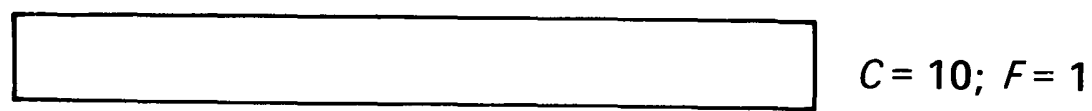

2. Laccoprimitia

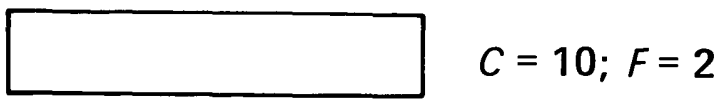

3. Phelobythocypris

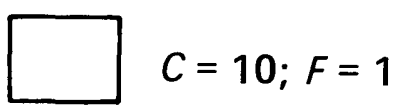

4. Anisocyamus?

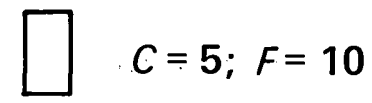

5. Others

$$
\begin{array}{ll}
N=2 & \bar{X} G=4.5 \\
\bar{X} H(G)=1.012 &
\end{array}
$$

Figure 10. - Histogram of common genera in cluster $\mathrm{H}$ (see fig. 2). $C$, constancy; $F$, fidelity; $N$, number of collections in the cluster; $\bar{X} H(G)$, mean compound generic diversity; $\bar{X} G$, mean simple generic diversity.

Member, $75 \mathrm{ft}$; USGS D1122-CO, Tanglewood Limestone Member, 108-110 ft; USGS 1129-CO, Millersburg Member, $163 \mathrm{ft}$; USGS D1132-CO, Tanglewood Limestone Member, $183 \mathrm{ft}$.

Locality 3.-Sadieville A, roadcuts on I-75, northbound lane, south side of Big Eagle Creek, Sadieville 7.5 minute Quadrangle, Scott County (section 179 of Cressman, 1973). Coordinates: base of section about 181 $\mathrm{mm}$ east, $108 \mathrm{~mm}$ north. One sample, USGS 5183-CO, was collected from the Clays Ferry Formation, $4 \mathrm{ft}$ above the base of the lower tongue.

Locality 4.-Sadieville C, roadcuts just west of Sadieville on the road between Sadieville and Church in the Wildwood, Sadieville 7.5-minute Quadrangle, Scott County (section 192 of Cressman, 1973). Coordinates: base of section at $295 \mathrm{~mm}$ east, $63 \mathrm{~mm}$ north. Eighteen collections were made in both the Lexington Limestone and Clays Ferry Formation. All the footage notations refer to distance above base of section: USGS 7450-CO, Clays Ferry Formation, $5 \mathrm{ft}$; USGS 7452-CO, Clays Ferry Formation, $10 \mathrm{ft}$; USGS 7454-CO, Lexington Limestone, Millersburg Member, $20 \mathrm{ft}$; USGS 7455-CO, Lexington Limestone, Millerburg Member, $22 \mathrm{ft}$; USGS 7456-CO, Lexington Limestone, Millersburg Member, $30 \mathrm{ft}$; USGS 7457-CO, Lexington Limestone,
Millersburg Member, $32 \mathrm{ft}$; USGS 7458-CO, Clays Ferry Formation, $35 \mathrm{ft}$; USGS 7459-CO, Clays Ferry Formation, $50 \mathrm{ft}$; USGS 7460-CO, Clays Ferry Formation, 55 $\mathrm{ft}$; USGS 7461-CO, Clays Ferry Formation, $50-55 \mathrm{ft}$; USGS 7462-CO, Clays Ferry Formation, $57 \mathrm{ft}$; USGS 7467-CO, Lexington Limestone, Tanglewood Limestone Member, $77 \mathrm{ft}$; USGS 7468-CO, Clays Ferry Formation, $82 \mathrm{ft}$; USGS 7471-CO, Clays Ferry Formation, $97 \mathrm{ft}$; USGS 7472-CO, Clays Ferry Formation, 100 $\mathrm{ft}$; USGS 7475-CO, Clays Ferry Formation, $115 \mathrm{ft}$; USGS 7477-CO, Clays Ferry Formation, $142 \mathrm{ft}$; USGS 7478-CO, Clays Ferry Formation, 145-148 ft.

Locality 5.-Devils Hollow Road, roadcuts along Devils Hollow Road, 0.7 miles south of Buttimer Hill, Frankfort West 7.5-minute Quadrangle, Franklin County. Coordinates: $411 \mathrm{~mm}$ east, $318 \mathrm{~mm}$ north. One sample, USGS 5093-CO, was collected from float in the Lexington Limestone, Grier Limestone Member, Macedonia Bed.

Locality 6. - Frankfort East A, roadcuts on I-64, just east of the Kentucky River Bridge, Frankfort East 7.5-minute Quadrangle, Franklin County (section 86 of Cressman, 1973). Three samples were collected from the Lexington Limestone: USGS 5089-CO (coordinates: 97 $\mathrm{mm}$ east, $173 \mathrm{~mm}$ north), from the top of the Macedonia 
Average percent occurrence

\begin{tabular}{|l|l|l|l|l|l|l|}
\hline 1 & & & & \\
0 & & & & & \\
100
\end{tabular}

1. Warthinia

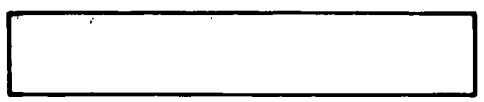

2. Jonesella

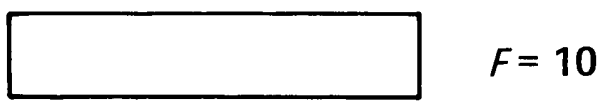

3. Ceratopsis

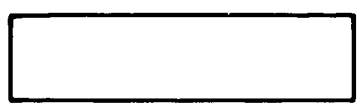

4. Ostracoda, indet.

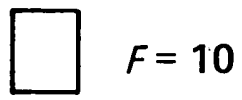

5. Phelobythocypris

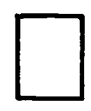

6. Leperditella?

$$
\begin{aligned}
& N=1 \\
& H(G)=1.441
\end{aligned}
$$

FIGURE 11. - Histogram of the single collection in outlier I (see fig. 2). $F$, fidelity; $H(G)$, compound generic diversity; $G$, simple generic diversity.

Bed of the Grier Limestone Member; USGS D1196-CO (coordinates: base of section at $88 \mathrm{~mm}$ east, $164 \mathrm{~mm}$ north), from $0.5 \mathrm{ft}$ below the top of the Logana Member; D1207-CO (coordinates: base of collected section at $112.5 \mathrm{~mm}$ east, $188 \mathrm{~mm}$ north), from the Devils Hollow Member.

Locality 7.-Tyrone C, outcrop on south side of railroad spur, 0.5 mile northeast of crossing of U.S. 62 and Kentucky River, Tyrone 7.5-minute Quadrangle, Woodford County (section 174 of Cressman, 1973). Coordinates: base of section $108 \mathrm{~mm}$ east, $197 \mathrm{~mm}$ north. Two collections were made, one, USGS 5083-CO, from the lowest foot of the Curdsville Limestone Member, and one, USGS 5086-CO, from the Logana Member of the Lexington Limestone, $18-20 \mathrm{ft}$ above the base of the Logana.

Locality 8. - Keene A, first outcrop southeast of crossing of Kentucky Route 33 and Clear Creek, Keene 7.5-minute Quadrangle, Woodford County. Coordinates: base of section at $21 \mathrm{~mm}$ east, $326 \mathrm{~mm}$ north. One sample, USGS 5022-CO, was collected from float in the lower $22 \mathrm{ft}$ of the Curdsville Limestone Member of the Lexington Limestone.

Locality 9. - Nicholasville I (Denny core). One sample, USGS 5899-CO, obtained from the Curdsville Limestone Member of the Lexington Limestone, 184.4 $\mathrm{ft}$ below the top of the core, contained a poorly preserved phosphatic ostracode fauna; Nicholasville 7.5-minute Quadrangle, Jessamine County (section 152 of Cressman, 1973). Coordinates: $241 \mathrm{~mm}$ east, $185 \mathrm{~mm}$ north.

Locality 10.-Hickman Creek, roadcuts on Kentucky Route 169, just west of the crossing of Hickman Creek, Nicholasville 7.5-minute Quadrangle, Jessamine County. Coordinates: $398 \mathrm{~mm}$ east, $81 \mathrm{~mm}$ north. One poor collection, USGS 5101-CO, was obtained from the lower part of the Curdsville Limestone Member, Lexington Limestone.

Locality 11. - Daniel Boone Y.M.C.A. Camp. Section is an abandoned railroad bed near the top of the bluff on the north side of the Kentucky River, west of the ferry crossing at Tate Creek Road, Valley View 7.5-minute Quadrangle, Jessamine County. Coordinates: $151 \mathrm{~mm}$ 
east, $432 \mathrm{~mm}$ north. One collection, USGS 5096-CO, was obtained from the Grier Limestone Member of the Lexington Limestone.

Locality 12. - Valley View B (Hunters Ferry Road), roadcuts along Hunters Ferry Road, 0.85 mile northeast of Trinity Church, Valley View 7.5-minute Quadrangle, Jessamine County (section 34, Cressman, 1973). Coordinates: $54 \mathrm{~mm}$ east, $262 \mathrm{~mm}$ north. One collection, USGS 4191-CO, was obtained from the Grier Limestone Member of the Lexington Limestone, $68.7 \mathrm{ft}$ below the top of the formation.

Locality 13. - Valley View C (Antioch Church Road), roadcuts between Trinity Church and Antioch Church, 1 mile southwest of the northern termination of Kentucky Route 595 at the Kentucky River, Valley View 7.5-minute Quadrangle, Jessamine County (section 180 of Cressman, 1973). Coordinates: base of section at 19 $\mathrm{mm}$ east, $176 \mathrm{~mm}$ north. Three ostracode-bearing samples were recovered from the Grier Limestone Member of the Lexington Limestone: USGS 4876-CO, $31 \mathrm{ft}$ above the base of the section; USGS 4879-CO, 38-41 ft above base; USGS 4880-CO, $44 \mathrm{ft}$. above base. Another collection, D1629-CO, was collected at this locality from an unknown interval.

Locality 14. - Clays Ferry type section, supplement; outcrops along old road to lower Clays Ferry Bridge (see Weir and Greene, 1965, p. B3, for a detailed map of the section), Ford 7.5-minute Quadrangle, Madison County. Coordinates: base of section at $132 \mathrm{~mm}$ east, $31 \mathrm{~mm}$ north. Three ostracode-bearing collections were obtained from the Clays Ferry Formation at this locality: USGS D1169-CO, $8 \mathrm{ft}$ above the contact with the underlying Tanglewood Limestone Member of the Lexington Limestone; USGS D1170-CO, $10 \mathrm{ft}$ above the contact; USGS D1171-CO, $15 \mathrm{ft}$ above the contact.

Locality 15. - Ford-Boonesboro Road, outcrops along the Ford-Boonesboro Road, on the east side of the Kentucky River, 0.55 mile south of the Memorial Bridge crossing, opposite Boonesboro Beach, Ford 7.5-minute Quadrangle, Clark County. Coordinates: $414 \mathrm{~mm}$ east, $112 \mathrm{~mm}$ north. One ostracode-bearing sample, USGS 6945-CO, was collected from the Clays Ferry Formation at this locality; the collection was obtained $17 \mathrm{ft}$ above the top of the Tanglewood Limestone Member of the Lexington Limestone.

Locality 16. - Dry Fork Road (Winchester A); roadcuts along Dry Fork Road, 0.7 mile southeast of the intersection of Dry Fork Road and Kentucky Route 974 (Muddy Creek Road), Winchester 7.5-minute Quadrangle, Clark County (section 1004 of Cressman, 1973). Coordinates: base of section at $394 \mathrm{~mm}$ east, $268 \mathrm{~mm}$ north. Twenty collections were made in the Lexington Limestone and Clays Ferry Formation. The footage notations are indicative of the distance above the $823-\mathrm{ft}$ benchmark that each sample was collected: USGS 7039-CO, Lexington
Limestone, Millersburg Member, $3 \mathrm{ft}$; USGS 7040-CO, Lexington Limestone, Millersburg Member, $4 \mathrm{ft}$; USGS 7041-CO, Lexington Limestone, Millersburg Member, 5 ft; USGS 7079-CO, Lexington Limestone, Millersburg Member, 6-9 ft; USGS 7043-CO, Clays Ferry Formation, tongue within Millersburg Member of Lexington Limestone, $10 \mathrm{ft}$; USGS 7045-CO, Clays Ferry Formation, tongue within Millersburg, $15 \mathrm{ft}$; USGS 7046-CO, Clays Ferry Formation, tongue within Millersburg, 18 $\mathrm{ft}$; USGS 7047-CO, Lexington Limestone, Millersburg Member, $21 \mathrm{ft}$; USGS 7050-CO, Lexington Limestone, Millersburg Member, $27 \mathrm{ft}$; USGS 7053-CO, Lexington Limestone, Millersburg Member, $31 \mathrm{ft}$; USGS 7054-CO, Lexington Limestone, Millersburg Member, $32 \mathrm{ft}$; USGS 7055-CO, Lexington Limestone, Millersburg Member, $35 \mathrm{ft}$; USGS 7056-CO, Lexington Limestone, Millersburg Member, $36 \mathrm{ft}$; USGS 7059-CO, Lexington Limestone, Millersburg Member, $42 \mathrm{ft}$; USGS 7060-CO, Lexington Limestone, Millersburg Member, $45 \mathrm{ft}$; USGS 7061-CO, Lexington Limestone, Millersburg Member, $46 \mathrm{ft}$; USGS 7062-CO, Lexington Limestone, tongue of the Tanglewood Limestone Member, $50 \mathrm{ft}$; USGS 7068-CO, Lexington Limestone, Millersburg Member, $63 \mathrm{ft}$; USGS 7071-CO, Lexington Limestone, tongue of the Tanglewood Limestone Member, 67. ft; USGS 7072-CO, Lexington Limestone, Millersburg Member, $71 \mathrm{ft}$.

Locality 17. - Kentucky Route 89, roadcuts along Kentucky Route 89, southeast of Winchester, Winchester 7.5-minute Quadrangle, Clark County. Coordinates: 413 $\mathrm{mm}$ east, $497 \mathrm{~mm}$ north. One ostracode-bearing collection (collection C of Black and Cuppels, 1973, p. C9), USGS 7312-CO, was obtained from the highest part of the Strodes Creek Member of the Lexington Limestone.

Locality 18. - Winchester reference section B, Maple Street (see Black and Cuppels, 1973, p. C13). Coordinates: base of section at $268 \mathrm{~mm}$ east, $567 \mathrm{~mm}$ north. Roadcuts on Maple Street (U.S. Route 227) on the northern outskirts of Winchester, Winchester 7.5-minute Quadrangle, Clark County. One ostracode-rich sample, USGS 7318-CO, was obtained from the Strodes Creek Member of the Lexington Limestone, $10 \mathrm{ft}$ above the base of the section.

Locality 19. - U.S. Route 227, roadcuts on U.S. Route 227 just north of I-64; Austerlitz 7.5-minute Quadrangle, Clark County (collection O of Black and Cuppels, 1973, p. C10). Coordinates: $266 \mathrm{~mm}$ east, 93 $\mathrm{mm}$ north. USGS 7325-CO was collected from the Strodes Creek Member of the Lexington Limestone.

Locality 20.-Bryantsville B (MacQuown BB), 0.15 miles east of Balls Branch, Bryantsville 7.5-minute Quadrangle, Boyle County. Coordinates: $74 \mathrm{~mm}$ east, 35 mm north. One ostracode collection, USGS 6137-CO, was recovered from the Salvisa Bed of the Perryville 
Limestone Member, Lexington Limestone, $8 \mathrm{ft}$ above the Perryville-Tanglewood contact.

Locality 21. - Perryville North, quarry off U.S. Route 68, 1 mile north of the junction with U.S. Route 150, Perryville 7.5-minute Quadrangle, Boyle County (section 30A of Cressman, 1973). Coordinates: $217 \mathrm{~mm}$ east, $176 \mathrm{~mm}$ north. One ostracode collection, USGS $6915-\mathrm{CO}$, was obtained from the basal $2 \mathrm{ft}$ of the Salvisa Bed of the Perryville Limestone Member, Lexington Limestone, $42 \mathrm{ft}$ above the contact with the underlying Tanglewood Limestone Member, of the Lexington.

Locality 22. - Perryville South, quarry 0.4 miles south of Perryville, on east side of the Chaplin River, Perryville Quadrangle, Boyle County (section 30B of Cressman, 1973). Coordinates: $191 \mathrm{~mm}$ east, $92 \mathrm{~mm}$ north. One collection, USGS 5015-CO, was obtained from the Salvisa Bed of the Perryville Limestone Member, Lexington Limestone, $5 \mathrm{ft}$ above the base of the member.

\section{SYSTEMATIC PALEONTOLOGY}

Suprageneric classification of the Class Ostracoda is based largely on the "Treatise on Invertebrate Paleontology - Part Q, Arthropoda 3" edited by Moore (1961), with some modifications from Henningsmoen (1965). The terms used for morphologic features are also based on the "Treatise" and Henningsmoen. The synonymies presented in this study include mostly those references that add information, whether written or visual, to our understanding of the species. This fact is important, as much of the previous literature consists only of restatements of the original descriptions and (or) figures. For synonymies that include all earlier works, see Bassler and Kellett (1934).

Wherever sufficient height/length data are available to describe growth mathmetically, it is defined by using the allometric equation $y=a x^{b}$. In all instances correlation coefficients $(r$, calculated by using a least-squares fit) were higher for the allometric equation than for corresponding linear-regression models, $y=c+d x$. Although the exponential values for the calculated allometric equations always approached unity, they never were equal to unity, indicating a degree of curvilinear growth.

Occurrence data for forms reported from outside the central Kentucky and Cincinnati areas are based almost entirely on literature reports. A cursory examination of some of the specimens reportedly conspecific with the Kentucky material, both old and new, has shown them to differ on at least a specific level. Therefore, many of the occurences reported in the systematic section for areas other than Kentucky are of doubtful validity. Occurence data for the new material are given for forma- tion, member, and USGS collection number. The number in parenthesis next to each USGS collection number shows the number of specimens of that particular species in the sample.

Abbreviations used for institutions from which collection or specimen numbers are cited are as follows: Geological Survey of Canada, GSC; Field Museum of Natural History, Chicago, UC; Museum of Paleontology, University of California, Berkeley, UCMP; U.S. Geological Survey, USGS; U.S. National Museum of Natural History, USNM; Yale Peabody Museum, YPM. All the new type specimens are deposited in the USNM unless otherwise indicated. The nontype material is in the collection of the USGS.

Class OSTRACODA Latreille, 1804

Order PALAEOCOPIDA Henningsmoen, 1953

Suborder BEYRICHICOPINA Scott, 1961

Superfamily DREPANELLACEA Ulrich and Bassler, 1923

Family BOLLIIDAE Bouček, 1936

Genus QUASIBOLLIA n. gen.

Type species. -Beyrichia persulcata Ulrich, 1879.

Species included.-Bollia ridicula Keenan, 1951.

Quasibollia copelandi, n.sp.

Diagnosis. - Small, subquadrate bolliids having L1 and L4 merged with velar ridge and L3 separated into lobe and dorsal knob by deep horizontal furrow. L2 may or may not be constricted, and bolliid U-shaped connecting lobe may overhang velar ridge ventromedially. Small node may be present behind velar ridge at anterodorsal corner.

Discussion.-The new genus Quasibollia may be distinguished from Bollia s.s. by the distinct horizontal furrow dividing L3 together with its subquadrate outline. The type species of Bollia, B. bicollina Jones and Holl, 1886 (see Guber, 1968; Melville, 1970) lacks the furrow on L3 and is more semicircular in lateral outline. Although some Devonian species of Bollia, such $B$. americana zygocornis Swartz, 1936, B. diceratina Swartz and Swain, 1941, B. disjuncta Kesling and Kilgore, 1952, B. hindei Jones, 1890, and B. obesa Ulrich, 1891, also have a constriction or horizontal sulcus on L3, these species characteristically have a semicircular lateral outline.

Ulrich (1894, see 1897, p. 668-669) listed all the species that he then considered to belong in the genus Bollia and grouped them in three sections; he placed Bollia bicollina in his first section and Bollia unguloidea Ulrich, 1894, $B$. regularis (Emmons, 1855), and $B$. persulcata as Ordovician representatives of his third section. Kesling and Hussey (1953, p. 85-86) placed $B$. regularis in their new genus Quadrijugator, which 
differs from Quasibollia in having regular and undivided lobes. The type specimen of $B$. unguloidea is apparently lost; Bassler and Kellett (1934, p. 220) did not list a USNM number for it, and Berdan has been unable to find it in the collections of the USNM. However, Ulrich (1894, see 1897, pl. 46, figs. 23-25) illustrated his species with a divided L3; this species may also belong in Quasibollia.

The generic name is based on the Latin word "quasi," meaning "simulating," combined with Bollia; the gender is feminine.

Geologic range.-Middle and Upper Ordovician (Kirkfieldian (?) to Richmondian Stages) of the central interior of North America.

\section{Quasibollia persulcata (Ulrich, 1879)}

Plate 1, figures 2, 4-10

1879. Beyrichia persulcata Ulrich, p. 12, pl. 7, fig. 6 . 1890. Beyrichia buchiana? Jones, p. 16, pl. 3, fig. 25 (not Beyrichia buchiana Jones, 1855).

1890. Bollia persulcata (Ulrich). Ulrich, p. 116, text-fig. 3a-d.

1908. Bollia persulcata (Ulrich). Ulrich and Bassler, p. 288.

1951. Bollia persulcata (Ulrich). Keenan, p. 564, pl. 78, figs. 2, 3.

1965. not Bollia persulcata (Ulrich). Copeland, p. 8, pl. 11, figs. 9, 11.

Diagnosis. -L2 slightly constricted, about same width as anterior part of velar ridge. No anterodorsal node. Velar ridge reduced ventrally.

Description. - Lateral outline nearly amplete, valves equal in size and subrectangular in lateral view. Greatest height from hingeline to ventral margin is just anterior to L2, greatest length at midheight, and greatest width at the middle of L3. Hingeline straight, approximately 90 percent of greatest length. Anterior margin strongly convex; ventral margin may be slightly concave or straight and is subparallel to dorsal margin; posterior margin is weakly convex and subperpendicular. Anterior cardinal angle obtuse, posterior cardinal angle acute.

Prominent velar ridge parallels marginal rim around anterior and posterior parts of free margins, and curves admarginally on ventral part of valves so that it almost merges with marginal rim. In lateral view, wide anterior and posterior segments of velar ridge conceal marginal rim and are separated from it by narrow canaliculus, which is nearly lacking midventrally. $\mathrm{L} 2$ is variable and may be straight, medianly inflated, or medianly constricted. L3 slightly longer than L2 and has dorsal third separated into hemispherical to suboblong knob by deep furrow. Dorsal parts of both lobes project above hingeline; ventrally they are united to form U-shaped structure, which is constricted ventrally and may obscure velar ridge and marginal rim in lateral view. S2 is deep and long, extending almost to ventral margin.
Internally, velar ridge appears as two deep grooves, one anterior and other posterior, with no ventral connection. L2 and L3 also appear as deep grooves which are not connected ventrally and which are separated by long high ridge of S2. Dorsal knob of L3 reflected internally as deep wide pit. Small pit, with no apparent external reflection, is just posterior of anterodorsal corner and is clearly defined on many phosphatic molds as small node.

Surface of valves ranges from smooth to finely granulose. Hingement appears to be simple.

Measurements. -The lectotype (USNM 41524a) is $0.577 \mathrm{~mm}$ long and $0.325 \mathrm{~mm}$ high. Another paralectotype right valve (USNM $41524 \mathrm{e}$ ) is also $0.577 \mathrm{~mm}$ long and $0.325 \mathrm{~mm}$ high. The only paralecototype left valve (USNM 41524d) is $0.550 \mathrm{~mm}$ long and $0.325 \mathrm{~mm}$ high. Table 3 gives measurements of two figured and 15 unfigured hypotypes and table 4 provides a statistical summary of the measurements.

Ontogeny. - Most of the 69 specimens from the Lexington Limestone and Clays Ferry Formation are too poorly preserved to measure accurately; however, a scatter diagram (fig. 12) showing the length plotted against the height for 17 specimens from two stratigraphically adjacent collections suggests that three, and possibly four, growth stages may be recognized. The smallest specimen (USNM 239961; pl.1, fig. 9 ), which represents either the adult-2 (A-2) or adult-3 growth stages, differs from the adults in having L2 divided into two parts by a horizontal furrow, so that it resembles L3. In addition, the ventral part of the $\mathrm{U}$-shaped structure is narrow and does not extend to the ventral border as it does in the adults. The division of both lobes gives the valve the appearance of having four large nodes, of which the most conspicuous is the posterodorsal node also present in the adults. Although this smallest specimen appears to be quite different from the adults, the intervening growth stages seem to have a morphology intermediate between it and the adults.

Growth of this species, as defined by the allometric equation, height $=0.574$, length $=1.081$, approaches linearity which is readily evident by noting the closeness of the exponential value to unity. A least-square fit of the calculated equation to the points indicates a high degree of correlation, $r=0.996$.

Discussion. - The type lot of Quasibollia persulcata consists of six specimens glued to a strip of cardboard on which is written "Bollia persulcata Ulrich, Eden gr.-Lower division, Covington, Ky., Holotype 41,524." As Ulrich's original drawing does not show which specimen he considered the holotype, the specimens have been lettered a-f, and the well-preserved right 
valve in the upper left corner of the strip, USNM 41524a, is here designated the lectotype (pl. 1, fig. 2); remaining specimens, USNM $41524 \mathrm{~b}-\mathrm{f}$, become paralectotypes.

Quasibollia persulcata most closely resembles $Q$. ridicula (Keenan, 1951) from the Upper Ordovician Maquoketa Shale of Missouri (pl. 1, fig. 3), from which it differs, as noted by Keenan (1951, p. 569), in lacking a small anterodorsal node. Furthermore, the velar ridge and the lobes of $Q$. ridicula are higher and narrower than are the same structures of $Q$. persulcata. Like $Q$. persulcata, juvenile specimens of $Q$. ridicula also have both lobes divided (Keenan, 1951, pl. 79, fig. 37).

Copeland $(1965$, p. 8, pl. 11, figs. 9, 11) discussed and illustrated two specimens, which he assigned to Bollia persulcata (Ulrich), from Middle Ordovician beds in the Lake Timiskaming area, Ontario. These specimens resemble juvenile instars of $Q$. persulcata and $Q$. ridicula in having both lobes subdivided by horizontal furrows, but their size is comparable with that of the adult-1 instar of $Q$. persulcata, and they have an external anterodorsal node. They are here considered to belong to a new species of Quasibollia.

The shell of $Q$. persulcata is relatively thick in relation to the small size of the adult ostracode. As noted in the description of the species, the small anterodorsal node characteristic of $Q$. ridicula and the Ontario specimens is not visible externally on $Q$. persulcata but is represented by a pit on the inside of the shell, which appears as a node on phosphatic steinkerns (pl. 1, figs. 6 , 10). In addition, $L 1$ seems more constricted internally.

Although Keenan (1951, p. 569, pl. 78, figs. 2, 3) did not redescribe $Q$. persulcata, he illustrated one adult and one juvenile specimen from the base of the Edenian at Cincinnati; these were the first published photographs of the species.

Types.-Lectotype, USNM 41524a; paralectotypes, USNM 41524b-f; figured hypotypes, USNM 239961,
239963, 239965, 239966, 271012, 271013; unfigured hypotypes, USNM 239962 (7 specimens), 239964 (8 specimens).

Occurrence.-The lectotype and paralectotypes of Quasibollia persulcata came from the "Eden gr., Lower division, Covington, Ky.," according to the label with USNM 41524, or from what is now the Kope Formation. The hypotypes discussed in this paper occur in both the Lexington Limestone (Grier, Millersburg, Strodes Creek and Tanglewood) and the Clays Ferry Formation. Thus, on the basis of the material described here, the species occurs in rocks of Shermanian (late Middle Ordovician) and Edenian (early Late Ordovician) age. A total of 69 specimens was obtained from the following six USGS localities and 19 collections: Ford-Boonesboro Road, 6945-CO (3); Dryfork Road, 7043-CO (5), 7045-CO (1), 7046-CO (1), 7047-CO (2), 7079-CO (4); Kentucky Route 89, 7312-CO (1); U.S. Route 227, 7325-CO (2); Sadieville C, 7454-CO (14), 7455-CO (11), 7456-CO (3), 7461-CO (1), 7462-CO (4), 7467-CO (3), 7468-CO (1), 7471-CO (6), 7478-CO (1); Switzer A, D1115-CO (5), D1117-CO (1).

This species has also been reported from the Maysvillian and Richmondian (Late Ordovician) of the Cincinnati area (Bassler, 1915; Bassler and Kellett, 1934; Keenan, 1951).

\section{Quasibollia copelandi n. sp. Plate 1, figure 1}

1965. Bollia persulcata (Ulrich). Copeland, p. 8, pl. 11, figs. 9, 11.

Diagnosis. -Quasibollia having both lobes divided by horizontal furrows in adult instar. Small anterodorsal node present.

Description. - Lateral outline amplete; dorsal margin straight, anterior margin smoothly curved, ventral margin slightly concave midventrally, and posterior

TABLE 3.-Measurements (in $\mathrm{mm}$ ) of 17 specimens of Quasibollia persulcata from the Millersburg Member of the Lexington Limestone

\begin{tabular}{|c|c|c|c|c|c|c|c|}
\hline & Type & $\begin{array}{l}\text { USNM } \\
\text { No. }\end{array}$ & $\begin{array}{c}\text { USGS } \\
\text { colln. No. }\end{array}$ & Valve & Length & Height & Hingeline \\
\hline 1 & Figured hypotype & 239961 & $7454-\mathrm{CO}$ & right __-_._-_- & 0.340 & 0.176 & 0.277 \\
\hline 2 & Unfigured hypotype & 239962 & $7454-\mathrm{CO}$ & - & .434 & .239 & .365 \\
\hline 3 & do & 239962 & $7454-\mathrm{CO}$ & -_-_do _-_._. & .454 & .227 & .384 \\
\hline 4 & - do & 239962 & $7454-\mathrm{CO}$ & - - - do & .507 & .268 & .447 \\
\hline 5 & do & 239962 & $7454-\mathrm{CO}$ & left & .403 & .208 & .340 \\
\hline 6 & - do & 239962 & $7454-\mathrm{CO}$ & right _ & .466 & .268 & .390 \\
\hline 7 & - do b-o- & 239962 & $7454-\mathrm{CO}$ & - - - do & .416 & .224 & .321 \\
\hline 8 & - & 239962 & $7454-\mathrm{CO}$ & left & .473 & .271 & .410 \\
\hline 9 & Figured hypotype & 239963 & $7455-\mathrm{CO}$ & right & .548 & .299 & .485 \\
\hline 10 & Unfigured hypotype _- & 239964 & $7455-\mathrm{CO}$ & left__ & .498 & .274 & .403 \\
\hline 11 & 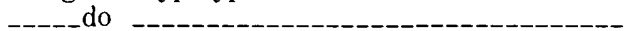 & 239964 & $7455-\mathrm{CO}$ & _-_-_do _-_.._-_ & .537 & .293 & .435 \\
\hline 12 & - & 239964 & $7455-\mathrm{CO}$ & _-_-_do _-_._-_ & .517 & .306 & .441 \\
\hline 13 & - do & 239964 & $7455-\mathrm{CO}$ & - - - do do _-_-_- & .567 & .302 & .435 \\
\hline 14 & do & 239964 & $7455-\mathrm{CO}$ & --_-_do & .529 & .293 & .441 \\
\hline 15 & - do - - d & 239964 & $7455-\mathrm{CO}$ & right _._-_-_-_- & .592 & .323 & .504 \\
\hline 16 & - do & 239964 & $7455-\mathrm{CO}$ & - & .548 & .290 & .498 \\
\hline 17 & do & 239964 & $7455-\mathrm{CO}$ & left_- & .523 & .272 & .441 \\
\hline
\end{tabular}


TABLE 4.-Statistical summary of measurements (in $\mathrm{mm}$ ) for Quasibollia persulcata from USGS colln. No. 7454-CO and 7455-CO

\begin{tabular}{|c|c|c|c|c|c|c|c|}
\hline \multirow[b]{2}{*}{ Instar } & \multirow{2}{*}{$\begin{array}{c}\text { No. of } \\
\text { specimens }\end{array}$} & \multicolumn{3}{|c|}{ Length } & \multicolumn{3}{|c|}{ Height } \\
\hline & & Mean & Minimum & Maximum & Mean & Minimum & Maximum \\
\hline Adult & 7 & 0.548 & 0.517 & 0.592 & 0.301 & 0.290 & 0.323 \\
\hline $\mathrm{A}-1$ & 5 & .493 & .466 & .523 & .270 & .268 & .274 \\
\hline $\mathrm{A}-2$ & 4 & .427 & .403 & .454 & .224 & .208 & .239 \\
\hline A-3 & 1 & .176 & ---- & ---- & .340 & ---- & ---- \\
\hline
\end{tabular}

margin gently curved. Greatest height through L2 and greatest length slightly above midheight. Anterior cardinal angle obtuse and posterior cardinal angle approximately $90^{\circ}$. Velar ridge high and parallels free margin anteriorly and posteriorly, obscuring it in lateral view; ventrally very low and almost merges with free margin. S1 and S2 of about equal width, S3 wider than either. L2 divided at about two-thirds of its height by posteriorly slanting furrow; L3 also divided by posteriorly slanting furrow, its dorsal third forms bulbous knob that protrudes above hingeline. Both lobes connected ventrally by low obscure U-shaped yoke. Small node in anterodorsal corner. Surface of both lobes and sulci appears to be smooth. Hingement and interior were not observed.
Measurements. - The holotype is $0.525 \mathrm{~mm}$ long anc $0.300 \mathrm{~mm}$ high. The paratype also is $0.525 \mathrm{~mm}$ long anc $0.300 \mathrm{~mm}$ high.

Discussion. - As noted under the discussion of $Q$. per. sulcata, $Q$. copelandi differs from other species of the genus in having L3 divided into two nodes so that the valves appear quadrinodose in the adult and subadult instars. It also differs in having the ventral connection between L2 and L3 less well developed than either of the other species. In addition, it may be distinguished from Q. persulcata by the presence of the well-defined small node in the anterodorsal corner. Although juvenile specimens of $Q$. persulcdta and $Q$. ridicula have the same characters as $Q$. copelandi, we consider the presence of these characters in the subadult and adult instars together with its somewhat greater age (Wildernessian, according to Copeland, 1965, p. 1-3) as evidence that $Q$. copelandi is a valid species. The succession of $Q$. copelandi with divided L2 in the Wildernessian, Q. persulcata with constricted L2 in the Barneveldian and Edenian, and Q. ridicula (pl. 1, fig. 3) with undivided L2 in the Richmondian suggests the possibility

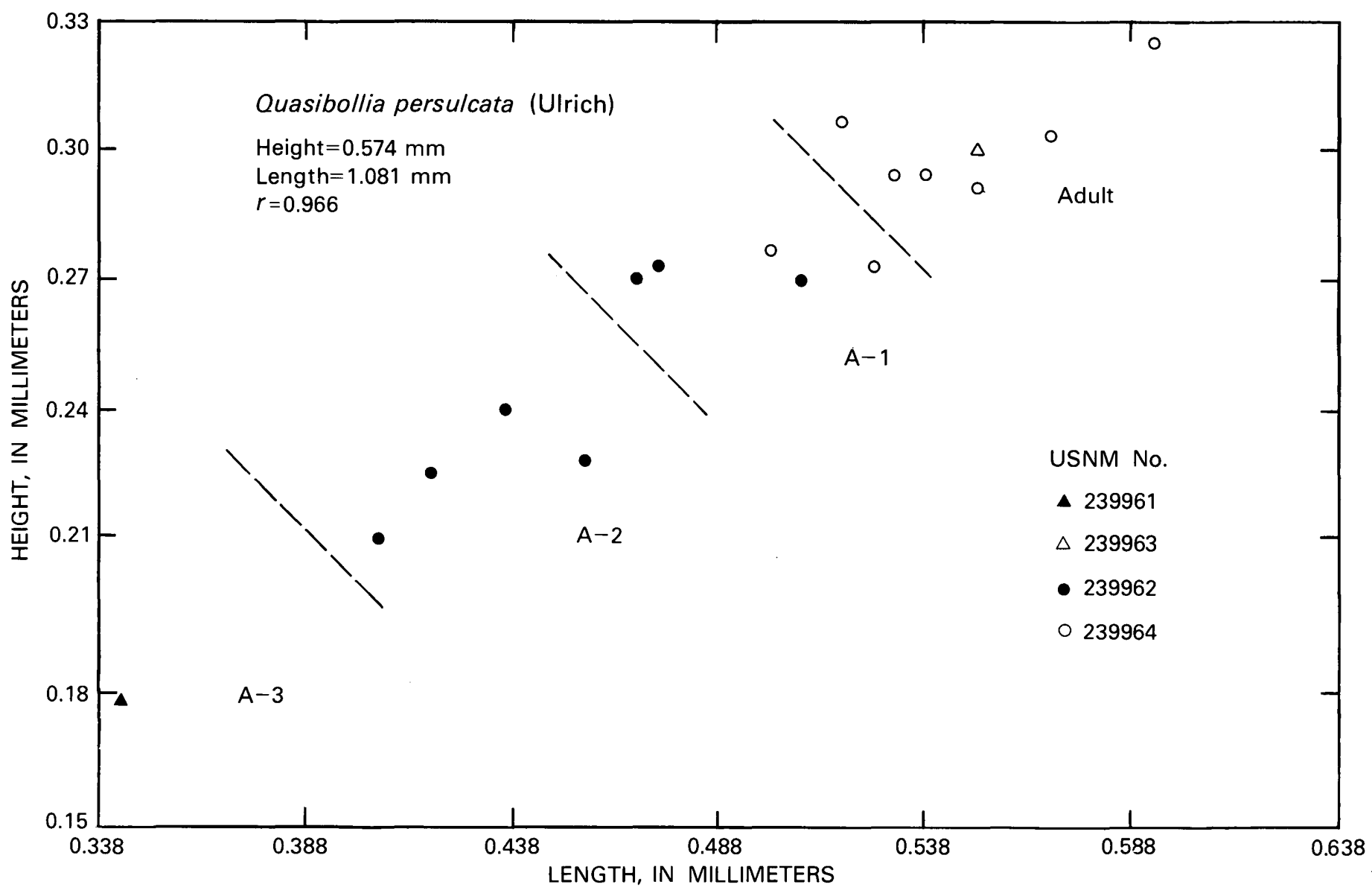

FIGURE 12.-Size-dispersion diagram for 17 specimens of Quasibollia persulcata from the Millersburg Member of the Lexington Limestone at Sadieville. See table 3 for the USGS collection numbers. 
of a phylogenetic trend toward uniting the nodes of L2 in the genus Quasibollia, but as yet there is not enough evidence to confirm this.

The species is named in honor of Dr. Murray J. Copeland of the Geological Survey of Canada, who loaned us his specimens and suggested that we base a new species on them.

Types. - Holotype, GSC 10784a; paratype, GSC 10784.

Occurrence.-Bucke Formation, gray shale, 1963 borehole near southwest shore of Wabi Point, Harris Township, Ontario; depth 660-663 ft (Copeland, 1965, p. 8).

\section{Quasibollia? sp. \\ Plate 1, figure 11}

Discussion.-Four incomplete phosphatic molds are questionably assigned to Quasibollia because of general similarities in lobation. The specimens are amplete in lateral outline and have four lobes, one elongated perpendicular to the dorsal margin in the anterodorsal third of the valve, one elongated parallel to the anteroventral margin, one elongated parallel to the dorsal margin in the posterodorsal quadrant, and one curved posteroventral lobe with a carinate crest. A velar ridge is apparently present around the free margin. These specimens bear some resemblance to the type species of Eohollina Harris, 1957, E. irregularis (Spivey, 1939), but this species lacks a separate anteroventral lobe (Spivey, 1939, pl. 21, fig. 1). The two anterior lobes separated by a posteroventrally slanted sulcus is more suggestive of Quasibollia copelandi $\mathrm{n}$. $\mathrm{sp}$. but as internal molds of Quasibollia do not reflect accurately the appearance of the exterior of the valves, these specimens cannot be assigned unequivocally to a genus until more and better material is found. Two specimens were measured; the figured specimen is 0.512 $\mathrm{mm}$ long and $0.245 \mathrm{~mm}$ high, and a small specimen is $0.315 \mathrm{~mm}$ long and $0.183 \mathrm{~mm}$ high.

Types-Figured specimen, USNM 240016; unfigured measured specimen, USNM 240017.

Occurrence.-The specimens are from the Lexington Limestone (Grier and Tanglewood) and the Clays Ferry Formation. They are at two USGS localities and in three collections: Ford-Boonesboro Road, 6945-CO (1); Switzer A, D1115-CO (2), D1132-CO (1).

\section{Genus WARTHINIA Spivey, 1939}

Type species.-Primitia nodosa Ulrich, 1890, by original designation (Spivey, 1939, p. 167).

Species included.-Kiesowia verrucosa Kay, 1940, of Keenan, 1951.

Kiesowia binoda Keenan, 1951.

Kiesowia insolens Keenan, 1951.

Ulrichia saccula Burr and Swain, 1965.
Revised diagnosis.-Palaeocopid ostracodes having two, three, or four nodes, of which two are along hingeline. Posterior dorsal node larger than anterior dorsal node and may be spinose. Additional nodes, if present, anterior and anteroventral in position. Low velar ridge parallels free margin. Valve surface, including the nodes, finely reticulated.

Discussion. - The above rediagnosis differs from the original diagnosis of Spivey $(1939$, p. 167) by including species having only two nodes, such as Warthinia binoda (Keenan, 1951). Scott and Wainwright (in Moore, 1961) placed Warthinia questionably into synonymy with the Devonian genus Ulrichia Jones, 1890, which also is binodose. However, in Ulrichia, the two nodes are nearly equal in size, whereas in Warthinia the posterior node is distinctly larger than the others. In addition, the nodes of Warthinia tend to be reticulate, unlike those of Ulrichia, and the velar ridge is less well developed in Warthinia. For these reasons, we are reinstating the generic name Warthinia, as suggested by Guber (1963), to include bi- to quadrinodose finely reticulate bolliids having large posterior nodes.

The anterior-posterior orientation used in this paper is reversed from that previously used by other authors for Warthinia. It is based on the location of S2 and the inclination of the spines and pointed nodes (Triebel, 1941, p. 334-353). The quadrindose forms found in the present study are the first ones to be discussed since Ulrich (1890) described them in his original study.

Geologic range.-Middle and Upper Ordovician (Kirkfieldian (?) to Richmondian Stages) of east-central North America.

Warthinia nodosa (Ulrich, 1890)

Plate 1, figures 12-21; plate 2, figures 9-11

1890. Primitia nodosa Ulrich, p. 134, pl. 10, figs. 11 a-b, 12 a-b. 1891. Ulrichia nodosa (Ulrich). Ulrich, p. 203

1939. Warthinia nodosa (Ulrich). Spivey, p. 167, pl. 21, figs. 3-6. 1941. Ulrichia nodosa nodosa (Ulrich). Schmidt, p. 57.

1941. Ulrichia nodosa paupera (Ulrich). Schmidt, p. 57, pl. 4, figs, 30-31.

1951. Kiesowia nodosa (Ulrich). Keenan, p. 569, pl. 78, fig. 6 .

1965. ?Ulrichia nodosa (Ulrich). Burr and Swain, p. 14, pl. 4, figs. 2a-b, 3.

1970. Ulrichia nodosa (Ulrich). Copeland, p. 18, pl. 4, figs. 3, 4.

Diagnosis. - Finely reticulate Warthinia having wellformed ventral lobe connecting three and sometimes four nodes; nodes extremely variable and may be spinose, conical, or rounded.

Description.-Lateral outline amplete, semicircular valves, subequal in size. Left valve slightly larger than right valve (see fig. 13). Greatest height usually at midlength and rarely anterior or posterior to midlength. Greatest length dorsal to midheight and greatest thickness ventral to midheight. Dorsal margin straight 
to slightly convex, approximately 80 percent of greatest length. Ventral margin convex and grades laterally into convex anterior and posterior margins. Posterior margin more bluntly convex than anterior. Cardinal angles obtuse and subequal.

Well-developed velar ridge parallels marginal rim around entire free margin. Velar ridge and marginal rim coalesce at anterodorsal and posterodorsal corners. Wide shallow canaliculus with weakly developed longitudinal striae between velar ridge and marginal rim; canaliculus well developed around entire contact margin. Three, and sometimes four nodes on lateral surface of valves. Largest node is posterodorsal and varies from low and rounded to elongate and pointed. When pointed, nodes are posteriorly inclined. Anterodorsal node smaller than the posterodorsal. Anteroventral node slightly larger than anterodorsal. Anterodorsal and anteroventral nodes not as variable in shape as posterodorsal node. Fourth node, when present, is along the ventral border, almost directly underneath anterodorsal node. All nodes ventrally connected by low swelling of lateral valve surface. S2 moderately deep, short, and located between anterodorsal and posterodorsal nodes. Nodes, connecting lobe, and velar ridge internally reflected as corresponding depressions. $\mathrm{S} 2$ reflected as a prominence. Exterior surface of valves finely reticulate. Reticulation well developed on nodes but absent from velar ridge. Dorsum slightly epicline. Right valve overreaches left valve at cardinal corners. No hinge structure observed.

Measurements. - See table 5 for the measurements of 48 specimens of $W$. nodosa from Sadieville. Table 6 is a statistical summary of the measurements.

TABLE 5. - Measurements (in $\mathrm{mm}$ ) of 48 specimens of Warthinia nodosa from USGS colln. No. 7468-CO, from the Clays Ferry Formation [Specimens 1, USNM 239967; Specimen 2, USNM 239968; Specimens 4-48, USNM 239974]

\begin{tabular}{|c|c|c|c|c|c|}
\hline & $\begin{array}{l}\text { USNM } \\
\text { No. }\end{array}$ & Length & \multicolumn{3}{|c|}{$\begin{array}{c}\text { Posterior } \\
\text { node }\end{array}$} \\
\hline \multicolumn{6}{|c|}{ Figured hypotypes } \\
\hline $\begin{array}{l}1 \ldots-\ldots- \\
2\end{array}$ & $\begin{array}{l}239967 \\
239968\end{array}$ & Left --_------ & $\begin{array}{r}0.340 \\
.410 \\
\end{array}$ & $\begin{array}{r}0.202 \\
.246\end{array}$ & $\begin{array}{l}\text { Spinose. } \\
\text { Do. }\end{array}$ \\
\hline \multicolumn{6}{|c|}{ Unfigured hypotypes } \\
\hline $\begin{array}{l}3 \ldots- \\
4- \\
5 \\
6 \\
-\end{array}$ & $\begin{array}{l}239974 \\
239974 \\
239974 \\
239974\end{array}$ & 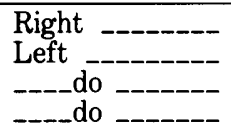 & $\begin{array}{l}.422 \\
.460 \\
.435 \\
.417\end{array}$ & $\begin{array}{l}.245 \\
.285 \\
.278 \\
.253\end{array}$ & $\begin{array}{l}\text { Pointed. } \\
\text { Do. } \\
\text { Do. } \\
\text { Spinose. }\end{array}$ \\
\hline $\begin{array}{r}7 \\
8 \\
9 \\
9 \\
10 \\
11 \\
12 \\
12- \\
\end{array}$ & $\begin{array}{l}239974 \\
239974 \\
239974 \\
239974 \\
239974 \\
239974\end{array}$ & 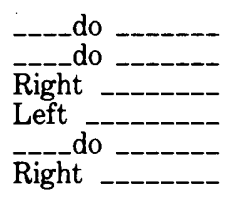 & $\begin{array}{l}.422 \\
.416 \\
.504 \\
.410 \\
.510 \\
.466\end{array}$ & $\begin{array}{l}.265 \\
.265 \\
.316 \\
.259 \\
.315 \\
.290\end{array}$ & $\begin{array}{l}\text { Pointed. } \\
\text { Do. } \\
\text { Rounded. } \\
\text { Pointed. } \\
\text { Rounded. } \\
\text { Pointed. }\end{array}$ \\
\hline $\begin{array}{l}13 \\
14 \\
15 \\
16 \\
17 \\
18\end{array}$ & $\begin{array}{l}239974 \\
239974 \\
239974 \\
239974 \\
239974 \\
239974\end{array}$ & 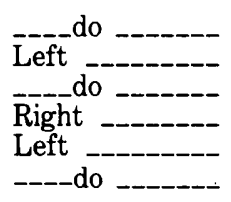 & $\begin{array}{l}.467 \\
.406 \\
.447 \\
.461 \\
.460 \\
.485\end{array}$ & $\begin{array}{l}.278 \\
.252 \\
.277 \\
.285 \\
.278 \\
.277\end{array}$ & $\begin{array}{l}\text { Rounded. } \\
\text { Pointed. } \\
\text { Rounded. } \\
\text { Do. } \\
\text { Do. } \\
\text { Spinose. }\end{array}$ \\
\hline
\end{tabular}

TABLE 5.-Measurements (in $\mathrm{mm}$ ) of 48 specimens of Warthinia nodosa from USGS colln. No. 7468-CO, from the Clays Ferry Formation-Continued

\begin{tabular}{|c|c|c|c|c|c|}
\hline & $\begin{array}{l}\text { USNM } \\
\text { No. }\end{array}$ & Length & Height & \multicolumn{2}{|c|}{$\begin{array}{c}\text { Posterior } \\
\text { node }\end{array}$} \\
\hline \multicolumn{6}{|c|}{ Unfigured hypotypes - Continued } \\
\hline $\begin{array}{l}19 \\
20 \\
21 \\
22 \\
23 \ldots--- \\
24 \\
24\end{array}$ & $\begin{array}{l}239974 \\
239974 \\
239974 \\
239974 \\
239974 \\
239974\end{array}$ & 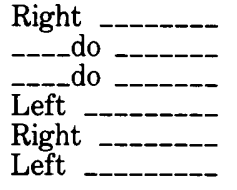 & $\begin{array}{l}.460 \\
.479 \\
.391 \\
.479 \\
.469 \\
.416\end{array}$ & $\begin{array}{l}.296 \\
.284 \\
.239 \\
.309 \\
.293 \\
.261\end{array}$ & $\begin{array}{l}\text { Do. } \\
\text { Pointed. } \\
\text { Spinose. } \\
\text { Pointed. } \\
\text { Do. } \\
\text { Spinose. }\end{array}$ \\
\hline $\begin{array}{l}25 \\
26 \\
27------- \\
28 \\
29 \\
30 \\
30- \\
-\end{array}$ & $\begin{array}{l}239974 \\
239974 \\
239974 \\
239974 \\
239974 \\
239974\end{array}$ & 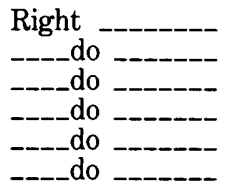 & $\begin{array}{l}.510 \\
.479 \\
.466 \\
.411 \\
.466 \\
.419\end{array}$ & $\begin{array}{l}.312 \\
.296 \\
.280 \\
.277 \\
.302 \\
.258\end{array}$ & $\begin{array}{l}\text { Rounded. } \\
\text { Spinose. } \\
\text { Rounded. } \\
\text { Pointed. } \\
\text { Do. } \\
\text { Spinose. }\end{array}$ \\
\hline $\begin{array}{l}31 \\
32 \\
33 \\
34 \\
35 \\
36 \\
36 \\
\ldots\end{array}$ & $\begin{array}{l}239974 \\
239974 \\
239974 \\
239974 \\
239974 \\
239974\end{array}$ & 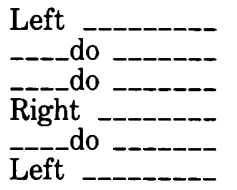 & $\begin{array}{l}.447 \\
.447 \\
.430 \\
.425 \\
.378 \\
.479\end{array}$ & $\begin{array}{l}.278 \\
.290 \\
.302 \\
.265 \\
.233 \\
.290\end{array}$ & $\begin{array}{l}\text { Rounded. } \\
\text { Pointed. } \\
\text { Rounded. } \\
\text { Spinose. } \\
\text { Pointed. } \\
\text { Do. }\end{array}$ \\
\hline $\begin{array}{l}37------ \\
38----- \\
39----- \\
40----- \\
41 \_---- \\
42----\end{array}$ & $\begin{array}{l}239974 \\
239974 \\
239974 \\
239974 \\
239974 \\
239974\end{array}$ & 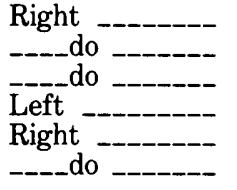 & $\begin{array}{l}.466 \\
.485 \\
.398 \\
.466 \\
.467 \\
.435\end{array}$ & $\begin{array}{l}.287 \\
.309 \\
.246 \\
.284 \\
.284 \\
.279\end{array}$ & $\begin{array}{l}\text { Do. } \\
\text { Do. } \\
\text { Spinose. } \\
\text { Pointed. } \\
\text { Do. } \\
\text { Do. }\end{array}$ \\
\hline $\begin{array}{l}43 \\
44 \\
45 \\
46 \\
47 \\
48\end{array}$ & $\begin{array}{l}239974 \\
239974 \\
239974 \\
239974 \\
239974 \\
239974\end{array}$ & 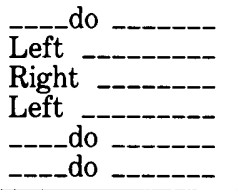 & $\begin{array}{l}.442 \\
.423 \\
.479 \\
.405 \\
.437 \\
.435\end{array}$ & $\begin{array}{l}.284 \\
.253 \\
.299 \\
.246 \\
.277 \\
.271\end{array}$ & $\begin{array}{l}\text { Broken. } \\
\text { Pointed. } \\
\text { Rounded. } \\
\text { Spinose. } \\
\text { Pointed. } \\
\text { Do. }\end{array}$ \\
\hline
\end{tabular}

Ontogeny. - The size-dispersion diagram (fig. 13) shows not only changes in absolute and relative size but also an ontogenetic change in valve morphology. The smallest instar yet recovered (adult-5? (A-5?); USNM 239967, pl. 2, fig. 9) has a relatively large horn-shaped posterodorsal node (the distal end of the node is broken on the only specimen), a rudimentary velar ridge, and a restriction of the reticulation to an area on the lateral surface ventral to the midheight. Some reticulation may also be present on the anterodorsal and the horn-shaped posterodorsal node. In the next growth stage, adult-4, the velar ridge is more strongly defined and the distal end of the horn-shaped posterodorsal node is spinose. During the rest of ontogeny, the velar ridge becomes increasingly well defined and the number of spinose individuals composing the populations decreases. However, many of the adult and larger preadult specimens have pointed or conical posterodorsal nodes. A complete gradation exists from hemispherical and rounded to pointed and conical. Additionally, the posterodorsal nodes of the adult and larger preadult specimens are smaller and not as horn shaped as the earlier stages. These observations are consistent with 
TABLE 6.-Statistical summary of measurements (in $\mathrm{mm}$ ) for Warthinia nodosa from USGS colln. No. $7468-C O$, from the Clays Ferry Formation

\begin{tabular}{|c|c|c|c|c|c|c|c|}
\hline \multirow{2}{*}{ Instar } & \multirow{2}{*}{$\begin{array}{c}\text { No. of } \\
\text { specimens }\end{array}$} & \multicolumn{3}{|c|}{ Length } & \multicolumn{3}{|c|}{ Height } \\
\hline & & Mean & Minimum & Maximum & Mean & Minimum & Maximum \\
\hline Adult & 3 & 0.508 & 0.504 & 0.510 & 0.314 & 0.312 & 0.316 \\
\hline $\mathrm{A}-1$ & 19 & .470 & .460 & .485 & .290 & .277 & .309 \\
\hline$A-2$ & 10 & .440 & .435 & .447 & .278 & .265 & .290 \\
\hline A-3 $=$ & 13 & .417 & .405 & .430 & .296 & .246 & .302 \\
\hline$A-4$ & 3 & .389 & .378 & .398 & .239 & .233 & .246 \\
\hline A-? & 1 & .340 & ---- & ---- & .202 & -..- & -..- \\
\hline
\end{tabular}

those made by Guber (1963, p. 46), who found that among 500 Richmondian (late Late Ordovician) specimens studied, only the preadult individuals had spinose nodes.

Because of the discrepancy in the dimensions of the right and left valves, the allometric equation was calculated for the entire population and then for each of the valves separately. In all valves, the results were extremely similar and growth approached linearity. The allometric equation for the left valves is height $=0.627$, length $=1.012, r=0.904$.

Discussion.-Warthinia nodosa closely resembles several species of Warthinia from the Maquoketa Shale of Missouri: However, W. verrucosa (Kay, 1940, of Keenan, 1951) differs from $W$. nodosa by having a more prominent punctate velar ridge and a sharp, posteriorly directed spine on the anterodorsal node of the adults; $W$. insolens (Keenan, 1951) differs by having a large spinose posterodorsal node in adults; and $W$. binoda (Keenan, 1951) differs by having the anteroventral node suppressed or lacking in adults. Warthinia saccula (Burr and Swain, 1965) from the Maquoketa of Iowa is very similar to $W$. nodosa but is more coarsely punctate, and the posterodorsal node of adults is large, elliptical, and nonspinose. A single pyritized specimen of Warthinia recovered from USGS colln. 7468-CO resembled illustrations of $W$. saccula given by Burr and Swain (1965) because of the coarseness of preservation; unfortunately, the extremely delicate valve was inadvertently destroyed in an attempt to clean it. The figures of $W$. nodosa shown by Burr and Swain (1965) are at too low a magnification to be sure of the specific identification but seem to resemble $W$. binoda more than $W$. nodosa. This reference is therefore questioned in our synonymy. The holotype and only specimen (Kay, 1940, p. 260) of Kiesowia verrucosa Kay, 1940, from the Ion Dolomite Member of the Decorah Formation in Minnesota has not been seen by us; it is not certain from Kay's description and figures (Kay, 1940, pl. 32, figs. 39, 40) whether this specimen is conspecific with those identified by Keenan (1951, p. 569-570) as $K$. verrucosa, which are here transferred to Warthinia.

Schmidt (1941) erected two subspecies for Warthinia nodosa, Warthinia nodosa paupera (Schmidt, 1941) and Warthinia nodosa nodosa (Ulrich, 1890). The former subspecies was initiated for the typical three-node form and the latter, for the four-node variant described by Ulrich (1890) and illustrated in this report. In populations that include the quadrinodose variants (only two collections, USGS colln. 7471-CO and 7468-CO), a complete morphologic gradation exists between those

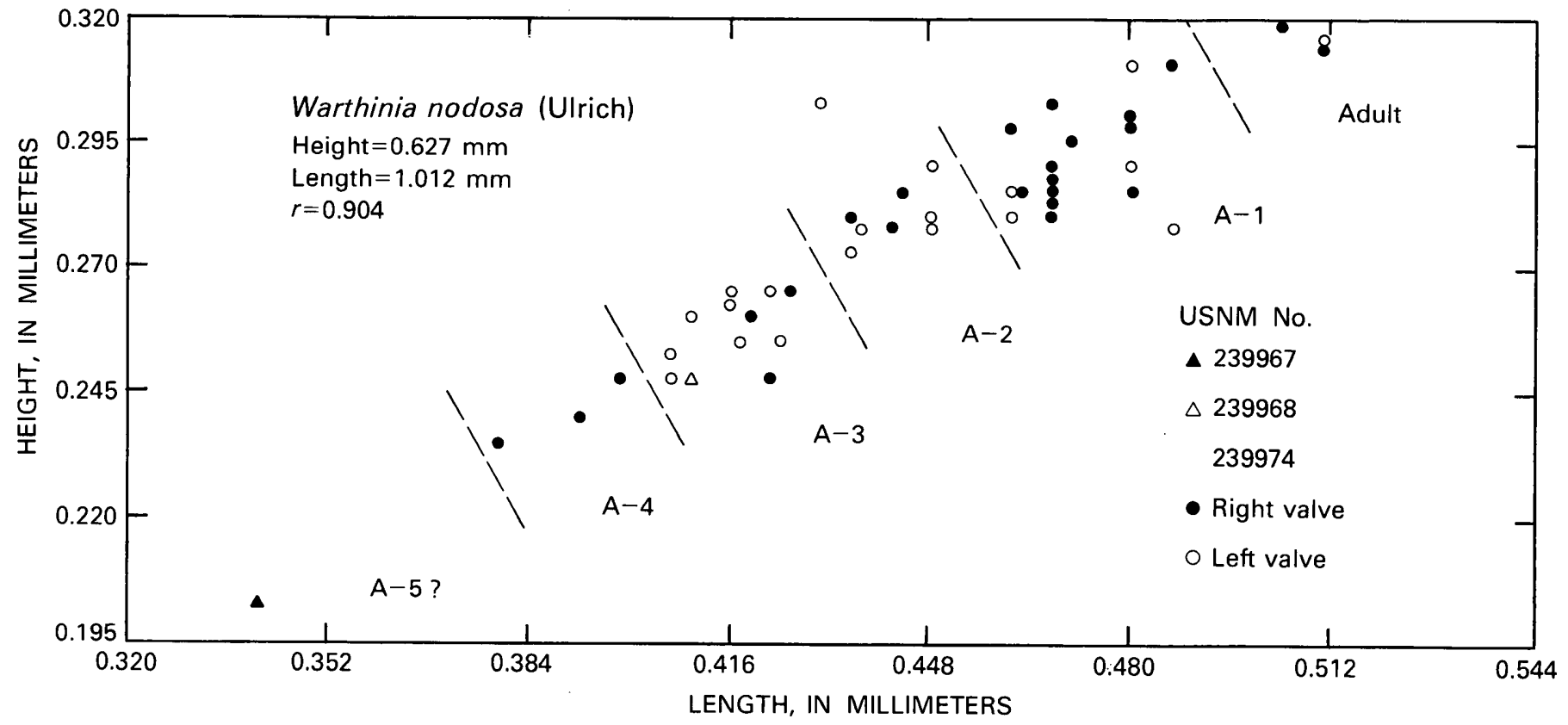

FIGURE 13. - Size-dispersion diagram for 48 specimens of Warthinia nodosa from the Clays Ferry Formation at Sadieville. All specimens are from USGS 7468-CO. 
specimens having three nodes and those having four. Therefore, the two forms cannot be separated as distinct taxa. Variable noding in the Holocene cytherid ostracode, Cyprideis torosa (Jones, 1850), has been demonstrated by several investigators (Kilenyi, 1972; Vesper, 1975) and is thought to be induced by reductions in salinity. A similar ecologic mechanism may be responsible for the variation in number of nodes observed in Warthinia nodosa.

Types. - Lectotype, USNM 41552a (pl. 1, figs. 13-15); paralectotype, USNM 41552b; figured hypotypes, USNM 239967, 239968, 239969, 239972, 239973, 271014; unfigured hypotypes, USNM 239970, 239971, 239974 (46 specimens).

Occurrence. - Warthinia nodosa was found in both the Lexington Limestone (Millersburg, Curdsville, Tanglewood, and Grier) and the Clays Ferry Formation, in rocks of Kirkfieldian to Edenian Age.

Four hundred and sixty-nine specimens were recovered from the following five USGS localities and $19 \mathrm{col}-$ lections: Nicholasville 1, 5899-CO (15); Dry Fork Road, 7039-CO (1), 7040-CO (2), 7041-CO (2), 7043-CO (3), 7056-CO (2), 7071-CO (2), 7079-CO (1); Sadieville C, 7454-CO (37), 7455-CO (10), 7456-CO (2), 7461-CO (1), 7467-CO (62), 7468-CO (75), 7471-CO (249), 7472-CO (1), 7478-CO (2); Switzer A, D1117-CO (1); Gratz A, D1312-CO (1).

This species has also been reported from the Edenian through Richmondian of the Cincinnati area (Bassler and Kellett, 1934), the Upper Ordovician English Head and Vaureal Formations of Anticosti Island, Quebec, Canada (Bassler, 1927; Copeland, 1970), the Richmondian Maquoketa Shale of Iowa (Spivey, 1939) and the Middle Ordovician Dubuque Formation of Minnesota (Burr and Swain, 1965).

\section{Genus PARENTHATIA Kay, 1940}

Type species.-Moorea punctata Ulrich, 1894

Parenthatia sadievillensis n. sp.

Plate 2, figures 2-8

Diagnosis. -Parenthatia with ridge surrounding entire lateral surface of valve; area inside ridge, with exception of poorly defined, subcentral raised area, is coarsely punctate.

Description.-Valves amplete, elongate-suboval in lateral view and apparently equal in size. Greatest length at midheight and greatest height posterior of midlength. Hingeline straight, approximately 70 percent of greatest length, in lateral view partly concealed by dorsal part of surrounding ridge. Ventral margin broadly convex, grades into convex anterior and posterior margins. Anterior margin more sharply rounded than posterior. Cardinal angles obtuse and subequal, anterior more sharply defined than posterior.
Well-formed ridge completely surrounds lateral surface of valve. On anterior and anterodorsal border, surrounding ridge extremely wide, grades into free margin. On other borders, ridge is narrower and, with exception of dorsal border, is separated from slightly outflaring free margin by channel which is narrow on ventral and wide on posterior border. Surface of posterior channel covered by fine irregular ridges. Slight, poorly defined indentation on dorsal part of ridge, approximately 28 percent of distance from anterodorsal cardinal angle, may represent $\mathrm{S} 2$.

Central part of valves, with exception of poorly defined elongate subcentral area, depressed below crest of surrounding ridge. Surface of depressed area coarsely punctate; raised central swelling not punctate. Neither hingement nor sexual dimorphism observed.

Measurements. - The length and height of the holotype and 15 paratypes are given in millimeters in table 7.

TABLE 7.-Measurements (in $\mathrm{mm}$ ) of 16 specimens of Parenthatia sadievillensis from USGS colln. No. 7467-CO, Tanglewood Limestone Member of Lexington Limestone

[Specimen 1, USNM 240035; specimens 2-16, USNM 240036]

\begin{tabular}{|c|c|c|c|}
\hline & Valve & Length & Height \\
\hline \multicolumn{4}{|c|}{ Holotype } \\
\hline $1 \ldots$ & Left__-_-_-_-_-_-_- & 0.428 & 0.277 \\
\hline \multicolumn{4}{|c|}{ Paratypes } \\
\hline 2 ----------- & -_-_-_do_. & 0.447 & 0.302 \\
\hline --_--_--_- & -_-_-_do_. & .457 & .290 \\
\hline 4 & -- - - do do-_- - - - & .398 & .246 \\
\hline 5 & - - - do do- & .441 & .296 \\
\hline 6 & Right__-_. & .428 & .291 \\
\hline 7 & - & .423 & .280 \\
\hline 8 & Left & .449 & .265 \\
\hline 9 _- & Right_. & .425 & .255 \\
\hline 10 & Left & .410 & .252 \\
\hline 11 & - $\mathrm{do}_{-}$ & .428 & .290 \\
\hline 12 & Right___ & .466 & .284 \\
\hline 13 & Left_- & .378 & .243 \\
\hline 14 & - & .391 & .221 \\
\hline 15 & --_-_do_-_- & .378 & .279 \\
\hline 16 & --_- do & .416 & .258 \\
\hline
\end{tabular}

Discussion.-Parenthatia sadievillensis differs from other described species of the genus by having a strongly defined ridge surrounding the entire lateral valve surface and an elongate central swelling. The lectotype of $P$. punctata (Ulrich, 1894), here designated as USNM 41684a (pl. 2, fig. 1), lacks the central swelling and the ridge on the dorsal margin; on $P$. camerata Kay, 1940, the swelling is lacking and the ridge is not well defined and is punctate. Parenthatia reticulata Blumenstengel, 1965 , also lacks the central swelling, although the ridge encircles the valve. The specific name is derived from the type locality, Sadieville, Ky.

Types. - Holotype, an adult left valve, USNM 240035 (pl. 2, fig. 2); figured paratypes, USNM 271016-271018; unfigured paratypes, 13 specimens on one slide, USNM 240036. 
Occurrence. - The holotype and 15 paratypes were found in USGS colln. 7467-CO, from the Tanglewood Limestone Member of the Lexington Limestone, $77 \mathrm{ft}$ above the base of the Sadieville C section, Scott County, Ky. One specimen.(USNM 271018) is from USGS colln. 7468-CO from the Clays Ferry Formation in the Sadieville $\mathrm{C}$ section. This species is not known to occur elsewhere.

\section{Genus GEPHYROPSIS n. gen.}

Type species. -Gephyropsis trachyreticulata n. sp. Species included. - Only the type species.

Diagnosis.-Preplete, subelliptical palaeocope with well-developed rim surrounding entire lateral surface of valve, with exception of anterodorsal sag. Large sigmoidal lobe on middorsal part of valve merges with dorsal part of surrounding rim. Two poorly defined nodes, one dorsal and one ventral, on posterolateral surface of valve.

Discussion.-Gephyropsis is tentatively placed in the Bolliidae because of the occurrence of a marginal rim and nodes, particularly if the bulbous dorsal part of the sigmoidal lobe is viewed as an anterodorsal node. When interpreted in the manner, Gephyropsis has a general similarity to a trinodose Warthinia, although the anterior-posterior orientation is reversed. The reticulation on the nodes of both these genera adds to the resemblance. However, although the two genera may be related, the preplete outline and sigmoidal lobe of Gephyropsis are unlike the corresponding features in Warthinia.

The generic name is derived from the Greek "gephyra," meaning "bridge," and the suffix "-opsis," meaning "having the appearance of, like," in reference to the bridgelike manner in which the sigmoidal lobes of the opposing valves abut against each other dorsally. The gender is feminine.

Geologic range. - As yet, this genus is known only from the lower Upper Ordovician (Edenian) of Kentucky.

Gephyropsis trach yreticulata n. sp.

Plate 3, figures 8-12

Diagnosis. - As for genus.

Description. -Valves preplete, equal in size and subelliptical in lateral view. Greatest length at midheight and greatest height in anterior 25 percent of valve. Dorsal margin basically straight but appears indented in anterior 40 percent of valve so that anterior part is inclined toward posterior. Dorsal margin approximately 70 percent of greatest length and slightly epicline, hingeline being incised along its center. Ventral margin convex with strong posterior upswing. Anterior margin broadly convex, posterior margin sharply convex. Cardinal angles obtuse and subequal.
Well-developed ridge circumscribes entire lateral surface of valves; on free margin, ridge is velar in position and is separated from poorly developed marginal ridge by narrow shallow canaliculus. Poorly developed marginal ridge and well-developed velar ridge parallel around the entire free margin. Dorsally, surrounding ridge parallel to hingeline, including indented part.

Lateral surface of valves deeply impressed below surrounding ridge, with exception of sigmoidal lobe and two nodes. Sigmoidal lobe middorsal in position and merges posteriorly with surrounding ridge; its dorsal part is somewhat bulbous. Sigmoidal lobes of opposing valves abut dorsally to form a bridgelike structure in dorsal view. Two wide, poorly defined nodes on posterolateral surface. Nodes vertically aligned, one being dorsal and one ventral. Nodes and dorsal part of sigmoidal lobe coarsely reticulate. Hingement, internal reflection of morphology, and location of S2 not known.

Measurements. - The holotype and only specimen, a carapace, is $0.438 \mathrm{~mm}$ long, $0.268 \mathrm{~mm}$ high, and has a hingeline $0.315 \mathrm{~mm}$ long.

Discussion. - As noted in the discussion of the genus, $G$. trachyreticulata resembles a small, misshapened Warthinia, and as only one specimen has been found, this was at first considered a possibility. However, the sigmoidal lobe of Gephyropsis cannot be derived from any of the nodes of Warthinia by deformation and, although poorly preserved, its preplete outline appears to be original and not due to distortion. The indentation of the hingeline, however, may not be a natural feature. We do not know whether the one small specimen is an adult or juvenile instar, but it is so dissimilar to previously described palaeocopes that its inclusion in an established species as an instar or sexual dimorph is extremely unlikely. Further knowledge of this species must wait upon the discovery of additional specimens. The specific name is derived from the Greek "trachy," meaning "rough," referring to the coarse reticulation of the nodes and sigmoidal lobe.

Types.-Holotype, a complete carapace, USNM 239975.

Occurrence.-Millersburg Member of the Lexington Limestone, USGS colln. 7454-CO, $20 \mathrm{ft}$ above the base of the Sadieville C section (Edenian), Scott County, Ky.

Family RICHINIDAE Scott, 1961

Genus JONESELLA Ulrich, 1890

Type species. -Leperditia crepiformis Ulrich, 1879.

Jonesella gonyloba n. sp.

Plate 3, figures $13-15$

Diagnosis. - Amplete palaeocopids with two large mammelose nodes on the anterodorsal and mid-dorsal 
valve surfaces and large geniculate lobe anterior and ventral of nodes. No velar structures present.

Description. - Valves amplete and subovate in lateral view. Greatest height at midlength and greatest length just dorsal to midheight. Dorsum straight, approximately 60 percent of greatest length. Ventral margin broadly convex, grades into convex anterior and posterior margins. Anterior margin slightly more broadly rounded than posterior. Cardinal angles sharply defined, obtuse, and subequal. Two large oblong nodes along dorsal margin. Larger node anterior and smaller just posterior of midlength; $\mathrm{S} 2$ is between nodes. Low geniculate lobe in anterior part of valve surface, gently rounded in cross section, and anterior to and ventral of nodes. Lobe starts in anterodorsal corner, parallels anterior margin of anterior node, and bends sharply beneath it until it points directly posteriorly, terminating beneath $\mathrm{S} 2$ in subtriangular swelling, apex of triangle pointing dorsally. Nodes, location of S2, and lobe are internally reflected as inverse features. Hingement not observed.

Material. -19 specimens: the holotype, 13 paratypes, and 5 assorted fragments.

Measurements. - The dimensions of the 11 measurable specimens are shown in table 8.

TABLE 8. - Measurements (in $\mathrm{mm}$ ) of 11 specimens of Jonesella gonyloba

[Specimen 1, USNM 239981, USGS colln. No. D1196-CO from the Logana Member of Lexington Limestone; specimens 2-11, USNM 239982, USGS colln. No. 5899-CO from the Curdsville Member of the Lexington Limestone]

\begin{tabular}{|c|c|c|c|c|c|}
\hline & Valve & Length & Height & Hingeline & Comments \\
\hline \multicolumn{6}{|c|}{ Holotype } \\
\hline 1 & Right _-- & 0.714 & 0.498 & 0.432 & Calcareous valve. \\
\hline \multicolumn{6}{|c|}{ Unfigured paratypes } \\
\hline 2 & Left & 0.572 & 0.364 & 0.286 & Phosphatic filling. \\
\hline 3 & Right & .533 & .364 & .260 & Do. \\
\hline 4 & Left & .533 & .377 & .273 & Do. \\
\hline 5 & -_-_do - & .507 & .338 & .260 & Do. \\
\hline 6 & Right & .520 & .338 & .260 & Do. \\
\hline 7 & - do - & .520 & .364 & .247 & Do. \\
\hline 8 & Left & .624 & .390 & .325 & Do. \\
\hline 9 & _._._do _- & .598 & .390 & .364 & Do. \\
\hline 10 & Right _-- & .507 & .325 & .299 & Do. \\
\hline 11 & _-_-_do _ & .559 & .351 & 273 & Do. \\
\hline
\end{tabular}

Discussion. - Poor preservation has severely hindered the study of this new species. Of 16 specimens, only two are calcareous valves. The rest are phosphatic internal casts reflecting various parts of the morphology. The casts do indicate, however, that the two nodes and geniculate lobe are internally reflected.

Jonesella gonyloba greatly resembles $J$. crepidiformis (Ulrich, 1879), the type species of Jonesella, with the ventral part of the "U-shaped" lobe moved anteriorly. This shift in a part of the "jonesellid" lobe causes this species to show a great affinity to members of the
Richinidae, an early and middle Paleozoic family consisting of rimless subovate forms that have two dorsomedian nodes. For this reason, Jonesella, considered as of uncertain familial affinities in the "Treatise on Invertebrate Paleontology" (Moore, 1961, p. Q132), is here provisionally placed in the Richinidae. The specific name is derived from the Greek "gony" meaning "knee" with reference to the knee-shaped lobe on the anterolateral surface of the valves.

Types. - Holotype, a right valve, USNM 239981; unfigured paratypes, USNM 239982 (13 specimens on one slide).

Occurrence. - The holotype of $J$. gonyloba is from $0.5 \mathrm{ft}$ below the top of the Logana Member of the Lexington Limestone, Frankfort East-A section, Franklin County, Ky., USGS colln. D1196-CO. The 13 paratypes are from the top of the Curdsville Limestone Member of the Lexington, Nicholasville 1 section (Denny core), USGS colln. 5899-CO. This species occurs in rocks of Kirkfieldian to Shermanian Age.

Family uncertain

Genus BALLARDINA Harris, 1957

Type species. -Ballardina concentrica Harris, 1957.

Ballardina millersburgia n. sp.

Plate 3, figures 2-7

Diagnosis. - Central part of domicilium depressed; dorsum inflated with indistinct sulcus in anterior half and poorly defined node beneath sulcus in elongate subcentral depression.

Description. - Lateral outline subelliptical, slightly postplete. Anterior and posterior margins smoothly curved, ventral margin gently curved, dorsal margin slightly sinuous. Hingeline straight, about 70 percent of greatest length, concealed in lateral view by inflated dorsum. Greatest length at or below midpoint of valve, greatest height posterior of midlength. Cardinal angles well defined, obtuse, anterior angle greater than posterior. Subcentral part of domicilium an elongate depression in which, just anterior of midlength, is poorly defined node. Depression bordered ventrally by broad ridge which curves dorsally at both ends of valve to merge with inflated dorsum. Dorsum divided by indistinct, short shallow sulcus above node; posterior part of dorsum higher and wider than anterior part. Velar ridge distinct, extends from anterior to posterior cardinal angles, widest ventrally. Poorly defined marginal rim merges with velar ridge at cardinal angles. Subvelar field plane or very weakly channelled. Valve surface apparently finely granulose. Hingement apparently simple tongue and groove. Shell thick, external morphology not clearly reflected internally. Dimorphism not seen. 
Measurements. - Table 9 shows the measurements of the holotype and 12 paratypes; a statistical summary of these measurements is given in table 10.

TABLE 9.-Measurements (in $\mathrm{mm}$ ) of 13 specimens of Ballardina millersburgia from the Millersburg Member of the Lexington Limestone

\begin{tabular}{|c|c|c|c|c|c|c|}
\hline & $\begin{array}{l}\text { USNM } \\
\text { No. }\end{array}$ & $\begin{array}{l}\text { USGS } \\
\text { colln. No. }\end{array}$ & Valve & Length & Height & Hingeline \\
\hline \multicolumn{7}{|c|}{ Holotype } \\
\hline 1 & 239983 & $7455-\mathrm{CO}$ & Left & 0.648 & 0.425 & 0.490 \\
\hline \multicolumn{7}{|c|}{ Figured paratype } \\
\hline 2 & 239984 & $7455-\mathrm{CO}$ & Right _....... & 0.662 & 0.432 & 0.439 \\
\hline \multicolumn{7}{|c|}{ Unfigured paratypes } \\
\hline 3 & 239985 & $7455-\mathrm{CO}$ & Right & 0.663 & 0.454 & 0.482 \\
\hline 4 & 239985 & $7455-\mathrm{CO}$ & Left & .623 & .4 & .425 \\
\hline 5 & 239985 & $7455-\mathrm{CO}$ & - do & .564 & .360 & .396 \\
\hline 6 & 239985 & 7455-CO & ---_do & .684 & .446 & .490 \\
\hline 7 & 239985 & $7455-\mathrm{CO}$ & Right & .562 & .367 & .374 \\
\hline 8 & 239985 & $7455-\mathrm{CO}$ & Left & .570 & .374 & $(1)$ \\
\hline 9 & 239985 & $7455-\mathrm{CO}$ & Right & .614 & .403 & .443 \\
\hline 10 & 239987 & $7454-\mathrm{CO}$ & - & .612 & .418 & .425 \\
\hline 11 & 239987 & $7454-\mathrm{CO}$ & Left & .600 & .410 & .439 \\
\hline 12 & 2399 & $7456-\mathrm{CO}$ & Right & .678 & .446 & .504 \\
\hline 13 & 239986 & $7456-\mathrm{CO}$ & do & .499 & .353 & .353 \\
\hline
\end{tabular}

1 Measurement not obtainable, because of a broken anterior cardinal corner.

Ontogeny. - The lack of sufficient material makes the acquisition of reliable ontogenetic data extremely difficult. However, the smallest specimen yet recovered, an adult-3 (A-3) (fig. 14), has several interesting features, namely, a very poorly defined central depression and lack of a node. In addition, the velar ridge and the sulcus are poorly defined. Although these subdued features might be due to poor preservation of this specimen, the remaining two instars, adult-2 and adult-1, show a steady increase in the development of the central depression, node, sulcus, and velar ridge until the adult condition is attained.

According to the high exponential value for the allometric equations: height $=0.631$; length $=0.896$; growth approaches linearity. High correlation, $r=0.955$, indicates a strong relationship between the points and the equation.

Discussion. - Harris (1957, p. 224) proposed the genus Ballardina for small ostracodes that have an inflated dorsum, a relatively long, straight hinge, and a small anterocentral node defined dorsally and posteriorly by a crescentic sulcus that may be enlarged posteriorly beneath the thickened dorsum; he designated $B$. concentrica Harris, 1957 from the Joins and Oil Creek Formations of Oklahoma as the type species of his new genus. Ballardina millersburgia most closely resembles the holotype of $B$. concentrica (MCZ 4619; pl. 3, fig. 1), but $B$. concentrica has a wider velar ridge, which is restricted in the posterior part of the valve, and a narrower ridge beneath the central depression. The other
TABLE 10.-Statistical summary of measurements (in $\mathrm{mm}$ ) for Ballardina millersburgia from USGS colln. Nos. 7454-CO, 7455-CO, and 7456-CO from the Millersburg Member of the Lexington Limestone

\begin{tabular}{|c|c|c|c|c|c|c|c|}
\hline \multirow{2}{*}{ Instar } & \multirow{2}{*}{$\mathrm{N}$} & \multicolumn{3}{|c|}{ Length } & \multicolumn{3}{|c|}{ Height } \\
\hline & & Mean & Minimum & Maximum & Mean & Minimum & Maximum \\
\hline Adult & 5 & 0.667 & 0.648 & 0.684 & 0.441 & 0.425 & 0.454 \\
\hline$A=1$ & 4 & .614 & .606 & .623 & .410 & .903 & .418 \\
\hline A-2 _....-- & 3 & . 565 & .562 & .569 & .367 & .367 & .374 \\
\hline A-3 & .1 & .499 & --- & ---- & .353 & ---- & ---- \\
\hline
\end{tabular}

species in the genus, $B$. minuta Harris, 1957, and $B$. simplex Harris, 1957, lack the elongate central depression found in B. millersburgia and B. concentrica.

The specific name of Ballardina millersburgia is derived from the Millersburg Member of the Lexington Limestone, its only known occurrence.

Types. - Holotype, an adult? left valve, USNM 239983, from the Millersburg Member of the Lexington Limestone, 22 feet above the base of the Sadieville C section, Scott County, Ky. (USGS colln.7455-CO). Figured paratypes, USNM 239984, 271019, 271020; unfigured paratypes, USNM 239985 ( 7 , specimens, USGS colln. 7455-CO), USNM 239986 (2 specimens, USGS colln. 7456-CO), USNM 239987 (2 specimens, USGS colln. $7454-\mathrm{CO}$ ).

Occurrence. -15 specimens were found in the Millersburg Member (Edenian) of the Lexington Limestone in an interval 20 to $30 \mathrm{ft}$ above the base of the Sadieville C section, from the following USGS collection: 7454-CO (2); 7455-CO (11); 7456-CO (2).

\section{Superfamily HOLLINACEA Swartz, 1936 Family TETRADELLIDAE Swartz, 1936 Subfamily GLOSSOMORPHITINAE Hessland, 1954 Genus CTENOBOLBINA Ulrich, 1890}

Type species. -Beyrichia ciliata Emmons, 1855.

Ctenobolbina ventrispinifera $n$. sp. Plate 4, figures 1-14

Diagnosis.-Ctenobolbina with two well developed sulci, S2 and S3, S1 being represented by shallow reentrant on posterodorsal surface of L1; short spine on L4 of the adults near ventral border. Infravelar antral dimorphism present; heteromorphs have wide, deep subvelar channel, and adult tecnomorphs have shallow, narrow channel. Preadult tecnomorphic valves bispinose, one spine middorsal and one midventral.

Description. -Valves amplete to slightly preplete in lateral view, equal in size and subrectangular. Greatest height just anterior of S2 and greatest length just dorsal to midheight. Greatest width coincident with midheight of L3. Dorsum straight, approximately 75 percent of greatest length and slightly epicline. Ventral margin broadly convex. Anterior and posterior margins both 


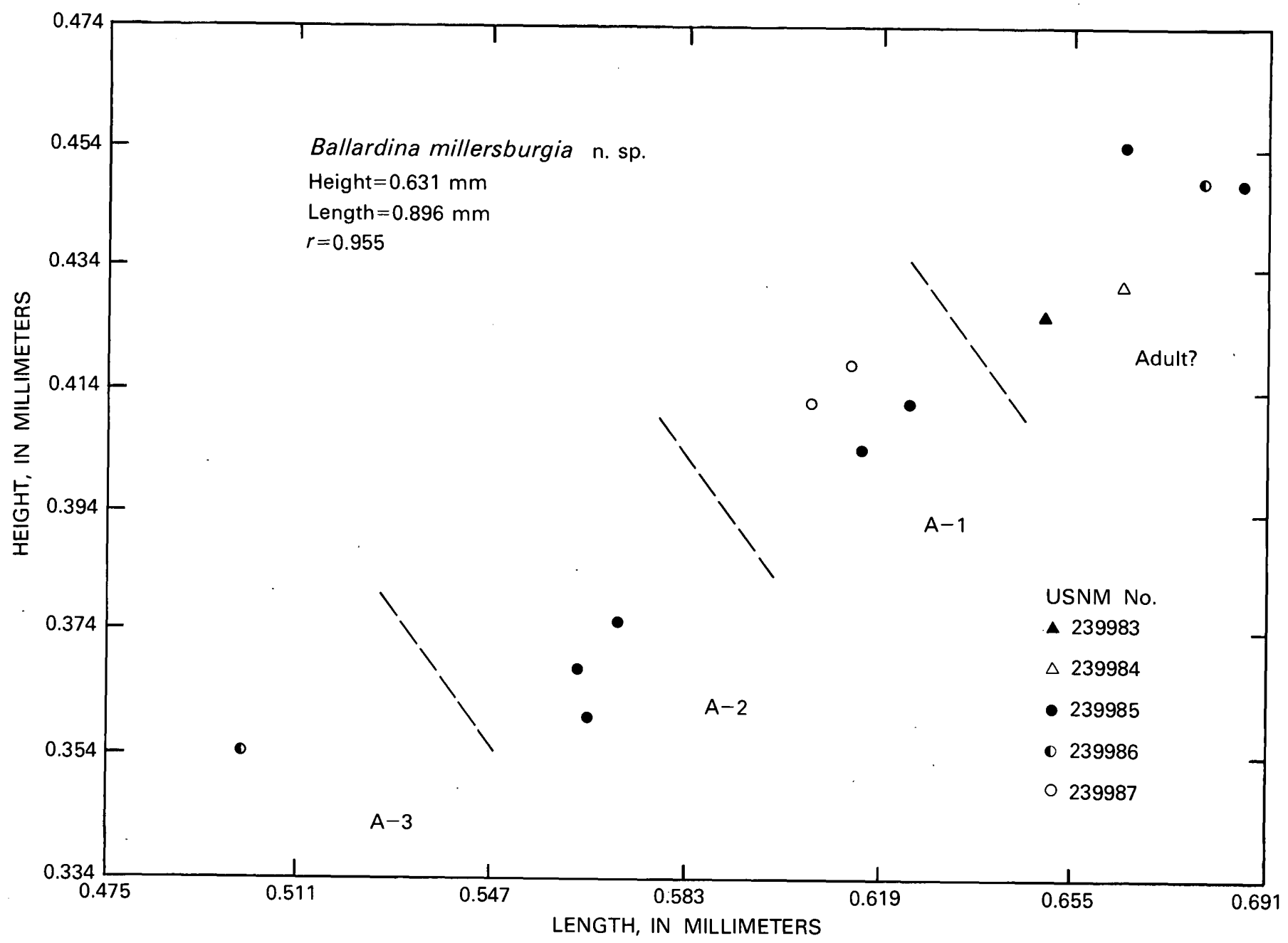

FIGURE 14. - Size-dispersion diagram for 13 specimens of Ballardina millersburgia from the Millersburg Member of the Lexington Limestone at Sadieville. See table 9 for the USGS collection numbers.

convex, anterior being more broadly rounded than posterior. Cardinal angles both obtuse, anterior being greater and more sharply defined than posterior.

L1 bulbous and subrounded; shallow reentrant on posterodorsal part of L1 represents an incipient S1. L2 very poorly developed small lobate extension of L1. L1 and L2 separated from L3 by wide, long, deeply impressed and curving S2, concave toward anterior and flaring dorsally. L3 long and prominent, separated from L4 by narrow, shallow S3. S3 restricted to midpart of valve and does not extend to hinge line. L4 extremely wide and has short spine near its base. All three major lobes connected by poorly defined ventral connecting lobe. Surface of lobes and sulci coarsely papillose, with exception of $\mathrm{S} 2$, which is smooth. In adult tecnomorphs, narrow, concave velar frill extends from ventral portion of anterior margin across adventral surface to ventral part of posterior margin; subvelar field is narrow canaliculus between inner side of frill and row of marginal spines. In heteromorphs, frill wide, convex with anterior frill funnel on midanterior margin. Velar frill higher on valve flank in heteromorph than in tecnomorph. Heteromorphic infravelar antrum deep, long, and wide; outer antral fence consists of inner surface of velar frill and inner antral fence consists of marginal ridge with superimposed spines. Most specimens carapaces; hingement not determined.

Measurements. - Table 11 gives the measurements of 47 specimens from the Dry Fork Road section, and table 12 is a statistical summary of the measurements.

Ontogeny. - Because of the poor preservation of the specimens, a complete understanding of the smaller preadult stages is difficult. However, the size-dispersion diagram (fig. 15) shows seven growth stages, the adult through adult-6 (A-6). The smallest specimen (A-6) appears to be unisulcate (S2) and is subelliptical in lateral outline, the greatest height being anterior and the area posterior of S2, poorly developed. Two spines are pres- 
TABLE 11.-Measurements (in $\mathrm{mm}$ ) of 47 carapaces (with the exception of USNM 239978, a left valve) of Ctenobolbina ventrispinifera from USGS colln. No. 7053-CO, Millersburg Member of Lexington Limestone

[Specimen 1, USNM 239976; Specimen 2, USNM 239977; Specimen 3, USNM 239978; Specimen 4, USNM 239979; Specimens 5-47, USNM 239980]

\begin{tabular}{|c|c|c|c|c|}
\hline & Length & Height & Hingeline & Comment \\
\hline \multicolumn{5}{|c|}{ Holotype } \\
\hline 1 & 1.079 & 0.689 & 0.806 & Adult tecnomorph. \\
\hline \multicolumn{5}{|c|}{ Figured paratypes } \\
\hline $\begin{array}{l}2 \\
3 \\
4\end{array}$ & $\begin{array}{r}1.118 \\
1.170 \\
.689\end{array}$ & $\begin{array}{r}0.690 \\
.598 \\
.403\end{array}$ & $\begin{array}{r}0.845 \\
.936 \\
.572\end{array}$ & $\begin{array}{l}\text { Adult heteromorph. } \\
\text { Do. } \\
\text { Bispinose. }\end{array}$ \\
\hline \multicolumn{5}{|c|}{ Unfigured paratypes } \\
\hline $\begin{array}{r}5 \\
6 \\
7 \\
8 \\
9 \\
10\end{array}$ & $\begin{array}{r}0.858 \\
.745 \\
.962 \\
.845 \\
.832 \\
1.079\end{array}$ & $\begin{array}{r}0.494 \\
.429 \\
.533 \\
.455 \\
.455 \\
.663\end{array}$ & $\begin{array}{r}0.689 \\
.624 \\
.728 \\
.689 \\
.650 \\
.858\end{array}$ & $\begin{array}{l}\text { Bispinose. } \\
\text { Do. } \\
\text { Do. } \\
\text { Do. } \\
\text { Do. } \\
\text { Adult tecnomorph. }\end{array}$ \\
\hline $\begin{array}{l}11 \\
12 \\
13 \\
14 \\
15 \\
16\end{array}$ & $\begin{array}{l}.845 \\
.806 \\
.728 \\
.650 \\
.624 \\
.754\end{array}$ & $\begin{array}{l}.520 \\
.468 \\
.416 \\
.364 \\
.351 \\
.430\end{array}$ & $\begin{array}{l}.715 \\
.546 \\
.650 \\
.520 \\
.520 \\
.507\end{array}$ & $\begin{array}{l}\text { Bispinose. } \\
\text { Do. } \\
\text { Do. } \\
\text { Do. } \\
\text { Do. } \\
\text { Do. }\end{array}$ \\
\hline $\begin{array}{l}17 \\
18 \\
19 \\
20 \\
21 \\
22\end{array}$ & $\begin{array}{r}.611 \\
.429 \\
.715 \\
.702 \\
.936 \\
1.118\end{array}$ & $\begin{array}{l}.390 \\
.247 \\
.416 \\
.429 \\
.455 \\
.585\end{array}$ & $\begin{array}{l}.507 \\
.377 \\
.598 \\
.585 \\
.728 \\
.806\end{array}$ & $\begin{array}{l}\text { Do. } \\
\text { Do. } \\
\text { Do. } \\
\text { Do. } \\
\text { Do. } \\
\text { Adult tecnomorph. }\end{array}$ \\
\hline $\begin{array}{l}23 \\
24 \\
25 \\
26 \\
27 \\
28\end{array}$ & $\begin{array}{r}.910 \\
1.027 \\
.793 \\
.845 \\
.988 \\
1.040\end{array}$ & $\begin{array}{l}.546 \\
.572 \\
.442 \\
.455 \\
.585 \\
.585\end{array}$ & $\begin{array}{l}.741 \\
.832 \\
.624 \\
.728 \\
.845 \\
.845\end{array}$ & $\begin{array}{l}\text { Bispinose. } \\
\text { Do. } \\
\text { Do. } \\
\text { Do. } \\
\text { Do. } \\
\text { Do. }\end{array}$ \\
\hline $\begin{array}{l}29 \\
30 \\
31 \\
32 \\
33 \\
34\end{array}$ & $\begin{array}{r}.793 \\
.832 \\
1.079 \\
1.157 \\
.988 \\
.871\end{array}$ & $\begin{array}{l}.494 \\
.455 \\
.585 \\
.650 \\
.520 \\
.494\end{array}$ & $\begin{array}{l}.533 \\
.650 \\
.845 \\
.845 \\
.780 \\
.741\end{array}$ & $\begin{array}{l}\text { Do. } \\
\text { Do. } \\
\text { Bispinose. } \\
\text { Adult heteromorph. } \\
\text { Bispinose. } \\
\text { Do. }\end{array}$ \\
\hline $\begin{array}{l}35 \\
36 \\
37 \\
38 \\
39 \\
40\end{array}$ & $\begin{array}{l}.988 \\
.728 \\
.871 \\
.715 \\
.702 \\
.637\end{array}$ & $\begin{array}{l}.533 \\
.429 \\
.494 \\
.429 \\
.416 \\
.377\end{array}$ & $\begin{array}{l}.780 \\
.611 \\
.715 \\
.572 \\
.585 \\
.546\end{array}$ & $\begin{array}{l}\text { Do. } \\
\text { Do. } \\
\text { Do. } \\
\text { Do. } \\
\text { Do. } \\
\text { Do. }\end{array}$ \\
\hline $\begin{array}{l}41 \\
42 \\
43 \\
44 \\
45 \\
46 \\
47\end{array}$ & $\begin{array}{l}.546 \\
.650 \\
.559 \\
.897 \\
.897 \\
.884 \\
.559\end{array}$ & $\begin{array}{l}.325 \\
.364 \\
.312 \\
.494 \\
.559 \\
.481 \\
.312\end{array}$ & $\begin{array}{l}.481 \\
.572 \\
.481 \\
.689 \\
.728 \\
.715 \\
.494\end{array}$ & $\begin{array}{l}\text { Do. } \\
\text { Do. } \\
\text { Do. } \\
\text { Do. } \\
\text { Do. } \\
\text { Do. } \\
\text { Do. }\end{array}$ \\
\hline
\end{tabular}

ent on each valve, one ventral and the other middorsal. The spines on the already well-developed lobe that is to become L3 are posteriorly directed. There is a slight marginal rim, but the marginal spines are not distinct.
TABLE 12.-Statistical summary of measurements (in $\mathrm{mm}$ ) for Ctenobolbina ventrispinifera from USGS colln. No. 7053-CO, Millersburg Member of Lexington Limestone

\begin{tabular}{|c|c|c|c|c|c|c|c|}
\hline \multirow{2}{*}{ Instar } & \multirow{2}{*}{$\begin{array}{l}\text { No. of } \\
\text { specimens }\end{array}$} & \multicolumn{3}{|c|}{ Length } & \multicolumn{3}{|c|}{ Height } \\
\hline & & Mean & Minimum & Maximum & Mean & Minimum & Maximum \\
\hline Adult & 6 & 1.120 & 1.079 & 1.170 & 0.639 & 0.585 & 0.689 \\
\hline A-1 & 9 & .950 & .897 & 1.079 & .553 & .920 & .585 \\
\hline A-2 & 14 & .851 & .793 & .936 & .475 & .442 & .520 \\
\hline A-3 & 9 & .721 & 689 & .754 & .422 & .403 & .430 \\
\hline $\mathrm{A}-4$ & 5 & .634 & .611 & .650 & .369 & .351 & .390 \\
\hline $\mathrm{A}-5$ & 3 & .555 & .546 & .559 & .316 & .312 & .325 \\
\hline$A-6 ?$ & 1 & .429 & -- & ---- & .247 & --.- & ---- \\
\hline
\end{tabular}

In the next two instars, $\mathrm{A}-5$ and $\mathrm{A}-4, \mathrm{~S} 1$ becomes evident on the posterodorsal surface of $\mathrm{L} 1$, and distinct spines appear along the contact margin. In all other ways, the specimens resemble A-6.

S3 first starts to develop in A-3 (USNM 239979, pl. 4, figs. 9,10 ), although it is not very well formed. In addition to the development of S3, the posterior part of the valve begins to elongate, and the lateral outline starts to change from subelliptical to subrectangular.

Throughout the rest of the ontogeny, the A-2 through A-1 (USNM 271023, pl. 4, fig. 5), the degree of impression of S3 and the elongation of the valve progressively increase. The addition of velar structures and the loss of the dorsal spines, however, do not take place until the adult stage is attained (USNM 239976-239978, pl. 4, figs. $6-8,11-14)$. Therefore, only the preadult stages are bispinose.

Growth, as defined by the allometric equation height $=0.562$, length $=0.931$, approaches linearity. The points closely correlate with the equation, with an $r$ value of 0.967 .

Discussion.-As is clearly evident from the illustrations (pl. 4, figs. 8-10, 12-14), the specimens of $C$. ventrispinifera have been greatly damaged by the growth of pyrite crystals. This damage has obliterated some features and has introduced uncertainty into the interpretation of others, most notably the incipient S1. However, the presence of this poorly defined structure on most of the specimens was felt to outweigh the effects of poor preservation.

Ctenobolbina ventrispinifera most closely resembles the type species of Ctenobolbina, C. ciliata (Emmons, 1855). The major difference is the occurrence of a short spine on the ventral part of L4 of $C$. ventrispinifera. Some specimens of $C$. ciliata from the Edenian of the Cincinnati area also have a short spine or spine base, but on $C$. ciliata, the spine is only on L3 and never on L4. Ctenobolbina ciliata parva Kirk, 1928, from the Catheys Limestone of Tennessee also has a spine on L3 rather than on L4.

Preadult specimens of $C$. ventrispinifera closely resemble the holotype of $C$. bispinosa Ulrich, 1890 . However, if $C$. bispinosa is a juvenile instar of another 


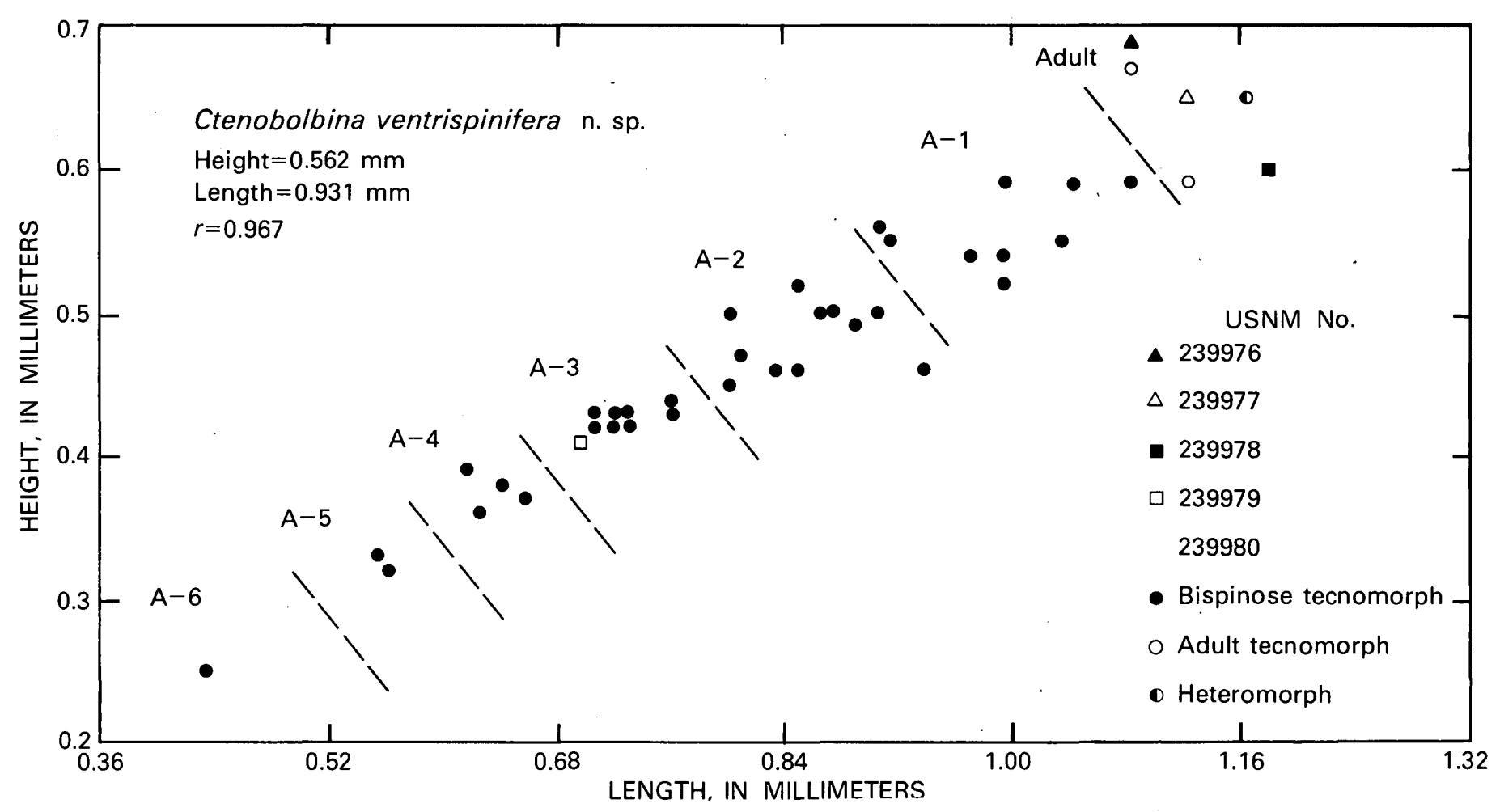

FIGURE 15. - Size-dispersion diagram for 47 specimens of Ctenobolbina ventrispinifera from the Millersburg Member of the Lexington Limestone at Dry Fork Road. All specimens are from USGS 7053-CO.

species of Ctenobolbina, that species is most probably $C$. ciliata or C. alata Ulrich, 1890, as these taxa occur together (Bassler and Kellett, 1934).

The genus Ctenobolbina is here included in the subfamily Glossomorphitinae, as suggested by Schallreuter (1966b, p. 854.)

The specific name of $C$. ventrispinifera refers to the posteroventral spines found on all adult specimens.

Types. - Holotype, an adult tecnomorphic carapace, USNM 239976; figured paratypes, USNM 239977-239979, 271021-271023; unfigured paratypes, USNM 239980 ( 57 specimens on one slide). All types are from the Millersburg Member (Edenian) of the Lexington Limestone, Dry Fork Road section, 31 feet above the 823-ft bench mark, Clark County, Ky., USGS colln. 7053-CO.

Occurrence. - Two hundred and sixty-eight specimens were recovered from the following eight stratigraphic sections and 24 USGS collections: Ford-Boonesboro Road, 6945-CO (1); Dry Fork Road, 7039-CO (5), 7041-CO (4), 7047-CO (1), 7050-CO (7), 7053-CO (167), 7054-CO (13), 7055-CO (10), 7056-CO (5), 7059-CO (5), 7060-CO (2), 7061-CO (2), 7062-CO (3), 7068-CO (5),
7071-CO (2), 7079-CO (1); Kentucky Route 89, 7312-CO (8); Winchester Reference Section B, 7318-CO (4); U.S. Route 227, 7325-CO (12); Sadieville C, 7456-CO (3), 7460-CO (1), 7462-CO (1); Switzer A, D1115-CO (2); Gratz A, D1301-CO (4).

Ctenobolbina ventrispinifera occurs in the Lexington Limestone (Grier, Tanglewood, Millersburg, and Strodes Creek) and in the Clays Ferry Formation; it is Shermanian and Edenian in age. It is not known outside the stratigraphic units reported here.

\section{Subfamily uncertain \\ Genus CERATOPSIS Ulrich, 1894}

1890. Ceratella Ulrich, p. 113, nomen nudum [not Ceratella Gray, 1869].

1894. Ceratopsis Ulrich, p. 675-676.

1908. Ceratopsis Ulrich. Ulrich and Bassler, p. 308.

1909. Ceratopsis Ulrich. Bonnema, p. 39.

1915. Ceratopsis Ulrich. Bassler, p. 198.

1934. Ceratopsis Ulrich. Bassler and Kellett, p. 242 (see for a complete synonymy prior to 1934).

1934. Ceratopsis Ulrich. Kay, p. 340.

1937. Ceratopsis Ulrich. Öpik, p. 25.

1941. Ceratopsis Ulrich. Schmidt, p. 44-46.

1949. Ceratopsis Ulrich. Hessland, p. 329-331. 
1951. Ceratopsis Ulrich. Kesling, p. 108.

1953a. Ceratopsis Ulrich. Henningsmoen, p. 216.

1961. Ceratopsis Ulrich. Moore, ed., p. Q151-Q152.

1975. Ceratopsis Ulrich. Warshauer, p. 443-445.

Type species.-Beyrichia chambersi Miller, 1874, by original designation, Ulrich, 1894, p. 676.

Species included.-Ceratopsis asymmetrica n. sp. Ceratopsis brittanica $\mathrm{Sp}$ jeldnaes, 1963.

Beyrichia (Ceratopsis) duftomensis Reed, 1910.

Ceratopsis fimbriata $\mathrm{n}$. sp.

Ceratopsis intermedia Ulrich, 1894.

Beyrichia oculifer Hall, 1871.

Beyrichia quadrifida Jones, 1891.

Ceratopsis chambersi var. robusta Ulrich, 1894.

Diagnosis. - "A subquadrate quadrilobed palaeocopid with L1 modified into a dorsally directed fimbriate spine; infravelar antral dimorphism present, tecnomorph with a narrow concave frill, heteromorphs with a wide convex frill." (Warshauer, 1975, p. 445).

Discussion.-As currently understood, the genus Ceratopsis comprises preplete quadrilobate palaeocopid ostracodes with velar dimorphism, and with L1 modified into a fimbriate spine (speral process of Jaanusson, 1957 , p. 190), which is free-standing and projects above the hingeline in lateral view. These criteria exclude from the genus all but the nine species listed above of the approximately 20 species that at one time or another have been classified as Ceratopsis.

The inclusion of Ceratopsis in the subfamily Ctenonotellinae of the Ctenonotellidae by Warshauer (1975, p. 445) was done on the belief that the lateromarginal flange on adult specimens of the type species, C. chambersi (Miller, 1874), was not a true histium. However, examination of all other members of the genus shows this interpretation to be erroneous, as histial structures occur in each of them. As a result of this examination, the "lateromarginal flange" is now reinterpreted as a subdued histial structure, which necessitates the removal of Ceratopsis from the Ctenonotellidae.

Recently, Schallreuter (1966b) and Jaanusson (1966) independently published taxonomic revisions of the family Tetradellidae. Each author established subfamilial classifications completely unlike that of the other. We feel, therefore, that the subfamilial classification of the tetradellids is still in a state of flux, and we do not wish to use either of the 1966 classifications. As further refinement of the family is beyond the scope of the present study, it will suffice to say that Ceratopsis, because of its velar dimorphism, histial structures, and quadrilobate valves is a member of the family Tetradellidae.

Since its original description, the number of species included in Ceratopsis has waxed and waned. Ulrich (1894, see 1897, p. 675-676) characterized his new genus as having a fimbriate postdorsal (now considered anterodorsal) process and included the following species in Ceratopsis: Beyrichia chambersi Miller, 1874 (the type species); Beyrichia hastata Barrande, 1872; Ceratopsis intermedia Ulrich, 1894; Beyrichia oculifera Hall, 1871; and Ceratopsis chambersi var. robusta Ulrich, 1894. Ulrich here introduced the binomen $C$. oculifera for Hall's species, which Hall $(1871$, p. 28) had spelled without the final "a." Later, Ulrich and Bassler (1908, p. 308) added Beyrichia (Ctenobolbina) rostrata Krause, 1892, and Beyrichia quadrifida Jones, 1891, to the species included in Ceratopsis without essentially changing the description of the genus. Bonnema (1909, p. 39-42) suggested that the fimbriate process was anterior rather than posterior in position and added Ceratopsis schmidti Bonnema, 1909, and Ctenobolbina rostrata var. cornuta Krause, 1896, to the genus. Reed (1910, p. 217-218) described Beyrichia (Ceratopsis) duftonensis, a species that has been overlooked by most later workers.

Kay (1934, p. 340-341) considered the specimens from the Decorah Shale of Minnesota described as $C$. chambersi (Miller, 1874) by Ulrich (1894, see 1897) to be misidentified and referred them to C. quadrifida (Jones, 1891) but did not describe any new species of Ceratopsis. Öpik (1937, p. 25-28), working with Ordovician ostracodes from Estonia, added the following new species to Ceratopsis: C. platyceras Öpik, 1937; C. perpunctata Öpik, 1937; and C. perpunctata prominens Öpik, 1937. He also included Ctenobolbina rostrata cornuta Krause 1896, as did Bonnema, but he considered Bonnema's species Ceratopsis schmidti to be a junior synonym of Beyrichia obliquejugata Fr. Schmidt, 1858. Opik (1937, p. 25) also noted that the Estonian species showed velar dimorphism, unlike the American species, which at that time were not known to be dimorphic. Schmidt (1941, p. 44-46) critically reviewed Kay's assignment of Ulrich's specimens of $C$. chambersi to $C$. quadrifida, considered that Beyrichia rostrata Krause belonged to Tetradella rather than Ceratopsis, and suggested that $C$. duftonensis Reed might be synonymous with C. obliquejugata Schmidt. He also (Schmidt, 1941, p. 47-48) redescribed Ceratopsis hastata (Barrande, 1872).

Until 1949, species had been added to the genus Ceratopsis, but in that year, Hessland (1949, p. 295-297), noting that some of the species included in Ceratopsis have an adnate bulb on L1 rather than a free- 
standing spine, proposed the new genus Glossopsis, in which he included Ceratopsis schmidti Bonnema, 1909, Ceratopsis bocki Öpik, 1935, Ceratopsis perpunctata Öpik, 1937, and questionably Beyrichia obliquejugata Fr. Schmidt, 1858, as well as 10 new species. Hessland (1949, p. 329-337) also rediagnosed and discussed Ceratopsis and described one new species, C. grandispinosa Hessland, 1949. Then Henningsmoen (1953a, p. 204-205) made the genus Sigmoopsis, with Ceratopsis platyceras Öpik, 1937, as type species, for species with a sigmoidal S2, sausagelike L3, and a carinal (=histial) structure showing dimorphism. In addition to the type species; Henningsmoen (1953a, p. 205) included in Sigmoopsis the following species previously assigned to Ceratopsis: Beyrichia obliquejugata Schmidt, 1858; Ceratopsis perpuncta [sic] Öpik, 1937; C. perpuncta [sic] prominens Öpik, 1937; Beyrichia (Ctenobolbina) rostrata Krause, 1892; Ctenobolbina rostrata cornuta Krause, 1896; and Ceratopsis schmidti Bonnema, 1909. In discussing Ceratopsis, Henningsmoen (1953a, p. 216) predicted that dimorphism, if found, would be in the velar structure. Sarv (1959, p. 141) included Ceratopsis regalis Neckaja, 1950, in his new genus Pseudotallinnella, and Jaanusson (1957, p. 385) placed Ceratopsis bicornis Neckaja, 1953, in Polyceratella Öpik, 1937. Thus, by 1959 , most European species assigned to Ceratopsis had been placed in other genera.

Most recently, Pribyl (1975, p. 12-14) has proposed the new genus Hastatellina, with the type species Beyrichia hastata Barrande, 1872, for bisulcate species with a distinct speral process and a weak velum in tecnomorphs but a histium in heteromorphs. Pribyl (1975, p. 14) included in Hastatellina the following species: Ceratopsis grandispinosa Hessland, 1949; Hastatellina posthastata Přibyl, 1975 (=Ceratopsis hastata Schmidt, 1941 non Beyrichia hastata Barrande, 1872); and $H$. normandiensis Pribyl, 1975. With reservations, Pribyl (1975, p. 14) also questionably included Ctenobolbina rostrata cornuta Krause, 1896, and Ceratopsis humilinoda Kay, 1940. Also recently, Warshauer (1975, p. 443-455) has redescribed the type species of Ceratopsis, C. chambersi (Miller, 1874), and demonstrated that the genus has velar dimorphism, as predicted by Henningsmoen (1953a, p.216). Warshauer (1975, p. 446-449) showed that juvenile specimens of $C$. chambersi (A-5) are trilobate rather than quadrilobate and that adult specimens develop a histial structure (termed lateromarginal bend by him). This suggests a close relationship between the type species of Ceratopsis and Hastatellina as described by Pribyl.

Pribyl (1975, p. 14) presumably considered Ceratopsis humilinoda Kay, 1940, as a possible Hastatellina because Kay (1940, p. 257) described his species as being bisulcate. We have not seen Kay's single type specimen; however, its small size (length $0.41 \mathrm{~mm}$ ) suggests that it is a juvenile individual. The bisulcate (trilobate) tecnomorphs of $C$. chambersi described by Warshauer (1975, p. 448-449) are slightly larger; therefore, $C$. humilinoda may be a young molt of a described trisulcate species. Until the species is restudied, $C$. humilinoda should be considered a nomen dubium.

One species that probably should be assigned to Hastatellina rather than Ceratopsis is $C$. trilobis Keenan, 1951. According to Keenan (1951, p. 572, pl. 79 , figs. 42-44), his species is trilobate, with a narrow velum and a fimbriate anterodorsal spine (posterodorsal by Keenan's orientation), but Keenan does not indicate the presence of a histial structure or lateromarginal bend. Topotype specimens deposited by Keenan in the U.S. National Museum of Natural History (USNM 113455) also show no evidence of a histial structure, considered diagnostic of Hastatellina by Pribyl (1975, p. 12). However, of the three type specimens illustrated by Keenan, two are immature individuals, and the holotype (Keenan, 1951, pl. 79, fig. 42) appears to be $1.5 \mathrm{~mm}$ long and also may not be an adult. Most of the topotypes in the U.S. National Museum are also immature specimens; the largest (pl. 5, fig. 18) which lacks the speral process, is $1.3 \mathrm{~mm}$ long. Thus, it is possible that no adult specimens have yet been found, so pending further collection and study of topotype material, this species is regarded as Hastatellina? trilobis (Keenan, 1951).

Henningsmoen (1953b, p. 42-43) tentatively placed his species C.? stoermeri in Ceratopsis but noted that it might be related to his new genus and species $P$ iretopsis donsi Henningsmoen, 1953. From his description and illustrations (Henningsmoen, 1953b, pl. 1, fig. 6, pl. 2, fig. $6)$, this species appears to be more closely related to Piretopsis than Ceratopsis and might be cited as Piretopsis? stoermeri (Henningsmoen, 1953).

Of the nine species here considered to belong in Ceratopsis, two, C. brittanica Spjeldnaes, 1963, and $C$. duftonensis Reed, 1910, occur in Great Britain; the others are North American. The two British species both have the fimbriate speral process of Ceratopsis, and resemble each other in having a sharp or carinate ventral connecting (histial) lobe. However, Spjeldnaes (1963, pl. 36, fig. 7) and Siveter (1978, pl. 1, figs. 5, 6) show $C$. britannica to have a palmate speral process which is fimbriate only on the palmate part, whereas $C$. duftonensis is shown by Siveter $(1978$, pl. 3 , figs. 1,2$)$ to be fimbriate on the shaft of the speral process nearly to L2.

Of the five previously described North American species here considered to belong to Ceratopsis, the type specimens of four are figured on plate 5 . The species omitted is $C$. chambersi (Miller, 1874), the type species 
of Ceratopsis, which has recently been redescribed by Warshauer (1975). Although the type specimen of $C$. chambersi has not been located (Warshauer, 1975, p. 449-450), the material studied by Warshauer (1975, p. 444) came from the same area and stratigraphic horizon as Miller's type and is believed to be representative of this species. As noted by Hessland (1949, p. 329), Ceratopsis intermedia Ulrich, 1894, was inadequately described and never illustrated. However, Ulrich's syntypes (USNM 41500) are in the U.S. National Museum of Natural History; some of these specimens are illustrated on plate 5 , and a revised description based on the type collection and abundant new material is given later in this paper. A few comments on the type specimens of the other species follow below.

The holotype of Ceratopsis oculifera (Hall, 1871) is deposited at the University of California, Berkeley (UCMP 595/33255). It is on a slab of argillaceous limestone $7.17 \mathrm{~cm}$ long and $3.24 \mathrm{~cm}$ wide. The type specimen is indicated by a white paper triangle and by an arrow inked on the surface of the slab and is numbered 595 on two green paper labels and 33255 in ink on the slab. According to Peck (Peck and McFarland, 1954; Peck, written commun., 1976) the number 595 is Whitfield's original number, and 33255 is the type number of the Museum of Paleontology, University of California, Berkeley. The holotype (pl. 5, fig. 1) is an immature tecnomorphic left valve, $1.02 \mathrm{~mm}$ long and $0.57 \mathrm{~mm}$ high, which differs from the original figures of Hall $(1871$, pl. 8, figs. 9, 10) in having a longer, more elliptical speral process that is not completely encircled by the fimbria. In addition to the holotype, the surface of the slab bears several other specimens of $C$. oculifera, of which six have been removed from the slab by Berdan; four of these are illustrated on plate 5, figs. $2-5$. The smallest of these, a tecnomorphic right valve, is $0.85 \mathrm{~mm}$ long and $0.57 \mathrm{~mm}$ high; the largest, also a tecnomorphic right valve, is $1.75 \mathrm{~mm}$ long and $1.05 \mathrm{~mm}$ high. The height was measured from the hingeline to the edge of the velum through S2. No definitely heteromorphic specimens were found in the type collection.

Hall $(1871$, p. 28) stated that his specimens of Ceratopsis oculifera came from "the Hudson-river shales at Cincinnati, Ohio." Fossils associated with $C$. oculifera on the type slab include brachiopods (Zygospira sp.), trilobite fragments, crinoid columnals, and bryozoan fragments. The bryozoans include specimens that Olgerts Karklins (oral commun., 1976) has identified as Batostomella sp., which he considers indicative of the Maysvillian Stage, and probably from the top of the Fairview or the base of the Bull Fork Formation. This agrees with the statements by Bassler (1915, p. 199) and Bassler and Kellett (1934, p. 243) that $C$. oculifera is Maysvillian in age.
The holotype (GSC 17707) of Ceratopsis quadrifida (Jones, 1891) is deposited in the collections of the Geolgical Survey of Canada (Bolton, 1966, p. 96). M. J. Copeland (oral commun., 1975) commented that the type was poorly preserved and difficult to use for comparative purposes but kindly provided a photograph of the specimen (pl. 5, fig. 19). The original illustrations of Jones $(1891$, pl. 11, figs. 9a, 9b) show that the speral process was already broken at the time the species was described; the lack of this diagnostic feature presumably led Bassler and Kellett (1934, p. 243) to query the assignment of $C$. quadrifida to Ceratopsis. However, the configuration of the lobes, especially that of $\mathrm{L} 2$, is typical of Ceratopsis, although fuller understanding of the species must await collection and study of topotype material to determine the form of the speral process. Specimens identified as $C$. quadrifida from southwestern District of Mackenzie, Northwest Territories, Canada, by Copeland (1974, p. 20, pl. 4, fig. 10, pl. 6 , figs. 1, 2, pl. 7, figs. 1-3) appear to have a relatively wide ventral lobe and variable speral process; they also show velar dimorphism.

The species Ceratopsis robusta (Ulrich, 1894) was described by Ulrich (1894, see 1897, p. 677) as coming from "the upper part of the Hudson River shales near Spring Valley, Minnesota, and [it] occurs abundantly in the upper beds of the Cincinnati group at Waynesville and Oxford, Ohio, Richmond and Versailles, Indiana, and many other localities in these states." The holotype of $C$. robusta (USNM 41,335) is labeled as "RichmondNear Spring Valley, Minn.," and is presumably from the Maquoketa Shale. As suggested by Warshauer (1975, p. 451 ), there is some question whether the Ceratopsis from the Richmondian of Ohio and Indiana is conspecific with C. robusta; specimens identified as $C$. robusta in an unnumbered collection from Waynesville, Ohio, in the U.S. National Museum of Natural History appear to lack the distinct lateromarginal bend of the type. The holotype of $C$. robusta (pl. 5, figs. 13-17) is, as shown by Ulrich (1894, see 1897, p. 677, fig. 50) a tecnomorphic carapace with the speral process of the left valve broken at the base. The speral process of the right valve was partly embedded in matrix, so that the fimbria and the complete shape of the process were hidden; Berdan extracted the specimen for photography but has recemented it to the matrix by means of gum tragacanth which is soluble in water, so that it now appears in its original condition. The specimen is $1.82 \mathrm{~mm}$ long and $1.10 \mathrm{~mm}$ high, which is within the size range of adult instars of other species of Ceratopsis. Further evaluation of the specific characters of $C$. robusta must await the study of topotype material to determine the range of variation in this species.

In addition to $C$. chambersi, three other species of 
Ceratopsis, C. fimbriata n. sp., C. intermedia Ulrich, 1894, and C. quadrifida (Jones) of Copeland (1974, pl. 4, fig. 10) show velar dimorphism. Velar dimorphism probably will also be found in other species of Ceratopsis when further study has been made. As noted by Warshauer (1975, p. 452), heteromorphs of Ceratopsis are rare, which may explain why the genus had been considered nondimorphic. In particular, the wide heteromorphic velum may be lost by accidents of preservation, as it tends to break concentrically away from the part of the velum nearest the valves.

The function of the fimbriate speral process of Ceratopsis remains uncertain. Hall $(1871$, p. 28) considered the speral process of $C$. oculifera to represent an eye, a concept implicitly rejected by Ulrich $(1890$, p. $112-114)$, who oriented this species with the spine in a posterior position. In any case, the inclusion of $C$. oculifera in the same genus with $C$. chambersi, the long spinous speral process of which is difficult to interpret as an eye, has led most workers to abandon Hall's conclusion. The speral process is hollow, but its shell, except along the fimbria, is thicker than much of the rest of the valve; consequently, isolated processes are often found that have no valve attached. To judge from silicified, pyritized, and thin sections of calcareous specimens of C. intermedia, the spinelets along the fimbria are hollow at the base but do not appear to have a lumen extending throughout their length and are solid distally. If comfirmed, this observation tends to exclude the possibility that the speral process was a tactile sensory organ.

The anterodorsal position of the speral process makes its use as a stabilizer seem unlikely. The lack of strengthening structural elements on either the inside or the outside of the valves and the tendency of the process to be broken from the valve suggests that it was not used as a ram, or as any form of support, if, for example, the ostracode lay on its back and fed by agitating the water with its appendages to produce a flow of water and food between the valves. Conceivably, the fimbria on the speral process could have been used to clean the setae on the antennules, although this does not seem very probable. R. H. Benson (oral commun., 1976) has suggested that the process could have been sensitive to sound or vibration and might have functioned as an ear rather than an eye. Possibly it was a recoguition symbol, or, alternatively, it may have served no useful purpose. Whether or not the speral process had a function, at least it was not a liability to the animal, as Ceratopsis ranges from the Middle through the Upper Ordovician and may be extremely abundant within its geographic range.

Geologic range.-Middle and Upper Ordovician (Rocklandian(?) to Richmondian) of eastern North
America; Middle and Upper Ordovician (Llandeilian to Longvillian, Caradocian) of Great Britain.

Ceratopsis intermedia Ulrich, 1894

Plate 5, figures 6-12; plate 6, figures 4, 7-10; plate 7, figures 6-9, 17; plate 8 , figures 6,7

1894. Ceratopsis intermedia Ulrich, p. 676.

1908. Ceratopsis intermedia Ulrich. Ulrich and Bassler, p. 308.

1915. Ceratopsis intermedia Ulrich. Bassler, p. 99.

1934. Ceratopsis intermedia Ulrich. Bassler and Kellett, p. 243.

1949. Ceratopsis intermedia Ulrich. Hessland, p. 329.

Diagnosis.-Ceratopsis with erect, ovate, palmate speral process which is flat to concave anteriorly, fimbria extending to base of process. Antrum of equal width on both valves, wide and deep.

Description.-Lateral outline preplete, anterior margin curved, ventral margin gently curved, posterior margin slightly curved. Hingeline long and straight; greatest length below hingeline. L1 developed as erect palmate speral process which protrudes over hingeline in lateral view, flat to slightly concave on anterior face, fimbriate from top to base along lateral edge, fimbria curves slightly posteriorly. Base of process robust. L2 small, sigmoidal, distinctly separated from speral process, ends dorsally in small knob above midheight of valve and below hingeline. L3 straight to slightly concave anteriorly, weakly claviform, protrudes above hingeline in lateral view. L4 flattened at hingeline, concave anteriorly, curves ventrally into ventral histial lobe which connects all four lobes. Sulci wider than lobes, deep, subtriangular in outline. Velum widest anteroventrally, extends from anterior cardinal angle to posteroventral margin and may be slightly flattened marginally in adult tecnomorphs; velum of heteromorphs wide, curved inward toward contact margins and truncated abruptly posteriorly. Subvelar antrum wide, of equal width on both valves. Shell surface smooth.

Measurements. - The lectotype is a tecnomorphic right valve, which is $1.70 \mathrm{~mm}$ long and $1.00 \mathrm{~mm}$ high. Figure 16 shows dimensions of 25 paralectotypes, and table 13 gives a statistical summary of the measurements. Figure 17 and table 14 give the measurements of 22 unfigured hypotypes, and table 15 gives a statistical summary.

TABLE 13.-Statistical summary of measurements (in $\mathrm{mm}$ ) for the lectotype and páralectotypes of Ceratopsis intermedia

\begin{tabular}{|c|c|c|c|c|c|c|c|}
\hline \multirow{2}{*}{ Instar } & \multirow{2}{*}{$\begin{array}{c}\text { No. of } \\
\text { specimens }\end{array}$} & \multicolumn{3}{|c|}{ Length } & \multicolumn{3}{|c|}{ Height } \\
\hline & & Mean & Minimum & Maximum & Mean & Minimum & $\overline{\text { Maximum }}$ \\
\hline $\begin{array}{l}\text { Adult tecno- } \\
\text { morph }\end{array}$ & 8 & 1.70 & 1.60 & 1.80 & 0.99 & 0.95 & 1.05 \\
\hline $\begin{array}{l}\text { Adult hetero- } \\
\text { morph }\end{array}$ & 1 & 1.95 & & & 1.30 & & \\
\hline $\mathrm{A}-1$ & 9 & 1.49 & $\overline{1.45}$ & $\overline{1.53}$ & $\begin{array}{r}1.00 \\
.86\end{array}$ & .83 & .90 \\
\hline $\mathrm{A}-2$ & 7 & 1.36 & 1.30 & 1.40 & .80 & .75 & .85 \\
\hline $\mathrm{A}-3$ & 1 & 1.25 & ---- & --- & .70 & $\ldots$ & --- \\
\hline
\end{tabular}




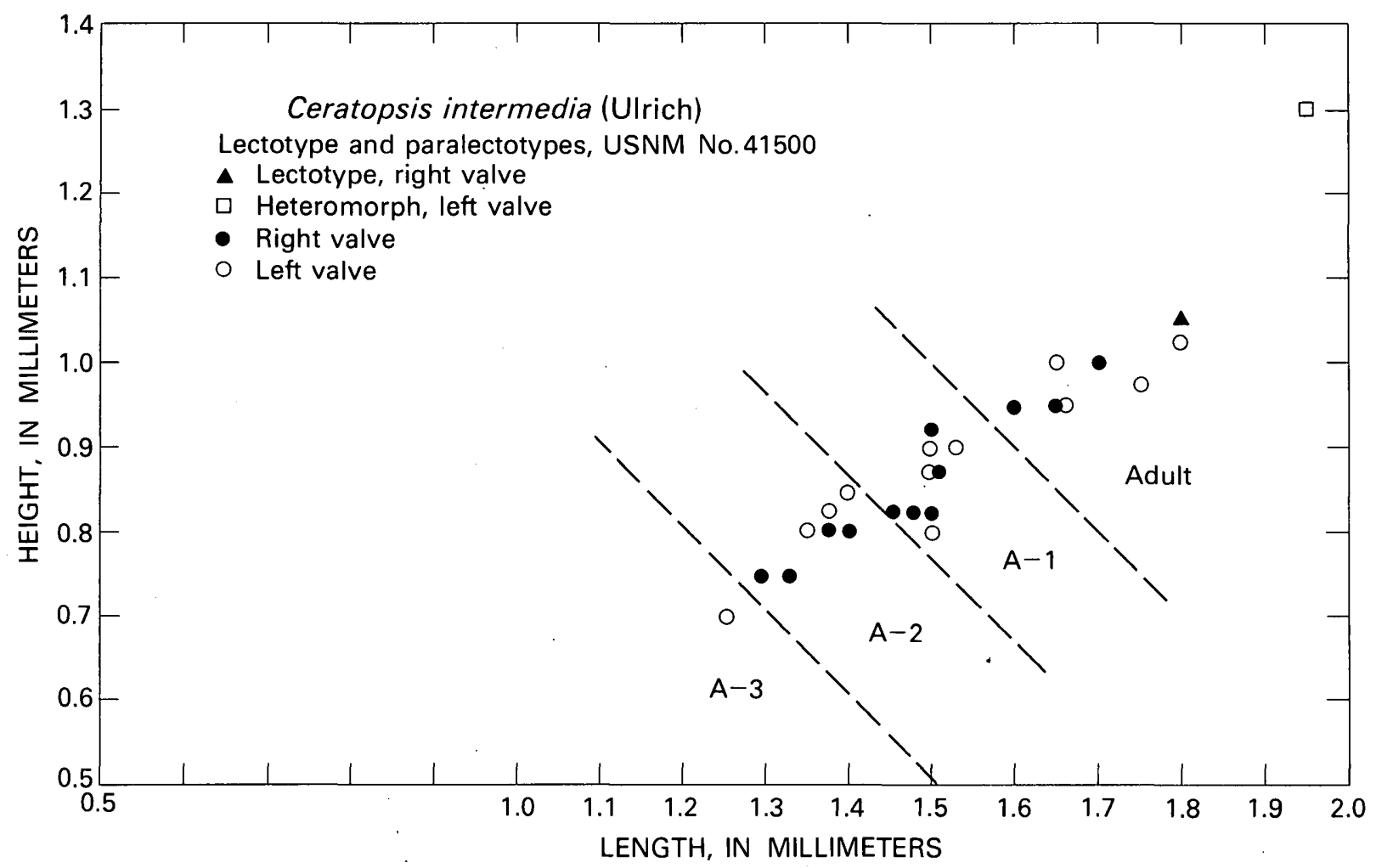

FIgure 16. - Size-dispersion diagram for 25 paralectotypes of Ceratopsis intermedia from the Point Pleasant Tongue of the Clays Ferry Formation, Banklick Creek, Covington, USNM colln. 41500.

TABLE 14.-Measurements (in $\mathrm{mm}$ ) of 22 unfigured hypotypes of Ceratopsis intermedia (USNM 239993) from USGS colln. No. 4191-CO, from the Grier Limestone Member of the Lexington Limestone

\begin{tabular}{|c|c|c|c|c|c|}
\hline & Valve & Instar & Length & Height & Hingeline \\
\hline 1 & Left _._. & A-2 & 1.340 & 0.800 & 1.100 \\
\hline 2 & Right & Adult & 1.640 & .920 & 1.320 \\
\hline 3 & - do & -_-_do _. & 1.680 & .960 & 1.140 \\
\hline 4 & --_-_do & A-2 & 1.360 & .820 & 1.100 \\
\hline 5 & Left & A-1 & 1.500 & .860 & 1.140 \\
\hline 6 & - do & A-1 & 1.520 & .900 & 1.260 \\
\hline 7 & .-_-_-_- & A-2 & 1,380 & .820 & 1.160 \\
\hline 8 & -_do & A-2 & 1.400 & .760 & 1.080 \\
\hline 9 & Left & A-1 & 1.440 & .860 & 1.140 \\
\hline 10 & Right & $\mathrm{A}-2$ & 1.380 & .860 & 1.140 \\
\hline 11 & Left & Adult & 1.600 & .920 & 1.180 \\
\hline 12 & --_-_do _- & $\mathrm{A}-2$ & 1.400 & .820 & 1.180 \\
\hline 13 & Right & A-1 & 1.500 & .820 & 1.200 \\
\hline 14 & do _o _ & $A-1$ & 1.500 & 1.000 & 1.180 \\
\hline 15 & -_- do _ _ & A-1 & 1.500 & .900 & 1.200 \\
\hline 16 & Left & A-3 & 1.280 & .740 & .860 \\
\hline 17 & _._-_do _..... & A-2 & 1.320 & .782 & 1.100 \\
\hline 18 & _-_do _-_-_. & A-2 & 1.402 & .760 & 1.140 \\
\hline 19 & Right & A-4 $\ldots$ & 1.180 & .680 & \\
\hline 20 & Left & A-2 & 1.342 & .780 & 1.100 \\
\hline 21 & Right _-_-----_- & A-1 & 1.420 & .900 & 1.240 \\
\hline 22 & -_-_do - & $\mathrm{A}-3$ & 1.262 & .740 & 1.040 \\
\hline
\end{tabular}

TABLE 15.-Statistical summary of measurements (in $\mathrm{mm}$ ) for Ceratopsis intermedia

\begin{tabular}{|c|c|c|c|c|c|c|c|}
\hline \multirow{2}{*}{ Instar } & \multirow{2}{*}{$\begin{array}{l}\text { No. of } \\
\text { specimens }\end{array}$} & \multicolumn{3}{|c|}{ Length } & \multicolumn{3}{|c|}{ Height } \\
\hline & & Mean & Minimum & Maximum & Mean & Minimum & $\overline{\text { Maximum }}$ \\
\hline Adult & 3 & 1.640 & 1.600 & 1.680 & 0.933 & 0.920 & 0.960 \\
\hline A-1 & 7 & 1.483 & 1.420 & 1.520 & .890 & .820 & 1.000 \\
\hline$A-2$ & 9 & 1.369 & 1.320 & 1.402 & .800 & .760 & .860 \\
\hline $\mathrm{A}-3$ & 2 & 1.270 & 1.262 & 1.280 & .740 & .740 & .740 \\
\hline$A-4$ & 1 & 1.180 & ----- & ----- & .680 & ----- & ------ \\
\hline
\end{tabular}

Ontogeny.-With the exception of the expected changes in absolute size (figs. 16, 17), this species shows an amazing consistency in morphologic features from one instar to the next. The only trend to be delineated from the limited growth data at hand involved the relative dimensions of the speral process. In the youngest stage adults $-4(\mathrm{~A}-4)$ yet recovered that can be assigned to $C$. intermedia, the process is relatively long, narrow, and does not have the palmate shape of that of the adult. It resembles, in a general manner, the elongate type of speral process possessed by adults of $C$. chambersi, the type species of the genus. Throughout ontogeny, the process becomes increasingly shorter, wider, and palmate, although, in any population of adult 


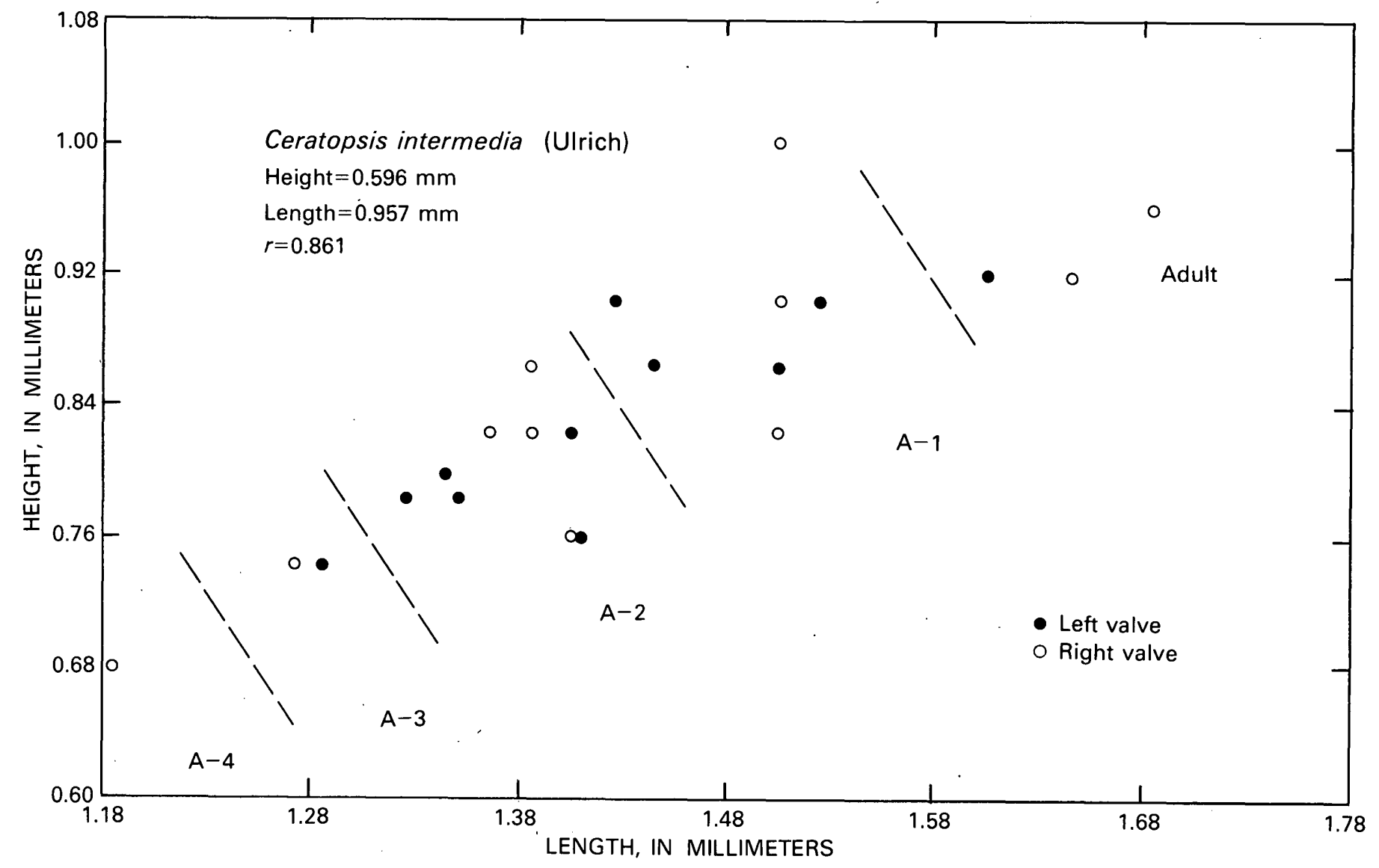

FIGURE 17. - Size-dispersion diagram for 22 hypotypes of Ceratopsis intermedia from the Grier Limestone Member of the Lexington Limestone at Hunters Ferry Road (Valley View B). All specimens are from USGS 4191-CO; USNM 239993.

specimens the morphology of the process can be quite variable.

One collection from the Clays Ferry Formation (USGS colln. 6945-CO) contains small trilobate specimens of Ceratopsis that are $0.45 \mathrm{~mm}$ or less long and $0.25 \mathrm{~mm}$ or less high. Adults of both $C$. intermedia and the new species $C$. asymmetrica occur in this collection, and these specimens are too undifferentiated to assign to either species. The smallest specimens probably represent instars A-5 or A-6; here a suite of small individuals is illustrated (pl. 7, figs. 1-5) because it shows that other species of Ceratopsis besides $C$. chambersi are trilobate in very small instars.

The relative growth of $C$. intermedia, as defined by the allometric equation, is height $=0.596$, length $=0.957$. The data points correlate fairly well to this, $r=0.861$.

Discussion. - As noted by Hessland (1949, p. 329), Ulrich never illustrated Ceratopsis intermedia. Ulrich (1894; see 1897, p. 676) described the species as follows: "A new species, which I propose to call $C$. intermedia, occurs at the base of the Cincinnati formation near Covington, Kentucky. In this the process forms a curved spine on which the fimbria is arranged in a semicircular manner, the effect being very nearly intermediate between that exhibited in $C$. chambersi and $C$. oculifera." As a result of this curtailed description, no specimens were identified as $C$. intermedia between 1894 and approximately 1970 , although the species was referred to in general discussions and lists as indicated in the synonymy. During the late 1960's when the U.S. Geological Survey began a project of restudying the Ordovician faunas of Kentucky, large numbers of Ceratopsis were found in collections from that State. Berdan (1970), having access to Ulrich's types in the U.S. National Museum of Natural History, was able to identify many of these with C. intermedia, so that this name has since appeared in faunal lists on maps and in bulletins connected with this project. Ulrich's type collection (USNM 41500) is here redescribed and specimens from it are illustrated (pl. 5, figs. 6-12) in order to provide a basis for these identifications.

The type collection of Ceratopsis intermedia Uirich, 1894, consists of nine small slabs or chips of slightly calcareous clay shale and one box containing a single right valve mounted on a piece of cardboard. The slabs are in a cardboard tray that has two labels. One of these 
is a USNM label with the number 41,500 and a green diamond and a printed identification, "E. O. Ulrich Coll."; this label reads "Cotypes Ceratopsis intermedia Ulrich, Mohawkian (Trenton), Bank Lick Creek near Covington, Ky." in a handwriting that is either Ulrich's or Bassler's, and opposite the printed line "identified by" are the initials E.O.U. The other label is a small piece of paper that reads "Types, Ceratopsis intermedia Ulrich, Trenton gr. - Bank Lick creek near Covington, Ky." and is apparently in the same handwriting. Two of the slabs are numbered 41,499 in India ink and 81 in red ink; these are somewhat thicker than the other slabs, do not have many well-preserved ostracode specimens, and perhaps should not be considered part of the type lot. One slab is unnumbered; the other slabs are all numbered 41,500 in India ink, but three of them are numbered 80 in red ink, and two are numbered 78 in red ink. Seven specimens have been removed by Berdan from the largest slab numbered 78 , and one specimen has been removed from the smallest slab numbered 80 , for photographic purposes (pl. 5, figs. 6-11); these specimens are now mounted on slides. In addition, 30 specimens on the largest slab numbered 80 have been numbered and circled in India ink. Twenty-six of these specimens have been measured as shown on fig. 16. Specimens of Ceratopsis are abundant and oriented at random on the slabs numbered 78 and 80 ; they are associated with fragments of brachiopods and trilobites.

The box contains a piece of cardboard with one right valve mounted on a green background superimposed on a black background. Written on the cardboard is the following: "41,500, Ceratopsis intermedia Ulrich, Trenton gr., Bank Lick Creek near Covington, Ky.," in the same handwriting as is on the labels in the tray. This single specimen may have been selected by Ulrich as the type, but there is no indication in the labeling that it has any more taxonomic standing than do the specimens on the slabs, and it is here considered a paralectotype. Only one heteromorphic specimen was found in the type lot; this is on the smallest slab labeled 78 in red; unfortunately, it shows only the interior of the valve, the exterior being embedded in matrix. Because of this, it has not been chosen as the lectotype, although the heteromorphic velum is well displayed (pl. 5, fig. 12).

On contemporary maps (Luft, 1971), the name of Banklick Creek is spelled as one word, rather than two as on Ulrich's labels. This creek flows through the southern parts of the Covington and Newport $71 / 2$-minute Quadrangles, Ky., and joins the Licking River just south of Covington. The Point Pleasant Tongue of the Clays Ferry Formation crops out on Banklick Creek and in tributary gullies for about half a mile upstream from the mouth of the creek (Luft, 1971; Gibbons, 1973); it presumably represents the beds that
Ulrich called the Trenton Group, the source of the types of $C$. intermedia. Swadley, Luft, and Gibbons (1975, $p$. A30) have correlated the Point Pleasant Tongue with the upper part of the Lexington Limestone of central Kentucky.

Ceratopsis intermedia differs from both $C$. robusta and $C$. chambersi in having a palmate rather than spinelike speral process, deeper and wider sulci, and more emaciated lobes. It is much closer to $C$. oculifera, which also has emaciated lobes and a palmate speral process. However, although the fimbria of $C$. oculifera does not completely encircle the speral process as shown by Hall (1871, pl. 8 , fig. 9), the ventral edge curves anteriorly and the anterior face of the speral process is subcircular, whereas in $C$. intermedia, the fimbria is reflected posteriorly and the speral process is more elongate (pl. 5, figs. 1, 6). Furthermore, L2 of $C$. oculifera is less well developed and closer to the speral process than is that of $C$. intermedia. As $C$. intermedia is characteristic of the Lexington Limestone and equivalent formations and as $C$. oculifera occurs in the top of the Fairview or base of the Bull Fork, the two species are here considered distinct.

The speral process of $C$. quadrifida is broken (Jones, 1891, fig. 9a) so that it is difficult to compare this species with other species of Ceratopsis. However, L2 of $C$. quadrifida, which is also broken at its dorsal end, appears to have been larger and to have had a more distinct dorsal knob than that of $C$. intermedia or any of the other described species of Ceratopsis (pl. 5, fig. 19). The carinate ventral lobe of both $C$. duftonensis and $C$. brittanica distinguishes them from $C$. intermedia. The differences between $C$. intermedia, $C$. fimbriata n. sp., and $C$. asymmetrica $\mathrm{n}$. sp. will be discussed under the latter two species.

Types.-Lectotype, a tecnomorphic right valve, USNM 41500A; paralectotypes, USNM 41500B-G; measured paralectotypes on slab, USNM 41500, specimens 1-4, 6-9, 11-15, 17, 18, 23, 24, 26, 28, 29; figured hypotypes, USNM 239991, 239992, 239994, 271029-271031, 271036; measured hypotypes, USNM 239993 (22 specimens on one slide).

Occurrence. -Ceratopsis intermedia occurs in both the Lexington Limestone (Grier, Perryville, Tanglewood, and Millersburg) and the Clays Ferry Formation and ranges in age from Kirkfieldian to early Edenian. A total of 1,463 more or less complete specimens, along with a plethora of fragments, was recovered from the following 10 localities and 21 USGS collections: Hunters Ferry Road, 4191-CO (56); Antioch Church Road, 4876-CO (3), 4879-CO (863), 4880-CO (65), D1629-CO (359); Perryville South, 5015-CO (too fragmental for accurate count); Frankfort East, 5089-CO (15); Devils Hollow Road, 5093-CO (6); Daniel Boone Y.M.C.A. 
Camp, 5096-CO (4); Ford-Boonesboro Road, 6945-CO (too fragmental for accurate count); Dry Fork Road, 7039-CO (2), 7079-CO (1); Sadieville C, 7454-CO (33), 7455-CO (13), 7456-CO (22), 7458-CO (1), 7459-CO (10), 7462-CO (2), 7467-CO (2); Gratz A, D1301-CO (1), D1309-CO (5). As noted above, Ulrich's original type collection apparently came from beds now considered the Point Pleasant Tongue of the Clays Ferry Formation.

In addition to its occurrence in the Lexington and the Clays Ferry, C. intermedia is also known from the lower part of the Upper Ordovician (Edenian) Kope Formation of the Cincinnati area (Warshauer, 1975).

\section{Ceratopsis asymmetrica $n$. sp.}

Plate 6, figures $1-3,5,6$; plate 7 , figures $10-12$; plate 8 , fig. 8 .

Diagnosis.-Ceratopsis with subtriangular speral process obliquely oriented to lateral surface of valve; fimbria extends to base of process. Subvelar area shallow and wider on right valve than left.

Description. - Lateral outline subelliptical, slightly preplete. Valves equal in size, although left valves seem to be more variable than right valves. Greatest length slightly dorsal of midheight; greatest height slightly anterior of midlength. Greatest width, exclusive of speral process, coincident with central part of histium. Hingeline straight and approximately 80 percent of greatest length. Ventral margin strongly convex and grades into convex anterior and posterior margins. Anterior more bluntly rounded than posterior. Cardinal angles obtuse and subequal. Velar frill well developed and present on anterior and ventral parts of valve but lacking on posterior. Velar frill and poorly defined marginal rim are subparallel around most of free margin but coalesce at anterodorsal cardinal angle and approximately at midheight of posterior margin. In lateral view, marginal rim is concealed by velar frill around anterior, ventral, and posteroventral parts of free margin, but not posterodorsally. Subvelar field consists of flattened areas that slope inward from distal edge of velar rim to marginal rim and are not impressed to form a canaliculus as in other species of the genus. Subvelar area of right valve is considerably wider than that of left valve. Because of widening of right infravelar area, distal margin of velar frill flares outward midventrally.

L1 prominent, modified into flattened subtriangular speral process, which is obliquely oriented to lateral surface of valve. Process rimmed by fimbria that extends to base. Distally, speral process pointed and directed posterodorsally. L2 short, inclined posteriorly and does not reach dorsal margin. Dorsal part of $\mathrm{L} 2$ is subhemispherical node, which is separated from wide ventral part by poorly defined sag in lobe. L2 separated from L1 by narrow, deeply incised S1 and from L3 by wide deep S2. L3 long, narrow, concave anteriorly, and extends slightly above dorsal margin. S3 wide, flares dorsally. L4 wide, not well defined, grades into posterior and posterodorsal margins. All lobes connected ventrally by lateral connecting lobe, which is rounded ventrally and represents subdued histial structure. Histial connecting lobe parallel to velar frill, merges into lateral valve surface posteroventrally. No hingement or sexual dimorphism observed.

Measurements. - Measurements of the holotype and 82 paratypes are given in table 16. A statistical summary of the measurements is given in table 17.

TABLE 16. - Measurements (in $\mathrm{mm}$ ) of 83 specimens of Ceratopsis asymmetrica from the Grier Limestone Member of the Lexington Limestone

[Specimen 1, USNM 239988, USGS colln. No. 4879-CO; specimens 2-83, USNM 239990, USGS colln. No. 4191-CO]

\begin{tabular}{|c|c|c|c|}
\hline & Valve & Length & Height \\
\hline \multicolumn{4}{|c|}{ Holotype } \\
\hline 1 & Left _----------- & 1.683 & 0.986 \\
\hline \multicolumn{4}{|c|}{ Paratypes } \\
\hline $\begin{array}{l}2 \\
3 \\
4 \\
5 \\
6 \\
7\end{array}$ & 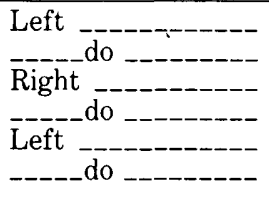 & $\begin{array}{l}1.140 \\
1.680 \\
1.320 \\
1.480 \\
1.680 \\
1.440\end{array}$ & $\begin{array}{r}0.680 \\
.980 \\
.780 \\
.900 \\
1.000 \\
.820\end{array}$ \\
\hline $\begin{array}{r}8 \\
9 \\
10 \\
11 \\
12 \\
13\end{array}$ & 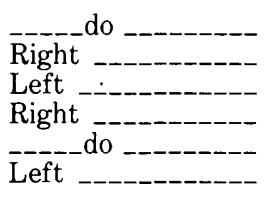 & $\begin{array}{l}1.140 \\
1.420 \\
1.322 \\
1.780 \\
1.340 \\
1.540\end{array}$ & $\begin{array}{r}.700 \\
.820 \\
.780 \\
1.000 \\
.780 \\
.900\end{array}$ \\
\hline $\begin{array}{l}14 \\
15 \\
16 \\
17 \\
18 \\
19\end{array}$ & 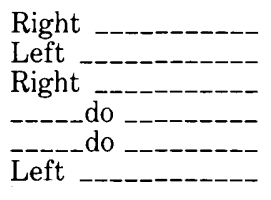 & $\begin{array}{l}1.380 \\
1.682 \\
1.380 \\
1.440 \\
1.760 \\
1.600\end{array}$ & $\begin{array}{l}.840 \\
.980 \\
.780 \\
.840 \\
.960 \\
.940\end{array}$ \\
\hline $\begin{array}{l}20 \\
21 \\
22 \\
23 \\
24 \\
25\end{array}$ & 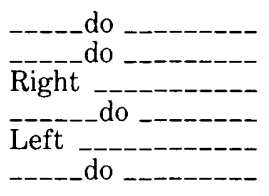 & $\begin{array}{l}1.580 \\
1.260 \\
1.280 \\
1.060 \\
1.020 \\
1.100\end{array}$ & $\begin{array}{l}.940 \\
.760 \\
.760 \\
.600 \\
.620 \\
.620\end{array}$ \\
\hline $\begin{array}{l}26 \\
27 \\
28 \\
29 \\
30 \\
31\end{array}$ & 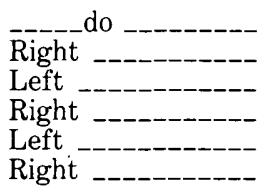 & $\begin{array}{l}1.020 \\
1.500 \\
1.542 \\
1.260 \\
1.220 \\
1.560\end{array}$ & $\begin{array}{l}.600 \\
.840 \\
.900 \\
.720 \\
.720 \\
.940\end{array}$ \\
\hline $\begin{array}{l}32 \\
33 \\
34 \\
35 \\
36 \\
37\end{array}$ & 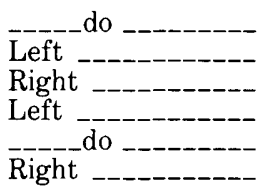 & $\begin{array}{l}1.060 \\
1.102 \\
1.440 \\
1.602 \\
1.300 \\
1.640\end{array}$ & $\begin{array}{l}.620 \\
.620 \\
.980 \\
.940 \\
.800 \\
.940\end{array}$ \\
\hline $\begin{array}{l}38 \\
39 \\
40\end{array}$ & 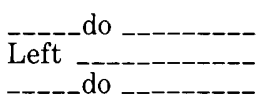 & $\begin{array}{r}1.342 \\
1.362 \\
.880\end{array}$ & $\begin{array}{l}.800 \\
.820 \\
.520\end{array}$ \\
\hline
\end{tabular}


TABLE 16. - Measurements (in $\mathrm{mm}$ ) of 83 specimens of Ceratopsis asymmetrica from the Grier Limestone Member of the Lexington Limestone-Continued

\begin{tabular}{|c|c|c|c|}
\hline & Valve & Length & Height \\
\hline \multicolumn{4}{|c|}{ Paratypes-Continued } \\
\hline $\begin{array}{l}41 \\
42 \\
43\end{array}$ & 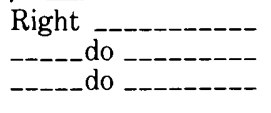 & $\begin{array}{r}1.282 \\
1.160 \\
.820\end{array}$ & $\begin{array}{l}.760 \\
.700 \\
.480\end{array}$ \\
\hline $\begin{array}{l}44 \\
45 \\
46 \\
47 \\
48 \\
49\end{array}$ & $\begin{array}{l}\text { Left } \\
\text { Right } \\
\text { Left -- } \\
\text { Right } \\
\text { Left }\end{array}$ & $\begin{array}{r}1.200 \\
1.280 \\
1.320 \\
1.580 \\
1.420 \\
.980\end{array}$ & $\begin{array}{l}.720 \\
.780 \\
.760 \\
.860 \\
.860 \\
.580\end{array}$ \\
\hline $\begin{array}{l}50 \\
51 \\
52 \\
53 \\
54 \\
55\end{array}$ & 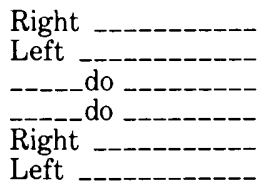 & $\begin{array}{l}1.260 \\
1.120 \\
1.420 \\
1.400 \\
1.142 \\
1.200\end{array}$ & $\begin{array}{l}.780 \\
.700 \\
.880 \\
.860 \\
.700 \\
.700\end{array}$ \\
\hline $\begin{array}{l}56 \\
57 \\
58 \\
59 \\
60 \\
61\end{array}$ & 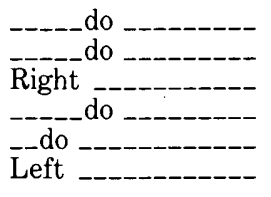 & $\begin{array}{l}1.460 \\
1.442 \\
1.022 \\
1.360 \\
1.140 \\
1.360\end{array}$ & $\begin{array}{l}.880 \\
.860 \\
.620 \\
.800 \\
.640 \\
.760\end{array}$ \\
\hline $\begin{array}{l}62 \\
63 \\
64 \\
65 \\
66 \\
67\end{array}$ & 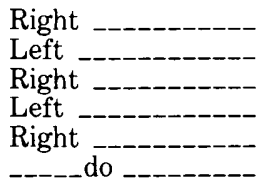 & $\begin{array}{l}1.600 \\
1.480 \\
1.200 \\
1.680 \\
1.240 \\
1.320\end{array}$ & $\begin{array}{l}.942 \\
.840 \\
.760 \\
.982 \\
.820 \\
.800\end{array}$ \\
\hline $\begin{array}{l}68 \\
69 \\
70 \\
71 \\
72 \\
73\end{array}$ & 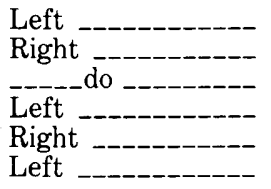 & $\begin{array}{r}1.440 \\
1.160 \\
1.220 \\
.940 \\
1.020 \\
1.382\end{array}$ & $\begin{array}{l}.842 \\
.680 \\
.700 \\
.540 \\
.580 \\
.820\end{array}$ \\
\hline $\begin{array}{l}74 \\
75 \\
76 \\
77 \\
78 \\
79\end{array}$ & 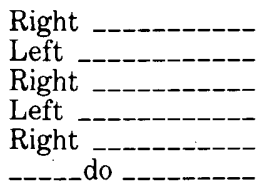 & $\begin{array}{r}1.180 \\
1.280 \\
.982 \\
.980 \\
1.340 \\
1.060\end{array}$ & $\begin{array}{l}.720 \\
.762 \\
.620 \\
.620 \\
.820 \\
.640\end{array}$ \\
\hline $\begin{array}{l}80 \\
81 \\
82 \\
83\end{array}$ & 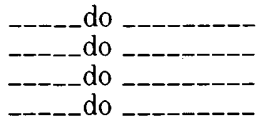 & $\begin{array}{l}1.040 \\
1.260 \\
1.282 \\
1.000\end{array}$ & $\begin{array}{l}.620 \\
.740 \\
.740 \\
.620\end{array}$ \\
\hline
\end{tabular}

Ontogeny. - The size-dispersion diagram (fig. 18) shows the existence of seven growth stages, the adult through the adult-6 (A-6). Discrimination of the instar clusters was greatly enhanced by the separate plotting of right and left valves, the right valves providing the better defined ontogenetic series. Morphologic changes during ontogeny, with the exception of the expected changes in absolute size, are restricted to changes in shape of the lateral valve outline, the velar frill, and the speral process. In the smallest instar, A-6, the valve is strongly preplete but nevertheless has the four lobes of
TABLE 17.-Statistical summary of measurements (in $\mathrm{mm}$ ) for Ceratopsis asymmetrica

\begin{tabular}{|c|c|c|c|c|c|c|c|}
\hline \multirow{2}{*}{ Instar } & \multirow{2}{*}{$\begin{array}{c}\text { No. of } \\
\text { specimens }\end{array}$} & \multicolumn{3}{|c|}{ Length } & \multicolumn{3}{|c|}{ Height } \\
\hline & & Mean & Minimum & Maximum & Mean & Minimum & Maximum \\
\hline Adult & 6 & 1.710 & 1.680 & 1.780 & 0.984 & 0.960 & 1.000 \\
\hline A-1 & 9 & 1.580 & 1.540 & 1.640 & .922 & .860 & .940 \\
\hline A-2 & 16 & 1.430 & 1.380 & 1.520 & .854 & .820 & .980 \\
\hline A-3 & 20 & 1.310 & 1.260 & 1.361 & .775 & .720 & .820 \\
\hline$A-4$ & 13 & 1.180 & 1.140 & 1.240 & .710 & .640 & .820 \\
\hline$A-5$ & 15 & 1.038 & .980 & 1.120 & .619 & .580 & .780 \\
\hline$A-6$ & 3 & .880 & .820 & .940 & .510 & .480 & .540 \\
\hline
\end{tabular}

the adult. L3, however, does not extend above the hinge line. The speral process is relatively thinner and narrower, looking like that of the adults of Ceratopsis chambersi. In addition, although the velar frill is present, it is not as relatively wide as in the adult. Morphologic characters of the A-5, A-4 (USNM 271032, pl. 7, fig. 10), and A-3 instars are intermediate between those of the A-6 instar and the adult and reflect a steady ontogenetic change; the outline of the valves changes from strongly preplete to nearly subquadrate, the speral process changes from long and narrow to short and subtriangular, the dorsal part of L3 extends above the hingeline, and the velar frill becomes relatively wider. Essentially adult morphology is present in the adult- 1 .

Growth is curvilinear, height $=0.596$, length $=0.974$, and the data points correlate closely to the equation, $r=0.987$.

Discussion.-Ceratopsis asymmetrica closely resembles $C$. intermedia, with which it is associated in most collections, but differs mainly in the asymmetrical development of the subvelar field. A difference also exists in the form of the speral process, the process of $C$. asymmetrica being subtriangular and inclined obliquely to the lateral surface of the valve. In C. intermedia, on the other hand, the process is palmate and faces anteriorly. However, such a wide range in variation exists in both the shape and the orientation of the speral process of both species that it is sometimes difficult to differentiate the taxa on the basis of this character alone. The shape of the subvelar field, on the other hand, seems to be invariate as a specific character. The species are so similar that initially we thought that perhaps $C$. intermedia and $C$. asymmetrica were dimorphs of one another, $C$. intermedia being the heteromorph and the infravelar antrum being a dimorphic character. However, when we plotted the height and length of the two species (separated on the basis of subvelar field morphology) from the same collection (fig. 19), we could see that they had distinct juvenile stages. Subsequently, true heteromorphs of $C$. intermedia were discovered, with velar dimorphism as described by Warshauer (1975) for C. chambersi.

The subhemispherical dorsal node of L2 of C. asymmetrica is commonly broken. This node may represent 


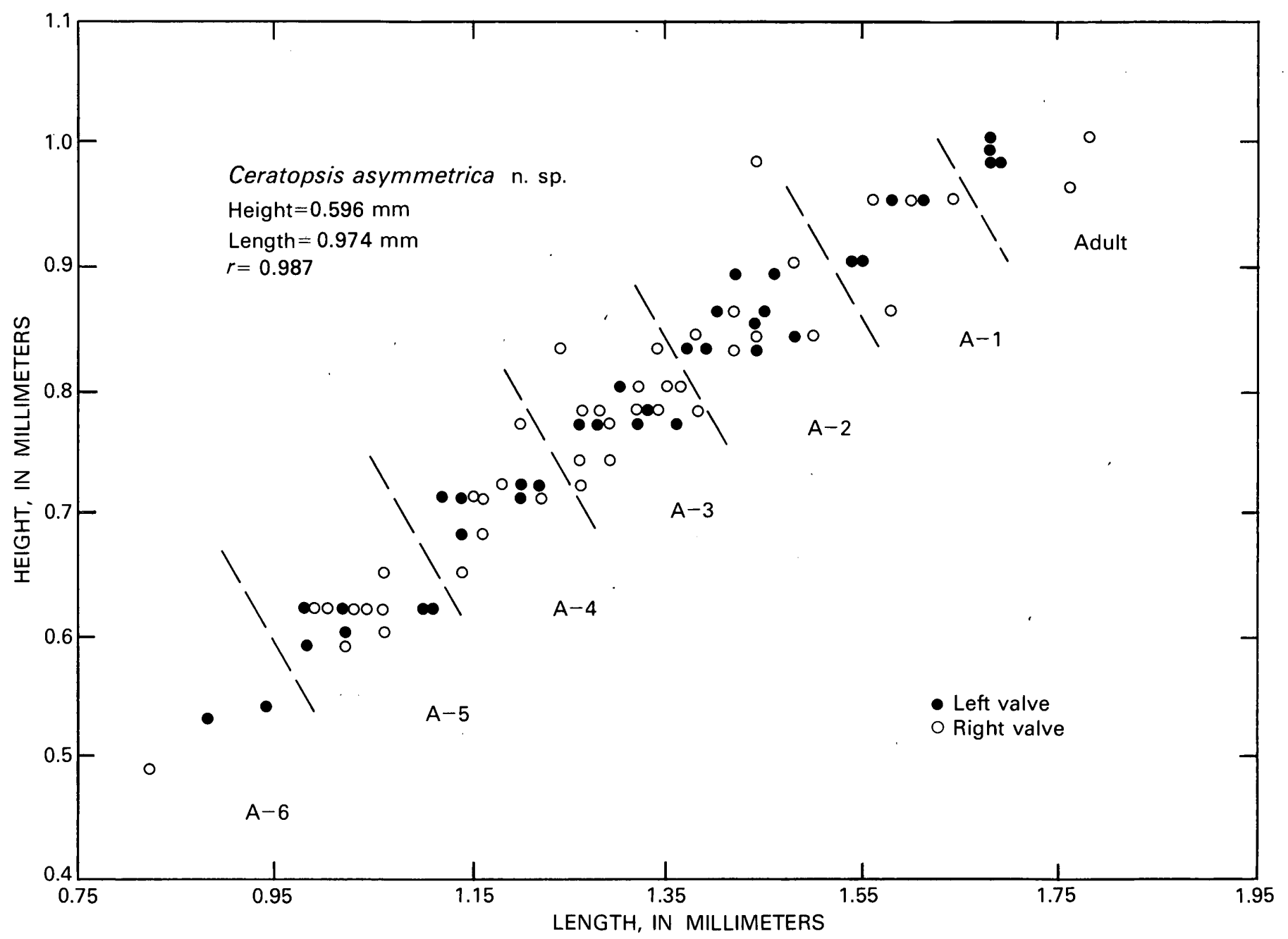

Figure 18. - Size-dispersion diagram for 82 specimens of Ceratopsis asymmetrica from the Grier Limestone Member of the Lexington Limestone at Hunters Ferry Road (Valley View B). Specimens are from USGS 4191-CO; USNM 23999.

an eye spot, breakage being due thin, light-transmitting calcite.

The specific name asymmetrica refers to the unequal nature of the infravelar area on the opposite valves of a single carapace (pl. 6, fig. 1, 5).

Types. - Holotype, a silicified tecnomorphic left valve, USNM 239988, from the Lexington Limestone, Millersburg Member, Valley View C (Antioch Church Road), 38-41 ft above base of section, USGS colln. 4879-CO. Figured paratypes, USNM 239989, 271032-271034; unfigured paratypes, USNM 239990 (82 specimens on two slides).

Occurrence.-Ceratopsis asymmetrica occurs in both the Lexington Limestone (Curdsville, Logana, Grier, Tanglewood, Perryville, and Millersburg) and the Clays Ferry Formation, including the Point Pleasant Tongue; it ranges in age from Kirkfieldian to early Edenian. A total of 3,662 specimens, plus numerous fragments, were collected from the following 14 USGS localities and 28 collections: Hunters Ferry Road, 4191-CO (209); Antioch Church Road, 4876-CO (3), 4879-CO (2734), 4880-CO (73), D1629-CO (359); Perryville South, 5015-CO (present, but too fragmental to count); Tyrone C, 5086-CO (36); Frankfort East A, 5089-CO (16), D1196-CO (11); Devils Hollow Road, 5093-CO (10); Daniel Boone Y.M.C.A. Camp, 5096-CO (8); Hickman Creek, 5101-CO (1); Ford-Boonesboro Road, 6945-CO (too fragmental for accurate count); Dry Fork Road, 7039-CO (4), 7041-CO (too fragmental for accurate count), 7043-CO (too fragmental for accurate count), 7071-CO (6); Sadieville C, 7454-CO (59), 7455-CO (35), 7456-CO (36), 7458-CO (6), 7459-CO (12), 7461-CO (24), 7467-CO (2); Switzer A, D1106-CO (7); Clays Ferry type section, D1169-CO (3), D1170-CO (4); Gratz A, D1312-CO (4).

As presently understood, $C$. asymmetrica does not occur in any rocks other than those reported here. 


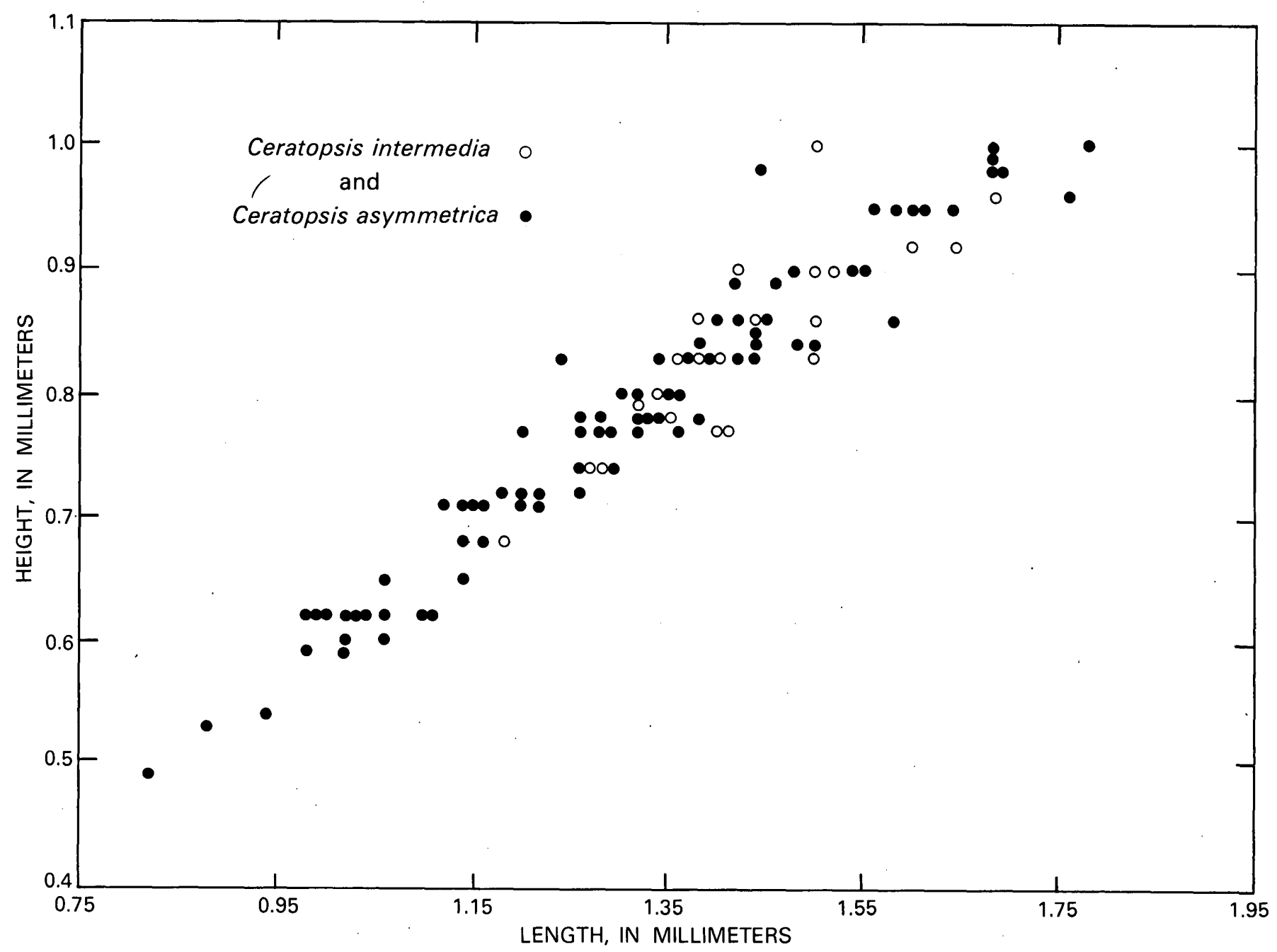

FIGURE 19. - Joint size-dispersion diagram for the specimens of Ceratopsis intermedia and C. asymmetrica plotted in figures 17 and 18 . USGS colln. No. 4191-CO.

Ceratopsis fimbriata n. sp.

Plate 7, figures $13-15$

Diagnosis.-Ceratopsis with elongate, subtriangular speral process that is prolonged ventrally and reflexed to join with connecting lobe. Process does not extend far above dorsal margin, and its distal edge is fimbriate along entire length. Velar frill of both tecnomorphs and heteromorphs extends to posterodorsal cardinal angle as velar ridge.

Description.-Valves subelliptical in lateral view, slightly preplete. Greatest length slightly dorsal of midheight, greatest height slightly anterior of midlength. Greatest width, exclusive of speral process, coincident with central part of histial connecting lobe. Hingeline straight and approximately 82 percent of greatest length. Ventral margin convex and grades into convex anterior and posterior margins. Anterior margin more convex than posterior. Cardinal angles obtuse and subequal. Velar frill of tecnomorph well developed, concave away from free margin, and extends completely around free margin but as sharp velar bend posterodorsally, better defined anteriorly and ventrally. Velar structure and subdued marginal rim subparallel and distinct around entire free margin. Marginal rim poorly developed on posterodorsal margin, concealed in lateral view by velar frill on anterior and ventral margins. Subvelar field poorly known.

L1 prominent, modified into elongate, subtriangular speral process extending to histial connecting lobe and curved posteriorly; dorsal end pointed, directed posterodorsally, does not extend far above hingeline. Well-developed fimbria along entire distal edge of speral process. L2 short, inclined posterodorsally, does not extend to dorsal margin. L2 divided into two unequal parts; dorsal part small, subhemispherical, separated from ventral part by weak sag; ventral part elongate, 
inflated, and separated from histial connecting lobe by narrow sag. L2 separated from L1 by relatively narrow, deeply incised S1; from L3, by wide, deep, subtriangular S2. L3 long, narrow, extends to dorsal margin in tecnomorphs and slightly above dorsal margin in heteromorph, curved, with concave side facing anteriorly. S3 wide, subtriangular, flaring dorsally. L4 wide, not as well defined as other lobes, grades into posterodorsal margin. All lobes connected ventrally by histial connecting lobe, which is parallel to velar ridge and merges into lateral valve surface posteroventrally. Ventral part of connecting lobe subrounded and sags ventrally; lobe becomes extremely narrow just anterior of junction with L2. Hingement not observed.

Velar frill of heteromorph wider than tecnomorphic frill and curved in toward free margin; anterior part of frill finely reticulate, ventral and posteroventral parts radially striate.

Measurements. - The holotype, a heteromorphic right valve, is $1.776 \mathrm{~mm}$ long and $1.008 \mathrm{~mm}$ high, exclusive of the speral process. A paratype tecnomorphic left valve is $1.488 \mathrm{~mm}$ long and $0.864 \mathrm{~mm}$ high. Another paratype, an immature left valve, is $0.936 \mathrm{~mm}$ long and $0.528 \mathrm{~mm}$ high. Other specimens were too fragmentary to measure.

Discussion. - The holotype and both paratypes are pyritized, and the approximately 15 other more or less complete specimens on which the description is based are either pyritized or coarsely recrystallized. The pyritized specimens are fragile, and on some specimens the outermost surface of the valve may not be preserved. The reticulate surface of the anterior part of the velum of the holotype is believed to represent the original outer surface, but the radially striate part of the velum may be a subinternal mold. Too few complete valves are available to study the ontogeny of this species in detail. However, the few juveniles that can be recognized, the most complete being USNM 240003 (pl. 7 , fig. 14), show a trend common to the ontogeny of other species of the genus; the speral process of the juveniles is relatively longer and projects higher above the hingeline than it does in the adult. The largest tecnomorph (USNM 240001, pl. 7, fig. 13) differs from the adult heteromorph in that L3 does not extend above the hingeline in lateral view. However, we do not know whether this is a dimorphic difference or whether it is ontogenetic, as this specimen may represent the A-1 instar rather than the adult.

Ceratopsis fimbriata differs from other species of the genus in the development of the velar structure, which extends around the entire free market rather than ending below the posterodorsal cardinal angle as in the other species. In addition, the long recurved speral process of C. fimbriata is unlike those of other species.
Ceratopsis duftonensis (Reed, 1910), as illustrated by Siveter (1978, pl. 3, figs. 1, 2), resembles C. fimbriata in having the fimbria extending down the shaft of the speral process but the speral process of $C$. duftonensis is palmate rather than lanceolate as in C. fimbriata. The specific name fimbriata refers to the well-developed fimbria (fringe) on the speral process.

Types. - Holotype, a heteromorphic right valve, USNM 240002 (pl. 7, fig. 15) from the Millersburg Member of the Lexington Limestone, Dry Fork Road section, USGS colln. 7079-CO. Figured paratypes, USNM 240001 and 240003, both from the Clays Ferry Formation, Ford-Boonesboro Road section, USGS colln. 6945-CO.

Occurrence.-Eighteen more or less complete specimens and numerous fragments were collected from the Millersburg Member of the Lexington Limestone and from the Clays Ferry Formation, from the following three localities and nine USGS collections, all of Edenian Age: Ford-Boonesboro Road, 6945-CO (2 and many fragments); Dry Fork Road, 7039-CO (5), 7041-CO (3-5), 7043-CO (too fragmental for accurate count), 7054-CO (1), 7059-CO (1), 7079-CO (1 and fragments); Sadieville C, 7454-CO (1), 7455-CO (5). This species is not yet known to occur anywhere else.

\section{Ceratopsis chambersi (Miller, 1874) \\ Plate 7, figure 16; plate 8 , figure 5}

1874b. Beyrichia chambersi Miller, p. 234, text-fig. 27.

1875. not Beyrichia chambersi Miller. Hall and Whitfield, p. 104, pl. 4, figs. 11-12.

1890. Tetradella chambersi (Miller). Ulrich, p. 112.

1894. not Ceratopsis chambersi (Miller). Ulrich, p. 676, pl. 46, figs. 19-22.

1934. Ceratopsis chambersi (Miller). Bassler and Kellett, p. 242 (see for additional references).

1951. Ceratopsis chambersi (Miller). Keenan, p. 564, pl. 78, fig. 7.

1975. Ceratopsis chambersi (Miller). Warshauer, p. 445-452, pls. 1-3.

Discussion. -A revised systematic description and discussion has been given by Warshauer (1975) and will not be repeated here. With the exception of a slight variation in the shape of the speral process shown by some of the specimens, the material herein referred to C. chambersi agrees closely with that illustrated by Warshauer $(1975$, pls. 1-3). The variants that have a subtriangular process might possibly represent a different species; however, as all other morphologic characters resemble $C$. chambersi, these variants are felt to represent that taxon.

As most of the specimens examined during this investigation were incomplete, no biometric studies were attempted. A nearly complete adult tecnomorph (USNM 240004; pl. 7, fig. 16) was measured: length, $1.58 \mathrm{~mm}$; height, $1.01 \mathrm{~mm}$; length of hingeline, $1.32 \mathrm{~mm}$. 
Types. - Figured hypotypes, USNM 240004, 240005.

Occurrence.-Specimens of $C$. chambersi were found only in the Clays Ferry Formation at one stratigraphic section, Sadieville C. At this locality, 162 specimens were recovered from five USGS collections, all of Edenian Age: 7471-CO (18), 7472-CO (19), 7475-CO (2, spines only), $7477-\mathrm{CO}$ (65 valve fragments and spines), $7478-\mathrm{CO}(58)$.

\section{Ceratopsis? sp.}

Plate 8 , figures $1-4$

Discussion. - Four incomplete specimens of a quadrilobate ostracode generally resembling Ceratopsis have been found in the Clays Ferry Formation. Three of the specimens are broken anterodorsally, so it is not possible to determine whether or not a speral process was present. One specimen (USNM 240020 , pl. 8, figs. $2-4)$ has a stump that may be a process base. Although the lobation of these specimens is similar to that of Ceratopsis, they differ from other species of the genus in that the histial and velar structures, which are distinct on the posteroventral surface, merge together to form a single ridge ventrally and anteroventrally. A wide deep channel occupies the area between this ridge and the valve margin. These characters, together with the uncertainty regarding the speral process, suggest a possible relationship to northwestern European genera such as Polyceratella Öpik, 1937, and Pseudotallinnella Sarv, 1959. Pending the discovery of better preserved specimens, the generic assignment of the Kentucky material is queried.

Measurements. - One of the figured specimens, USNM 240020 , is $2.050 \mathrm{~mm}$ long and approximately (owing to breakage) $1.161 \mathrm{~mm}$ high.

Types. - Figured specimens, USNM 240020, 271035.

Occurrence. - Specimens were found in two samples from the Clays Ferry Formation (Edenian) at the Sadieville C section: USGS collns. 7472-CO (1), 7477-CO (3).

\section{Family uncertain}

Genus DICRANELLA Ulrich, 1894

Type species.-Dicranella bicornis Ulrich, 1894.

Dicranella sp.

Plate 9, figure 4

Discussion.-A broken fragment with the characteristic dorsally directed horns and velum of Dicranella Ulrich, 1894, is illustrated here to document the occurrence of this genus in the Lexington Limestone. The specimen is far too poorly preserved to assign to a species or to measure.

Types.-Figured specimen USNM 271039.
Occurrence. - The fragmentary specimen was found in the Millersburg Member of the Lexington Limestone (Edenian), Dry Fork Road section, USGS colln. 7041-CO.

\section{Dicranella? sp. aff. D.? marginata Ulrich, 1894}

Plate 9, figure 6

1894. Dicranella marginata Ulrich, p. 666 , pl. 44, figs. $27,28$. 1934. Dicranella marginata Ulrich. Bassler and Kellett, p. 286 (see for earlier references).

1940. Dicranella marginata Ulrich. Kay, p. 260-261, pl. 33, fig. 4. 1965. Dicranella marginata Ulrich. Copeland, p. 49-50, pl. 11, fig. 15.

Description. - Lateral outline preplete; dorsal margin straight, anterior margin nearly straight, curving into smoothly curved ventral margin, posterior margin straight in ventral part but abruptly curved above midheight. Anterior cardinal angle nearly $90^{\circ}$, posterior cardinal angle obtuse. L1 flattened; S1 shallow, narrow, in dorsal half of valve; L2 distinct subovate knob which does not reach dorsal margin; S2 deep, curved anteriorly, extends to midheight of valve; L3 projects laterally, does not project above dorsal margin, bounded posteriorly by hemisulcus which merges into posterior flattened part of valve. Velar ridge narrow, thick, with fine carina parallel with edge, extends to posterior quarter of valve, conceals contact margin in lateral view. Antrum narrow, widening posteriorly. Anteroventral and dorsal part of valve pustulose, remainder of valve finely granulose to smooth. Dorsal plica borders distinct narrow dorsum. Dimorphism not observed.

Measurements. - The figured specimen is $1.625 \mathrm{~mm}$ long and $1.050 \mathrm{~mm}$ high (including the velar ridge).

Discussion. - The above description is based on one well-preserved left valve, which is presumed to be a tecnomorph. It differs from forms previously assigned to Dicranella marginata Ulrich, 1894, in having L3 extended laterally rather than dorsally and set distinctly below the hingeline in lateral view; the holotype of $D$. ? marginata (USNM 41368, pl. 9, fig. 5) shows L3 protruding above the hingeline. Specimens of Dicranella? marginata of Kay (1940, pl. 33, fig. 4) and of Copeland (1965, pl. 11, fig. 15) also show L3 somewhat below the hingeline, but not as far below as the specimen from Kentucky. All specimens assigned to D.? marginata differ from Dicranella bicornis Ulrich, 1894, the type species of the genus, and other species of Dicranella such as D. macrocarinata Harris, 1931 , and $D$. fragilis Harris, 1957, in having L2 a subovate knob rather than an extended spine. This difference suggests that $D$. ? marginata may belong in some genus other than Dicranella, as proposed by Schallreuter (1966b, p. 855), and the generic assignment of this species has therefore been queried. Unfortunately, the material at hand is not 
adequate to determine the amount of variation at the generic level in Dicranella.

Types. - Figured specimen USNM 271040.

Occurrence. - One left valve and a partial external impression have been found in the lowest foot of the Curdsville Limestone Member of the Lexington Limestone, Tyrone C section, USGS colln. 5083-CO.

\section{Superfamily EURYCHILINACEA Ulrich and Bassler, 1923 Family EUR YCHILINIDAE Ulrich and Bassler, 1923}

Genus EURYCHILINA Ulrich, 1889

Type species. - Eurychilina reticulata Ulrich, 1889.

Eurychilina subradiata Ulrich, 1890

Plate 9, figures 15-17

1890. Eurychilina subradiata Ulrich, p. 126, pl. 9, figs. 1a-c, 2a-c.

1894. Eurychilina subradiata Ulrich. Ulrich, p. 661-662, pl. 44, figs. $3,4,4 \mathrm{a}$.

1908. Eurychilina subradiata Ulrich. Ulrich and Bassler, p. 299, fig. 49.

1912. Eurychilina subradiata Ulrich. Ruedemann, pl. 9, fig. 16.

1915. Eurychilina subradiata Ulrich. Bassler, p. 517.

1926. Eurychilina subradiata Ulrich. Butts, p. 124, pl. 30 , fig. 5.

1932. Eurychilina subradiata Ulrich. Bassler, pl. 10, fig. 14.

1934. Eurychilina subradiata Ulrich. Bassler and Kellett, p. 316.

1940. Eurychilina subradiata Ulrich. Kay, p. 250-251, pl. 31, fig. 5.

1957. Eurychilina subradiata Ulrich. Harris, p. 233-234, pl. 7, figs. $12 \mathrm{a}-\mathrm{c}, 14 \mathrm{a}-\mathrm{c}$.

1960a. Eurychilina subradiata Ulrich. Kesling, p. 356-357, pl. 4, fig. 3.

1961. Eurychilina subradiata Ulrich. Swain, Cornell, and Hansen, p. 349.

1965. Eurychilina subradiata Ulrich. Copeland, p. 13, pl. 4, figs. 6-13, pl. 10, figs. 15-17.

1971. Eurychilina subradiata Ulrich. Copeland, pl. 23, figs. 29-31.

1974. Eurychilina subradiata Ulrich. Copeland, p. 18.

1977a. Eurychilina subradiata Ulrich. Copeland, p. 80-81, pl. 2, figs. 4,9 , pl. 3, fig. 6 .

Discussion.-Only one broken right valve of this species has been found in our collections from Kentucky; however it shows the characteristic angulated velum, zygal arch, and cristate dorsum of Eurychilina subradiata Ulrich, 1890, although it seems to be more coarsely punctate than the syntypes (USNM 41613; 41614, pl. 9, fig. 17; topotype, USNM 41614a, pl. 9, fig. $16)$. As suggested by the lengthy synonymy, $E$. subradiata has been reported from New York to Minnesota and Oklahoma, and from the District of Franklin in the Northest Territories of Canada to Alabama. This geographically widespread taxon may include more than one species; Copeland $(1974$, p. 18$)$ has recognized a related form, Eurychilina prairiensis Copeland, 1974, which also has an angulated velum, but examination of all specimens identified as E. subradiata is beyond the scope of this paper. Measurements are not given for the specimen from the Lexington Limestone because it is incomplete at the posterior end.

\section{Types. - Hypotype, USNM 271041.}

Occurrence.-The single specimen of $E$. subradiata from the Lexington Limestone is from the lowest foot of the Curdsville Limestone Member (Kirkfieldian), Tyrone C section, USGS colln. 5083-CO.

\section{Family CHILOBOLBINIDAE Jaanusson, 1957}

Genus CYSTOMATOCHILINA Jaanusson, 1957

Type species. -Primitia (Ulrichia?) umbonata Krause, 1892.

Cystomatochilina reticulotiara n. sp.

Plate 9, figures 10-14, 18; plate 16, figure 9

Diagnosis.-Small Cystomatochilina with short subcentral S2 ending ventrally in poorly defined smooth muscle spot, L2 low, subhemispherical. Surface coarsely reticulate; L2 covered with wide pits. Anterodorsal part of valve slightly inflated.

Description.-Domicilium amplete, semicircular in lateral outline. Greatest height at midlength, greatest length just dorsal of midheight, and greatest width through apex of L2. Dorsal margin straight, ventral margin broadly curved and grades into more sharply curved, subequal, anterior and posterior margins. Cardinal angles of domicilium not well defined, but apparently obtuse and subequal. S2 short, extending 25 percent of distance to ventral border, shallow, fairly wide and subcentrally located, ending in smooth, poorly defined muscle spot. L2 (preadductorial node) anteroventral of S2. Posterior half of domicilium more inflated than anterior, anterodorsal area of domicilum also inflated.

Lateral surface of valve reticulate, except for L2 (preadductorial node), which has wide well-defined pits. Other similar pits scattered on valve surface. Velum wide, concave, extends around entire free margin to both cardinal angles, where it is narrower. Surface of velum radially striate, striations less prominent near cardinal angles. Radial striations crossed by fine subparallel concentric striations which also extend to cardinal angles. Small nodes present at junction of domicilium and velum along ventral and posteroventral borders of domicilium, lacking along anterodorsal and posterodorsal borders. Nodes approximately aligned with ridges between radial striations.

Heteromorph, subvelar field and hingement not yet known.

Measurements. - The holotype (USNM 240027) is $0.590 \mathrm{~mm}$ long and $0.410 \mathrm{~mm}$ high. The other specimens were too incomplete to measure accurately.

Discussion.-Cystomatochilina reticulotiara most closely resembles C. matura Schallreuter, 1965, which also has a reticulate surface ornament, but differs in having a less distinct preadductorial node and less acute 
cardinal angles (Schallreuter, 1965, pl. 9, figs. 2, 3). It differs from other species of Cystomatochilina such as C. umbonata (Krause, 1892), C. tiara (Henningsmoen, 1954), C. tiara densistriata (Henningsmoen, 1954), and C. permira Abushik, 1960, in its reticulate rather than pustulose ornamentation.

Jaanusson $(1957$, p. 254, 255) noted that the type species of Cystomatochilina, C. umbonata (Krause, 1892), has an indistinct adductorial pit illustrated by Triebel (1941, pl. 4, fig. 42), which is better developed in C. tiara (see Henningsmoen, 1954, pl. 4, figs. 4-9). Schallreuter (1975, p. 153) discussed the absence of a pit in his species C. matura but implied that the lack of this character was not of generic importance and considered C. permira Abushik, 1960, as a morphologic link between the species that have a well-developed adductorial node and those having a less distinct node but a more distinct sulcus. To date, $C$. reticulotiara is the only reported species of the Baltoscandian genus Cystomatochilina from North America.

The radial striations on the velum mark the position of internal partitions (pl. 9, fig. 14). The curious nodes on the ventral part of the domicilium may have served in some capacity to strengthen the valve at the junction of the domicilium and the velum. A wide velum, such as that of $C$. reticulotiara, may have induced much stress along this junction, causing it to be a zone of weakness. The added calcite of the nodes may have functioned as either a strengthening buttress or some sort of tensionreduction device. Likewise, the reticulation, especially in the inflated posterior part of the domicilium, has the appearance of a geodesic dome, a type of structure known for its light weight and extreme strength. For further discussions of structural adaptions in ostracode shells, see the informative papers of Benson (1970, 1975).

This species is exceedingly rare: only four tecnomorphic valves were found, two of which are either partly or completely exfoliated. All the specimens are small and embedded in limestone. The specific name refers to the well-developed reticulation found on the valve surface and to the tiaralike nature of the velum.

Types.-Holotype, USNM 240027, from the Strodes Creek Member of the Lexington Limestone, $10 \mathrm{ft}$ above the base of Winchester B section, USGS colln. 7318-CO. Paratypes, USNM 240028, 240029, 240030.

Occurrence. - C. reticulotiara has been found only in the Strodes Creek Member (Edenian) of the Lexington Limestone, at the following three localities and three USGS collections: Kentucky Route 89, 7312-CO (2); Winchester Reference Section B, 7318-CO (1); U.S. Route 227, 7325-CO (1).
Genus PLATYBolbiNa Henningsmoen, 1953

Subgenus RIMABOLBINA Schallreuter, 1969

Type species. - Platybolbina (Rimabolbina) rima Schallreuter, 1964.

Platybolbina (Rimabolbina) nitida (Ulrich, 1890)

Plate 9 , figures 7,8

1890. Primitia nitida Ulrich, p. 135, pl. 8, fig. 7 .

1895. not Primitia nitida (Roemer). Jones, p. 62, pl. 7, figs. 1, 2.

1915. Primitia nitida Ulrich. Bassler, p. 1032.

1934. Primitia nitida Ulrich. Bassler and Kellett, p. 451.

Diagnosis.-Platybolbina (Rimabolbina) with. dropshaped muscle spot, poorly defined sulcus extending dorsally from muscle spot, anterodorsal and posterodorsal parts of valve plicate, ornamentation finely granulose.

Description. - Lateral outline slightly preplete, dorsal margin straight to slightly sinuous, anterior and posterior margins curved, ventral margin gently curved. Anterodorsal and posterodorsal parts of valve inflated into almost cuspate plica, which is nearly obsolete middorsally. Muscle spot drop-shaped, with distinct pit, situated about two-thirds of distance below dorsal margin to ventral margin, weak sulcus extending toward but not reaching dorsal margin. Anterior and posterior cardinal angles nearly $90^{\circ}$. Surface except for muscle spot finely granulose or finely reticulate. Velum radially striate, relatively narrow and apparently complete from anterior to posterior cardinal angles, not restricted. Dimorph, subvelar field, and hingement not known.

Measurements. -The holotype is $1.15 \mathrm{~mm}$ long and $0.65 \mathrm{~mm}$ high, including the velum. The figured topotype is $1.10 \mathrm{~mm}$ long and $0.60 \mathrm{~mm}$ high, including the velum.

Discussion.-This species most closely resembles Platybolbina (Rimabolbina) chalazia (Kesling, 1960) but appears to have finer ornamentation and a more pronounced sulcus. Platybolbina (Rimabolbina) omphalota (Kesling, 1960) differs in having a more pronounced dorsal plica and coarser ornamentation. Platybolbina (Rimabolbina) rima Schallreuter, 1964, is coarsely reticulate and appears to lack a distinct dorsal plica (Schallreuter, 1964, pl. 9, fig. 1).

Kesling (1960b, p. 368-369) provided a table showing the characters of the species of Platybolbina described up to that time, from which it appears that the European species of this genus either lack or have only a weakly developed dorsal plica, whereas in most of the North American species this feature is fairly well developed. Schallreuter (1969, p. 877) based his subgenera on the character of the muscle spot, velum, 
and ornamentation and did not discuss the presence or absence of a dorsal plica and the subcuspate anterodorsal and posterodorsal areas on the North American species. The genus Apatochilina Ulrich and Bassler, 1923, appears to have the inflated subcuspate anterodorsal and posterodorsal areas, and also has a complete velum and a subcentral muscle spot. Unfortunately, the holotype (USNM 41624) of $A$. obesa (Ulrich, 1890) is not well preserved, and its surface appears to be corroded (pl. 9, fig. 9); the muscle spot is only distinct when the specimen is wetted. However, when better preserved topotype material of Apatochilina is found, some of the North American species now referred to Platybolbina probably will have to be assigned to Apatochilina.

The holotype of $P$. (R.) nitida (pl. 9, fig. 7) is calcareous and is on a chip of dark-gray limestone approximately $3 \mathrm{~cm}$ long and $1.5 \mathrm{~cm}$ wide. At least two additional specimens of $P$. (R.) nitida (pl. 9, fig. 8) and many leperditellid ostracodes are on the same chip. The label attached to the chip reads as follows: "Primitia nitida Ulrich, Trenton, up., near Paris, Ky." According to Ulrich (1890, p. 135-136) "The specimens are contained in a dark fragment of limestone which was used for ballast by the Kentucky Central Railroad. As near I can learn, the material was derived from Upper Trenton strata near Paris, Ky." Bassler (1915, p. 1032) and Bassler and Kellett.( 1934, p. 451) listed the species as from "Trenton (Perryville): Paris, Ky." If Ulrich was correct in his assumption that the railroad ballast came from the vicinity of Paris, it almost certainly represents some part of the Lexington Limestone, as no other rock suitable for ballast is exposed in that area (Outerbridge, 1974). Although we have found no other specimens of $P$. (R.) nitida in the collections from the Lexington Limestone that we have studied, the species is redescribed and refigured here to complete the Lexington ostracode fauna.

Types.-Holotype, USNM 41334; figured topotype, USNM 41334a.

Occurrence. - Probably from the Lexington Limestone near Paris, Ky.

?Family PIRETELLIDAE Öpik, 1937

Genus HESPERIDELLA Öpik, 1937

Type species. - Primitia estonica Bonnema, 1909.

Hesperidella? initialis (Ulrich, 1894)

Plate 9 , figures 1-3

1894. Beyrichia initialis Ulrich, p. 658 , pl. 43 , figs. $82,83$.

1908. Kloedenia initialis (Ulrich). Ulrich and Bassler, p. 301, pl. 38, figs. $12,13$.

1910. Kloedenia initialis (Ulrich). Grabau and Shimer, p. 355, text fig. 1663 , e, f.

1915. Kloedenia initialis (Ulrich). Bassler, p. 685.
1928. Kloedenia initialis (Ulrich). Kirk, p. 420.

1934. Kloedenia initialis (Ulrich). Bassler and Kellett, p. 362. 1940. ?Parabolbina staufferi Kay, p. 256, pl. 32, figs. 25-27.

Diagnosis.-Dorsal plica low, velum abruptly constricted posteriorly, low node at posterodorsal end of S2.

Description. - Lateral outline approximately amplete; dorsal margin straight, anterior margin rounded, ventral margin more gently curved, posterior margin irregularly curved. L1 flattened, separated from ovate, knoblike L 2 by hemisulcus S1. S2 deep, curved anteriorly, extends more than half height of domicilium. L3 inflated ventrally, broad dorsally, with low inconspicuous node near dorsal end of S2. Striated velum extends from anterior cardinal angle to posteroventral part of valve, where it is abruptly constricted. Dorsal plica most distinct on L3, less conspicuous anteriorly; anterodorsal corner of velum may protrude above dorsal margin. Shell surface granulose.

Measurements. - The holotype, USNM 41666, is 0.650 $\mathrm{mm}$ long and $0.450 \mathrm{~mm}$ high. A hypotype right valve, USNM 271038, is $0.725 \mathrm{~mm}$ long and $0.525 \mathrm{~mm}$ high. A hypotype left valve, USNM 271037 , is $0.750 \mathrm{~mm}$ long and $0.537 \mathrm{~mm}$ high.

Discussion. - Unfortunately, the holotype of Beyrichia initialis Ulrich, 1894, is poorly preserved; it is a crushed and somewhat abraded right valve compressed on the surface of a bryozoan. The velum is narrow and the specimen may be a tecnomorph, although the narrow velum may be due to poor preservation. However, we believe it to be conspecific with two heteromorphic? valves from Kentucky that have wide incurved vela, and much of the foregoing description has been based on these hypotypes. Kesling, Hall, and Melik (1962) described two species that they assigned to Hesperidella-H. michiganensis Kesling, Hall, and Melik, 1962, and Hesperidella sp. Neither these, nor Hesperidella? initialis have the distinct characteristic crista outlining the posterior side of S2 that is found in $H$. esthonica (Bonnema, 1909), the type species of Hesperidella Öpik, 1937. Jaanusson (1957, p. 327) considered the crista diagnostic of the genus, as did Kesling, Hall, and Melik (1962, p. 209), although this feature appears obsolete on the Michigan forms. Until more and better material of $H$.? initialis can be studied, it seems desirable to query the generic assignment of this species. Hesperidella? initialis differs from the species from Michigan in having the velum more sharply restricted posteriorly and in having no crista; the dorsal plica is also less well developed. Parabolbina staufferi Kay, 1940 , may be synonymous with $H$.? initialis, as both come from the Decorah Shale of Minnesota, but we have not seen the types of $P$. staufferi and Kay's figures (Kay, 1940, pl. 32, figs. 25-27), although suggestive, are not conclusive. 
Types.-Holotype, USNM 41666; figured hypotypes, USNM 271037, 271038.

Occurrence.-According to Ulrich (1894, see 1897, p. 658), Hesperidella? initialis comes from "Middle third of the Trenton shales, Minneapolis, Minnesota." The label with the holotype specifies the "Rhinidictya bed." In current stratigraphic terminology, both these statements refer to the Guttenberg Limestone Member of the Decorah Shale. The two hypotypes were found in the lowest foot of the Curdsville Limestone Member (Kirkfieldian) of the Lexington Limestone, Tyrone C section, USGS colln. 5083-CO.

\author{
Superfamily OEPIKELLACEA Jaanusson, 1957 \\ Family OEPIKELLIDAE Jaanusson, 1957 \\ Genus OEPIKELLA Thorslund, 1940
}

Type species. -Oepikella tvaerensis Thorslund, 1940.

\section{Oepikella sp.}

Plate 10, figure 6

Description.-Lateral outline subelliptical, slightly preplete; dorsal margin gently arched, anterior margin smoothly curved, rounding into gently curved ventral margin, posterior margin more sharply curved than anterior. Hingeline incised, obtuse cardinal angles somewhat flattened and set off from domicilium. Greatest length at or above midheight, greatest height through midlength, greatest width posterior to and slightly ventral of midpoint of valve. Obscure oval muscle spot in center of valve. Velar bend around free margin distinctly separated from domicilium by shallow groove. Shell surface smooth.

Measurements. -The single specimen is $1.900 \mathrm{~mm}$ long and $1.387 \mathrm{~mm}$ high.

Discussion. - This tecnomorphic right valve is most similar to Oepikella labrosa Copeland, 1965, but appears to have more distinct cardinal angles and to be relatively less elongate. However, whether or not this taxon falls within the range of variation of $O$. labrosa cannot be determined without additional material. The presence of distinct cardinal angles and absence of marginal spines indicates that this specimen belongs in Oepikella Thorslund, 1940, rather than Eoaquapulex Levinson, 1968 (described as Diplopsis Levinson, 1961).

Types. - Figured specimen USNM 271044.

Occurrence. - The single valve was found in the lowest foot of the Curdsville Limestone Member (Kirkfieldian) of the Lexington Limestone, Tyrone C section, USGS colln. 5083-CO.
Genus MACRONOTELLA Ulrich, 1894

Type species. -Macronetella scofieldi Ulrich, 1894

$$
\begin{aligned}
& \text { Macronotella? sp. } \\
& \text { Plate 10, figure } 1
\end{aligned}
$$

Description. - Lateral outline amplete; hingeline long, straight, anterior and posterior margins nearly equally curved, ventral margin evenly and deeply curved. Cardinal angles distinct, on flattened triangular areas which extend ventrally as narrow rim for about half height of valve; no marginal structures seen on ventral part of valve. Central valve surface has large, widely spaced punctae, marginal valve surface smooth.

Measurements. - The figured specimen is $0.775 \mathrm{~mm}$ long and $0.537 \mathrm{~mm}$ high.

Discussion. -This single specimen is questionably assigned to Macronotella Ulrich, 1894, because of its lateral outline and coarse punctation. As noted by Kesling and others (1960, p. 302-304), Macronotella scofieldi Ulrich, 1894 , the type species of the genus, is dimorphic, and the heteromorph has a striated velum; other species should not be placed in Macronotella unless dimorphism can be demonstrated. The single valve from Kentucky is presumably a tecnomorph, and a positive generic assignment cannot be made until a heteromorph is found. The specimen differs from $M$. scofieldi in being more sparsely punctate.

Types. - Figured specimen USNM 271042.

Occurrence.-The only specimen found is from the lowest foot of the Curdsville Limestone Member (Kirkfieldian) of the Lexington Limestone, Tyrone C section, USGS colln..5083-CO.

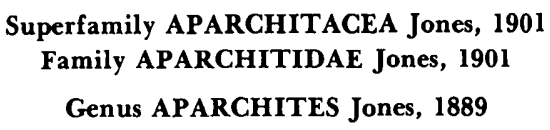

Type species. -Aparchites whiteavesi Jones, 1889.

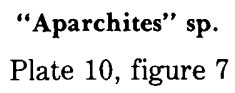

Description.-Lateral outline subelliptical, amplete; dorsal margin slightly sinuous, anterior and posterior margins smoothly curved, ventral margin very gently curved. Cardinal angles obtuse, hingeline slightly incised. Greatest length and height about at midpoint of valve, greatest width slightly posterior of midpoint. Valve surface smoothly curved in end view. Finely denticulate lateromarginal bend around free margin; denticles extend nearly to cardinal angles. Marginal surface plane. Shell smooth.

Measurements. - The single valve is $1.950 \mathrm{~mm}$ long and $1.350 \mathrm{~mm}$ high. 
Discussion. - This left valve belongs with the group of species typified by Aparchites? fimbriatus (Ulrich, 1892), but it appears to have smaller and more closely spaced spinules than those of the holotype (USNM 41834) of A.? fimbriatus, although it falls within the range of variation of the species, as illustrated by Swain, Cornell, and Hansen (1961, pl. 46, fig. 1). However, this single valve is considered inadequate for a definite specific identification.

As noted by Swartz (1969, p. 1237, 1238), the holotype of $A$. whiteavesi, the type species of Aparchites Jones, 1889 , shows a marginal thickening of both valves where the shell is preserved, but it lacks any indication of fimbriate or spinose marginal structures on either valve. Swartz (1969, p. 1239), therefore, suggested that Aparchites fimbriatus (Ulrich, 1892) and related species such as $A$. parsispinosus Kraft, 1962, should be removed from Aparchites and tentatively proposed that they be assigned to Hyperchilarina Harris, 1957. However, as discussed below, the holotype of $H$. ovata Harris, 1957, the type species of Hyperchilarina, has a sinuous ventral overlap and is probably not congeneric with $A$. fimbriatus. The genus Bullatella Swain and Cornell, 1961, is fimbriate or has marginal structures on both valves and, in addition, it has a midventral swelling, unlike Aparchites fimbriatus, which is fimbriate only on the left valve and is evenly curved in end view. Because there is no described genus in which the group of "Aparchites" fimbriatus can be placed, the generic name is given in quotes.

Types. - Figured specimen USNM 271045.

Occurrence. - The only specimen found was in the lowest foot of the Curdsville Limestone Member (Kirkfieldian) of the Lexington Limestone, Tyrone C section, USGS colln. 5083-CO.

\section{Genus BREVIDORSA Neckaja, 1973}

Type species.-Brevidorsa brevidorsata Neckaja, 1973.

\section{Brevidorsa strodescreekensis n. sp.}

Plate 10, figures 8-15.

Diagnosis.-Short hinged subcircular palaeocopes with "pillar structures" around free margin of smaller valve and fine punctae on the lateroventral slopes of both valves.

Description.-Lateral outline amplete, subcircular, valves subequal. Greatest length at midheight, greatest height just anterior of midlength and greatest width subcentral. Lateral valve surface smoothly rounded. Right valve larger than left and overlaps it around entire free margin. Very low, poorly defined velar ridge parallels contact margin of right valve lateroventrally. Left valve overreaches right on dorsal margin, concealing hingeline in left-lateral view. Shallow marginal depression rims left valve around entire contact margin and contains fine radiating ribs ("pillar structures" of Schallreuter, 1973, p. 41). Lateroventral surface of both adult valves finely punctate. Punctae lacking from laterodorsal surface of valves from central area to dorsal margin. Hingeline straight and approximately 55 percent of greatest length. Hingement not observed.

Measurements. - The dimensions of five paratypes and the holotype are given on table 18.

TABLE 18. - Measurements (in $\mathrm{mm}$ ) of six specimens of Brevidorsa strodescreekensis from USGS colln. No. 7318-CO, from the Strodes Creek Member of the Lexington Limestone

\begin{tabular}{|c|c|c|c|c|c|}
\hline & Type & USNM No. & Valve & Length & Height \\
\hline 1 & Holotype & 240051 & Left & 1.193 & 0.935 \\
\hline 2 & Figured paratype & 240052 & Right & 1.156 & .886 \\
\hline 3 & _-_._do & 240053 & _._._do & .910 & .677 \\
\hline 4 & Unfigured paratype & 240055 & Left & .923 & .689 \\
\hline 5 & ------do & 240055 & do & .984 & .763 \\
\hline 6 & do & 240055 & Right & 1.046 & .713 \\
\hline
\end{tabular}

Discussion. - The description of Brevidorsa strodescreekensis is mostly based on nine complete calcareous carapaces; although other specimens were also examined, most were embedded in limestone matrix and were only of marginal use.

Brevidorsa strodescreekensis most closely resembles four other species that also have pillar structures on the left valve; these are $B$. suborbicularis (Kraft, 1962) from the Middle Ordovician Edinburg Formation of Virginia; B. bella (Copeland, 1965) from the Middle Ordovician Bucke Formation of Ontario; and Brevidorsa sp. A and sp. B (Schallreuter, 1973) from the Ordovician of the Baltic area. B. strodescreekensis differs from $B$. suborbicularis in being less rounded in lateral view and having a relatively longer dorsal border; it differs from $B$. bella and Brevidorsa sp. B in being finely punctate. Brevidorsa sp. A of Schallreuter (1973, p. 45-46) is also punctate, but the overreach of the left valve over the right is apparently not as great as in $B$. strodescreekensis.

The holotype of $B$. strodescreekensis has some additional shell material attached to the posteroventral border. This material may represent fragments of a ventral row of spines, or a velar structure formed by the fusion of such spines, as illustrated by Schallreuter (1973, fig. 5A). Additional specimens will be necessary before the character of this structure can be determined.

Not enough specimens are available for an ontogenetic study, but apparently the younger instars lack punctae. No other ontogenetic trends were observed, except for a change in absolute size.

Neckaja $(1973$, p. 17) proposed the genus Brevidorsa for subcircular ostracodes with a short straight hingeline and with the right valve overlapping the left 
around the free margins but the left valve overreaching the right dorsally. A few months earlier, Schallreuter (1973) had discussed the relationship between the genera Hyperchilarina Harris, 1957, and Aparchites Jones, 1889 , and had included in Hyperchilarina several taxa that now appear to belong in Brevidorsa. Schallreuter (1973, p. 37) aptly commented on the difficulties of properly classifying smooth, essentially featureless ostracodes; among the more useful criteria for this purpose are the characters of the hingeline and free margin. Harris (1957, p. 143) considered that the diagnostic feature of his genus Hyperchilarina was that the larger valve overlapped the smaller around the entire free margin and overreached it dorsally; he also mentioned "beading" along the ventral margin of the smaller valve. In addition, the holotype (MCZ 4511; this report, pl. 10, figs. 3-5) of $H$. ovata Harris, 1957, the type species of Hyperchilarina, has a sinuous contact margin, the larger valve extending in a slight lappet over the smaller. In contrast, the contact margin of Brevidorsa is straight. Swartz (1969) redescribed and refigured the holotype (GSC 3838) of Aparchites whiteavesi Jones, 1889, the type species of Aparchites; although this specimen is unfortunately a mostly exfoliated steinkern, it appears to have a channelled free margin on both valves. Further clarification of the diagnostic characters of Aparchites must await that study of topotype specimens, but it appears unlikely that this genus will preoccupy either Brevidorsa or Hyperchilarina.

The genus Baltonotella Sarv, 1959, type species $B$. kuckersiana (Bonnema, 1909), appears to be quite similar to Brevidorsa. Sarv (1959, p. 161-162) considered some of the diagnostic characters of Baltonotella to be a coarsely punctate surface with a smooth central muscle scar and the left valve overlapping the right around the entire free margin. According to Sarv (oral commun., July 1979), Baltonotella lacks "pillar structures" on the left valve. Sarv did not discuss the character of the dorsal margin, but apparently the smaller valve does not overreach the larger as in Brevidorsa.

Sethi (1979, p. 143) has considered Brevidorsa Neckaja, 1973 (type species Brevidorsa brevidorsata Neckaja, 1973) to be a junior subjective synonym of Pseudoaparchites Krandijevsky, 1963 (type species Pseudoaparchites latus Krandijevsky, 1963), because Abushik (1971, p. 49) placed $P$. latus in synonymy with Leperditella gregaria Sarv, 1962, a species which Neckaja (1973, p. 17) conditionally included in Brevidorsa. However, as noted by Abushik (1971, p. 10), Krandijevsky's description and illustrations of $P$. latus are inadequate. Krandijevsky (1963, p. 20-21) did not describe any features on $P$. latus that could be interpreted as "pillar structures," but these appear to be present on Leperditella gregaria, according to Sarv (1962, p. 132). Consequently, we are provisionally considering Brevidorsa Neckaja, 1973, a valid genus until Krandijevsky's type material has been redescribed and refigured.

The specific name of Brevidorsa strodescreekensis is in reference to the restricted occurrence of this species in the Strodes Creek Member of the Lexington Limestone.

Types. - Holotype, an adult carapace, USNM 240051, from USGS colln. 7318-CO, Strodes Creek Member of the Lexington, $10 \mathrm{ft}$ above the base of Winchester Reference Section B. Figured paratypes, USNM 240052 and 240053; unfigured paratypes, USNM 240054 and 240055 (four carapaces on one slide), all from USGS colln. 7318-CO.

Occurrence. - This species is to date restricted to the Strodes Creek Member (Edenian) of the Lexington Limestone at two localities. One collection, USGS 7312-CO from Kentucky Route 89, contained four specimens. The other collection, USGS 7318-CO from Winchester Reference Section B, contained 21 specimens.

\section{Genus SACCELATIA Kay, 1940}

Type species. -Aparchites arrectus Ulrich, 1894.

\section{Saccelatia sp.}

Plate 10 , figure 2

Description.-Lateral outline amplete to slightly postplete; hingeline long and straight, anterior margin curved, ventral margin gently curved, posterior margin more broadly curved than anterior. Anterior cardinal angle more obtuse than posterior. Hingeline shorter than greatest length. Greatest length above midheight, greatest height at midlength. Distinct lateromarginal bend obscures contact margin ventrally in lateral view, well developed anteroventrally and posteroventrally but merges into valve surface and converges with contact margin dorsally. Contact margin obscurely denticulate. Shell surface smooth.

Measurements. -The figured specimen is $0.800 \mathrm{~mm}$ long and $0.500 \mathrm{~mm}$ high.

Discussion. - Only one right valve of this taxon has been found, but the denticulate contact margin and lateromarginal bend suggest that it belongs in Saccelatia Kay, 1940. It differs from $S$. arrecta (Ulrich, 1894) in having a more distinct lateromarginal bend; it differs from $S$. angularis (Ulrich, 1894) in having the bend obsolete dorsally. Saccelatia bullata Kay, 1940, S. cletifera Kay, 1940, and $S$. arcuamuralis Kay, 1940, all have flanges or nodes in the position of the lateromarginal bend, and S. buckensis Copeland, 1965, is punctate.

Types. - Figured specimen USNM 271043. 
Occurrence. - The single known specimen is from the lowest foot of the Curdsville Limestone Member (Kirkfieldian) of the Lexington Limestone, Tyrone C section, USGS colln. 5083-CO.

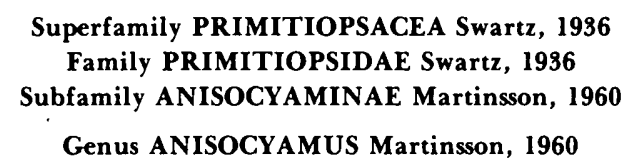

Type species. -Primitiopsis elegans Harris, 1957.

\section{Anisocyamus? sp.}

Plate 11, figures 7-9

Description. -Lateral outline postplete, subcuneate; hingeline straight, anterior margin strongly curved, ventral margin very gently curved, posterior margin nearly straight. Lateral surface nonsulcate but with posterior shoulder or bend parallel to posterior margin. Surface appears to be coarsely punctate.

Measurements.-A figured specimen, USNM 240018, is $1.239 \mathrm{~mm}$ long and $0.734 \mathrm{~mm}$ high.

Discussion. - Only three specimens were found, two of which, a right and a left valve, were picked from USGS colln. 7459-CO and are about the same size, so that only one individual may be represented. The posterior shoulder is reflected on the interior of the valve. The surface of both valves from USGS colln. 7459-CO is corroded and pitted by impressions of cubic crystals, so that the original character of the ornamentation is difficult to determine, but the one right valve from USGS colln. $7312-\mathrm{CO}$ is smooth. The only left valve is broken anteriorly and therefore could not be measured.

These specimens most closely resemble Anisocyamus excavatus (Harris, 1957) from the Tulip Creek Formation of Oklahoma, except that they are larger and more elongate. Harris (1957, p. 204-205) did not indicate whether he considered the holotype (MCZ 4595; this report, pl. 10, figs, 5,6 ) of $A$. excavatus to be a tecnomorph or a heteromorph, and this question cannot be resolved until more specimens are found. The Kentucky specimens are questionably assigned to Anisocyamus because of their resemblance to $A$. excavatus and because their lateral outline generally resembles that of species of Anisocyamus figured by Martinsson (1960), although $A$. excavatus may be a primitiopsid that does not belong in Anisocyamus.

Types.-Figured specimens, USNM 240018, 271047.

Occurrence.-Two specimens came from the Clays Ferry Formation (Edenian) at the Sadieville C locality, USGS colln. 7459-CO. One specimen is from the Strodes Creek Member (Edenian) of the Lexington Limestone at the Kentucky Route 89 locality, USGS colln. 7312-CO.
Suborder KLOEDENELLOCOPINA Scott, 1961 Superfamily LEPERDITELLACEA Ulrich and Bassler, 1906 Family LEPERDITELLIDAE Ulrich and Bassler, 1906 Genus LEPERDITELLA Ulrich, 1894

Type species.-Leperditella rex Coryell and Schenck, 1941.

Leperditella sp. aff. L tumida (Ulrich, 1892)

Plate 11, figure 10-14

1892. Leperditia tumida Ulrich, p. 265, pl. 9, figs. 1-3.

1894. Leperditella tumida (Ulrich). Ulrich, p. 636.

1934. Leperditella tumida (Ulrich). Bassler and Kellett, p. 375, (see for complete synonymy to this date).

1957. Leperditella tumida (Ulrich). Harris, p. 158, pl. 3, figs. 10a-10b.

Description. - Lateral outline postplete; dorsal outline slightly sinuous, anterior cardinal angle obtuse, anterior margin smoothly rounded, ventral margin broadly curved toward posterior, posterior margin more broadly curved than anterior, posterior cardinal angle rounded. Maximum length through midpoint of valve, maximum height in posterior third of valve, maximum width through or slightly behind midpoint of carapace. Left valve overlaps right ventrally, right valve slightly overreaches left dorsally. Hingeline weakly incised. Shell surface smooth.

Measurements. -A figured carapace (USNM 271048) is $1.012 \mathrm{~mm}$ long, $0.825 \mathrm{~mm}$ high, and $0.575 \mathrm{~mm}$ wide. The measurements of three other specimens are given in table 19.

TABLE 19.-Measurements (in $\mathrm{mm}$ ) of three specimens of Leperditella sp. aff. L. tumida (Ulrich), from the Lexington Limestone

\begin{tabular}{|c|c|c|c|c|c|}
\hline & Type & USNM Nंó. " & $\begin{array}{c}\text { USGS } \\
\ldots \text { colln. No. }\end{array}$ & Length & Height \\
\hline 1 & Unfigured specimen & 240046 & $4191-\mathrm{CO}$ & 1.082 & 0.750 \\
\hline 2 & -----do do & 240047 & $7455-\mathrm{CO}$ & .922 & .664 \\
\hline 3 & ----_do _------- & 240048 & $7071-\mathrm{CO}$ & .418 & .295 \\
\hline
\end{tabular}

Discussion.-The specimens from the Lexington Limestone and Clays Ferry Formation are similar in lateral outline to the syntypes (USNM 41310) of Leperditella tumida (Ulrich, 1892), which are here illustrated for comparison (pl. 11, figs. 18, 19); they are also like the specimen (MCZ 4529) from the Corbin Ranch Formation of Oklahoma identified as L. tumida by Harris (1957, p. 158-159, pl. 3, figs. 10a, b). However, they are less than half the size of these other specimens, and the anterodorsal leperitelloid "sag" is less well developed. Although closely related to $L$. tumida, the Lexington and Clays Ferry specimens may represent a new species, but unfortunately the preservation of the material at hand is too poor to determine whether or not this is true. In addition, one silicified left valve (USNM 
240046) has two poorly defined punctate depressions on the dorsocentral valve surface and a very narrow marginal rim around the entire free margin. As yet, the taxonomic significance of these features is not certain because they may be due to the type of preservation. The internal mold of an instar (USNM 240048) of this taxon shows a deep, long, narrow, centrally located groove which is not on the exterior of any of the other specimens and which may represent the impression. of an internal ridge used for muscle attachment.

Types.-Figured specimens USNM 271049, 271050, and a corroded carapace, USNM 271048; unfigured specimens USNM 240046-240048.

Occurrence.-A total of 35 specimens was collected from the following five USGS localities and 13 collections of Kirkfieldian to Edenian Age: Valley View B (Hunters Ferry Road), Grier Limestone Member of Lexington Limestone, 4191-CO (1); Dry Fork Road, Millersburg Member of the Lexington, 7040-CO (1), 7041-CO (7), Clays Ferry Formation, 7043-CO (8) Millersburg Member of the Lexington, 7068-CO (2), Tanglewood Limestone Member of the Lexington, 7071-CO (1); Sadieville C, Millersburg Member of the Lexington, 7454-CO (5), 7455-CO (1), Tanglewood Limestone Member of the Lexington, 7467-CO (4), Clays Ferry Formation, 7471-CO (2); Clays Ferry Type Section, Supplement, Clays Ferry Formation, D1170-CO (1), D1171-CO (1); Gratz A, Grier Limestone Member of the Lexington, D1309-CO (1).

\section{Leperditella? perplexa n. sp. \\ Plate 11, figure 1-4}

Diagnosis. - Small, postplete leperditelloid ostracodes with weakly incised hingeline and little overlap around free margins.

Description. - Lateral outline subtriangular; dorsal margin slightly sinuous, anterior margin sharply curved, ventral margin broadly and asymmetrically curved, posterior margin gently curved. Both cardinal angles obtuse. Greatest length at or slightly above midpoint of carapace, greatest height in posterior third and greatest width through midpoint of carapace. Shell surface smooth. Hingement and muscle scars not known.

Measurements. - Holotype, a carapace, USNM 271046; length, $1.050 \mathrm{~mm}$, height, $0.737 \mathrm{~mm}$, width, $0.500 \mathrm{~mm}$. Paratype right valve, USNM 240045; length, $0.764 \mathrm{~mm}$, height, $0.539 \mathrm{~mm}$.

Discussion.-The holotype and several other specimens of this species have the right valve overlapping the left around the free margins; however, one or two poorly preserved specimens, which appear to be conspecific with the holotype, have left-over-right overlap. Ulrich $(1894$, see 1897, p. 636$)$ defined the genus Leperditella as having the left valve overlapping the right. The overlap around the free margins of $L$.? perplexa is so slight that the valves might have shifted position relative to each other after burial, but because of the doubt about the character of the overlap, this species is only questionably assigned to Leperditella.

This species is superficially similar to Aparchites minutissimus var. trentonensis Ulrich, 1894, from the Decorah Shale of Minnesota. Swain, Cornell, and Hansen (1961, p. 371-372) have reversed the dorsalventral orientation of $A$. trentonensis and have placed the species in the genus Macrocyproides Spivey, 1939. The syntypes (USNM 41302) of M. trentonensis (Ulrich, 1894) are both right valves from which the overlap and hingement cannot be determined, but other specimens from the Decorah indicate that the orientation of Swain, Cornell, and Hansen is correct and that the species is properly assigned to Macrocyproides. However, the long straight margin of $L . ?$ perplexa is considered to be dorsal because there is no overlap along it and it is weakly incised; the species is consequently oriented as a palaeocope.

Some unnumbered specimens in the U.S. National Museum of Natural History collections that were identified as "Aparchites minutissimus (Hall, 1872)" in Ulrich's handwriting, from the lower part of the Kope Formation at Cincinnati, Ohio, are very like $L$.? perplexa and may belong to this species. They are not assigned to Hall's species because Hall $(1872$, p. 231$)$ described his Leperditia (Isochilina) minutissima as having the "Surface of valves smooth, rising into an obtusely pointed prominence at the anterior third of the length," whereas the surface of the specimens under discussion is relatively flat.

Types.-Holotype, USNM 271046, from the Millersburg Member of the Lexington Limestone, USGS colln. 7043-CO; paratype, USNM 240045, from the Millersburg Member of the Lexington, USGS colln. 7039-CO.

Occurrence.-Eight specimens of L.? perplexa have been recovered from the following two USGS localities and four collections of Edenian Age: Dry Fork Road section, Millersburg Member of Lexington Limestone, 7039-CO (4), Clays Ferry Formation, 7043-CO (1); Sadieville B section, Millersburg Member of the Lexington, 7455-CO (2), Clays Ferry Formation, 7471-CO (1). Possibly this species also ranges into the Kope Formation.

\section{Leperditella? sp. cf. L.? canalis Ulrich, 1894}

Plate 11, figure 17

1894. Leperditella canalis Ulrich, p. 637, pl. 43, figs. 1-3.

1934. Leperditella canalis Ulrich. Bassler and Kellett, p. 373 (see for complete synonymy to this date). 
Description. - Lateral outline nearly amplete; dorsal margin straight, free margins smoothly rounded. Greatest length, height, and width through midpoint of valve. Cardinal angles obtuse. Ventral and end margins overhang contact margin in smooth curve, dorsum flattened. Shell surface smooth.

Measurements. -The figured specimen is $2.175 \mathrm{~mm}$ long and $1.600 \mathrm{~mm}$ high.

Discussion. - This taxon is represented in our collections by one complete but broken valve and one incomplete valve; because of the almost amplete outline and lack of distinguishing features, it is not even certain whether the single complete specimen is a right or a left valve. The specimen most closely resembles Leperditella? canalis Ulrich, 1894 (USMN 41304; this report, pl. 11, figs. 15, 16) but differs in having a less distinct ventral overhang of the lateral surface and in lacking an incised hinge line. Both this taxon and $L$. canalis differ from typical species of Leperditella in lacking a welldeveloped anterodorsal "sag" and in the presence of the ventral overhang, but without additional material, they cannot definitely be assigned to any other genus.

Types. - Figured specimen, USNM 271051.

Occurrence. - Two specimens were found in the following USGS localities and collections of Edenian Age: Kentucky Route 89 section, Strodes Creek Member of Lexington Limestone, 7312-CO (1), U.S. Route $227 \mathrm{sec}$ tion, Strodes Creek Member of Lexington, 7325-CO (1).

Genus BYRSOLOPSINA Swain and Cornell, 1961

Type species.-Paraschmidtella planilateralis Kay, 1940 .

\section{Byrsolopsina? sp.}

Plate 12 , figure 1

Description.-Lateral outline subelliptical, amplete; dorsal margin nearly straight, anterior and posterior margins evenly curved, ventral margin gently curved. Greatest length, greatest height and greatest width about through midpoint of valve. Cardinal angles rounded, hinge apparently long. Low node, posterior to which are two shallow pits, in posteroventral quarter of valve. Valve surface coarsely punctate except around margins. Narrow marginal rim questionably present around ends and part of ventral margin.

Measurements. -The single specimen is $0.473 \mathrm{~mm}$ long and $0.282 \mathrm{~mm}$ high.

Discussion. - The above description is based on one poorly preserved phosphatic valve, which may be a subinternal mold. The specimen has been oriented and described as though it were a right valve, although the node and the two pits could be anterodorsal rather than posteroventral. However, these features may be artifacts of preservation and without significance. The marginal rim may also be an artifact of preservation.
This specimen most closely resembles species of the genus Byrsolopsina Swain and Cornell, 1961, from the Decorah Shale of Minnesota, but although Byrsolopsina is coarsely punctate and has a similar outline, it lacks the node and pits of the Kentucky specimen. This specimen cannot be assigned unequivocally to a genus because of the poor preservation.

Types. - Figured specimen USNM 240015.

Occurrence. -The specimen is from the Curdsville Limestone Member (Kirkfieldian) of the Lexington Limestone, Nicholasville 1 (Denny Core), USGS colln. 5899-CO.

\section{Genus SCHMIDTELLA Ulrich, 1892}

Type species. -Schmidtella crassimarginata Ulrich, 1892.

Discussion. - A thorough redescription of the genus Schmidtella is beyond the scope of this paper; however, because of a certain confusion in the literature concerning the characters and classification of this genus, it has seemed desirable to reillustrate the type specimens of $S$. crassimarginata Ulrich, 1892 (pl. 12, figs. 19, 20). Classed with the Leperditiidae by Ulrich (1894), Schmidtella was transferred to the family Aparchitidae by Ulrich and Bassler (1923, p. 296-297). Bassler and Kellett (1934) assigned Schmidtella to the family Leperditellidae, and this assignment was followed by Kay (1940), Keenan (1951), Harris (1957), Jaanusson (1957), Levinson (in Moore, 1961), Swain, Cornell, and Hansen (1961), Burr and Swain (1965), Copeland (1973, 1974) and questionably by Kraft (1962). However, Drake (1940) suggested in an abstract that Eridoconcha Ulrich and Bassler, 1923 was a "molting stage" of Schmidtella Ulrich, 1892. Levinson (1951, p. 558) and Keenan (1951, p. 563-564) referred to Drake's study and also considered Schmidtella closely related to, although not synonymous with, Eridoconcha. Consequently, Henningsmoen (1953a, p. 255-256) included Schmidtella in his ?Subfamily Eridoconchinae. Adamczak (1961, p. 70-71) proposed a new suborder Eridostraca with two families, Eridoconchidae Henningsmoen, 1953, and Cryptophyllidae Adamczak, 1961; Schmidtella was placed in the latter. Rome and Goreux (1960, p. 192), however, had already noted that the evidence for the retention of molts in the genus Schmidtella was unsatisfactory and inconclusive.

Neckaja (1966, p. 7-8) proposed the family Schmidtellidae and the subfamily Schmidtellinae, in which she included, in addition to Schmidtella, Paraschmidtella Swartz, 1936, Hemiaechminoides Morris and Hill, 1952, and possibly Aparchitellina Polenova, 1955, Kayina Harris, 1957, and Bassleratia Kay, 1934; she did not indicate any relationship to Eridoconcha. Schallreuter (1968, p, 108-109), in discussing the tax- 
onomy of the Eridostraca, included the Schmidtellidae and Schmidtella in this suborder, although he mentioned that typical species of Schmidtella showed no retention of molts except for a groove that he considered to be caused by the next youngest larval stage.

As yet, no unequivocal evidence has been published that the retention of molt stages in Schmidtella is other than an occasional phenomenon, as documented for other unrelated ostracode genera (Martinsson, 1962, p. 86 ) or that species in which the molt stages are persistently retained are properly assigned to Schmidtella. Furthermore, Schallreuter (1968, p. 106) considered the presence of a sulcus or a sulcament (Schallreuter, 1967, p. 626) characteristic of the Eridostraca; this feature is lacking in Schmidtella, as represented by the type species, S. crassimarginata Ulrich, 1892 (pl. 12, fig. 20). For these reasons, Schmidtella is considered unrelated to the Eridostraca and is retained within the family Leperditellidae. The validity of the family Schmidtellidae Neckaja, 1966, must depend on further study of the genera composing this family.

\section{Schmidtella brevis Ulrich, 1894}

Plate 12, figs. 11-16

1894. Schmidtella brevis Ulrich, p. 642 , pl. 45 , figs. $34 ; 35$.

1934. Schmidtella brevis Ulrich. Bassler and Kellett, p. 471 (see for synonymy to date).

1940. Schmidtella brevis Ulrich. Kay, p. 241-242, pl. 29, figs. 7, 8.

1957. not Schmidtella brevis Ulrich. Harris, p. 164-165, pl. 4, figs. $10 \mathrm{a}-\mathrm{c}$.

1961. Schmidtella brevis Ulrich. Swain, Cornell, and Hansen, p. 360, pl. 48 , figs. $5 \mathrm{a}$, b.

Description.-Lateral outline amplete, subovate; greatest height at midlength, greatest length ventral of midheight, and greatest width at umbo. Dorsum slightly epicline and umbonate, cardinal angles rounded. Hingeline less than half length of valve, short and straight. Shell surface smooth. Hingement tongue and groove. Muscle scars not observed.

Measurements. - The length and height of eight specimens from USGS colln. 7455-CO are given in table 20.

Discussion. - Some of the specimens here assigned to $S$. brevis Ulrich, 1894, are relatively more elongate than the holotype (USNM 41299; pl. 12, fig. 13), but because these longer forms appear to grade into the more typical shape of $S$. brevis in the same collection, all are considered to belong to this species.

Most of the specimens are disarticulated corroded valves; only five carapaces were recovered. Unfortunately, all the carapaces are slightly sheared, so that the nature of the overlap, degree of incision of the hinge, and true width of the carapace cannot be accurately determined.

As noted by Ulrich (1894; see 1897, p. 642), Schmidtella brevis is similar to $S$. sublenticularis (Jones, 1890) but differs from the hypotypes figured by
TABLE 20.-Measurements (in $\mathrm{mm}$ ) of eight specimens of Schmidtella brevis from USGS colln. No. 7455-CO, from the Millersburg Member of the Lexington Limestone

[Specimen 1, USNM 240025; specimens 2-8, USNM 240026]

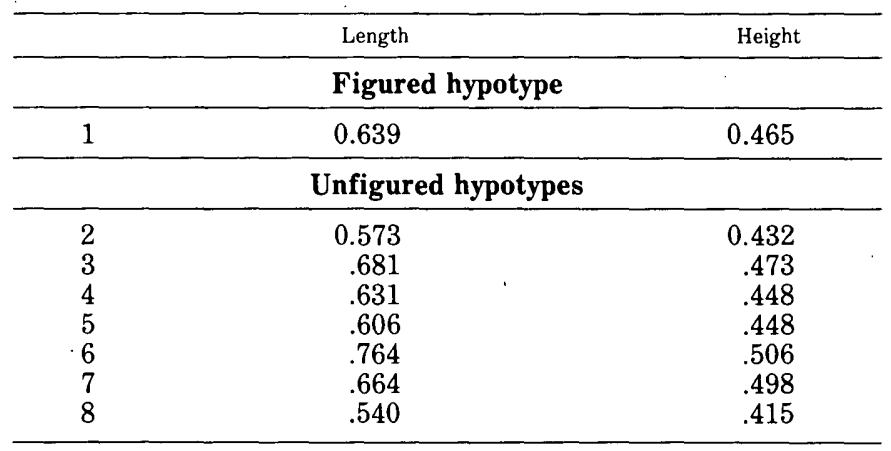

Copeland $(1973$, pl. 6, figs. $21,22,28,29)$ in having a more gently curved ventral outline, the maximum length more ventrally located, and a more centrally located umbo. S. brevis differs from $S$. crassimarginata Ulrich, 1892, S. affinis Ulrich, 1894, and S. umbonata Ulrich, 1894, in lacking a flattened area along the ventral part of the free margin. The two specimens (MCZ 4536, MCZ 4537) from the Tulip Creek Formation of Oklahoma assigned to $S$. brevis by Harris (1957, p. 164-165) are both more strongly inflated than are either the holotype of $S$. brevis or the specimens from Kentucky, and are considered to belong to another species.

Types.-Holotype, USNM 41299; figured hypotypes, USNM 240025, 271053, 271054; unfigured hypotypes (eight specimens on one slide), USNM 240026.

Occurrence. - The holotype is from the lower part of the Decorah Shale (Rocklandian) near Fountain, Minn.; specimens from Kentucky have been found in the Lexington Limestone (Millersburg and Strodes Creek) and the Clays Ferry Formation, all of Edenian Age.

A total of 48 specimens was collected from the following five USGS localities and 13 collections: Dry Fork Road, 7043-CO (3), 7046-CO (1), 7054-CO (2); Kentucky Route 89, 7312-CO (1); U.S. Route 227, 7325-CO (2); Sadieville C, 7454-CO (9), 7455-CO (10), 7456-CO (2), 7458-CO (1), 7468-CO (8), 7471-CO (4), 7477-CO (2); Clays Ferry Type Section, Supplement, D1171-CO (3).

\section{Schmidtella umbonata Ulrich, 1894 \\ Plate 12 , figures 17,18}

1894. Schmidtella umbonata Ulrich, p. 641, pl. 45, figs. 36-38.

1934. Schmidtella umbonata Ulrich. Bassler and Kellett, p. 472 (see for synonymy to date).

1940. not Schmidtella umbonata Ulrich. Kay, p. 242, pl. 29, figs. 9-11. 1961. not Schmidtella umbonata Ulrich. Swain, Cornell, and Hansen, p. 359 , pl. 48, fig. 3, see Schallreuter, 1967, p. 626.

Description. - Lateral outline subovate to subcircular; dorsal margin sharply curved to subangular, umbonate, anterior margin smoothly curved, ventral margin gently 
curved, posterior margin smoothly curved. Hingeline straight, slightly more than half greatest length, incised below umbo. Greatest length slightly below midheight, greatest height at midlength, greatest width above midheight. Narrow flattened rim around free margin, best developed on anterior and posterior margins, may be obsolete ventrally. Shell surface smooth.

Measurements. -The lectotype, here designated as USNM 41301a, is $0.825 \mathrm{~mm}$ long and $0.575 \mathrm{~mm}$ high. A hypotype from Kentucky, USNM 271055, is $0.875 \mathrm{~mm}$ long and $0.700 \mathrm{~mm}$ high.

Discussion. - One specimen (USNM 271055, pl. 12, fig. 18) from the Lexington Limestone appears to fall within the range of variation of the type collection (USNM 41301) of Schmidtella umbonata Ulrich, 1894. This specimen, a single left valve, is preserved in limestone and has the flattened rim only on the anterior and posterior margins.

The type collection of $S$. umbonata consists of 11 specimens glued to a strip of cardboard on which is written "Cotypes, 41,301-Schmidtella umbonata UlrichBlack River - Phylloporina bed, St. Paul, Minn." One of these is a specimen of Eridoconcha and does not belong with the other 10 specimens. In order to stabilize the binomen Schmidtella umbonata Ulrich, 1894, and to prevent the possibility of future confusion, a lectotype (USNM 41301a, pl. 12, fig. 17) is here designated from among the other 10 specimens.

Kay (1940, p. 242) assigned forms to Schmidtella umbonata that he described as "having faint dorsally directed umbonal depression corresponding to internal partition frequently evidenced by translucent area from exterior." He did not describe any marginal rim, which Ulrich (1894; see 1897, p. 641) considered characteristic of S. umbonata. Swain, Cornell, and Hansen (1961, p. 359) followed Kay's description and assigned specimens similar to his to $S$. umbonata. The lectotype and paralectotypes of $S$. umbonata appear to lack the structure (sulcament?) described by Kay but have the marginal rim mentioned by Ulrich. Probably the material described by Kay, as well as that of Swain, Cornell, and Hansen, as suggested by Schallreuter (1967, p. 626), belongs to a new species of Easchmidtella Schallreuter, 1967.

Types. - Lectotype, USNM 41301a; paralectotypes, USNM 41301 (except USNM 41301x); hypotype, USNM 271055.

Occurrence. - The lectotype and paralectotypes of Schmidtella umbonata are from the Ion Dolomite Member of the Decorah Formation at St. Paul, Minn. The figured hypotype is from the lowest foot of the Curdsville Limestone Member of the Lexington Limestone, Tyrone C section, USGS colln. 5083-CO.
Genus EASCHMIDTELLA Schallreuter, 1967

Type species. -Easchmidtella crassiumbonata Schallreuter, 1967.

Easchmidtella sinuidorsata n. sp.

Plate 12, figures 2-10

Diagnosis.-Outline of dorsal margin sinuous in lateral view, umbo high, dorsum epicline, lateral outline postplete.

Description.-Lateral outline subelliptical; anterior margin sharply curved, ventral margin smoothly curved, posterior margin broadly rounded, dorsal margin sinuous. Greatest height just posterior of midlength, greatest length dorsal of midheight, greatest width just posterior of midlength. Valves nearly equal, left valve overlaps right slightly around free margins. Ventral and anteroventral parts of both valves have distinct rounded right-angled bend, so that ventral surface of carapace is slightly flattened. Short straight hingeline incised, concealed by prominent broad umbo in lateral view. Narrow sulcament in dorsal half of valve visible on some translucent specimens. Details of hinge not known. Shell surface smooth.

Measurements. - The holotype carapace is $0.925 \mathrm{~mm}$ long, $0.725 \mathrm{~mm}$ high, and $0.575 \mathrm{~mm}$ wide. A paratype carapace (USNM 240050 ) is $0.850 \mathrm{~mm}$ long, $0.650 \mathrm{~mm}$ high, and $0.525 \mathrm{~mm}$ wide. A slightly longer paratype carapace (USNM 240050a) is $0.875 \mathrm{~mm}$ long, $0.650 \mathrm{~mm}$ high, and $0.525 \mathrm{~mm}$ wide. All measured specimens are from USGS colln. 7312-CO.

Discussion.-Although this species is more asymmetrical than most species assigned to Easchmidtella by Schallreuter (1967, p. 626), it is considered to belong to this genus because of its high umbones and the presence of a sulcament in each valve. Schallreuter (1967, p. 627) distinguished his genus Easchmidtella from Schmidtella Ulrich, 1892, on the basis of the admarginal groove, which is present in Schmidtella crassimarginata Ulrich, 1892, but lacking in Easchmidtella. This character is here considered to be of specific rather than generic value, whereas the presence of a sulcament in Easchmidtella and its absence in Schmidtella s.s. is believed to be a more valid means of distinguishing the genera.

The asymmetrical, almost leperditelloid lateral outline of Easchmidtella sinuidorsata is similar to that of Pullvillites? wabiensis Copeland, 1965, which also appears to have a sulcament. However, Copeland (1965, p. 48) described his species as having a pronounced ventral overlap, unlike E. sinuidorsata. Schmidtella asymmetrica Harris, 1957, lacks the prominent umbo of $E$. sinuidorsata. The lateral outline of $E$. sinuidorsata distinguishes it from most species assigned to Easchmidtella or Schmidtella. 
The specific name sinuidorsata refers to the sinuous outline of the dorsum in lateral view.

Types.-Holotype, a complete carapace, USNM 240049 from the Strodes Creek Member of the Lexington Limestone, Kentucky Route 89, USGS colln. 7312-CO. Paratypes, USNM 240050, 240050a, also from USGS colln. 7312-CO, and USNM 271052, from USGS colln. 7325-CO.

Occurrence. - This species is restricted to the Edenian Strodes Creek and Millersburg Members of the Lexington Limestone in the southeastern collecting area. The material studied consists of 68 specimens, some of which are not well preserved, from the following three USGS localities and eight collections: Dry Fork Road, 7047-CO (4), 7050-CO (18), 7053-CO (8), 7054-CO (11), 7059-CO (6), 7060-CO (3); Kentucky Route 89, 7312-CO (10); U.S. Route 227, 7325-CO (8).

Genus LACCOPRIMITIA Ulrich and Bassler, 1923

Type species.-Primitia centralis Ulrich, 1890, by original designation (Ulrich and Bassler, 1923, p. 300).

Species included.-Primitia rudis Ulrich, 1890.

Milleratia shideleri Levinson, 1951.

Eridoconcha elegantula Keenan, 1951.

Laccoprimitia cryptomorphologica n. sp.

Laccoprimitia claysferryensis $n$. sp.

Revised diagnosis.-Palaeocope ostracodes with subcentral flattened node or boss in adductorial pit, inflated dorsum, and rounded bend above rimlike marginal structure.

Discussion.-Ulrich and Bassler (1923, p. 300) diagnosed Laccoprimitia as having a single subcircular pit, a border around the free margin, and no nodes. The revised diagnosis given here, based on the holotype (USNM 41337, pl. 14, fig. 8) of Laccoprimitia centralis, emphasizes additional characters such as the node that fills the central pit and the inflated dorsum, which were not mentioned by Ulrich and Bassler. Because these features were not included in the original diagnosis and were not shown on the original figure (Ulrich and Bassler, 1923, p. 298, text-fig. 15-4), some European species of Laccoprimitia probably belong to other genera, as suggested by Hessland (1949, p. 231). The genus Lacccoprimitia appears to be closely related to Milleratia Swartz, 1936. However, the type species of Milleratia, M. cincinnatiensis (Miller, 1875), has a deep lachryform median sulcus (pl. 14, fig. 6), whereas species of Laccoprimitia, if sulcate, have a very narrow shallow sulcus. Species of Laccoprimitia are listed in Cressman (1973) as Milleratia.
Geologic range:-Middle and Upper Ordovician (Shermanian-Richmondian) of east-central North America.

\section{Laccoprimitia centralis (Ulrich)}

Plate 14, figure 8

1890. Primitia centralis U.lrich, p. 130-131, pl. 10, figs. 1, 2a-c. 1893. Primitia centralis Ulrich. Jones, p. 291 , pl. 12 , figs. la-c. 1915. Primitia centralis Ulrich. Bassler, p. 1029.

1923. Laccoprimitia (Primitia) centralis (Ulrich). Ulrich and Bassler, p. 299, 300, fig. 15-4.

1924. Laccoprimitia centralis (Ulrich). Foerste, p. 254, pl. 45, fig. 3. 1926. Primitia centralis Ulrich. Ruedemann, p. 138-139, pl. 23, fig. 7 . 1934. Laccoprimitia centralis (Ulrich). Bassler and Kellett, p. 372

1965. Laccoprimitia centralis (Ulrich). Burr and Swain, p. 7.

Diagnosis. - Adductorial node small; weak sulcus extends dorsally from it. Velar bend obscure and rounded.

Description. - Lateral outline subovate, postplete; in lateral view, dorsal margin slightly sinuous, anterior margin sharply curved, ventral margin gently curved, posterior margin broadly curved. Hingeline straight, incised, posterior part of valve inflated. Adductorial node small, lachriform, slightly anterior of midlength, surrounded by narrow sulcus, which extends dorsally as indistinct sag. Velar bend rounded and indistinct, does not conceal narrow marginal rim that extends from midheight on anterodorsal margin to posterior cardinal angle. Cardinal angles obtuse. Shell surface smooth.

Measurements. - The holotype (USNM 41337) is 0.650 $\mathrm{mm}$ long and $0.425 \mathrm{~mm}$ high, as measured by Berdan.

Discussion. - The above revised description is based on the holotype (USNM 41337; pl. 14, fig. 8); the posterior extent of the marginal rim was seen on a topotype specimen on the same chip of rock as the holotype. The paratype specimen (USNM 41338) listed in Bassler and Kellett (1934, p. 372) has a deeper sulcus and may not be conspecific with the holotype. No specimens that can be unequivocally assigned to this species have been found in the USGS collections from the Lexington Limestone and the Clays Ferry Formation. Ulrich (1890, p. 130-131) stated that his species was "not uncommon in the Utica shales near low water mark in the Ohio River, in the vicinity of Cincinnati, O.," which in current terminology would imply that it came from the Edenian Kope Formation. However, the label with the holotype reads "Trenton gr., Ohio river bed, Covington, Ky.," in Ulrich's handwriting, which suggests that the specimen might have come from the Point Pleasant Tongue of the Clays Ferry Formation. Because of the possibility that it may be found in the Clays Ferry, and because it is the type species of Laccoprimitia, it has seemed desirable to include a description of $L$. centralis in this paper. 
Occurrence.-Either in the Point Pleasant Tongue (Shermanian) of the Clays Ferry Formation or in the Kope Formation (Edenian), bed of the Ohio River at Covington, Ky., and Cincinnati, Ohio.

\section{Laccoprimitia rudis (Ulrich)}

Plate 13, figures 1, 4; plate 14, figures 9-19

1890. Primitia rudis Ulrich, p. 136, pl. 10, figs. 8a-c. 1915. Primitia rudis Ulrich. Bassler, p. 1032.

1926. Primitia rudis Ulrich. Ruedemann, p. 139, pl. 23, figs. 3-5. 1934. Primitia rudis Ulrich. Bassler and Kellett, p. 454.

Diagnosis.-Relatively elongate, narrow S2 bifurcating and surrounding large adductorial node. Velar bend poorly defined, rounded, bordered dorsally by indistinct, coarsely punctate groove.

Description.-Lateral outline amplete to slightly postplete, subovate. Greatest height posterior to midlength, greatest length at midheight, greatest width posterior to midheight. Dorsal margin umbonate, concealing incised hingeline which is straight and approximately 60 percent of greatest length. Anterior margin subelliptical in outline, grades into broadly convex ventral margin, which in turn grades into broadly rounded posterior margin. Cardinal angles obtuse and poorly defined; anterior cardinal angle greater than posterior angle. Shallow S2 divides umbo into two lobes, of which posterior is wider and extends slightly higher above hingeline. S2 anterior of midlength, moderately deep, extends about 30 percent of distance to venter. Ventral part of S2 bifurcates and encircles large, subcentral, low adductorial node.

Poorly defined, rounded velar bend subparallel to free margin, which flares out in marginal rim. In lateral view, marginal rim extends past velar bend on anteroventral, ventral, and posteroventral margins. Velar bend and marginal rim coalesce just ventral of anterior and posterior cardinal angles. Fairly deep wide channel between marginal rim and velar bend. Velar bend defined dorsally by indistinct, coarsely punctate groove, remainder of valve smooth or has scattered punctae. S2 and adductorial node reflected on interior of valve as inverse features. Hingement apparently weak groove in right valve into which edge of left valve fits.

Measurements.-As measured by Berdan, the holotype (USNM 41345 ) is $0.850 \mathrm{~mm}$ long and $0.475 \mathrm{~mm}$ high. The measurements of 20 randomly picked (with the aid of a random number table) specimens from USGS colln. 7468-CO are given in table 21.

Discussion. - The elongate outline and coarsely punctate groove dorsal to the velar bend distinguish $L$. rudis from other species assigned to Laccoprimitia. The holotype of $L$. rudis (USNM 41345, pl. 14, fig 9), which is presumably from the Kope Formation, is in close agreement with many of the specimens from the Lex-
TABLE 21.-Measurements (in $\mathrm{mm}$ ) of 20 randomly picked specimens of Laccoprimitia rudis (USNM Nos. 240013, 271059, 271060, and 271062) from USGS colln. No. 7468-CO, from the Clays Ferry Formation

\begin{tabular}{|c|c|c|c|}
\hline & Valve & Length & Height \\
\hline 1 & Left & 0.663 & 0.416 \\
\hline 2 & --_-_do _...- & .728 & .507 \\
\hline 3 & Right & .702 & .468 \\
\hline 4 & $-{ }_{-}$do & .611 & .416 \\
\hline 5 & Left & .468 & .312 \\
\hline 6 & _-_do _------_- & .689 & .429 \\
\hline 7 & Right & .702 & .494 \\
\hline 8 & Left & .624 & .403 \\
\hline 9 & Right & .585 & .429 \\
\hline 10 & Left & .585 & .403 \\
\hline 11 & Right & .585 & .429 \\
\hline 12 & _--_-_ do _--- & .546 & .403 \\
\hline 13 & - & .624 & .429 \\
\hline 14 & - & .663 & .442 \\
\hline 15 & 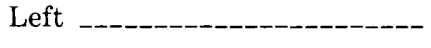 & .585 & .416 \\
\hline 16 & -'-_-_do _--_--_- & .650 & .377 \\
\hline 17 & _-_-_ do _ _- & .702 & .468 \\
\hline 18 & - $-\ldots$ do & .598 & .403 \\
\hline 19 & Right & .650 & .429 \\
\hline 20 & - & .689 & .468 \\
\hline
\end{tabular}

ington Limestone and the Clays Ferry Formation, although it is more umbonate. However, the population of $L$. rudis studied for this report is extremely variable in lateral outline, and the more inflated umbo of the type is not considered to be a specific difference.

Ulrich (1890, p. 136) described Laccoprimitia rudis as having a "faintly defined tubercle or lobe" in front of the sulcus and between it and the dorsal margin. This feature does not appear to exist on the holotype. According to Ulrich $(1890$, p. 136), this species is rare in the shales of the "lower one hundred feet of the Cincinnati Group" at Covington, Ky., which suggests that the types came from the Kope Formation of current terminology.

Ruedemann (1926, p. 139, pl. 23, figs. 3-5) described and figured specimens that he identified as "Primitia rudis" from his Whetstone Gulf Formation of New York; these specimens have not been seen by us, but the material (USNM 34536) mentioned by Ruedemann (1926, p. 139) as coming from near Rome, N.Y., is not identifiable.

Types.-Holotype, USNM 41345; figured hypotypes, USNM 240010, 240011, 240012, 271059-271063; unfigured hypotypes (17 measured specimens) USNM 240013.

Occurrence-In addition to its occurrence in the Edenian of the Cincinnati area (Ulrich, 1890; Warshauer, 1980) and reported presence in the Utica Shale of New York, this species has been found in the Lexington Limestone (Grier, Millersburg, and Tanglewood) and in the Clays Ferry Formation. It appears to range in age from Shermanian(?) to Edenian. 
Approximately 470 specimens were recovered from the following four USGS localities and 20 collections: Clays Ferry Type Section, Supplement, D1169-CO (3), D1171-CO (2); Gratz A, D1309-CO (3); Dry Fork Road, 7041-CO (4), 7045-CO (4), 7047-CO (6), 7050-CO (4), 7055-CO (2), 7056-CO (3), 7059-CO (6), 7060-CO (3), 7068-CO (9); Sadieville C, 7462-CO (118), 7467-CO (61), 7468-CO (95), 7471-CO (67), 7472-CO (1), 7477-CO (4), $7478-\mathrm{CO}(41), 7454-\mathrm{CO}(33)$.

\section{Laccoprimitia cryptomorphologica n. sp.}

Plate 13 , figures $2,3,5,6$; plate 14 , figures $20-27$

Diagnosis. - Characterized by extremely subtle development of S2, sulcal node, and velar bend.

Description.-Lateral outline slightly postplete, subovate, valves equal in size. Dorsal margin somewhat umbonate, concealing hingeline, which is straight and approximately 60 percent of greatest length. Ventral margin broadly convex, grading into rounded anterior and bluntly rounded posterior margins. Greatest height posterior to midlength, greatest length slightly ventral to midheight, greatest width posterior to midlength. Cardinal angles obtuse and subequal; anterior angle less well defined than posterior. Dorsal umbo divided into two unequal lobes by shallow obscure S2; posterior lobe extends higher above hingeline than does anterior lobe. S2 is slightly anterior of midlength, may grade ventrally into shallow subcircular depression or may end in very obscure adductorial node. Velar bend rounded, subdued, does not conceal marginal rim in lateral view, developed only parallel to ventral margin. Fairly wide channel between velar bend and marginal rim. Shell surface apparently smooth. Hingement apparently weakly developed tongue and groove.

Measurements. - The length and height of the holotype and 63 paratypes are given in table 22 . A statistical summary of the meaurements for each of the growth stages is shown in table 23 .

Ontogeny. - The plotting of a size-dispersion diagram (fig. 20) has led to the recognition of five growth stages, the adult through adult-4 (A-4). Unfortunately two of the instars, A-2 and A-3, are represented by only one specimen each and are therefore poorly understood. Delineation of the five stages was greatly enhanced by the separate plotting of left and right valves. Because of the conservative morphologic features shown by this species, ontogenetic changes are limited to the expected changes in absolute size, changes in valve shape, and changes in the development of the velar bend. In the smallest instar yet recovered, A-4, the shape of the valve is less umbonate than in the adult, and the velar bend and S2 are nonexistent. In the A-1 stage, rudiments of the velar bend, S2, and the adductorial node are evident. The A-2 and A-3 instars, although poorly understood, seem to be intermediate in morphologic development between the A-1 and A-4 stages.
TABLE 22.-Measurements (in $\mathrm{mm}$ ) of 64 specimens of Laccoprimitia cryptomorphologica from USGS colln. No. 7455-CO, from the Millersburg Member of the Lexington Limestone

[Specimens 1-4, respectively, USNM 239995-239998; specimens 5-64, USNM 239999]

\begin{tabular}{|c|c|c|c|}
\hline & Valve & Length & Height \\
\hline \multicolumn{4}{|c|}{ Holotype } \\
\hline 1 & 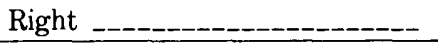 & 0.813 & 0.574 \\
\hline \multicolumn{4}{|c|}{ Figured paratypes } \\
\hline $\begin{array}{l}2 \\
3 \\
4 \\
\end{array}$ & $\begin{array}{l}\text { Right } \\
\text { Left }-1-\end{array}$ & $\begin{array}{r}0.772 \\
.764 \\
.697 \\
\end{array}$ & $\begin{array}{r}0.519 \\
.519 \\
.419 \\
\end{array}$ \\
\hline \multicolumn{4}{|c|}{ Unfigured paratypes } \\
\hline $\begin{array}{r}5 \\
6 \\
7 \\
8 \\
9 \\
10\end{array}$ & 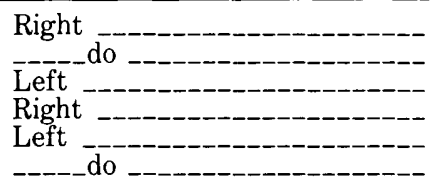 & $\begin{array}{r}0.784 \\
.797 \\
.674 \\
.755 \\
.759 \\
.726\end{array}$ & $\begin{array}{r}0.531 \\
.556 \\
.423 \\
.540 \\
.531 \\
.527\end{array}$ \\
\hline $\begin{array}{l}11 \\
12 \\
13 \\
14 \\
15 \\
16\end{array}$ & 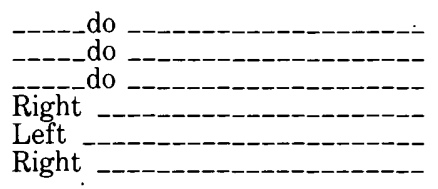 & $\begin{array}{l}.714 \\
.739 \\
.708 \\
.776 \\
.693 \\
.569\end{array}$ & $\begin{array}{l}.531 \\
.515 \\
.473 \\
.548 \\
.498 \\
.390\end{array}$ \\
\hline $\begin{array}{l}17 \\
18 \\
19 \\
20 \\
21 \\
22\end{array}$ & 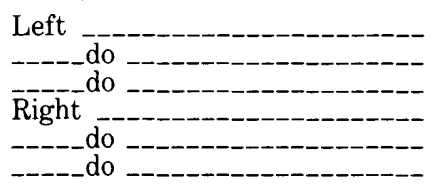 & $\begin{array}{l}.747 \\
.757 \\
.708 \\
.714 \\
.706 \\
.772\end{array}$ & $\begin{array}{l}.481 \\
.508 \\
.483 \\
.457 \\
.461 \\
.506\end{array}$ \\
\hline $\begin{array}{l}23 \\
24 \\
25 \\
26 \\
27 \\
28\end{array}$ & 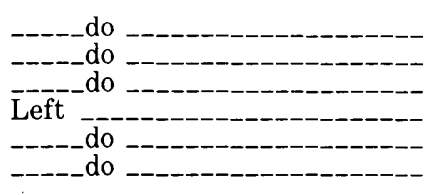 & $\begin{array}{l}.797 \\
.652 \\
.681 \\
.809 \\
.448 \\
.393\end{array}$ & $\begin{array}{l}.527 \\
.433 \\
.466 \\
.473 \\
.309 \\
.276\end{array}$ \\
\hline $\begin{array}{l}29 \\
30 \\
31 \\
32 \\
33 \\
34\end{array}$ & 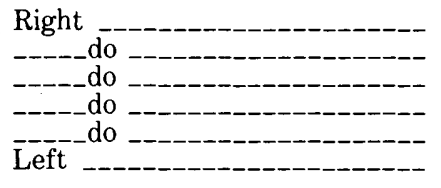 & $\begin{array}{l}.715 \\
.739 \\
.631 \\
.672 \\
.739 \\
.618\end{array}$ & $\begin{array}{l}.457 \\
.490 \\
.411 \\
.415 \\
.499 \\
.407\end{array}$ \\
\hline $\begin{array}{l}35 \\
36 \\
37 \\
38 \\
39 \\
40\end{array}$ & 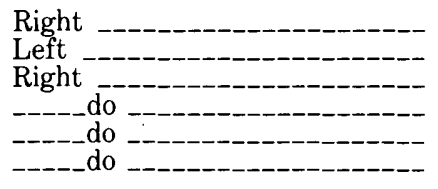 & $\begin{array}{l}.739 \\
.706 \\
.502 \\
.764 \\
.696 \\
.664\end{array}$ & $\begin{array}{l}.498 \\
.465 \\
.299 \\
.473 \\
.457 \\
.415\end{array}$ \\
\hline $\begin{array}{l}41 \\
42 \\
43 \\
44 \\
45 \\
46\end{array}$ & 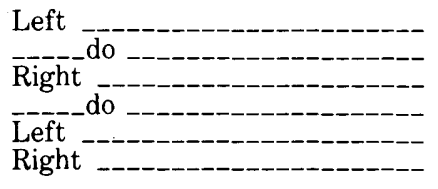 & $\begin{array}{l}.813 \\
.830 \\
.764 \\
.695 \\
.724 \\
.390\end{array}$ & $\begin{array}{l}.527 \\
.598 \\
.564 \\
.473 \\
.473 \\
.261\end{array}$ \\
\hline $\begin{array}{l}47 \\
48 \\
49 \\
50 \\
51 \\
52\end{array}$ & 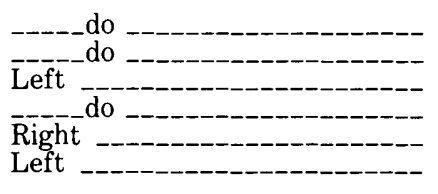 & $\begin{array}{l}.427 \\
.436 \\
.375 \\
.399 \\
.384 \\
.386\end{array}$ & $\begin{array}{l}.299 \\
.291 \\
.249 \\
.291 \\
.270 \\
.257\end{array}$ \\
\hline $\begin{array}{l}53 \\
54 \\
55 \\
56 \\
57 \\
58\end{array}$ & 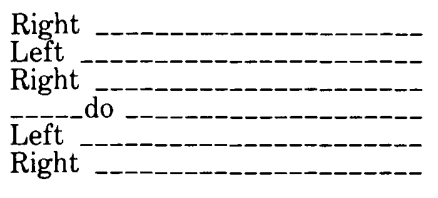 & $\begin{array}{l}.398 \\
.390 \\
.366 \\
.399 \\
.365 \\
.342\end{array}$ & $\begin{array}{l}.266 \\
.257 \\
.249 \\
.273 \\
.262 \\
.259\end{array}$ \\
\hline $\begin{array}{l}59 \\
60 \\
61 \\
62 \\
63 \\
64\end{array}$ & 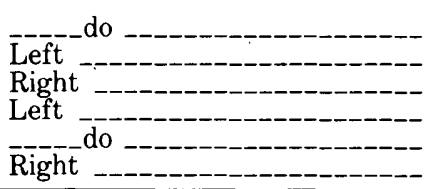 & $\begin{array}{l}.382 \\
.390 \\
.390 \\
.333 \\
.416 \\
.415\end{array}$ & $\begin{array}{l}.249 \\
.274 \\
.249 \\
.249 \\
.274 \\
.276\end{array}$ \\
\hline
\end{tabular}




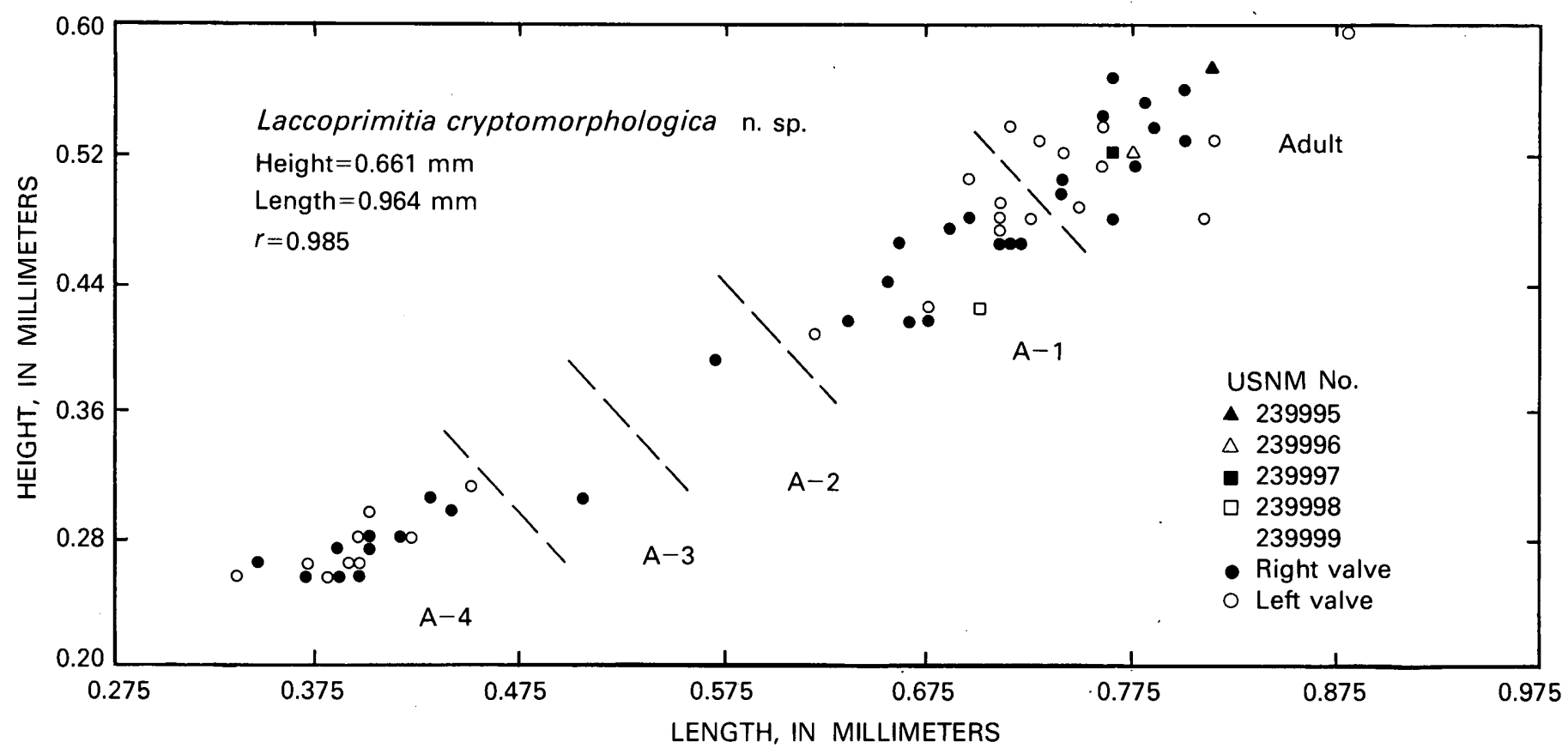

FIGURE 20. -Size-dispersion diagram for 64 specimens of Laccoprimitia cryptomorphologica from the Millersburg Member of the Lexington Limestone at Sadieville. All specimens are from USGS 7455-CO.

TABLE 23.-Statistical summary of measurements (in $\mathrm{mm}$ ) for Laccoprimitia cryptomorphologica from USGS colln. No. 7455-CO

\begin{tabular}{|c|c|c|c|c|c|c|c|}
\hline \multirow{2}{*}{ Instar } & \multirow{2}{*}{$\begin{array}{c}\text { No. of } \\
\text { specimens }\end{array}$} & \multicolumn{3}{|c|}{ Length } & \multicolumn{3}{|c|}{ Height } \\
\hline & & Mean & Minimum & Maximum & Mean & Minimum & Maximum \\
\hline Adult_ & 22 & 0.773 & 0.726 & 0.880 & 0.523 & 0.473 & 0.598 \\
\hline A-1 & 19 & .686 & .618 & .723 & .453 & .407 & .498 \\
\hline A-2 & 1 & .569 & ---- & ----- & .390 & ----- & -..- \\
\hline$A-3$ & 1 & .502 & $-\ldots$ & -..- & .299 & -.-- & ---- \\
\hline$A-4$ & 21 & .392 & .333 & .448 & .269 & .249 & .309 \\
\hline
\end{tabular}

Growth is curvilinear, height $=0.661$, length $=0.964$, and the data points correlate well with the equation $r=0.985$.

Discussion. - The surface relief of Laccoprimitia cryptomorphologica is so subdued and poorly defined that at first glance the species appears almost like a Schmidtella except for the diagnostic marginal rim. Of other species of Laccoprimitia, it most closely resembles $L$. rudis (Ulrich, 1890), but it differs in having an even more obscure development of typical Laccoprimitia morphology than does $L$. rudis. In general, L. cryptomorphologica appears nearly smooth, whereas $L$. rudis does not.

Initially, the large hump on some of the specimens formed by the posterior part of the umbo was regarded as a possible dimorphic feature, as suggested by Levinson $(1951$, p. 559). However, further examination of $L$. cryptomorphologica indicated a gradation from specimens having a large hump to those having a smaller one, even in juvenile specimens. Consequently, this character is not considered to be dimorphic.

The shell surface of specimens of $L$. cryptomor- phologica is generally corroded, which makes it difficult to determine the original ornamentation. Three specimens, one adult (USNM 239997, pl. 14, fig. 27) and two A-1 instars, have two subparallel horizontal grooves on the anterocentral part of the valves; these are probably artifacts of preservation.

The specific name is from the Greek "kryptos," meaning "hidden," in reference to the obscure morphology of the lateral surface of the valve.

Types. - Holotype, USNM 239995, an adult right valve from USGS colln. 7455-CO, Lexington Limestone, Millersburg Member, $22 \mathrm{ft}$ above the base of Sadieville section C. Figured paratypes, USNM 239996-239998, USNM 271064, 271065; unfigured paratypes $(60$ measured specimens on one slide) USNM 239999, from USGS colln. 7455-CO.

Occurrence.-Laccoprimitia cryptomorphologica occurs in the Millersburg Member of the Lexington Limestone and in the Clays Ferry Formation, both of Edenian Age, but has not as yet been found in any other stratigraphic units. A total of 357 specimens has been recovered from the following two USGS localities and eight collections: Dry Fork Road, 7039-CO (4), 7043-CO (6), 7046-CO (1); Sadieville C, 7454-CO (111), 7455-CO (183), 7456-CO (36), 7459-CO (10), 7471-CO (6).

\section{Laccoprimitia claysferryensis $n$. sp.}

Plate 13, figures 7, 8; plate 14, figures 28-32

Diagnosis. - Sulcus narrow but well defined, adductorial node and velar bend distinct. Velar bend delimited on domicilial side by distinct groove, bend may be wide 
and inflated, with reduced or absent subvelar channel. Surface of larger valves may be sparsely pitted, especially on velar bend.

Description.-Lateral outline nearly amplete and subovate. Greatest height posterior of midlength and greatest length just ventral of midheight. Greatest width posterodorsal. Dorsal margin umbonate, concealing slightly incised straight hingeline. Ventral margin broadly convex, grading into sharply curved anterior and broadly curved posterior margins. Cardinal angles obtuse, poorly defined. Umbo divided into two lobes by S2; posterior lobe wider and extends higher above hingeline than does anterior. S2 anterior of midlength, sharply defined, narrow, extends approximately 40 percent of distance from umbo to ventral margin and bifurcates ventrally to surround large, well-defined subcentral adductorial node. Velar bend inflated, wide, ridgelike, distinctly separated from lateral valve surface by narrow groove that extends from anterior to posterior cardinal angles. Marginal rim extends beyond velar bend in lateral view. Poorly defined channel may be present between ventral border of velar bend and marginal rim, or velar bend may be inflated so channel is absent. Valve surface, including velar bend, has widely spaced pits. Hingement and internal morphology not seen.

Measurements. - All specimens are calcareous valves embedded in limestone chips; consequently, precise measurements are not possible. However, approximate measurements of the length and height of the holotype and three paratypes are given in table 24 .

Discussion.-Laccoprimitia claysferryensis differs from other species of Laccoprimitia by the inflated velar bend distinctly set off from the lateral surface of the valve by a narrow groove. This character may superficially resemble the grooves made by retention of molts in Conchoprimitia Opik, 1935, as discussed by Henningsmoen (1953a, p. 252-253) and Jaanusson (1957, p. 416-417). However, there is no evidence for retention of molts in L. claysferryensis, and because other species of Laccoprimitia have similar but less well defined grooves, this feature is considered to be an extreme development of a character common in Laccoprimitia. The inflated velar bend is more conspicuous in larger specimens; in smaller specimens (pl. 14, fig. 30), the velar bend tends to be more like a ridge or flange. Whether this extreme inflation represents some form of sexual dimorphism or is an ontogenetic change is not possible to determine because only seven specimens of this species have been found.

The specific name of the species refers to its occurrence in the Clays Ferry Formation at Clays Ferry, Ky.

Types. - Holotype, USNM 240006, a left valve from the Clays Ferry Formation, $8 \mathrm{ft}$ above the contact with

\begin{tabular}{|c|c|c|c|c|c|}
\hline & Type & $\begin{array}{l}\text { USNM } \\
\text { No. }\end{array}$ & $\begin{array}{c}\text { USGS } \\
\text { colln. No. }\end{array}$ & Length & Height \\
\hline 1 & Holotype & 240006 & D1169-CO & 0.681 & 0.415 \\
\hline 2 & Figured paratype & 240007 & D1171-CO & .573 & .332 \\
\hline 3 & - & 240008 & D1170-CO & .515 & Not measurable. \\
\hline 4 & - do & 240009 & D1170-CO & .647 & .440 \\
\hline
\end{tabular}

the Tanglewood Limestone Member of the Lexington Limestone, Clays Ferry Type Section, Supplement, USGS colln. D1169-CO, Madison County, Ky. Paratypes, USNM 240007-240009, 271066.

Occurrence.-This species occurs in the lower Clays Ferry Formation (Edenian) at the supplemental type section. Seven specimens have been found in the following three USGS collections: D1169-CO (1), D1170-CO (4), D1171-CO (2). It has not as yet been found elsewhere.

\section{Genus MILLERATIA Swartz, 1936}

Type species.-Beyrichia cincinnatiensis Miller, 1875.

Milleratia perminima (Ulrich, 1890)

Plate 14, figures 1-5

1890. Primitia perminima Ulrich, p. 131, pl. 7, fig. 7 .

1934. Primitia perminima Ulrich. Bassler and Kellett, p. 452 (see for other references).

Diagnosis. - Small, subovate, sulcus ending in distinct pit, no adductorial node.

Description. - Lateral outline subovate, amplete, ventral margin smoothly curved, anterior and posterior margins more sharply curved, dorsal margin slightly sinuous. Hinge incised, cardinal angle obtuse. Sulcus narrow, ending in deep pit slightly above midlength. Valves inflated, marginal rim very narrow, velar bend inflated and rounded. Shell surface smooth.

Measurements. - According to Berdan's measurements, the syntypes (USNM 41436) are $0.325 \mathrm{~mm}$ long and $0.225 \mathrm{~mm}$ high, and $0.337 \mathrm{~mm}$ long and $0.225 \mathrm{~mm}$ high, respectively. A figured hypotype (USNM 271056) is $0.350 \mathrm{~mm}$ long and $0.250 \mathrm{~mm}$ high.

Discussion.-This small species is assigned to Milleratia because of its distinct sulcus ending in a deep pit. Although Ulrich $(1890$, p. 131) stated that it occurs with Laccoprimitia centralis (Ulrich, 1890), M. perminima is not considered a juvenile of that species because immature instars of Laccoprimitia have the adductorial node and weak sulcus characteristic of adults, and where the ontogeny is known, as in L. cryptomorphologica $\mathrm{n}$. sp., these features are even less well developed in juveniles. Because of its small size, M. perminima might be a juvenile of some larger species of Milleratia, but as yet no larger species has been found associated with it. Provisionally, therefore, the syntypes 
and hypotypes of Milleratia perminima are considered as adult specimens.

Although Bassler and Kellett (1934, p. 452) cited USNM 41436 as belonging to the holotype, this number refers to two specimens, neither of which can be certainly identified with Ulrich's original figure (Ulrich, 1890, pl. 7, fig. 7). These specimens are here considered syntypes.

Types.-Syntypes, two left valves, USNM 41436; hypotypes, USNM $271056-271058$.

Occurrence.-The syntypes are labelled as coming from "Trenton gr., Mouth of Licking River, Covington, Ky.," although Ulrich (1890, p. 131) described them as coming from the "Utica horizon." Additional specimens, one of which is figured here (USNM 271056, pl. 14, fig. 3 ), have been found in the matrix of the type lot of Ceratopsis intermedia Ulrich, 1894 (USNM 41500), from Bank Lick Creek near Covington, Ky. Both these localities are believed to represent the Point Pleasant Tongue of the Clays Ferry Formation. Milleratia perminima (USNM 271057, 271058, pl. 14, figs. 4, 5) also has been found in the lower part of the Point Pleasant Tongue (Shermanian) in the Moffett Road section, USGS colln. 8406-CO, in the De Mossville Quadrangle, Kentucky.

\section{Genus UNINODOBOLBA n. gen.}

Type species. - Uninodobolba franklinensis $\mathrm{n}$. $\mathrm{sp}$.

Species included. - Only the type species.

Diagnosis. - Subrectangular, trilobate, low but distinct L2 and S2 ending in and surrounding an adductorial node. Velar structure only obscure velar bend.

Discussion. - The adductorial node in S2 suggests a relationship of this genus with Laccoprimitia Ulrich and Bassler, 1923, but Laccoprimitia is nonlobate or bilobate and lacks the S1 of Uninodobolba. Both genera are similar in having an obscure velar bend above a thin marginal rim.

The generic name refers to the single L2 and the generally bulbous nature of the valve.

Geologic range. - As yet, this genus is known only from the lower Upper Ordovician (Edenian) of central Kentucky.

\section{Uninodobolba franklinensis $n$. sp. Plate 14, figures $37-41$}

Diagnosis. - S1 shallow, L2 small, rounded, S2 extending from dorsum to about midheight of valve, there dividing around small adductorial node, L3 inflated dorsally at about midlength of valve. Surface finely reticulate.

Description.-Lateral outline amplete, subrectangular, greatest length just ventral of midheight and greatest height just anterior of midlength. Anterior margin more sharply rounded than posterior, ventral margin very gently curved. Dorsal margin sinuous, posterior part of hingeline incised. Cardinal angles obtuse and subequal; anterior cardinal angle less well defined and greater than posterior. Hinge straight and approximately 68 percent of greatest length. L1 fairly narrow, merges with anterior margin and protrudes slightly above hingeline in lateral view. S1 short, shallow and poorly defined, merges dorsally with S2. L2 short, subcircular, does not reach dorsal margin. S2 extends less than half height of valve, bifurcates ventrally to surround adductorial node. L3 broad, more than half length of valve, inflated in its anterodorsal part, merges with posterior margin. All lobes are confluent ventrally. Narrow rim apparently present around free margin, velar bend on ventral and posterior margins. Entire surface, except for adductorial node, finely reticulate. Dimorphism and hingement not observed.

Measurements. -The holotype, a left valve (USNM 240037), is $0.747 \mathrm{~mm}$ long and $0.465 \mathrm{~mm}$ high. A paratype left valve (USNM 271070) is $0.525 \mathrm{~mm}$ long and $0.325 \mathrm{~mm}$ high; a paratype right valve (USNM 271071 ) is $0.550 \mathrm{~mm}$ long and $0.325 \mathrm{~mm}$ high.

Discussion. - Although only two left valves and one right valve of this species have been found, the combination of an adductorial node in S2 and a well-defined L2 is not, so far as we know, present in any other genus or species.

Black and Cuppels (1973, p. C2) noted that the Strodes Creek Member of the Lexington Limestone was similar lithologically to the Devils Hollow Member, which is lower in the section. The occurrence of the holotype of Uninodobolba franklinensis in the Devils Hollow and the two paratypes in the Strodes Creek suggests that this species may be facies controlled.

The specific name is based upon the occurrence of the holotype in Franklin County, Ky.

Types. - Holotype, a left valve in limestone from the Devils Hollow Member of the Lexington Limestone, USNM 240037; paratypes, USNM 271070, 271071 from the Strodes Creek Member of the Lexington Limestone.

Occurrence-Lexington Limestone, Devils Hollow Member (Edenian), Frankfort East A section, USGS colln. D1207-CO, Franklin County, Ky.; Lexington Limestone, Strodes Creek Member (Edenian), Winchester reference section B, USGS colln. 7318-CO, Clark County, Ky.

\section{Genus ECTOPRIMITIA BOUČEK, 1936}

Type species-Primitia corrugata Krause, 1892.

Ectoprimitia? sp. cf. E.? diminucarina Kraft, 1962

Plate 14, figures $34-36$

Description.-Lateral outline amplete, subrectangular, anterior margin smoothly curved, ventral margin straight to very slightly concave, posterior 
margin curved dorsally to straight dorsal margin. Hingeline approximately 84 percent of greatest length. Anterior cardinal angle more obtuse than posterior cardinal angle. Sulcus extends from dorsum to midpoint of valve, curves anteriorly to outline indistinct node. Possible trace of narrow velar frill around anterior part of free margin. Ornamentation not known.

Measurements. - The figured right valve is $0.519 \mathrm{~mm}$ long and $0.291 \mathrm{~mm}$ high.

Discussion. - This form is represented by only three specimens, one of which, USNM 240024 (pl. 14, figs. 34, 36 ), is a corroded right valve and another, USNM 271069 (pl. 14, fig. 35) is a left valve. The third is a phosphatic internal mold. The right valve is similar in outline and sulcation to the specimen of E.? diminucarina illustrated by Kraft (1962, pl. 5, figs. 15a-c, pl. 6, figs. 1-5), but its cardinal angles are not as acuminate, and because of poor preservation, the presence of a velar frill cannot be determined certainly.

Types.-Figured specimens, USNM 240024, 271069.

Occurrence. - The right valve is from the Strodes Creek Member (Edenian) of the Lexington Limestone at the Kentucky Route 89 locality, USGS colln. 7312-CO. The left valve is from the Devils Hollow Member (Edenian) of the Lexington Limestone at the Frankfort East A locality, USGS colln. D1207-CO. The internal mold is from the Grier Limestone Member (Shermanian) of the Lexington Limestone at the Switzer A locality, USGS colln. D1115-CO.

\section{Ectoprimitia? sp. \\ Plate 14, figure 33}

Description.-Lateral outline amplete; hingeline straight, cardinal angles distinct, anterior and posterior margins equally curved, ventral margin gently curved. Unisulcate, sulcus at midlength, extends from dorsum to about midheight of valve and curves anteriorly around low node. Central part of valve surface flattened, slightly inflated posteriorly. Narrow marginal rim widest at anterior cardinal angle, apparently obsolete ventrally. Valve surface finely pitted.

Measurements. - The left valve is $0.575 \mathrm{~mm}$ long and $0.387 \mathrm{~mm}$ high.

Discussion. - This single left valve is relatively shorter than is typical of Ectoprimitia Bouček, 1936, and has a less well developed marginal rim; hence, it is only questionably assigned to the genus. It differs from $E c$ toprimitia sp. cf. E. diminucarina Kraft, 1962, in being shorter, in being inflated posteriorly, and in having the central part of the valve flattened.

Types. - Figured specimen USNM 271068.

Occurrence.-The only specimen was found in the lowest foot of the Curdsville Limestone Member
(Kirkfieldian) of the Lexington Limestone, Tyrone $\mathrm{C}$ section, USGS colln. 5083-CO.

\section{Genus NINGULELLA n. gen.}

Type species. -Ningulella paupera $\mathrm{n}$. sp.

Species included.-?Primitia matutina Jones and Holl, 1865.

?Primitiella paucisulcata Burr and Swain, 1965.

Primitiella? indifferenta Schallreuter, 1968.

Diagnosis. - Lateral outline subovate, amplete to slightly postplete, hingeline long and straight, cardinal angles obtuse. Valves nearly equal; right overlaps left around posterior and ventral margins, both meet equally at anterior margin. No marginal structures, no sulci, valves smoothly curved. No dimorphism observed.

Discussion.-This featureless genus resembles Primitiella Ulrich, 1894, but lacks the incipient stragular process, marginal structures, and anterior recessed area described for Primitiella by Guber and Jaanusson (1964). In addition, in Primitiella, the left valve overlaps the right, whereas in Ningulella the right valve is larger. The right-over-left overlap of Ningulella suggests a relationship with Pinnatulites Hessland, 1949, which also has a similar lateral outline, but unlike Ningulella, Pinnatulites is characterized by an angular cross section or a flattened posterior area. Ningulella is superficially similar to Elliptocyprites Swain, 1962, but as noted by Swain (1962, p. 741, 742), Elliptocyprites has a sinuous ventral overlap like that of some podocopids; also, the cardinal angles of Elliptocyprites are more obtuse than are those of Ningulella.

Primitia matutina Jones and Holl, 1865, and Primitiella paucisulcata Burr and Swain, 1965, are questionably assigned to Ningulella because of the similarity in lateral outline and convexity, but as details of the overlap and margin are not described for these species, the assignment cannot be confirmed until the types are restudied.

The name of this new genus is derived from the Latin "ningulus," meaning "nobody," and the diminutive suffix- "ella," and refers to the lack of distinctive characters in the genus.

Geologic range-Middle(?) and Upper Ordovician (Shermanian to Edenian) of the central United States, and possibly lower Upper Ordovician (Caradocian) of England and Estonia.

\section{Ningulella paupera n. sp. \\ Plate 15, figures $10-18$}

Diagnosis. - Valves thickened around anterior margin, shell surface smooth. 
Description. - Lateral outline amplete to slightly postplete; anterior margin smoothly curved; ventral margin gently curved to straight; posterior margin gently curved in ventral part, more steeply curved dorsally. Hinge line straight, long, about 66 percent of maximum length, very slightly incised. Cardinal angles obtuse, anterior more obtuse than posterior. Greatest length at or slightly above midheight, greatest height at about midlength, greatest width slightly posterior of midlength. Both valves slightly thickened anteriorly so that they meet nearly perpendicularly to the contact margin. Left valve smaller than right, with fine, hairline groove outlining narrow anteroventral rim. Groove may extend to posterior part of valve. Shell surface smooth, nonsulcate. Hingement, muscle scar, and dimorphism not observed.

Measurements. - The holotype carapace is $1.150 \mathrm{~mm}$ long, $0.515 \mathrm{~mm}$ high, and $0.505 \mathrm{~mm}$ wide. The largest paratype carapace (USNM 240043) is $1.288 \mathrm{~mm}$ long, $0.701 \mathrm{~mm}$ high, and $0.510 \mathrm{~mm}$ wide. Fragmentary specimens suggest that the species may reach somewhat larger dimensions.

Discussion.-This species is somewhat similar to Ningulella? paucisulcata (Burr and Swain, 1965) from the Maquoketa Shale of Iowa but has a straighter ventral margin and a less smoothly rounded posterior margin. As noted under the generic disucssion, N.? paucisulcata is only questionably assigned to Ningulella because the type of overlap and marginal characters were not described, although the illustrations (Burr and Swain, 1965, pl. 2, figs. 3, 10) suggest that the right valve may overlap the left. As yet, no certain juvenile specimens of Ningulella paupera have been found, so the ontogeny of the species is unknown.

Types. - Holotype, a carapace from the Strodes Creek Member of the Lexington Limestone, USNM 271078, USGS colln. 7318-CO. Paratypes, both carapaces, USNM 240043, USNM 271077, also from the Strodes Creek.

Occurrence-Ningulella paupera has been found questionably in the Grier Limestone Member (Shermanian) and in the Millersburg and Strodes Creek Members (Edenian) of the Lexington Limestone and Clays Ferry Formation. A total of 23 specimens has been recovered from the following five USGS localities and six collections: Hunters Ferry Road, 4191-CO (1?); Dry Fork Road, 7041-CO (2), 7055-CO (7); Winchester Reference Section B, 7318-CO (9); U.S. Highway 227, 7325-CO (2); Sadieville Section C, 7468-CO (2).

\section{Ningulella sp. \\ Plate 15, figures 1-9}

Description.-Lateral outline amplete, subrectangular; anterodorsal half of anterior margin nearly straight, anteroventral half smoothly curved; ventral margin very gently curved to straight, subparallel to dorsal margin; posterior margin smoothly curved; dorsal margin long and straight. Cardinal angles obtuse, anterior more obtuse than posterior. Hingeline straight, about 70 percent of greatest length. Greatest length and greatest height both pass about through midpoint of valve. Central part of valves nearly flat, curving steeply to anterior and posterior margins, and gently to dorsal and ventral margins. Posterior part of valve curves more sharply to contact margin than anterior and has a low node near midheight. No marginal rim. Shell surface smooth.

Measurements. - The figured specimen USNM, 240044 is $0.769 \mathrm{~mm}$ long and $0.412 \mathrm{~mm}$ high.

Discussion.-This form is similar to Ningulella paupera $\mathrm{n}$. sp. in general outline and shape of the valves but differs from that species in the presence of a low posterior node on both valves. This node is suggestive of Pseudoprimitiella Warshauer, 1981, but is less well developed, and the marginal rim described by Warshauer (1981) for Pseudoprimitiella is lacking in this taxon. Only four left and two right valves have been found, and all these are smaller than the specimens assigned to $N$. paupera; these valves might, therefore, represent an immature form of that species. Until more and better preserved specimens, including carapaces, are found, we consider it better to leave this form in open taxonomy. These valves are somewhat similar to specimens referred to Primitiella unicornis (Ulrich, 1879) by Burr and Swain (1965, p. 22), but the Maquoketa specimens are apparently punctate and have a more distinct dorsal sag that do the Lexington specimens.

Types.-Figured specimens USNM 240044, 271072-271076.

Occurrence.-Five of the six valves are from the Logana Member of the Lexington Limestone, Frankfort East A section, USGS colln. D1196-CO. One right valve is from the Grier Limestone Member of the Lexington, Valley View C locality, USGS colln. 4876-CO. The range of this taxon is Kirkfieldian to Shermanian in age.

\section{Genus PSEUDOPRIMITIELLA Warshauer, 1981}

Type species. -Leperditia unicornis Ulrich, 1879.

$$
\text { Pseudoprimitiella? sp. }
$$

Plate 15, figures 19,20

Description.-Lateral outline amplete to slightly postplete; anterodorsal part of anterior margin nearly straight, anteroventral part smoothly curved; ventral margin gently curved, subparallel to hingeline; posterior margin smoothly curved; dorsal margin straight, hingeline about 70 percent of greatest length. Greatest 
length and greatest height pass through midpoint of valve, greatest width in anterodorsal quarter. Anterodorsal part of valve inflated, inflation extending as low swelling parallel to and below hingeline to posterior part of valve, ending in small, sharp, posteriorly directed spine, which projects over posterior margin and is situated below midheight. Surface ornamentation not known.

Measurements. - The figured specimen is $0.959 \mathrm{~mm}$ long and $0.492 \mathrm{~mm}$ high.

Discussion. - This single corroded left valve is only questionably assigned to Pseudoprimitiella because it lacks the marginal rim of that genus, although this lack may be due to poor preservation. The anterior inflation is like that of Pseudoprimitiella, but the posterior extension of it below and parallel to the hingeline is unlike the described species such as $P$. unicornis (Ulrich, 1879) and $P$. huilensis (Copeland, 1970), both of which species have a more or less well-defined median sulcus extending ventrally from the dorsum.

Types.-Figured specimen, USNM 240021.

Occurrence. - The single left valve is from the Clays Ferry Formation (Edenian), Sadieville C locality, USGS colln. 7471-CO.

\section{Family LOMATOPISTHIIDAE Guber and Jaanusson, 1964}

Genus BOLBOPISTHIA Guber and Jaanusson, 1964

Type species-Thomasatia carinata Kraft, 1962.

\author{
Bolbopisthia sculptilis (Ulrich, 1890) \\ Plate 16 , figures $1,3-8$
}

1890. Primitia? sculptilis Ulrich, p. 136-137, pl. 8, fig. 6; p. 185. 1894. Halliella sculptilis (Ulrich). Ulrich, p. 656.

1915. Halliella sculptilis (Ulrich). Bassler, p. 578.

1934. Halliella sculptilis (Ulrich). Bassler and Kellett, p. 322-323.

Diagnosis. - Carinal ridge extending from anterodorsal quarter of valve to midlength, or anterior to midlength, of L3. Surface of valve coarsely reticulate except for velar flange, carinal ridge, S2, and dorsal part of valve adjacent to S2 and L2.

Description.-Lateral outline slightly postplete; anterior margin smoothly curved, ventral margin nearly straight to slightly concave, posterior margin broadly curved, dorsal margin sinuous. Hingeline straight, incised where L3 overreaches it. L1 narrow, merges above midheight into carinal ridge; L2 small, knoblike; L3 broad, inflated, occupies more than posterior half of valve. S1 short, shallow, distinct only in dorsal half of valve; S2 long, deep, extends nearly to carinal ridge. Carinal ridge rounded in cross section, extends from anterodorsal quarter of valve parallel to free margin to a point ventral of $\mathrm{S} 2$, where it curves dorsally and ends near midlength but below midheight of L3. Carinal ridge may end in blunt knob. Velar flange extends from anterior to posterior cardinal angle, broadest posteroventrally. Surface coarsely reticulate except for velar flange, carinal ridge, S2, and part of valve dorsal to S2 and L2. Dimorphism, overlap, and hingement not observed.

Measurements. - The holotype is too poorly preserved to measure. The largest figured hypotype (USNM 240022 ) is $2.149 \mathrm{~mm}$ long and $1.284 \mathrm{~mm}$ high.

Discussion.-The holotype (USNM 41362, pl. 16, fig. 1) of Bolbopisthia sculptilis (Ulrich, 1890) is a partly exfoliated right valve, which is incomplete posteriorly. However, although the carinal ridge has been exfoliated, its location can be seen on the subinternal mold, and coarse reticulation is visible on the few remaining parts of the external shell. The lobation and general outline of the holotype also agree with our specimens. In addition, Ulrich (1890, p. 137) described his species as coming from "the dark Upper Trenton limestone at Perryville, Boyle County, Ky." and Bassler (1915, p. 578) revised the horizon to "Trenton (Perryville)." All four of our specimens come from the Perryville Limestone Member of the Lexington Limestone, and three of them come from the vicinity of Perryville, Ky. Consequently, we feel relatively confident that our specimens are correctly assigned to $B$. sculptilis in spite of the poor preservation of the holotype of that species. The lobation and carinal ridge are typical of the lomatopisthiid genus Bolbopisthia Guber and Jaanusson, 1964, although lomatopisthiid dimorphism has not been observed in the small number of specimens at hand. One specimen (USNM 271079, pl. 16, fig. 3) is less coarsely reticulate than the others and might be considered a representative of another species; however, this apparent difference is believed to have been caused by heavier silicification.

This species most closely resembles Bolbopisthia reticulata (Kirk, 1928), which, according to Kirk (1928, p. 410), was found in the Catheys Limestone at Nashville, Tenn. Although the holotype (YPM 26820; pl. 16 , fig. 2) is not complete, $B$. reticulata appears to have a wider carinal ridge and finer reticulation than does $B$. sculptilis. Study of additional material of both species will be necessary to determine whether or not these species are synonymous.

Ulrich (1890, p. 136) originally described $B$. sculptilis as Primitia? sculptilis, and later, in the second part of the same paper, (Ulrich, 1891, p. 185) transferred this species to his new genus Halliella. Bassler (1915, p. 577), Bassler and Kellett (1934, p. 322), and Shimer and Shrock (1944, p. 665) all cited this species as the type species of the genus Halliella Ulrich, 1890. However, Miller (1892, p. 707) had already designated Halliella retifera Ulrich, 1890, as the type species of Halliella; $H$. retifera was also given as the type by Ulrich and Bassler 
(1923, p. 300), Warthin (1948, p. 646), Moore and others (1961, p. Q114), and Pokorný (1965, p. 154). As Ulrich did not designate a type species for Halliella in 1890, Miller's subsequent designation is valid.

Types. - Holotype, USNM 41362; figured hypotypes, USNM 240022, 271079-271081.

Occurrence.-The four hypotypes are all from the Salvisa Bed of the Perryville Limestone Member (Shermanian) of the Lexington Limestone and came from the following localities: Bryantsville B, USGS colln. 6137-CO (2); Perryville North, USGS colln. 6915-CO (1); Perryville South, USGS colln. 5051-CO (1).

Suborder ERIDOSTRACA Adamczak, 1961

Family ERIDOCONCHIDAE Henningsmoen, 1953

Genus AMERICONCHA Schallreuter, 1968

Type species. -Eridoconcha multiannulata Levinson, 1951 .

\section{Americoncha dubia n. sp.}

Plate 17, figures $13-29$

Diagnosis. - Umbo high, divided into two unequal nodes by shallow, short, slitlike sulcus restricted to apex of umbo. Distinct velar bend parallel to narrow free margin. One to rarely three lamellae present, distal edge of each lamella abuts against proximal side of velar bend of next larger lamella.

Description.-Lateral outline subelliptical; anterior margin more sharply curved than posterior margin, ventral margin gently curved, dorsal margin asymmetrically umbonate. Greatest height just posterior of sulcus, greatest length just ventral of midheight, and greatest width about at midpoint of carapace. Cardinal angles obtuse and poorly defined. Hingeline straight, approximately 58 percent of greatest length, concealed in lateral view by umbo. Prominent umbo divided into two unequal lobes by shallow narrow sulcus; posterior lobe higher and wider than anterior. Broad velar bend and narrow marginal rim present on each lamella, marginal rim of each lamella abuts against proximal side of velar bend of next larger lamella. Number of lamellae generally two, rarely three or one. Shell surface apparently smooth. Hingement appears to be simple.

Measurements.-The holotype (USNM 240038), a carapace, is $0.525 \mathrm{~mm}$ long, $0.375 \mathrm{~mm}$ high, and 0.325 $\mathrm{mm}$ wide. Measurements of 26 single valves are given in table 25.

Discussion.-Americoncha dubia n. sp. most closely resembles $A$. bifurcata (Copeland, 1965) from the Middle Ordovician Bucke Formation of Ontario. However, unlike $A$. dubia, $A$. bifurcata has a distinct node in the ventral part of the sulcus and also has a better developed velar bend. Both species have two lamellae; $A$. dubia may have only one or as many as three, but very few
TABLE 25. - Measurements (in $\mathrm{mm}$ ) of 26 specimens (USNM 240041) of Americoncha dubia from USGS colln. No. 7468-CO, from the Clays Ferry Formation

\begin{tabular}{|c|c|c|c|c|}
\hline & Valve & Length & Height & No. of retained instars \\
\hline 1 & Right & 0.522 & 0.340 & 2 \\
\hline 2 & -_-_do & .520 & .338 & 2 \\
\hline 3 & --_-_do _ & .611 & .351 & 2 \\
\hline 4 & - & .520 & .403 & 2 \\
\hline 5 & - & .416 & .286 & 2 \\
\hline 6 & - & .455 & .286 & 1 \\
\hline 7 & - do & .521 & .403 & 2 \\
\hline 8 & -----do _- & .468 & .351 & 2 \\
\hline 9 & Left & .299 & .208 & 1 \\
\hline 10 & --_do & .455 & .299 & 1 \\
\hline 11 & Right & .377 & .273 & 2 \\
\hline 12 & ---_-_do _----_- & .377 & .286 & 2 \\
\hline 13 & Left & .390 & .260 & 2 \\
\hline 14 & Right _--------- & .585 & .403 & 2 \\
\hline 15 & Left -.-.-..- & .312 & .195 & 1 \\
\hline 16 & _-do _-_-_-_- & .455 & .338 & 2 \\
\hline 17 & Right & .312 & .208 & 1 \\
\hline 18 & - & .377 & .260 & 2 \\
\hline 19 & Left & .390 & .234 & 1 \\
\hline 20 & Right & .481 & .364 & 2 \\
\hline 21 & Left & .390 & .273 & 2 \\
\hline 22 & Right & .299 & .208 & 2 \\
\hline 23 & - & .507 & .364 & 2 \\
\hline 24 & -----do _- & .260 & .169 & 1 \\
\hline 25 & Left & .403 & .260 & 1 \\
\hline 26 & Right _-_------- & .405 & .264 & 1 \\
\hline
\end{tabular}

specimens retaining three valves were recovered. Specimens with three lamellae are relatively much higher in relation to length and have a less conspicuous sulcus than specimens with two lamellae, because of the additional valve. Specimens with only two instars may retain either the adult and adult-1 or the adult-1 and the adult-2. This suggests that some mechanism operated during molting that tended to restrict the number of lamellae to two, the most recent instar and the one immediately preceding it, and that earlier instars were shucked off by the animal. Unilamellar valves of Americoncha dubia are very similar to specimens of Laccoprimitia, but the nodes on either side of the sulcus are more asymmetrical in Laccoprimitia species.

The occurrence of specimens of Americoncha dubia with two lamellae but of widely different sizes suggests that, within limits, the number of lamellae may be useful at least for the discrimination of species if not for genera, as proposed by Adamczak (1961) and Schallreuter (1968), in contradistinction to the views of Levinson (1951), Keenan (1951), and Jones (1962, 1968). Schallreuter (1968, p. 113), following Adamczak (1961, p. 80), considered the genus Eridoconcha Ulrich and Bassler, 1923, to have 7 to 11 lamellae and proposed his new genus Americoncha for species having 1 to 3 lamellae and two large nodes on either side of a short 
flat sulcus. However, the type species of Eridoconcha, E. rugosa Ulrich and Bassler, 1923, as represented by three syntype carapaces (USNM 82389, pl. 17, figs. 7-10) has only four lamellae and also has a short shallow sulcus on the umbo. Although this raises the question whether Americoncha is a distinct genus or a junior synonym of Eridoconcha, the holotype (USNM 116365, pl. 17, fig. 12) of A. multiannulata (Levinson, 1951), the type species of Americoncha, has but two lamellae, and is sufficiently different from $E$. rugosa that Americoncha is provisionally considered a valid genus. Keenan (1951, p. 564) considered Placentula marginata Ulrich, 1890 , a senior synonym of $E$. rugosa and therefore suggested that the type species of Eridoconcha should be $E$. marginata. This synonymy was questioned by Rome and Goreux (1960, p. 192), and examination of the holotype (USNM 41364, pl. 17, fig. 11) suggests that Schallreuter (1968, p. 113) was correct in assigning forms identified as Eridoconcha marginata to Americoncha.

The similarity of unilamellar specimens of Americoncha dubia to species of Laccoprimitia suggests a possible derivation from a common ancestor. Levinson (1951) and Keenan (1951). have previously noted the resemblance of species of Eridoconcha (some now included in Americoncha) to Milleratia Swartz, 1936; these genera and Laccoprimitia have in common an umbonate shell with the umbo either divided by a sulcus or having an internal sulcament in the position of the sulcus, and a velar bend proximal to and not obscuring a thin marginal ridge in lateral view. Schallreuter (1968, 114-116, fig. 1) has provided a phylogeny for the suborder Eridostraca of Adamczak (1961), in which he derives Eridoconcha from Americoncha, and both from an ancestor to Conchoprimites Hessland, 1949; in our view, a common ancestor with the LaccoprimitiaMilleratia line seems more probable. As noted under the discussion of that genus, Schmidtella s.s. lacks the characteristic sulcus or sulcament of the Eridoconchidae and the Cryptophyllidae and is therefore considered unlikely as a progenitor of either family, as has been proposed by other authors. However, the genus Easchmidtella Schallreuter, 1967, which has a sulcament, may prove to be related to Cryptophyllus Levinson, 1951.

Implicit in the above discussion is the conclusion that Americoncha, Eridoconcha, and similar forms are ostracodes that retain early molts rather than being conchostracans (see Schallreuter, 1977, for a list of authors with other views). Rome and Goreux (1960) and Schallreuter (1977) have both emphasized the importance of the discrete hinge of these forms in relating them to the ostracodes. In addition, their similarity to other unquestioned palaeocopes makes it difficult to con- sider them as belonging to any other group. The specific name indicates some doubt about the generic assignment.

Types. - Holotype, a carapace, USNM 240038, from the Clays Ferry Formation, USGS colln. 7468-CO; paratypes, USNM 240040, 24.0041, USNM 271083-271088, also from USGS colln. 7468-CO, USNM 240042, from the Millersburg Member of the Lexington Limestone, USGS colln. 7454-CO.

Occurrence.-Americoncha dubia has been found in the Millersburg and Tanglewood Limestone Members of the Lexington Limestone (Edenian) and in the Clays Ferry Formation (Edenian) at the Sadieville C locality. Fifty-one specimens were recovered from the following four USGS collections: 7454-CO (1), 7467-CO (2), 7468-CO (46), 7471-CO (2).

\section{Family CRYPTOPHYLLIDAE Adamczak, 1961 Genus CRYPTOPHYLLUS Levinson, 1951}

Type species.-Eridoconcha oboloides Ulrich and Bassler, 1923.

\author{
Cryptophyllus sp. \\ Plate 17, figures $4-6$
}

Description.-Lateral outline ovate; dorsal margin curved by umbo, anterior and posterior margins evenly curved, ventral margin very gently curved. End view cordiform, greatest width above midheight. Hinge about half greatest length, straight, incised between umbones. Each umbo divided by narrow, short, indistinct sulcus ending ventrally in obscure muscle spot. Narrow grooves, one on right valve and two on left, outline previous molt stages. Shell surface smooth.

Measurements. - The single carapace is $0.875 \mathrm{~mm}$ long, $0.612 \mathrm{~mm}$ high, and $0.475 \mathrm{~mm}$ wide.

Discussion. - Only one carapace of this taxon has been found, and the left valve of this specimen is partly obscured by sparry calcite. However, it shows the $V$-shaped grooves between the retained molts characteristic of Cryptophyllus Levinson, 1951. It differs from C. oboloides (Ulrich and Bassler, 1923) (this report, pl. 17, figs. 1-3), the type species of Cryptophyllus, in having fewer retained molt stages and in being more elongate. These features also distinguish it from most other Ordovician species of Cryptophyllus, but one specimen is inadequate to determine whether these characters are consistent and of specific value.

Types. - Figured specimen USNM 271082.

Occurrence. - The specimen is from the lowest foot of the Curdsville Limestone Member (Kirkfieldian) of the Lexington Limestone, Tyrone $\mathrm{C}$ section, USGS colln. 5083-CO. 


\author{
Order PODOCOPIDA Müller, 1884 \\ Suborder METACOPINA Sylvester-Bradley, 1961 \\ Superfamily HEALDIACEA Harlton, 1933 \\ Family BAIRDIOCYPRIDIDAE Shaver, 1961 \\ Genus PHELOBYTHOCYPRIS n. gen.
}

Type species.-Bythocypris cylindrica (Hall). Ulrich, 1894.

Species included.-Pontocypris? illinoisensis Ulrich, 1890.

Bythocypris? lindstroemii Jones, 1890.

Diagnosis.-Elongate, dorsum asymmetrically arched, venter straight or concave, posterior evenly rounded, anterior more sharply curved. Greatest width and height posterior. Valves nearly equal, left valve overlaps right around free margin, ventral contact nearly straight, left valve may overreach right dorsally. Hinge long, tongue and groove type in both valves, left valve appears to have two stop ridges on inner surface near ventral margin. Muscle scar weakly impressed or not visible. Shell thin, smooth.

Discussion.-That most smooth reniform Paleozoic ostracode species assigned to the Holocene genus Bythocypris Brady, 1880, lack the duplicature and muscle scars of that genus has been recognized for more than 20 years (Shaver, 1958); several genera have been erected to receive these species. Ulrich (1894; see 1897, p. 687) commented that many species assigned to Bythocypris by T. R. Jones were very similar externally to Cytherellina Jones and Holl, 1869, but he placed Leperditia (Isochilina) cylindrica Hall, 1871, here designated the type species of Phelobythocypris, in Bythocypris, although with reservations. More recent studies on Cytherellina by Becker $(1965$, p. 384, 385) and Berdan $(1972$, p. 39, 40) have shown a hinge structure similar to that of Phelobythocypris. However, Phelobythocypris lacks the internal calluses on either side of the muscle scar characteristic of Cytherellina and also has a thinner shell.

Although Phelobythocypris is most similar to Cytherellina and may have been ancestral to it, several other genera are superficially similar to Phelobythocypris. The genus Longiscula Neckaja, 1958, resembles it in lateral outline, as do some species that have been put in Healdianella Pozner, 1951, but in Longiscula, the right valve overreaches the left dorsally, and, according to Ellis and Messina's (1965, Suppl. 3) translation of Pozner, Healdianella has a well-developed muscle scar. The Ordovician genus Shenandoia Kraft, 1962, has a narrow anterodorsal gape which Kraft $(1962$, p. 73,74$)$ considered diagnostic and which is not present in Phelobythocypris. Parabairdiacypris Polenova, 1970 (=Silus Polenova, 1968 not Silus Gill, 1862) is also similar to Phelobythocypris in lateral outline, but in dorsal view the outline of Parabair. diacypris is evenly elliptical, without the pronounced posterior widening of Phelobythocypris.

The name Phelobythocypris is derived from the Greek "phelos," meaning "deceitful," combined with Bythocypris.

Geologic range. - Middle and Upper Ordovician (Chazyan (?) to Richmondian) of North America.

Phelobythocypris cylindrica (Hall, 1871)

Plate 18, figures $8-18$

1871. Leperditia (Isochilina) cylindrica Hall, p. 27, pl. 8, fig. 12, not Leperditia (Isochilina) cylindrica? (Hall). Jones, 1858, p. 253; not Leperditia cylindrica (Hall). Hall, 1859, p. 80; Jones, 1884 , p. 344; Bassler, 1915, p. 701; Bassler and Kellett, 1934, p. 383.

1872. Leperditia (Isochilina) cylindrica Hall. Hall, p. 231.

1874. Leperditia cylindrica Hall. Miller, p. 122.

1875. Leperditia cylindrica Hall. Miller, p. 351.

1875. Leperditia (Isochilina) cylindrica Hall. Hall and Whitfield, p. 101 , pl. 4, fig. 5 .

1879. Leperditia cylindrica Hall. Walcott, p. 23.

1879. Leperditia cylindrica Hall. Ulrich, p. 11.

1889. Bythocypris cylindrica (Hall). Ulrich, p. 48, pl. 9, fig. 6

1894. Bythocypris cylindrica (Hall). Ulrich, p. 687 , pl. 44, figs. 29-35. 1915. Bythocypris cylindrica (Hall). Bassler, p. 149.

1934. Bythocypris cylindrica (Hall). Bassler and Kellett, p. 226

1951. Bythocypris cylindrica (Hall). Keenan, p. 567, pl. 78, figs. 4, 8-13.

1965. Bythocypris? cylindrica (Hall). Copeland, p. 45, pl. 2, figs. 2-4. 1970. "Bythocypris" cylindrica (Hall). Copeland, p. 23, pl. 4, fig. 25. 1973. "Bythocypris" cylindrica (Hall). Copeland, p. 36, pl. 4, fig. 3. 1974. Bairdiocypris cylindrica (Hall). Copeland, p. 10, 46, pl. 6, fig. 7.

Diagnosis.-Greatest height in posterior third of valve, length approximately twice height. Dorsal margin with long, nearly straight slope from greatest height to anterior margin, ventral margin straight to slightly concave.

Description. - Lateral outline elongated subreniform; dorsal margin asymmetrically curved with short posterior slope and long anterior slope, anterior margin sharply curved, ventral margin sinuous, with greatest concavity at or slightly anterior to midlength, posterior margin broadly curved. Dorsal outline lachryform, greatest width in posterior third. Cross section subovate. Valves nearly equal, left valve overlaps right around free margin with long narrow lappet along ventral margin at greatest concavity. Hinge long, straight to very slightly curved, consists of grooves on anterodorsal parts of both valves. Muscle scar and marginal structures not seen. Shell surface smooth.

Measurements. - The dimensions of eight hypotypes (USNM 41795) from the upper third of the Kope Formation at Cincinnati, Ohio, are given in table 26. The measurements are probably not entirely accurate because although an effort was made to select undistorted carapaces, some may be slightly crushed or sheared; the width, in particular, is suspect. The measurements of two hypotypes, from the Tanglewood 
TABLE 26.-Measurements (in $\mathrm{mm}$ ) of eight specimens of Phelobythocypris cylindrica (USNM 41795), Kope Formation, Cincinnati, Ohio

[Type: hypotype]

\begin{tabular}{rrr}
\hline Length & Height & Width \\
\hline 1.300 & 0.650 & 0.400 \\
.975 & .500 & .375 \\
1.275 & .650 & .425 \\
1.062 & .550 & .425 \\
1.025 & .550 & .425 \\
1.175 & .600 & .450 \\
1.062 & .550 & .425 \\
1.150 & .600 & .400 \\
\hline
\end{tabular}

Limestone Member of the Lexington Limestone, USGS colln 7467-CO, are as follows: USNM 240031, length $1.046 \mathrm{~mm}$, height $0.566 \mathrm{~mm}$; USNM 240032, length $0.836 \mathrm{~mm}$, height $0.455 \mathrm{~mm}$.

Discussion.-The types of Leperditia (Isochilina) cylindrica Hall, 1871, have not been seen by us; according to Hall and Whitfield $(1875$, p. 101) they were returned to C. B. Dyer. Consequently, the preceding diagnosis and description are based on specimens identified as hypotypes (USNM 41795) of Bythocypris cylindrica (Hall) by Ulrich (1894; see 1897, p. 687, 688, pl. 44, figs. 29-33) and supplemented by observations on specimens from the Lexington Limestone and the Clays Ferry Formation. Ulrich (1894; see 1897, p. 687, 688) described a thickening of the shell on the interior of valves of Phelobythocypris cylindrica, which he compared with the two low swellings or ridges of Cytherellina siliqua (Jones, 1855). Of the 16 hypotypes under USNM 41795, only one is a single valve; because that specimen is filled with matrix, the presence of the thickening cannot be confirmed. Two other specimens may have been present originally, as there are two gaps in the rows of specimens, one of which might have been the single valve illustrated by Ulrich (1894; see 1897, pl. 44 , fig. 32). No distinct internal swellings have been seen on the specimens of $P$. cylindrica from the Lexington Limestone and the Clays Ferry Formation.

Ulrich (1894; see 1897, p. 688) commented that “* * * of all the Cincinnati Ostracoda, B. cylindrica is by far the most abundant." Phelobythocypris cylindrica is also common in the Lexington Limestone and Clays Ferry Formation; however, many of the specimens are poorly preserved. The outline may be distorted by crushing or shearing of the carapace and the surface may be damaged by recrystallization, or the specimens may be phosphatic molds. In general, smaller specimens appear to be less inflated posteriorly and to have a shorter hinge than larger specimens; whether this represents a change during ontogeny or whether more than one species is represented is not certain. Because of the possibility that the group of specimens from the
Lexington Limestone and Clays Ferry Formation here assigned to $P$. cylindrica may not be conspecific, no attempt was made to provide measurements for population studies.

As indicated in the synonymy, in the last half of the 19th century, two unrelated taxa were cited in the literature as Leperditia (Isochilina) cylindrica Hall or Leperditia cylindrica Hall. Hall (1852, p. 14, pl. 4, figs. 8a, b) described as Cytherina cylindrica a leperditicopid from the Silurian "Medina Formation" of New York, which Jones (1858, p. 253) changed to Leperditia (Isochilina) cylindrica. Later, Hall (1871, p. 27) applied the name Leperditia (Isochilina) cylindrica to a new species of podocopid ostracode from the Ordovician of Ohio. This confusing homonymy was resolved by Ulrich in 1894 (1897), when he transferred Leperditia (Isochilina) cylindrica Hall, 1871, to Bythocypris.

Types.-Figured hypotypes, USNM 41795, 240031, 271091-271096; unfigured hypotype 240032.

Occurrence. -Phelobythocypris cylindrica occurs both in the Clays Ferry Formation (Edenian) and in the Lexington Limestone (Curdsville, Grier, Perryville, Tanglewood, Devils Hollow, Millersburg, and Strodes Creek, Kirkfieldian to Edenian). A total of 2,552 specimens was recovered from the following 17 USGS localities and 58 collections: Perryville South, 5015-CO (30); Keene A, 5022-CO (2); Tyrone C, 5083-CO (1); Devils Hollow Road, 5093-CO (1); Y.M.C.A. Camp, 5096-CO (1); Sadieville A, 5183-CO (4); Nicholasville 1, 5899-CO (2); Ford-Boonesboro Road, 6945-CO (49); Dry Fork Road, 7039-CO (129), 7040-CO (28), 7041-CO (180), 7043-CO, (153), 7045-CO (5), 7046-CO (32), 7047-CO (212), 7050-CO (90), 7053-CO (91), 7054-CO (47), 7055-CO (183), 7056-CO (15), 7059-CO (33), 7060-CO (21), 7061-CO (39), 7062-CO (12), 7068-CO (33), 7071-CO (15), 7072-CO (4), 7079-CO (44); Kentucky Route 89, 7312-CO (30); Winchester Reference Section B, 7318-CO (27); U.S. Route 227, 7325-CO (19); Sadieville C, 7450-CO (1), 7452-CO (1), 7454-CO (232), 7455-CO (153), 7456-CO (59), 7457-CO (9), 7458-CO (5), 7459-CO (2), 7460-CO (1), 7461-CO (20), 7462-CO (56), 7467-CO (33), 7468-CO (111), 7471-CO (144), 7472-CO (6), 7475-CO (1), 7477-CO (24), 7478-CO (14); Switzer A, D1115-CO (56), D1117-CO (52), D1132-CO (26); Clays Ferry Type Section, supplement, D1170-CO (3), D1171-CO (3); Frankfort East A, D1207-CO (1); Gratz A, D1301-CO (4), D1309-CO (2), D1310-CO (1).

This species has been reported from Middle and Upper Ordovician rocks throughout North America (Copeland, 1970).

Genus SHENANDOIA Kraft, 1962

Type species. - Shenandoia acuminulata Kraft, 1962. 


\section{Shenandoia? sp. \\ Plate 18, figures 1-4}

Description. - Lateral outline subovate, dorsal margin slightly curved, anterior margin sharply rounded, ventral margin straight, posterior margin bluntly angulate to rounded. Dorsal margin almost parallel to ventral margin. Left valve overlaps right on free margins, overreaches right slightly on dorsal margin, overlap greatest on ventral and posterior margins. Hinge weakly incised, ventral contact margin slightly sinuous. Shell surface smooth.

Measurements. - The largest figured specimen (USNM 271090 ) is $0.800 \mathrm{~mm}$ long, $0.400 \mathrm{~mm}$ high, and $0.400 \mathrm{~mm}$ wide. A smaller specimen (USNM 271089) is $0.700 \mathrm{~mm}$ long, $0.350 \mathrm{~mm}$ high, and $0.325 \mathrm{~mm}$ wide.

Discussion. - This form is characterized by its weakly incised hinge and bluntly angular posterior margin. The posterior angulation is on the larger left valve; the right valve is rounded posteriorly. The specimens are only questionably assigned to Shenandoia Kraft, 1962, because they appear to lack the characteristic anterodorsal gape, or incisure, of that genus. However, this apparent lack may be due to the type of preservation of the Kentucky material, as all specimens are calcitic rather than silicified like the types of Shenandoia.

Types. - Figured specimens USNM 271089, 271090.

Occurrence.-Seven specimens were found in the Strodes Creek Member (Edenian) of the Lexington Limestone at the Kentucky Route 89 locality, USGS colln. 7312-CO, Winchester Quadrangle, Clark County, $\mathrm{Ky}$.

Genus ELLIPTOCYPRITES Swain, 1962

Type species. - Elliptocyprites parallela Swain, 1962.

\section{Elliptocyprites sp.}

Plate 18, figures 5-7

Description. - Lateral outline elliptical, dorsal margin straight to slightly convex, subparallel to ventral margin, anterior and posterior margins nearly equally curved, ventral margin straight to slightly concave. Carapace elongate, left valve slightly overlaps right around free margin, valves meet evenly at hingeline. Slight ventral lappet on left valve at concavity of ventral margin. Greatest height and width slightly postmedian. Dorsal outline elongate elliptical, anterior more sharply curved than posterior. Cross section rounded elliptical. Shell surface smooth. Internal structures not seen.

Measurements. - Complete carapace (USNM 240034) $1.012 \mathrm{~mm}$ long, $0.475 \mathrm{~mm}$ high, and $0.412 \mathrm{~mm}$ wide. A single left(?) valve (USNM 240033) is $1.000 \mathrm{~mm}$ long and $0.425 \mathrm{~mm}$ high.
Discussion. -This form is similar to Elliptocyprites longula Swain, 1962, but is relatively longer and the dorsal margin is more curved. It also resembles the specimen illustrated by Copeland (1970, p. 26, pl. 5, fig. 21) as "Bythocypris" lindstroemi? Jones, 1890, but has more evenly rounded ends. Unfortunately, although about 40 specimens can be assigned to this taxon on the basis of their lateral outline, only one is sufficiently well preserved to show the character of the overlap and the dorsum; most are either badly corroded or steinkerns. Without more data on possible specific variation, we consider it undesirable to give this taxon a formal name.

Types.-Figured specimens USNM 240033 and 240034 from the Strodes Creek Member of the Lexington Limestone.

Occurrence.-Elliptocyprites sp. occurs in both the Clays Ferry Formation (Edenian) and the Lexington Limestone (Curdsville, Grier, Millersburg, and Strodes Creek, Kirkfieldian to Edenian). A total of 40 specimens was found at the following 6 USGS localities and in 8 collections: Keene A, 5022-CO (1); Dry Fork Road, 7053-CO (26), 7055-CO (4), 7056-CO (2); Kentucky Route 89, 7312-CO (2); Winchester Reference Section B, 7318-CO (2); Sadieville C, 7471-CO (1); Switzer A, D1115-CO (2).

\section{Family RISHONIDAE Sohn, 1960} Genus SILENIS Neckaja, 1958

Type species. -Silenis subtriangulatus Neckaja, 1958.

\section{Silenis kentuckyensis $\mathbf{n}$. sp.}

Plate 18, figures 19-25

Diagnosis.-Valves distinctly asymmetrical, right valve with subangular centrodorsal inflation.

Description. - Lateral outline elongate subtriangular, valves subequal in size. Dorsal margin convex, anterior margin bluntly curved, ventral margin straight to slightly concave, posterior margin more sharply curved than anterior. Left valve overlaps right around anterior, ventral and posterior margins; right valve overreaches left along short straight hingeline. Greatest height at midlength, greatest length halfway between midheight and ventral margin, greatest width in centrodorsal part of carapace. Dorsal part of right valve has subangular inflation which forms flattened dorsum; left valve gently and evenly rounded. Valve surface smooth. Hingement and musculature not seen.

Measurements. - The holotype (USNM 240056) is $0.975 \mathrm{~mm}$ long, $0.475 \mathrm{~mm}$ high, and $0.375 \mathrm{~mm}$ wide. The figured paratype (USNM 240057) is $1.075 \mathrm{~mm}$ long, $0.500 \mathrm{~mm}$ high, and $0.450 \mathrm{~mm}$ wide.

Discussion. - This species differs from others assigned to the genus in having the inflated centrodorsal area on the right valve which produces a flattened dorsum. Most 
other species of Silenis Neckaja, 1958, are Silurian in age; however, S. kentuckyensis appears to have the diagnostic characters of the genus. The specific name is based on its occurrence in Kentucky.

Types.-Holotype, USNM 240056, a complete carapace from the Strodes Creek Member of the Lexington Limestone, Winchester Reference Section B, 10 $\mathrm{ft}$ above the base of the section; USGS colln. 7318-CO. Figured paratype, USNM 240057, a complete carapace from the same collection.

Occurrence.-Only three specimens of this species have been found; two as indicated above, from the Strodes Creek Member (Edenian) of the Lexington Limestone, Winchester Reference Section B, USGS colln. 7318-CO. Another poorly preserved carapace was found in a tongue of the Clays Ferry Formation at the nearby Dry Fork Road section, USGS colln. 7043-CO. This species is not known to occur elsewhere.

Family KRAUSELLIDAE Berdan, 1961

Genus KRAUSELLA Ulrich, 1894

Type species. -Krausella inaequalis Ulrich, 1894.

Krausella sp.

Plate 19, figures $12-17$

Description.-Lateral outline subelliptical, dorsal margin straight, anterior margin broadly curved, ventral margin straight to slightly convex, posterior margin more broadly curved than anterior. Left valve overlaps right around free margins with long ventral lappet. Hingeline long, straight, very slightly incised. Left valve broken posteriorly, may have been slightly acuminate, right valve has small posterior spine base just below midheight. Shell surface smooth.

Measurements. - The figured specimen (USNM 240014 ) is $1.483 \mathrm{~mm}$ long and $0.734 \mathrm{~mm}$ high.

Discussion. - This single, partly exfoliated carapace most closely resembles Krausella brevicornis (Keenan, 1951), but the spine appears to be relatively smaller and the hinge is not as deeply incised. It is very like the specimen of $K$. brevicornis illustrated by Copeland (1970, p. 28, pl. 5, fig. 28) from the Upper Ordovician Vaureal Formation of Quebec, but other specimens of $K$. brevicornis figured by Copeland $(1965$, p. $46-47$, pl. 2, figs. 10-12) from the Middle Ordovician of Ontario are wider and have a longer posterior spine on the right valve. As noted by Copeland (1977b, p. 45), the spine of the type species of Krausella, $K$. inaequalis Ulrich, 1894 , is a prolongation of the right valve; possibly species having hollow peglike spines set anteriorly from the posterior margin should be placed in another genus.

Types. - Figured specimen USNM 240014.

Occurrence.-The only specimen was found in the Strodes Creek Member (Edenian) of the Lexington
Limestone at Winchester Reference Section B, USGS colln. 7312-CO.

Genus PSEUDORAYELLA Neckaja, 1960

Type species.-Pseudorayella scala Neckaja, 1960.

Pseudorayella sp. aff. P. ovalis Neckaja, 1960

Plate 19, figures 6-11

Description.-Lateral outline sublanceolate, dorsal margin broadly curved, anterior margin more sharply curved, ventral margin straight to slightly concave, posterior margin of both valves acuminate. Left valve larger than right; overlaps it around free margins with distinct ventral lappet. Valves meet nearly equally at short hingeline, which is only slightly incised. Greatest length slightly below midheight, greatest height and width about at midlength. Posterior point on both valves below midheight. Width and height nearly equal but width slightly greater than height; cross section subcircular. Shell surface smooth.

Measurements. - Figured specimen (USNM 240058) is $1.300 \mathrm{~mm}$ long, $0.625 \mathrm{~mm}$ high, and $0.650 \mathrm{~mm}$ wide. Another figured carapace (USNM 271097) is $1.325 \mathrm{~mm}$ long, $0.675 \mathrm{~mm}$ high, and $0.700 \mathrm{~mm}$ wide. A small right valve is $0.650 \mathrm{~mm}$ long and $0.325 \mathrm{~mm}$ high.

Discussion. - This form is close to Pseudorayella ovalis Neckaja, 1960, from the Middle Ordovician of the Russian platform, but according to Neckaja (1960, p. 362), $P$. ovalis is smaller and the right valve slightly overreaches the left dorsally. The Lexington material is not adequate to determine whether the right valve overreaches the left, so whether these specimens represent $P$. ovalis or a new species is not certain. Species of Pseudorayella are superficially similar to Pseudobythocypris Shaver, 1958, but are more acuminate posteriorly and do not appear to have the muscle scar and marginal structures described for Pseudobythocypris by Shaver (1958).

Types. - Figured specimens USNM 240058, 271097.

Occurrence. - Two carapaces and six single valves in limestone were recovered from the Strodes Creek Member (Edenian) of the Lexington Limestone, to which this taxon is as yet restricted. The specimens were found in three USGS collections from three closely associated localities: Kentucky Route 89, 7312-CO (1); Winchester Reference Section B, 7318-CO (2); U.S. Route 227, 7325-CO (5).

\section{Family BAIRDIOCYPRIDAE Shaver, 1961} Genus REVERSOCYPRIS Pribyl, 1955

Type species.-Reversocypris regularis Pribyl, 1955.

Reversocypris? sp.

Plate 19, figures 1-5 
Description.-Lateral outline oval, dorsal margin gently curved, anterior and posterior margins equally and more sharply curved, ventral margin gently curved. Right? valve overreaches left? valve dorsally, left? valve overlaps right? ventrally, both valves meet equally at anterior and posterior margins. Hingeline slightly incised. Shell surface smooth. Greatest length, height, and width median.

Measurements. - The figured specimen (USNM 240023 ) is $0.614 \mathrm{~mm}$ long and $0.357 \mathrm{~mm}$ high.

Discussion.-Only two carapaces were found, which are questionably referable to this taxon, one of which is broken and may not belong with the other specimen. The remaining specimen is fairly well preserved and is described above. This carapace is so symmetrical in outline that the determination of the anterior and the posterior ends cannot be made with certainty. It most closely resembles Daliella caleyi Copeland, 1973, but is more elongate than the specimen figured by Copeland (1973, p. 25, pl. 4, figs. 6, 7); whether or not this difference is significant cannot be determined without additional material. The specimen is also similar to Bythocypris obliquedorsata Hessland, 1949, but differs in having a distinctly incised hingeline. It is questionably assigned to Reversocypris Pribyl, 1955, because of the reversal of overlap.

Types. - Figured specimen USNM 240023.

Occurrence.-Both specimens are from the Strodes Creek Member (Edenian) of the Lexington Limestone at the U.S. Route 227 locality, USGS colln. 7325-CO.

\section{REFERENCES CITED}

Abushik, A. F., 1971, Ostrakod'i opornogo razreza Silura-Nizhnego Devona Podolii, in Ivanova, V. A., ed., Paleozoyskiye ostrakody iz opornykh razrezov Yevropeyskoy chasti SSSR: Moscow, Izdatelstvo "Nauka," p. 7-133, 46 pls.

Adamczak, Franciszek, 1961, Eridostraca-A new suborder of ostracods and its phylogenetic significance: Acta Palaeontologica Polonica, v. 6, no. 1, p. 29-102, 4 pls.

Bassler, R. S., 1915, Bibliographic index of American Ordovician and Silurian fossils: U.S. National Museum Bulletin 92, 2 v.: 1,521 p. 1927, Ostracoda, in Twenhofel, W. H., Geology of Anticosti Island: Canada Geological Survey Memoir 154, p. 340-350. 1932, The stratigraphy of the central basin of Tennessee: Tennessee Division of Geology Bulletin 38, 268 p., 4 figs., 49 pls.

Bassler, R. S., and Kellett, Betty, 1934, Bibliographic index of Paleozoic Ostracoda: Geological Society of America Special Paper 1, 500 p., 24 figs.

Becker, Gerhard, 1965, Podocopida (Ostracoda) aus dem Mitteldevon der Sötenicher Mulde (N-Eifel): Senckenbergiana Lethaea, v. 46, no. 4/6, p. 367-441.

Benson, R. H., 1970, Architectural solutions to stress in rigid-frame micro-organisms: Third Annual Stereoscan Colloquium Proceedings, v. 3, p. 71-78, 13 figs.

1975, Morphologic stability in Ostracoda, in Swain, F. M., ed., Biology and paleobiology of Ostracoda - A Symposium: Bulletins of American Paleontology, v. 65 , p. 13-46.
Berdan, J. M., 1970, Ostracodes from the Lexington Limestone in Kentucky [abs.]: Geological Society of America Abstracts with Programs, v. 2, no. 3, p. 195.

1972, Brachiopoda and Ostracoda of the Cobleskill Limestone (Upper Silurian) of central New York: U.S. Geological Survey Professional Paper 730, 47 p., 6 pls.

Black, D. F. B., Cressman, E. R., and MacQuown, W. C., Jr., 1965, The Lexington Limestone (Middle Ordovician) of central Kentucky: U.S. Geological Survey Bulletin 1224-C, 29 p.

Black, D. F. B. , and Cuppels, N. P., 1973, Strodes Creek Member (Upper Ordovician)-A new map unit in the Lexington Limestone of north-central Kentucky: U.S. Geological Survey Bulletin $1372-\mathrm{C}, 16 \mathrm{p}$.

Bolton, T. E., 1966, Calatogue of type invertebrate fossils of the Geological Survey of Canada, v. 3: Ottawa, Geological Survey of Canada, $203 \mathrm{p}$

Bonham-Carter, G. F., 1967, FORTRAN IV program for Q-mode cluster analysis of nonquantitative data using IBM 7090/7094 computers: Kansas Geological Survey Computer Contribution 17, 28 p.

Bonnema, J. H., 1909, Beitrag zur Kenntnis der Ostrakoden der Kuckersschen Schicht $\left(C_{1}\right)$ : Groningen Universität, MineralogischGeologisches Institut Mitteilungen, v. 2, no. 1, 84 p.

Bray, J. R., and Curtis, J. T., 1957, An ordination of the upland forest communities of southern Wisconsin: Ecological Monographs, v. 27, no. 4 , p. $325-349$

Burr, J. H., Jr., and Swain, F. M., 1965, Ostracoda of the Dubuque and Maquoketa Formations of Minnesota and northern Iowa: Minnesota Geological Survey Special Publication Ser. SP-3, 40 p., 6 pls.

Butts, Charles, 1926, Geology of Alabama; The Paleozoic rocks: Alabama Geological Survey Special Report 14, p. 41-230, 4 figs., $74 \mathrm{pls}$.

Buzas, M. A., and Gibson, T. C., 1969, Species diversity-Benthonic Foraminifera in western North Atlantic: Science, v. 163, no. 3682, p. $72-73$.

Cooper, G. A., 1956, Chazyan and related brachiopods: Smithsonian Miscellaneous Collections, v. 127, pt. 1, text, p. 1-1024; pt. 2, plates, p. 1025-1045, 269 pls.

Copeland, M. J., 1965, Ordovician Ostracoda from Lake Timiskaming, Ontario: Canada Geological Survey Bulletin 127, 52 p., 11 pls. 1970, Ostracoda from the Vauréal Formation (Upper Ordovician) of Anticosti Island, Quebec: Canada Geological Survey Bulletin 187, p. 15-29, 2 pls.

-1971, Ostracoda, in Steele, H. M., and others, A Middle Ordovician fauna from Braeside, Ottawa Valley, Ontario: Canada Geological Survey Bulletin 211, p. 42, 1 pl.

1973, Ostracoda from the Ellis Bay Formation (Ordovician), Anticosti Island, Quebec: Canada Geological Survey Paper 72-43, 49 p., 9 pls.

1974, Middle Ordovician Ostracoda from southwestern District of Mackenzie: Canada Geological Survey Bulletin 244, 55 p., 9 pls.

1977a, Ordovician Ostracoda, southeastern District of Franklin: Canada Geological Survey Bulletin 269, p. 77-96, 6 pls.

1977b, Early Paleozoic Ostracoda from southwestern District of Mackenzie and Yukon Territory: Canada Geological Survey Bulletin 275, 88 p., 16 pls.

Copeland, M. J., and Bolton, T. E., 1977, Additional paleontological observations bearing on the age of the Lourdes Formation (Ordovician), Port au Port Peninsula, western Newfoundland: Canada Geological Survey Paper 77-1B, p. 1-13, 3 pls.

Cressman, E. R., 1973, Lithostratigraphy and depositional environments of the Lexington Limestone (Ordovician) of central Kentucky: U.S. Geological Survey Professional Paper 768, 61 p., 11 pls. 
Donahue, Jack, and Rollins, H. B., 1974, Paleoecological anatomy of a Conemaugh (Pennsylvanian) marine event, in Briggs, Garrett, ed., Carboniferous of the southeastern United States: Geological Society of America Special Paper 148, p. 153-170.

Drake, R. T., 1940, Revision of the genus Schmidtella [abs.]: Missouri Academy of Science Proceedings, v. 5, no. 4, p. 132.

Ellis, B. F., and Messina, A. R., 1965, Catalogue of Ostracoda; Supplement 3: New York, American Museum of Natural History, [no consecutive pagination].

Emmons, Ebenezer, 1855, American geology, containing a statement of the principles of the science with full illustrations of the characteristic American fossils: Albany, N.Y., v. 1, pt. 2, 251 p.

Farris, J. S., 1969, On the cophenetic correlation coefficient: Systematic Zoology, v. 18, p. 279-285.

Foerste, A. F., 1924, Upper Ordovician faunas of Ontario and Quebec: Canada Geological Survey Memoir 138, 255 p., 14 figs., 46 pls.

Gevirtz, J. L., Park, R. A., and Friedman, G. M., 1971, Paraecology of benthonic Foraminifera and associated micro-organisms of the continental shelf off Long Island, New York: Journal of Paleontology, v. 45, no. 2, p. 153-177.

Gibbons, A. B., 1973, Geologic map of parts of Newport and Withamsville quadrangles, Campbell and Kenton Counties, Kentucky: U.S. Geological Survey Geologic Quadrangle Map GQ-1072.

Grabau, A. W., and Shimer, H. W., 1909, North American index fossils; Invertebrates: New York, v. 1, 853 p. [1910].

Guber, A. L., 1963, Some Richmond Ostracoda from Indiana and Ohio: Urbana, University of Illinois, Ph.D. thesis. (Abstract in Dissertation Abstracts, v. 23, no. 8, p. 2873-2874.)

1968, Bollia Jones and Holl, 1886 (Ostracoda)-Designation of a type-species under the plenary powers. Z. N. (S.) 1831: Bulletin of Zoological Nomenclature, v. 24, pt. 6, p. 360-363.

Guber, A. L., and Jaanusson, Valdar, 1964, Ordovician ostracodes with posterior domiciliar dimorphism: Uppsala University, Geological Institutions Bulletin, v. 43, no. 2, 41 p., 6 pls

Hall, James, 1852, Palaeontology of New-York; v. 2, Containing descriptions of the organic remains of the lower middle division of the New-York System: Albany, N.Y., 362 p., 85 pls.

1859, Catalogue of the species of fossils described in volumes 1 , 2 , and 3 of the "Palaeontology of New-York"; with corrections in nomenclature as far as determined at the present time: New York State Cabinet of Natural History, Annual Report 12, p. 63-96.

1871, Description of new species of fossils from the Hudson River group of Ohio and Trenton limestones of Wisconsin: Albany, N.Y., Argus Co., advance sheet, p. 21-28, 2 pls.

1872 , Description of new species of fossils from the Hudson River group, in the vicinity of Cincinnati, Ohio: New York State Museum of Natural History Annual Report 24, p. 225-232, 2 pls.

Hall, James, and Whitfield, R. P., 1875, Descriptions of invertebrate fossils, mainly from the Silurian System: Ohio Geological Survey Report, v. 2, Geology and Palaeontology, pt. 2, Palaeontology, p. 65-161, 9 pls. [Table of contents gives title as: Descriptions of Silurian fossils.]

Harris, R. W., 1957, Ostracoda of the Simpson Group of Oklahoma: Oklahoma Geological Survey Bulletin 75, 333 p., 10 pls.

Hazel, J. E., 1970, Binary coefficients and clustering in biostratigraphy: Geological Society of America Bulletin, v. 81, no. 11, p. $3237-3252$.

-1971, Ostracode biostratigraphy of the Yorktown Formation (upper Miocene and lower Pliocene) of Virginia and North Carolina: U.S. Geological Survey Professional Paper 704, 13 p.

1977, Use of certain multivariate and other techniques in assemblage zonal biostratigraphy - Examples utilizing Cambrian, Cretaceous, and Tertiary benthic invertebrates, in Kauffman, E. G., and Hazel, J. E., eds., Concepts and methods of biostratigraphy: Stroudsburg, Pa., Dowden, Hutchinson \& Ross, p. 187-212.

Henningsmoen, Gunnar, 1953a, Classification of Paleozoic straighthinged ostracods: Norsk geologisk tidsskrift, v. 31 , p. 185-288, 2 pls.

-1953b, The Middle Ordovician of the Oslo region, Norway; 4 Ostracoda: Norsk geologisk tidsskrift, v. 32 , no. 1, p. 35-56, 5 pls. 1954, Upper Ordovician ostracods from the Oslo region, Norway: Norsk geologisk tidsskrift, v. 33 , nos. 1-2, p. 69-105, 8 pls.

1965, On certain features of palaeocope ostracodes: Geologiska Föreningens i Stockholm Förhandlingar, v. 86, p. 329-394.

Hessland, Ivar, 1949, Investigations of the Lower Ordovician of the Siljan District, Sweden; I. Lower Ordovician ostracods of the Siljan District, Sweden: Uppsala University, Geological Institutions Bulletin, v. 33, p. 97-394, 26 pls.

Jaanusson, Valdar, 1957, Middle Ordovician ostracodes of central and southern Sweden: Uppsala University, Geological Institutions Bulletin, v. 37, pt. 3-4, p. $173-442,15$ pls.

1967, Ordovician ostracodes with supravelar antra: Uppsala University Geological Institutions Bulletin, v. 43, no. 7, 28 p., 3 pls. Johnson, R. G., 1970, Variations in diversity within benthic marine communities: American Naturalist, v. 104, no. 937, p. 285-300.

Jones, P. J., 1962, The ostracod genus Cryptophyllus in the Upper Devonian and Carboniferous of Western Australia: Australia Bureau of Mineral Resources, Geology and Geophysics, Bulletin $62-3,37$ p., 3 pls.

1968, Upper Devonian Ostracoda and Eridostraca from the Bonaparte Gulf basin, northwestern Australia: Australia, Bureau of Mineral Resources, Geology and Geophysics, Bulletin 99, 96 p., 7 pls.

Jones, T. R., 1858, Notes on the Palaeozoic bivalved Entomostraca; No. 4, Some North American species: Annals and Magazine of Natural History, ser. 3, v. 1, p. 241-257, 2 pls.

1884, Notes on the Palaeozoic bivalved Entomostraca; No. 17, Some North American Leperditiae and allied forms: Annals and Magazine of Natural History, ser. 5, v. 14, p. 339-347.

1890, On some Palaeozoic Ostracoda from North America, Wales, and Ireland: Geological Society of London Quarterly Journal, v. 46, p. $1-31,4$ pls.

1891, On some Ostracoda from the Cambro-Silurian, Silurian, and Devonian rocks: Canada Geological and Natural History Survey, Contributions to Canadian Micro-Palaeontology, pt. 3, p. $59-99,13$ pls.

1893, On some Palaeozoic Ostracoda from Westmoreland: Geological Society of London, Quarterly Journal, v. 49, p. 288-295, 1 pl.

1895, Notes on the Palaeozoic bivalved Entomostraca; No. 31, Some Devonian species: Annals and Magazine of Natural History, ser. 6 , v. 15 , p. 59-67, 1 pl.

Kaesler, R. L., 1966, Quantitative re-evaluation of ecology and distribution of Recent Foraminifera and Ostracoda of Todas Santos Bay, Baja California, Mexico: Kansas University Paleontological Contributions, Paper 10, $50 \mathrm{p}$.

Kay, G. M., 1934, Mohawkian Ostracoda; species common to Trenton faunules from the Hull and Decorah Formations: Journal of Paleontology, v. 8 , no. 3 , p. $328-343,1$ fig., 3 pls.

1940, Ordovician Mohawkian Ostracoda; lower Trenton Decorah fauna: Journal of Paleontology, v. 14, no. 3, p. 234-269, 6 pls.

Keenan, J. E., 1951, Ostracodes from the Maquoketa shale of Missouri: Journal of Paleontology, v. 25, no. 5, p. 561-574, 2 pls.

Kesling, R. V., 1951, Terminology of ostracod carapaces: Michigan University, Museum of Paleontology Contributions, v. 9, no. 4, p. 93-171, 18 pls. 
Kesling, R. V., 1960a, Middle Ordovician Black River ostracods from Michigan; Part 2, Levisulculus and Eurychilina: Michigan University, Museum of Paleontology Contributions, v. 15, no. 15, p. 349-363, $4 \mathrm{pls}$.

1960b, Middle Ordovician Black River ostracods from Michigan; Part 3, Platybolbina: Michigan University, Museum of Paleontology Contributions, v. 15 , no. 16 , p. $365-385,8$ pls.

Kesling, R. V., Crafts, F. S., Darby, D. G., Shubak, K. E., and Smith, R. N., 1960, Middle Ordovician Black River ostracods from Michigan; Introduction and Part 1, The nature of Macronotella: Michigan University, Museum of Paleontology Contributions, v. 15 , no. 13 , p. 293-314, 3 pls.

Kesling, R. V., Hall, D. D., and Melik, J. C., 1962, Middle Ordovician Black River ostracods from Michigan; Part 4, Species of Colacchilina (new genus), Laccochilina, and Hesperidella: Michigan University, Museum of Paleontology Contributions, v. 17, no. 8, p. 205-213, 2 pls.

Kesling, R. V., and Hussey, R. C., 1953, A new family and genus of ostracod from the Ordovician Bill's Creek shale of Michigan: Michigan University, Museum of Paleontology Contributions, v. 11 , no. 4 , p. $77-95,2$ pls.

Kilenyi, T. I., 1972, Transient and balanced genetic polymorphism as an explanation of variable noding in the ostracode Cyprideis torosa: Micropaleontology, v. 18, no. 1, p. 47-63, 1 pl.

Kirk, S. R., 1928, Ostracoda from the Trenton Limestone of Nashville, Tennessee: American Journal of Science, 5th series, v. 16, no. 95, p. 410-422, 1 fig.

Kraft, J. C., 1962, Morphologic and systematic relationships of some Middle Ordovician Ostracoda: Geological Society of America Memoir 86, 104 p. 19 pls.

Krandievsky, V. S., 1963, Fauna ostrakod Siluriiskikh vidkladiv Podillya: Kiev, Akademiya Nauk Ukraïnskoi RSR, Institut Geologichnikh Nauk, 148 p., 12 pls.

Levinson, S. A., 1951, Thin sections of Paleozoic Ostracoda and their bearing on taxonomy and morphology: Journal of Paleontology, $v$. 25 , no. 5 , p. $553-560,1 \mathrm{pl}$.

1968, Eoaquapulex, new name for Diplopsis Levinson, 1961: Micropaleontology, v. 14, no. 2, p. 248.

Luft, S. J., 1971, Geologic map of part of the Covington Quadrangle, northern Kentucky: U.S. Geological Survey Geologic Quadrangle Map GQ-955.

MacDonald, K. B., 1975, Quantitative community analysis: Recurrent group and cluster techniques applied to the fauna of the Upper Devonian Sonyea Group, New York: Journal of Geology, v. 83, no. 4 , p. $473-500$.

Maddocks, R. F., 1966, Distribution patterns of living and subfossil podocopid ostracodes in the Nosy Bé area, northern Madagascar: Kansas University Paleontological Institute, Paleontological Contributions, Paper 12, 72 p.

Martinsson, Anders, 1960, The primitiopsid ostracodes from the Ordovician of Oklahoma and the systematics of the family Primitiopsidae: Uppsala University, Geological Institutions Bulletin, v. 38, pt. 2, p. 139-154, 3 pls.

1962 , Ostracodes of the family Beyrichiidae from the Silurian of Gotland: Uppsala University, Geological Institutions Bulletin, v. $41,369 \mathrm{p}$.

Mello, J. F., and Buzas, M. A., 1968, An application of cluster analysis as a method of determining biofacies: Journal of Paleontology, v. 42 , no. 3 , p. $747-758$.

Melville, R. W., Secretary, International Commission on Zoological Nomenclature, 1970, Opinion 934-Bollia Jones and Holl, 1886 (Ostracoda): Designation of a type-species under the plenary powers: Bulletin of Zoological Nomenclature, v. 27, pts. 3/4, p. 169-170.
Miller, S. A., 1874a, Monograph of the Crustacea of the Cincinnati Group: Cincinnati Quarterly Journal of Science, v. 1, no. 2, p. 115-147.

1874b, Beyrichia Chambersi: Cincinnati Quarterly Journal of Science, v. 1, no. 3, p. 234.

1875, Some new species of fossils from the Cincinnati Group, and remarks upon some described forms: Cincinnati Quarterly Journal of Science, v. 2, no. 4, p. 349-355.

1892, North American geology and palaeontology for the use of amateurs, students, and scientists. First appendix, 1892: Cincinnati, Ohio, Western Methodist Book Concern, p. 665-718.

Moore, R. C., ed., 1961, Treatise on invertebrate paleontology. Part Q, Arthropoda 3: New York and Lawrence, Kansas, Geological Society of American and University of Kansas Press, $442 \mathrm{p}$.

Netskaya (Neckaja), A. I., 1960, Semeistvo Beecherellidae Ulrich, 1894, Rod Pseudorayella Neckaja gen. nov., in Novie vidy drevnikh rastenii i bespozvonochnykh SSSR, chast' 2: Moscow, Vsesoyuznyi Nauchno-Issledovatel'skii Geologicheskii Institut (VSEGEI), Ministerstva Geologii i Okhrany Nedr SSSR, p. $360-362,1$ pl.

1966, Ostrakody Ordovika i Silura SSSR: Vsesoyuznyi Neftyanoi Nauchno-Issledovatel'skii Geologo-Razvedochnyi Institut, Trudy, no. 251, 102 p., 12 pls.

1973, Ostrakody Ordovika i Silura SSSR: Vsesoyuznyi Neftyanoi Nauchno-Issledovatel'skii Geologo-Razvedochnyi Institut, Trudy, no. 324,88 p., 11 pls.

Öpik, A. A., 1937, Ostracoda from the Ordovician Uhaku and Kukruse Formations of Estonia: Tartu Ulikool Geoloogia-Instituudi Toimetused, no. 50,74 p., 15 pls.

Outerbridge, W. F., 1974a, Geologic map of the Paris West quadrangle, Bourbon and Fayette Counties, Kentucky: U.S. Geological Survey Geologic Quadrangle Map GQ-1162.

1974b, Geologic map of the Paris East quadrangle, Bourbon County, Kentucky: U.S. Geological Survey Geologic Quadrangle Map GQ-1167.

Park, R. A., 1968, Paleoecology of Venericardia sensu lato (Pelecypoda) in the Atlantic and Gulf Coastal Province-An application of paleosynecological methods: Journal of Paleontology, v. 42 , no. 4 , p. $955-986$.

1974, A multivariate analytical strategy for classifying paleoenvironments: International Association for Mathematical Geology Journal, v. 6, no. 4, p. 333-352.

Peck, J. H., Jr., and McFarland, H. B., 1954, Whitfield collection types at the University of California: Journal of Paleontology, v. 28, no 3, p. 297-309, 1 pl.

Pielou, E. C., 1966a, Species-diversity and pattern-diversity in the study of ecological successions: Journal of Theoretical Biology, v. 10, p. $370-383$.

1966b, The measurement of diversity in different types of biological collections: Journal of Theoretical Biology, v. 13, p. 131-144.

Pojeta, John, Jr., 1979, The Ordovician paleontology of Kentucky and nearby States-Introduction: U.S. Geological Survey Professional Paper 1066-A, $48 \mathrm{p}$.

Pokorný, Vladimír, 1965, Principles of zoological micropalaeontology, v. 2. Translated [from German] by K. A. Allen. Edited by J. W. Neale: New York, Pergamon Press, 465 p.

Pribyl, Alois, 1975, Hastatellina gen. n., eine neue OstracodenGattung und ihre Vertreter aus dem böhmischen und nichtböhmischen Ordovizium: Paläontologische Zeitschrift, v. 49, no. $1 / 2$, p. 11-23, 2 pls.

Reed, F. R. C., 1910, New fossils from the Dufton shales: Geological Magazine, new series, decade 5, v. 7, p. 211-220, 294-299, 4 pls. 
Rome, D. R., and Goreux, Jean, 1960, Cryptophyllus (Ostracodes) du Strunien de la Belgique: Louvain Université, Institut Géologique Mèmoires, v. 21, p. 185-204.

Ruedemann, Rudolf, 1912, The Lower Siluric shales of the Mohawk Valley: New York State Museum Bulletin 162, 151 p., 10 pls. 1926. The Utica and Lorraine formations of New York; Part 2, Systematic paleontology; No. 2, Mollusks, crustaceans, and eurypterids: New York State Museum Bulletin 272, 227 p., 26 figs., 28 pls.

Sarv, Lembit, 1959, Ostrakody Ordovika Ėstonskoi SSR: Eesti NSV Teaduste Akadeemia, Geoloogia Instituudi Uurimused, v. 4, 209 p., 32 pls.

1962, Ostrakody Porkuniskogo gorizonta i Llandoveri Estonii: Eesti NSV Teaduste Akadeemia, Geoloogia Instituudi Uurimused, v. 9 , p. $95-141,9$ pls.

Schallreuter, Roger, 1964, Neue Ostrakoden der Gattungen Platybolbina, Brevibolbina und Oecematobolbina aus mittelordovizischen Backsteinkalkeschieben: Geologische Gesellschaft in Deutschen Demokratischen Republik Berichte, v. 9, no. 3, p. 381-383, 2 pls.

1965, Neue Ostracoden aus mittelordovizischen Backsteinkalkgeschieben: Geologische Gesellschaft in der Deutschen Demokratischen Republik Berichte, v. 10, no. 4, $479-487,3$ pls.

1966a, Zur Taxonomie und Phylogenie der Ostracodenfamilie Ctenonotellidae Schmidt, 1941 (Paleocopina, Hollinacea): Geologie, Jahrg. 15, no. 2, p. 197-208, 4 pls.

1966b, Zur Taxonomie und Phylogenie der Ostrakodenfamilie Tetradellidae Swartz, 1936 (Palaeocopina, Hollinacea) und eine neue Familie der Hollinacea: Geologie, Jahrg. 15, no. 7, p. $846-875,5$ pls.

1967, Neue Ostracoden aus ordovizischen Geschieben: Geologie, Jahrg. 16 , no. 5, p. $615-631$.

1968, Zur Taxonomie und Phylogenie der Eridostraca (Ostracoda): Paläontologische Zeitschrift, v. 42, no. 1/2, p. $105-119,1 \mathrm{pl}$

1969, Untergattungen der Ostrakodengattung Platybolbina: Geologie, Jahrg. 18, no. 7, p. 877-879.

1973, Die Ostracodengattung Hyperchilarina und das Aparchites - Problem: Geologiska Föreningen i Stockholm Förhandlingar, v. 95 , pt. 1, p. 37-49.

1975, Palaeocopine Ostrakoden aus Backsteinkalk-geschieben (Mittelordoviz) Norddeutchlands (mit Ausnahme der Tvaerenellidae, Ctenonotellidae und Tetradellidae): Palaeontographica, Abt. A, v. 149, pt. 4-6, p. 139-192, 11 pls.

1977, On Cryptophyllus gutta Schallreuter: Stereo-Atlas of Ostracod Shells, v. 4 , no. 1, p. 1-8, 6 pls.

Schmidt, E. A., 1942, Studien im böhmischen Caradoc (Zahoran-Stufe), 1. Ostrakoden aus den Bohdalec-Schichten und über die Taxonomie der Beyrichiacea: Senckenbergische Naturforschende Gesellschaft, Abhandlungen 454, 96 p., 5 pls.

Sepkoski, J. J., Jr., 1974, Quantified coefficients of association and measurement of similarity: International Association for Mathematical Geology Journal, v. 6, no. 2, p. 135-152.

Sethi, D. K., 1979, Palaeocope and eridostracan ostracodes, in Jaanusson, Valdar, Laufeld, Sven, and Skoglund, Roland, eds., Lower Wenlock faunal and floral dynamics-Vattenfallet section, Gotland: Sveriges Geologiska Undersökning, ser. C, Avhandlingar och Uppsatser, no. 762, ̊̊ rsbok 73, no. 3, p. 142-166, figs. 41-52.

Shaver, R. H., 1958, A study of Pseudobythocypris pediformis, a new name for an old ostracod: American Midland Naturalist, v. 59, no. 1, p. 120-137.

Shimer, H. W., and Shrock, R. R., 1944, Index fossils of North America: New York, John Wiley, 837 p., 303 pls.
Siveter, David, 1978, The Ordovician, in Bate, R. H., and Robinson, Eric, eds., A stratigraphical index of British Ostracoda: Geological Journal Special Issue 8, p. 41-56, 3 pls.

Smosna, Richard, and Warshauer, S. M., 1978, The evolution of a carbonate shelf, Silurian McKenzie Formation, West Virginia; a cluster analytic approach: Journal of Sedimentary Petrology, v. 48 , no. 1, p. 127-142.

Sneath, P. H. A., and Sokal, R. R., 1973, Numerical taxonomy: San Francisco, W. H. Freeman, 573 p.

Spivey, R. C., 1939, Ostracodes from the Maquoketa shale, Upper Ordovician, of Iowa: Journal of Paleontology, v. 13, no. 2, p. $163-175,1 \mathrm{pl}$.

Spjeldnaes, Nils, 1963, Some silicified Ordovician fossils from South Wales: Palaeontology, v. 6, pt. 2, p. 254-263, 2 pls.

Swadley, W C, Luft, S. J., and Gibbons, A. B., 1975, The Point Pleasant Tongue of the Clays Ferry Formation, northern Kentucky, in Cohee, G. V., and Wright, W. B., Changes in stratigraphic nomenclature by the U.S. Geological Survey, 1974; U.S. Geological Survey Bulletin 1405-A, p. A30-A31.

Swain, F. M., 1962, Early Middle Ordovician Ostracoda of the eastern United States; Pt. 2, Leperditellacea (part), Hollinacea, Kloedenellacea, Bairdiacea, and Superfamily Uncertain: Journal of Paleontology, v. 36 , no. 4, p. 719-744, 3 pls.

Swain, F. M., Cornell, J. R., and Hansen, D. L., 1961, Ostracoda of the families Aparchitidae, Aechminidae, Leperditellidae, Drepanellidae, Eurychilinidae, and Punctaparchitidae from the Decorah Shale of Minnesota: Journal of Paleontology, v. 35, no. 2, p. $345-372,5$ pls.

Swartz, F. M., 1969, Ordovician ostracode Aparchites whiteavesi Jones (1889), and problems of relationships: Journal of Paleontology, v. 43 , no. 5 , p. $1237-1244,1$ pl.

Sweet, W. C., 1979, Conodonts and conodont biostratigraphy of postTyrone Ordovician rocks of the Cincinnati region: U.S. Geological Survey Professional Paper 1066-G, 26 p.

Sweet, W. C., and Bergstrom, S. M., 1976, Conodont biostratigraphy of the Middle and Upper Ordovician of the United States Midcontinent, in Bassett, M. G., ed., The Ordovician System-Proceedings of a Palaeontological Association Symposium, Birmingham, September 1974: Cardiff, University of Wales Press and National Museum of Wales, p. 121-151.

Triebel, Erich, 1941, Zur Morphologie und Ökologie der fossilen Ostracoden. Mit Beschreibung einiger neuer Gattungen und Arten: Senckenbergiana, Bd. 23, nr. 4/6, p. 294-400, 15 pls.

Ulrich, E. O., 1879, Descriptions of new genera and species of fossils from the Lower Silurian about Cincinnati: Cincinnati Society of Natural History Journal, v. 2, p. 8-30, 1 pl.

1889, On some Polyzoa (Bryozoa) and Ostracoda from the Cambro-Silurian rocks of Manitoba: Canada Geological and Natural History Survey, Contributions to the Micro-Palaeontology of the Cambro-Silurian Rocks of Canada, pt. 2, p. 27-57, pls 8-9. 1890-1891, New and little known American Paleozoic Ostracoda: Cincinnati Society of Natural History Journal, v. 13, p. 104-137, 173-211, 12 pls.

1892, New Lower Silurian Ostracoda, no. 1: American Geologist, v. 10 , no. 5 , p. 263-270, 1 pl.

1897, The Lower Silurian Ostracoda of Minnesota: Minnesota Geological and Natural History Survey, Final report, v. 3, pt. 2, Paleontology, p. 629-693, 4 pls. (advance edition, 1894).

Ulrich, E. O., and Bassler, R. S., 1908, New American Paleozoic Ostracoda; Preliminary revision of the Beyrichiidae, with descriptions of new genera: U.S. National Museum Proceedings, v. 35, p. 277-340, 9 pls.

1923, Paleozoic Ostracoda; their morphology, classification, and occurrence: Maryland Geological Survey, Silurian [Volume], p. 271-391, 18 figs. 
Valentine, J. W., and Peddicord, R. G., 1967, Evaluation of fossil assemblages by cluster analysis: Journal of Paleontology, v. 41, no. 2, p. 502-507.

Vesper, Bernd, 1975, To the problem of noding on Cyprideis torosa (Jones, 1850), in Swain, F. M., ed., Biology and paleobiology of Ostracoda-A symposium *** : Bulletins of American Paleontology, v. 65 , p. $205-216$.

Walcott, C. D., 1883, The Utica slate and related formations of the same geological horizon: Albany Institute Transactions, v. 10, p. 1-38, 2 pls. (Advance printing, 1879, by J. Munsell, Albany, N.Y.)

Warshauer, S. M., 1975, The sexual dimorphism and ontogeny of Ceratopsis chambersi (Miller) (Ostracoda, Palaeocopida) from the Upper Ordovician of southwestern Ohio and northern Kentucky: Bulletins of American Paleontology, v. 67, no. 287, p. 443-456, 3 pls.
1981, Cincinnaticoncha, Pseudoprimitiella and Edenopsis; new generic names for Ordovician ostracodes: Journal of Paleontology, v. 55 , no. 4 , p. $885-893,1$ pl.

Warshauer, S. M., and Smosna, Richard, 1977, Paleoecologic controls of the ostracode communities in the Tonoloway Limestone (Silurian; Pridoli) of the central Appalachians in Löffler, Heinz, and Danielopol, Dan, eds., Aspects of ecology and zoogeography of Recent and fossil Ostracoda - Proceedings of the 6th International symposium on Ostracods, Saalfelden (Salzburg), July 30-August 8, 1976: The Hague, Dr W. Junk b.v. Publishers, p. 475-485.

Warthin, A. S., 1948, Ostracode genotypes designated by S. A. Miller: Journal of Paleontology, v. 22, no. 5, p. 645-646.

Weir, G. W., and Greene, R. C., 1965, Clays Ferry Formation (Ordovician) - A new map unit in south-central Kentucky: U.S. Geological Survey Bulletin 1224-B, p. B1-B18. 


\section{INDEX}

[italic page numbers indicate major references]

\section{A}

Abstract

acuminulata, Shenandoia affinis, Schmidtella

Age

alata, Ctenobolbina

americana zygocornis, Bollia

Americoncha

bifurcata

dubia

marginata

multiannulata

Analysis, method of

angularis, Saccelatio

Anisocyaminae

Anisocyamus

excavatus - -

$\mathrm{sp}$

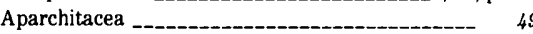

A parchitellina --

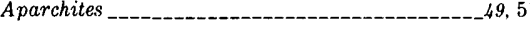

arrectus

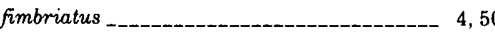

minutissimus trentonensis _..--.--_-_--_-_-- 53

parsispinosus _._-_-_-__-_-_-_-_-_-_-_.- 50

trentonensis --- 53

whiteavesi

sp -

Aparchitidae

Apatochilina

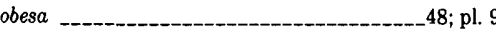

arctus, Punctaparchites rugosus _--_-_-_--_--- 5

arcuamuralis, Saccelatia

arrecta, Saccelatia

arrectus, Aparchites

asymmetrica, Ceratopsis _--_-_.-- $5,33,38,39,40$

Schmidtella pls. $6,7,8$

\section{B}

Bairdiocypridae

Bairdiocyprididae

Bairdiocypris cylindrica

Ballardina

concentrica

millersburgia --_--

minuta

Baltonotella

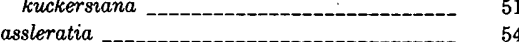

Batostomella sp

Beyrichia buchiana

chambersi

ciliata -

cincinnatiensis -

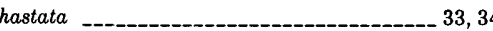

initialis

obliquejugata

oculifera

persulcata

quadrifida

rostrata

(Ceratopsis) duffonensis -.--_-_-_-_-_--- 33

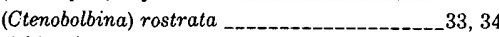

Beyrichicopina

Bibliography

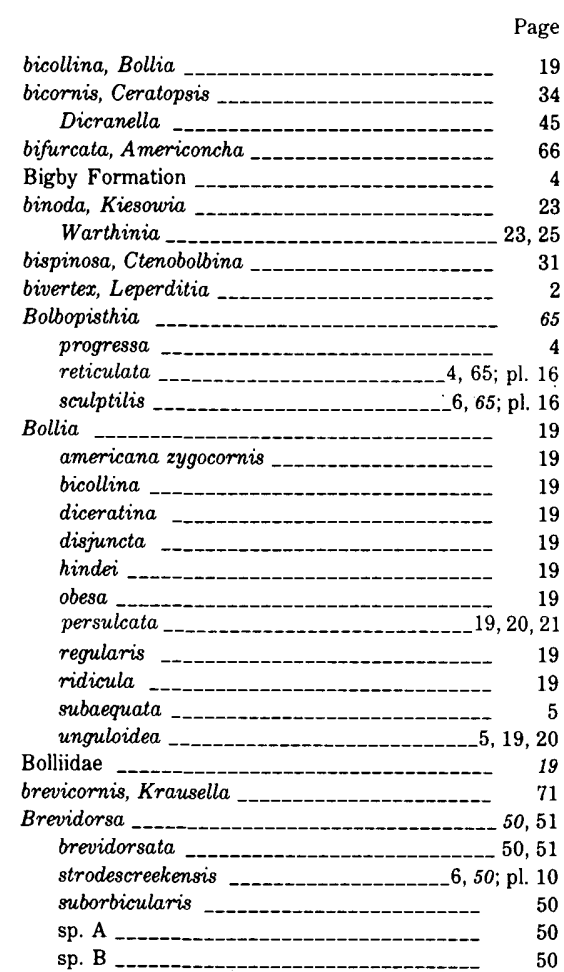

revidorsata, Brevidorsa 50,51

brevidorsata, Brevidorsa
brevis, Schmidtella

brittanica, Ceratopsis

buchiana, Beyrichia

buckensis, Saccelatia

bullata, Saccelatia

Bullatella

Byrsolopsina

uphami

sp --.

Bythocypris -

cylindrica

obliquedorsata

C

caleyi, Daliella

camerata, Parenthatia

Cannon Limestone -

carinata, Thomasatia -

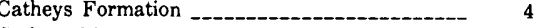

Catheys Limestone $\quad 4,5$

centralis, Laccoprimitia -_-_-_-_-_-_6, 57, 61; pl. 14

Laccoprimitia (Primitia) -_-_---------- 57

Primitia _......._ 2,57

Ceratella

Ceratopsis

asymmetrica -_-_ $5,33,38,39,40$; pls. $6,7,8$

bicornis 34

brittanica

chambersi

$2,5,6,33,34,35,36$

robusta

$37,39,41,44 ;$ pls. 7,8
Page

Ceratopsis-Continued

duftonensis

$6,33,36,39,48 ; \mathrm{pl}, 7$

grandispinosa _-_-_-_- 34

hastata -

humilinoda

intermedia -_-_-_ $2,6,33,35,36,41$; pls. $5,6,7,8$

obliquejugata _-_._- 33 oculifera perpuncta prominens --_-_-_-_-_-_--_ 34 perpunctata prominens.

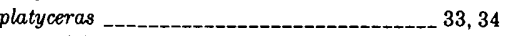
quadrifida _---_--_---_-_-_-_-_-_33, 35, 36, 39; pl. 5 regalis 34 robusta schmidti -

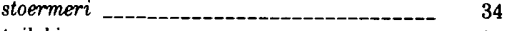

trilobis --- 34

sp - (Ceratopsis) duftonensis, Beyrichia --_-_-_-_ 33 chalazia, Platybolbina (Rimabolbina) _-_._- 47 chambersi, Beyrichia $2,5,6,33,34,35,36,37$ $39,41,44$; pls. 7,8

Tetradella

chambersi robusta, Ceratopsis

Chilobolbinidae

ciliata, Beyrichia

Ctenobolbina

(1)

ciliata parva, Ctenobolbina

Cincinnati, Ohio _-_-_-_-_-_-_-_ 2

Cincinnatian Provincial Series _--------_----- 2

cincinnatiensis, Beyrichia

Milleratia

61

lays Ferry Formation

--57; pl. 14

$1,2,4,5,10$

cletifera, Saccelatia

Coburn Formation

concentrica, Ballardina 28,$29 ; \mathrm{pl} .3$

Conchoprimites

Conchoprimitia

copelandi, Quasibollia

Corbin Ranch Formation

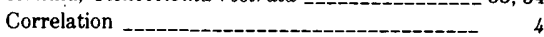

corrugata, Primitia _- 62

Covington, Ky -_-_-_-_-_-_-_-_-_- 2

crassimarginata, Schmidtella _-______54,55, 56; pl. 12

crassiumbonata, Easchmidtella ...----_---- 56

crepidiformis, Jonesella

crepiformis, Leperditia

Cryptophyllidae _-_._pls. 13, 14

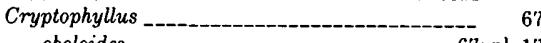

oboloides _._._. 67 ; pl. 17

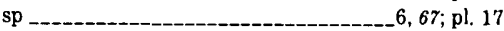

Ctenobolbina

alata

bispinosa -_._- 31

ciliata 31,32

parva

$-4,31$

rostrata cornuta 33,34

ventrispinifera _._______________ 6 , 29; pl. 4

(Ctenobolbina) rostrata, Beyrichia _... 33,34 


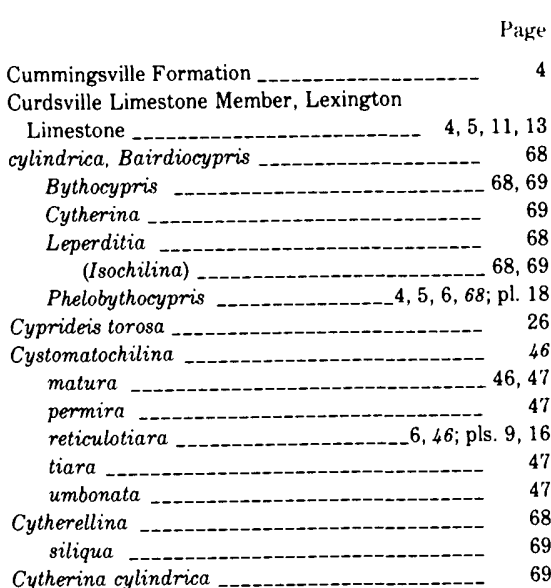

Daliella caleyi

Decorah Formation

Ion Dolomite Member

Denley Formation

Devils Hollow Member, Lexington Limestone -.--

diceratina, Bollia

icranella

bicornis

fragilis

marginata $4,6,45 ; \mathrm{pl} .9$

sp _-_._- 6,45 ; pl. 9

diminucarina, Ectoprimitia _._-_-__-__._-_6, 62; pl. 14

Diplopsis

disjuncta, Bollia

donsi, Piretopsis _-_- 34

Drepanellacea - -

dubia, Americoncha _...-_-_-_-_- 6, 66,

dufionensis, Beyrichia (Ceratopsis) _-_._-_... 33 Ceratopsis

$33,34,39,44$

Easchmidtella crassiumbonata _...- 56 sinuidorsata _-_-_-_-_-_-_-_-_-_-_6, 56 ; pl. 12

Ectoprimitia 62 diminucarina _-_ 62 , pl. 14 $\mathrm{sp}$ Eden Formation --_-_- 4 elegans, Primitiopsis _-.-_- 52 elegantula, Eridoconcha

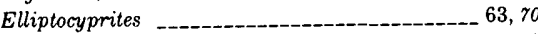
longula parallela sp Eoaquapulex _-_-_-_- 49 socialis

Eohollina irregularis _.-_-_-_- 23

Eridoconcha $\quad 54,56,66,6^{\prime}$

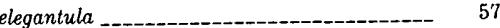
murginata

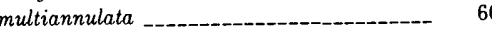
oboloides _..-_-_-_-_-_-_-_-_-_-_-_-_ 67 rugosa 67 ; pl. 17 Eridoconchidae -Eridostraca --_-

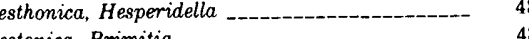

estonica, Primitia -_-_-_-_-_-_-_----- 5,46

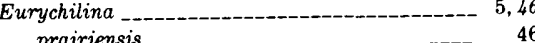

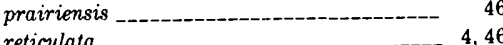
reticulata --_- $4,6,46 ; \mathrm{pl}$. subradiata -------c-o- 5 Eurychilinacea Eurychilinidae -..--..-_- 46 excavatus, Anisocyamus

\section{F}

Page

fimbriata, Ceratopsis _-_-_-_-_6, 33, 36, 39, 49; pl. 7 fimbriatus, Aparchites ...___ 4,50 Fountain, Minn fragilis, Dicranella

franklinensis, Uninodobolba _______ 6, 62; pl. 14

Galena Group

Galena shales

Gephyropsis

trachyreticulata

Clossomorphitinae

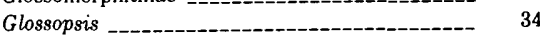

Glymmatobolbina praenuntia

gonyloba, Jonesella --_-_--_-_

$\begin{array}{lr}\text { gregaria, Leperditella } & 51 \\ \text { Grier Limestone Member, Lexington Limestone } & 4,5,11\end{array}$

$\mathrm{H}$

Halliella

retifera

retifera

astata, Beyrichia

Ceratopsis

Hastatellina

normandiensis

posthastata

trilobis

Healdiacea

Healdianella

Hemiaechminoides

Hermitage Formation

Hermitage Limestone

Hesperidella

esthonica

- 48 sp

High Bridge Group

hindei, Bollia

Hollinacea

huilensis, Pseudoprimitiello

humilinoda, Ceratopsis

Hyperchilarina

ovata

50,$51 ;$

inaequalis, Krausella

incompta subaequalis, Schmidtella

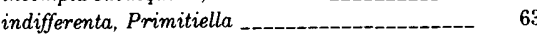

initialis, Beyrichia -..-- 48

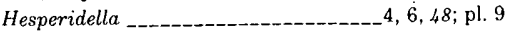
Kloedenia

insolens, Kiesowia

intermedia, Ceratopsis _-_._-_._._4, 4, 33, 35, 36, 41; pls. $5,6,7,8$

Introduction

Ion Dolomite Member, Decorah Formation

irregularis, Eohollina _-_-_-_-_-_-_-_-_-_ 23

(Isochilina) cylindrica, Leperditia minutissima, Leperditia

Jomesella crepidiformis

gonyloba

2,27

obscura

6,$27 ;$ pl. 3$$
\text { Kayina }
$$$$
\text { (n) }
$$

$\begin{array}{lr}\text { Kayina } & \\ \text { kentuckyensis, Silenis } & 54 \\ \text { Kiesowia binoda } & \\ \quad \text { insolens }\end{array}$
Kiesowia binoda-Continued nodosa

verrucosa

23, 25

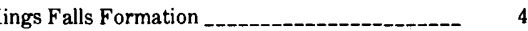

Kloedenellocopina -

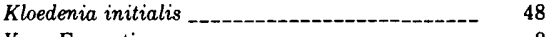

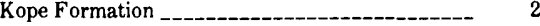

Krausella

brevicornis _-_._- 71

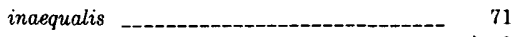

$\mathrm{sp}$

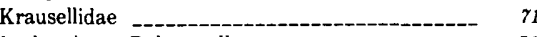

kuckersiana, Baltonotella

L

labiosa, Halliella

Oepikella

Laccoprimitia

centralis

$6,57,61 ;$ pl. 14

$\quad 6,57,60$; pls. 13,14

cryptomorphologica _-_._-_6, 57, 59, 61; pls. 13,14

rudis _-______-_ $6,58,60 ;$ pls. 13,14

shideleri

pl. 14

(Primitia) centralis

latus, Pseudoaparchites -

Leperditella _-_-_-_- 4,52

canalis -_-_-_-_

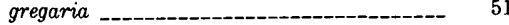

perplexa

rex

tumida ------ 6, 52 ; pl. 11

Leperditellacea -

Leperditellidae - -

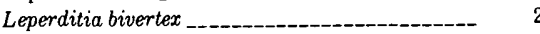

crepiformis _-_-_-_ 2,27

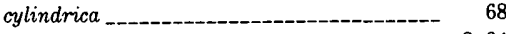

unicornis - 2, 2,64

(Isochilina) cylindrica _-_-_-_-_-_-_-_ 68, 69 minutissima

Lexington Limestone

(See also particular member)

lindstroemii Bythocypris

Localities

Lomatopisthiidae

Longiscula

longula, Elliptocyprites

lunatifera, Tetradella

\section{M}

macrocarinata, Dicranella _-_-_-_-_-_-_-_-_-_ 45

Macrocyproides _-_. 53

trentonensis _-_-_-_-_-_-_-_-_-_-_-_--_ 5,53

sp - -

Macronotella
scofieldi $-[-1-$

sp

Maratia micula

marginata Americoncha

67.0

Dicranella

Eridoconcha

Placentula -

matura, Cystomatochilina ______________ 46, 47

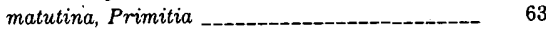

Metacopina

michiganesis, Hesperidella _._-_-_-_-_-_-_-- 48

micula, Maratia

Milleratia $\quad 57,61,67$ cincinnatiensis _._. perminima _-__-_ 61 ; pl. 14 shideleri

Millersburg Member, Lexington Limestone _._-- $\quad 10$

millersburgia, Ballardina _..._-______-_6, 28; pl. 3

minuta, Ballardina

minutissima, Leperditia (Isochilina)

minutissimus trentonensis, Aparchites _..._..._- 53

Moorea punctata 26

multiannulata, Americoncha _-___-_-_-_67 pl. 17 Eridoconcha

.




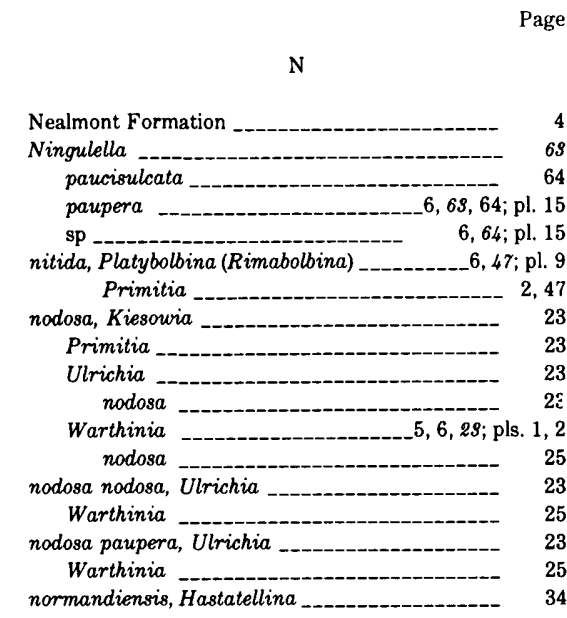

0

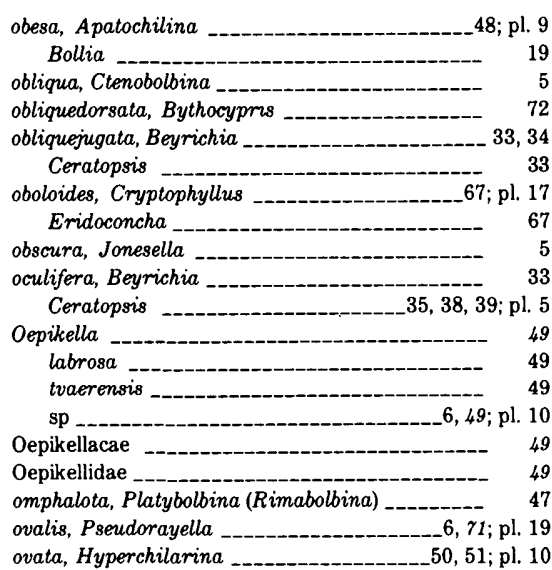

Palaeocopida

Paleoecology

Parabairdiacypris

Parabolbina staufferi

parallela, Elliptocyprites

Paraschmidtella

planilateralis

Parenthatia

camerata

punctata

reticulata

sadievillensis

parva, Ctenobolbina ciliata _-_-_-_-_-_-_-_-_-_-- 4,31

paucisulcata, Ningulella

Primitiella

paupera, Ningulella

Ulrichia nodosa

Warthinia nodosa

perminima, Milleratia

Primitia -

permira, Cystomatochilina

perplexa, Leperditella _._________________-_6, 5s; pl. 11

perpuncta prominens, Ceratopsis _._...-_- 34

perpunctata, Ceratopsis _-_-_-_-_-_-_-_-_-_--_ 33, 34

perpunctata prominens, Ceratopsis _-_-_-_-_-_- 33

Perryville Limestone Member, Lexington

Limestone

11,13

persulcata, Beyrichia

Bollia -

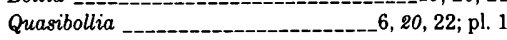

Phelobythocypris

$4,5,68 ;$ pl. 18

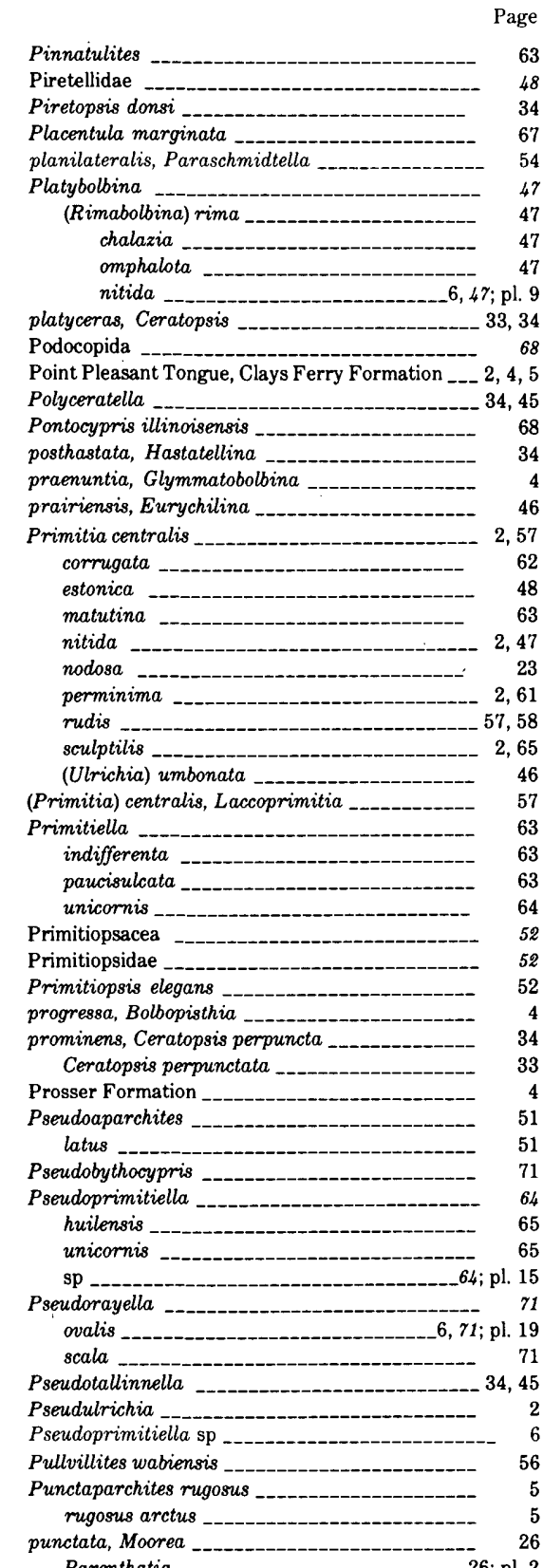

Parenthatia

\section{Q}

Q-mode cluster analysis

Ceratopsis -_-_-_-_-_ $33,35,36,39$; pl. 5

Quadrijugator -

Quasibollia

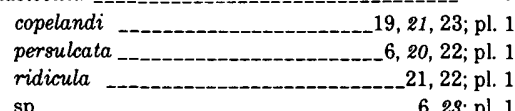

sp _-

\section{R}

regalis, Ceratopsis regularis, Bollia Reversocypris reticulata, Bolbopisthia _._._._._____-_4, 65; pl. 16

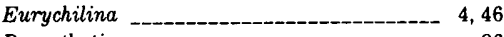

1 Page

reticulotiara, Cystomatochilina _____._6, 46; pls. 9, 16 retifera, Halliella _._-_-_-_-_-_-_-_-_-_ 65 Reversocypris _- 71

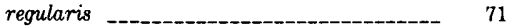
$\mathrm{sp}$ rex, Leperditella $\begin{array}{ll}\text { Richinidae } & \\ \text { ridicula, Bollia } & \end{array}$

Quasibollia

21,22 ; pl. 1

rima, Platybolbina (Rimabolbina)

(Rimabolbina), Platybolbina

chalazia, Platybolbina _._._._-___________- 47

nitida, Platybolbina _..

omphalota, Platybolbina _-_-_-_-_-_-_-_ $\quad 47$

rima, Platybolbina - 47

Rishonidae

robusta, Ceratopsis

Ceratopsis chambersi 33

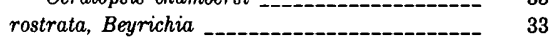

Beyrichia (Ctenobolbina) -------------- 33, 34

rostrata cornuta, Ctenobolbina _.______- 33,34

rudis, Laccoprimitia _______ $6,58,60 ;$ pls. 13,14

Primitia _-_.- 57, 58

rugosa, Eridoconcha

rugosus, Punctaparchites

rugosus arctus, Punctaparchites -_------ 5

$\mathrm{S}$

Saccelatia

51

angularis

arcuamuralis

arrecta

buckensis _-_-_-_-_-_-_-_-_-_-_-_-_-_ 51

bullata - 51

cletifera --_--- 51

sp _... 6,$51 ; \mathrm{pl}, 10$

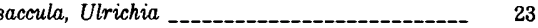

Warthinia 25

sadievillensis, Parenthatia _._-______-_6, 6 ; pl. 2

Salona Formation

Salvisa Bed of Perryville Limestone Member ---- 13

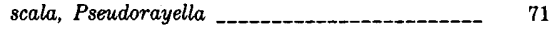

Schmidtella affinis - 5,55

$\begin{array}{lr}\text { asymmetrica _-__- } & 56 \\ \text { brevis } & \end{array}$

crassimarginata -_-_ $54,55,56$; pl. 12

incompta subaequalis -.-- 5

sublenticularis _.__ 55

umbonata

, $55 ; \mathrm{pl} .12$

schmidti, Ceratopsis

scofieldi, Macronotella

sculptilis, Bolbopisthia _.___-_ 65; pl. 16 Halliella

Primitia 2, 65

Shenandoia 68,69

acuminulata - 69 sp -

shideleri, Laccoprimitia -----------------------pl. 14

Milleratia _-

Sigmoopsis -_- 34

Silenis _...-- 70

kentuckyensis -_-_-_-_-_ 60 ; pl. 18

subtriangulatus $\quad 70$

siliqua, Cytherellina

Silus -

sinuidorsata, Easchmidtella

socialis, Eoaquapulex -.-_-_.______-_ 5

Sorenson's coefficient

staufferi, Parabolbina

stoermeri, Ceratopsis -

Stratigraphic framework _-_-_-_-_-_-_-_-_ 5

Strodes Creek Member, Lexington Limestone --- 11

strodescreekensis, Brevidorsa _-__-_-_-_-- 6,$50 ;$ pl. 10

subaequalis, Schmidtella incompta

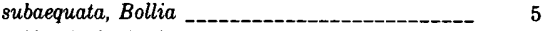

sublenticularis, Schmidtella _._._._._-_____ $\quad 55$

suborbicularis, Brevidorsa -

subradiata, Eurychilina _-_-_-_-_, 6, 46; pl. 9 


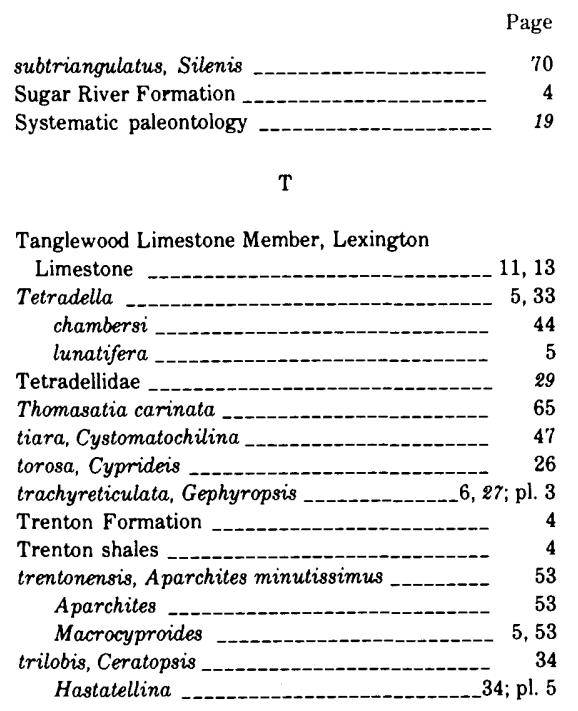

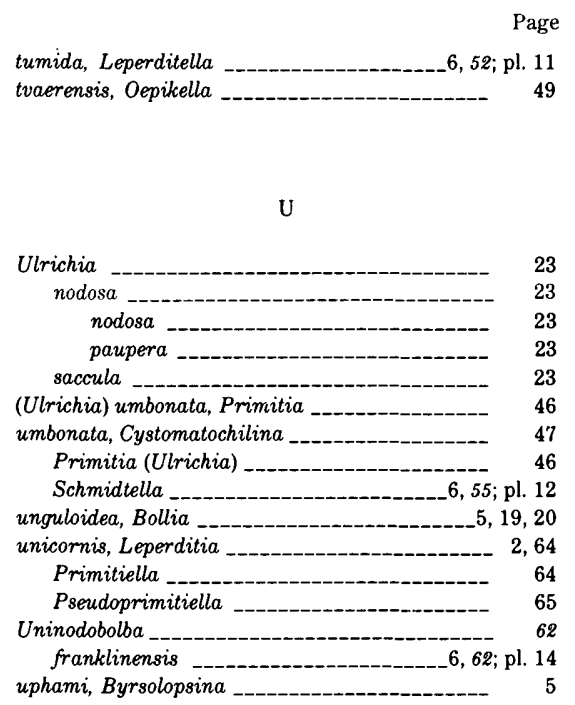

V

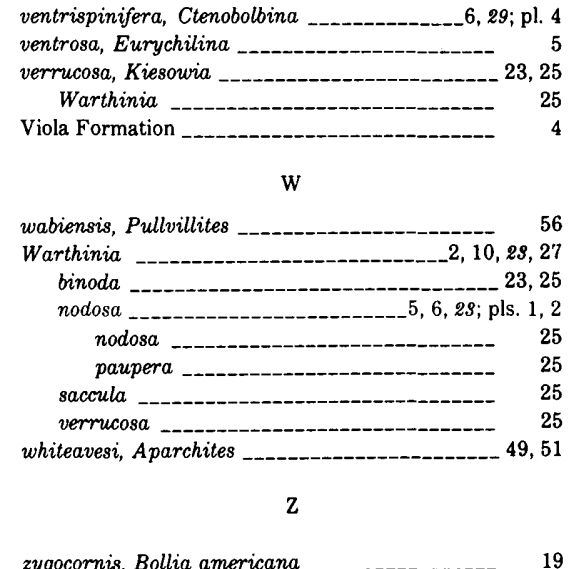

19 


\section{PLATES 1-19}

Contact photographs of the plates in this report are available, at cost, from U.S. Geological Survey Library, Federal Center, Denver, Colorado 80225. 


\section{PLATE 1}

[Figures 6-10 and 19-20 are scanning electron micrographs]

FIGURE 1. Quasibollia copelandi n. sp. (p. H21).

Left valve, holotype, GSC 17084a, from the Middle Ordovician Bucke Formation, Lake Timiskaming, Ontario. $\times 30$.

2. Quasibollia persulcata (Ulrich, 1879) (p. H20).

Right valve, lectotype, USNM 41524a, from the lower Upper Ordovician "Eden Group," lower division, Covington, Ky., according to old USNM label with specimens. $\times 30$.

3. Quasibollia ridicula (Keenan, 1951) (p. H21).

Right valve, topotype, USNM 113457, from the Upper Ordovician Maquoketa Shale, Castlewood, Mo. $\times 30$.

4-10. Quasibollia persulcata (Ulrich, 1879) (p. H20).

4. Left valve, hypotype, USNM 271012, from the Millersburg Member of the Lexington Limestone, USGS colln. 7043-CO. $\times 30$.

5. Right valve, hypotype, USNM 271013, from the Clays Ferry Formation, USGS colln. 7462-CO. $\times 30$.

6. Interior of right valve, hypotype, USNM 239965, from the Clays Ferry Formation, USGS colln. 7471-CO, showing anterodorsal pit, $10^{\circ}$ tilt. $\times 100$.

7, 8. Lateroventral $\left(45^{\circ}\right.$ tilt $)$ and lateral $\left(10^{\circ}\right.$ tilt $)$ views of adult right valve, hypotype, USNM 239963 , from the Millersburg Member of the Lexington Limestone, USGS colln. 7455-CO. $\times 100$.

9. Lateral $\left(10^{\circ}\right.$ tilt) view of adult-3 right valve, hypotype, USNM 239961, from the Millersburg Member of the Lexington Limestone, USGS colln. 7454-CO. $\times 200$.

10. Lateral $\left(10^{\circ}\right.$ tilt) view of phosphatic mold, hypotype, USNM 239966 , showing anterodorsal node represented by pit in fig. 6 and divided L2. These features are not present on adult valve exteriors. Specimen from the Millersburg Member of the Lexington Limestone, USGS colln. 7454-CO. × 200.

11. Quasibollia? sp. (p. H23)

Internal mold of right valve, figured specimen, USNM 240016. $\times 30$.

12-21. Warthinia nodosa (Ulrich, 1890) (p. H23).

12. Left valve, paralectotype, USNM 41552b, from the "Eden Group," Cincinnati, Ohio, according to old USNM label with specimens. $\times 30$.

13-15. Dorsal, left-lateral and right-lateral views of lectotype, USNM 41552a, from the "Eden Group," Cincinnati, Ohio, according to old USNM label with specimens. $\times 30$.

16, 17. Ventral and left-lateral views of hypotype, USNM 271014, from the Tanglewood Limestone Member of the Lexington Limestone, USGS colln. 7467-CO. $\times 30$.

18. Right valve, hypotype, USNM 239972, showing four nodes, from the Clays Ferry Formation, USGS colln. 7471-CO. $\times 30$.

19. Left-lateral view of carapace, hypotype, USNM 239973, from the Clays Ferry Formation, USGS colln. 7472-CO. $\times 30$.

20 . Ventral $\left(75^{\circ}\right.$ tilt) view of adult right valve, hypotype, USNM 239972 , from the Clays Ferry Formation, USGS colln. 7471-CO. $\times 200$.

21. Lateral $\left(13^{\circ}\right.$ tilt) view of adult left valve, hypotype, USNM 239969, from the Clays Ferry Formation, USGS colln. 7471-CO. $\times 200$. 
3

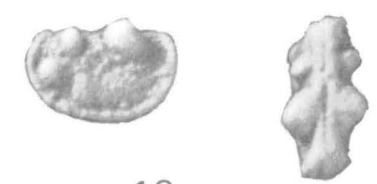

12

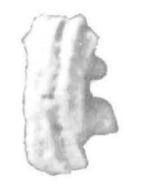

13

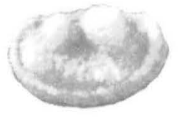

(1)

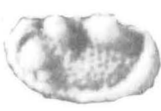

17

18

19

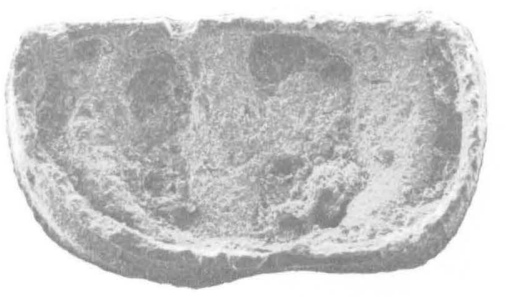

11

16
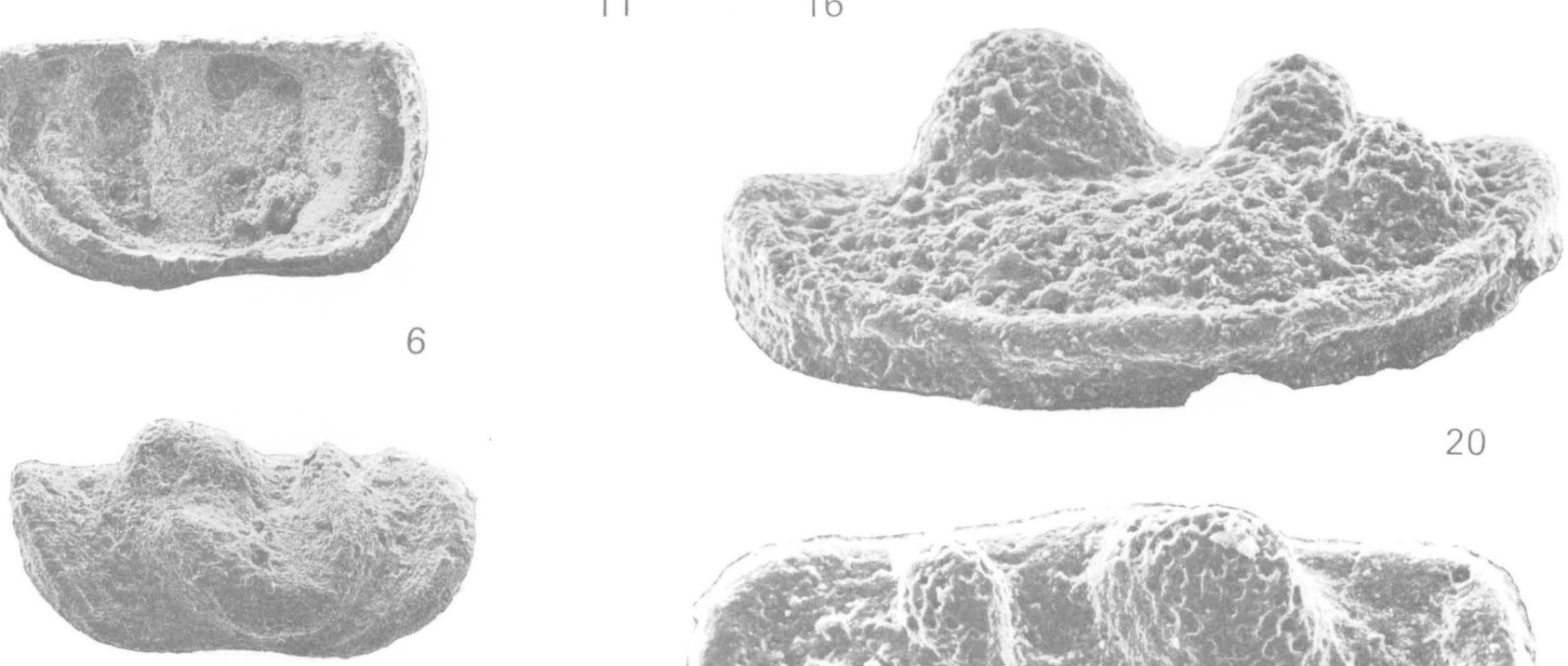

7
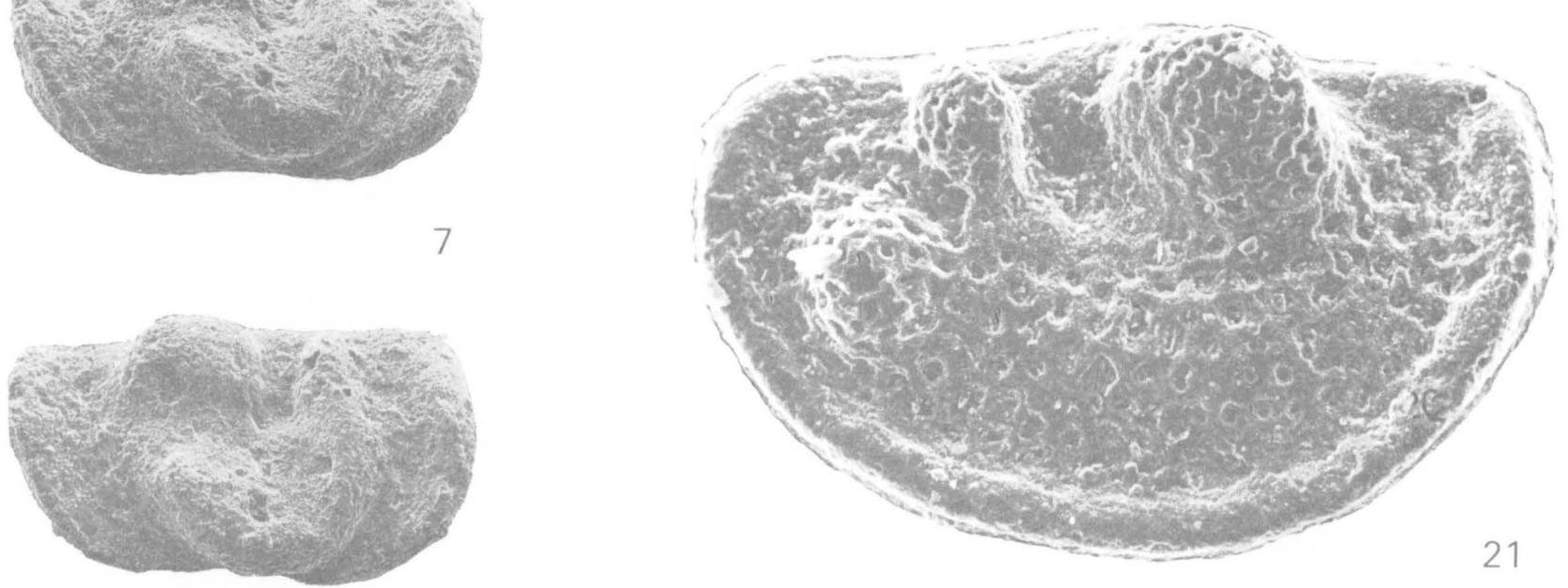

8
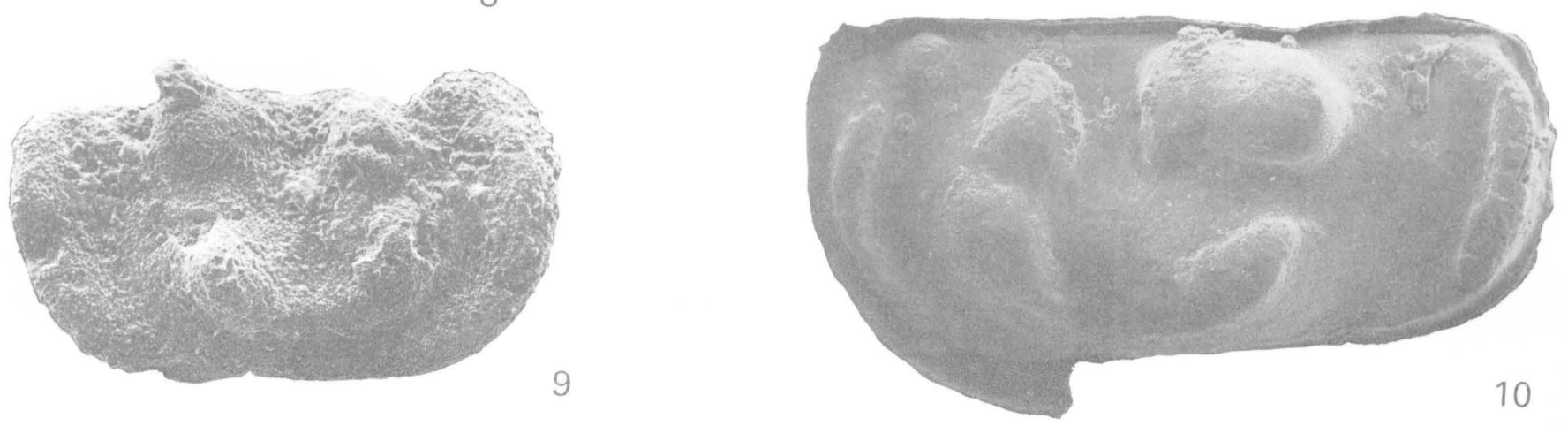

QUASIBOLLIA AND WARTHINIA 


\section{PLATE 2}

[Figures 6-11 are scanning electron micrographs]

Figure 1. Parenthatia punctata (Ulrich, 1894) (p. H26).

Left? valve, lectotype, USNM 41684a, from the "Black River Group, Phylloporina bed," St. Paul, Minn., according to old USNM label with specimens. $\times 30$.

2-8. Parenthatia sadievillensis n. sp. (p. H26).

2. Left valve, holotype, USNM 240035, from the Tanglewood Limestone Member of the Lexington Limestone, USGS colln. 7467-CO. $\times 30$.

3. Right valve, paratype, USNM 271016, from the Tanglewood Limestone Member of the Lexington Limestone, USGS colln. $7467-$ CO. $\times 30$.

4. Right valve, paratype, USNM 271017, from the Tanglewood Limestone Member of the Lexington Limestone, USGS colln. $7467-$ CO. $\times 30$.

5. Left valve, paratype, USNM 271018, from the Clays Ferry Formation, USGS colln. $7468-\mathrm{CO} \times 30$

$6-8$. Left valve, holotype, USNM 240035 , lateroventral $\left(64^{\circ}\right.$ tilt), posteroventral $\left(45^{\circ}\right.$ tilt), and lateral $\left(19^{\circ}\right.$ tilt $)$ views. $\times 200$.

9-11. Warthinia nodosa (Ulrich, 1890) (p. H23).

9. Lateral $\left(13^{\circ}\right.$ tilt) view of juvenile left valve, hypotype, USNM 239967, showing spinelike nodes, from the Clays Ferry Formation, USGS colln. 7468-CO. $\times 200$.

10. Oblique posteroventral $\left(45^{\circ}\right.$ tilt) view of adult-3 left valve, hypotype, USNM 239968 , showing spinose posterior node, from the Clays Ferry Formation, USGS colln. 7468-CO. × 200.

11. Oblique posterodorsal $\left(45^{\circ}\right.$ tilt) view of adult carapace with partly opened valves, hypotype, USNM 239973 , from the Clays Ferry Formation, USGS colln. 7468-CO. $\times 200$. 

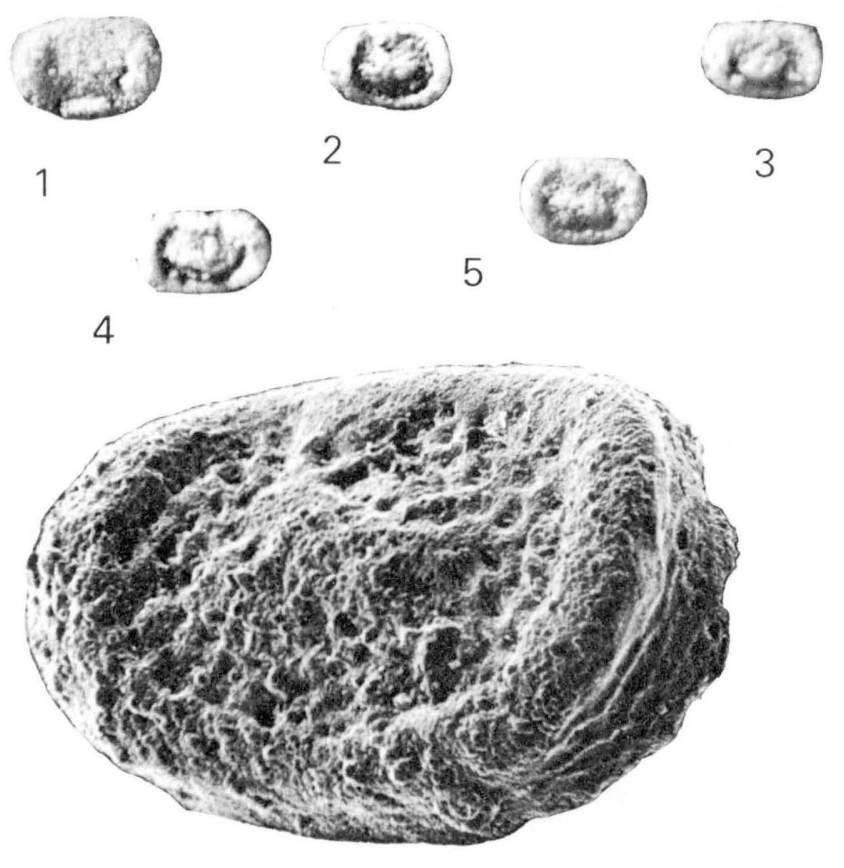

7
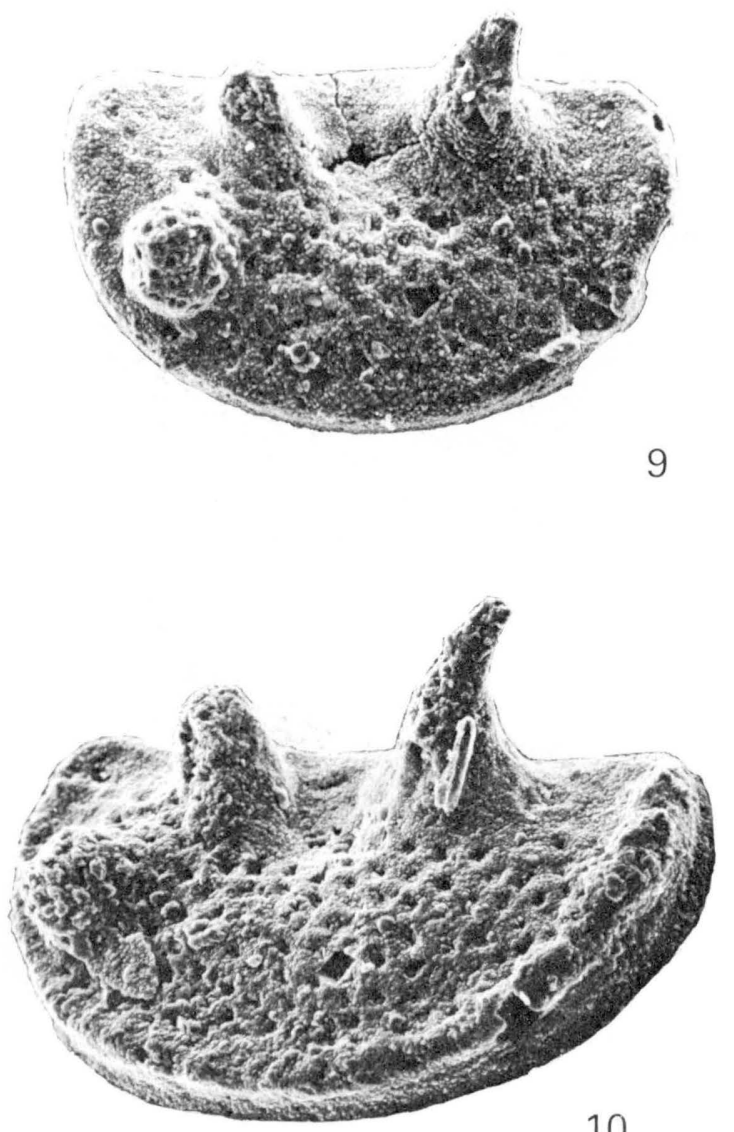

8
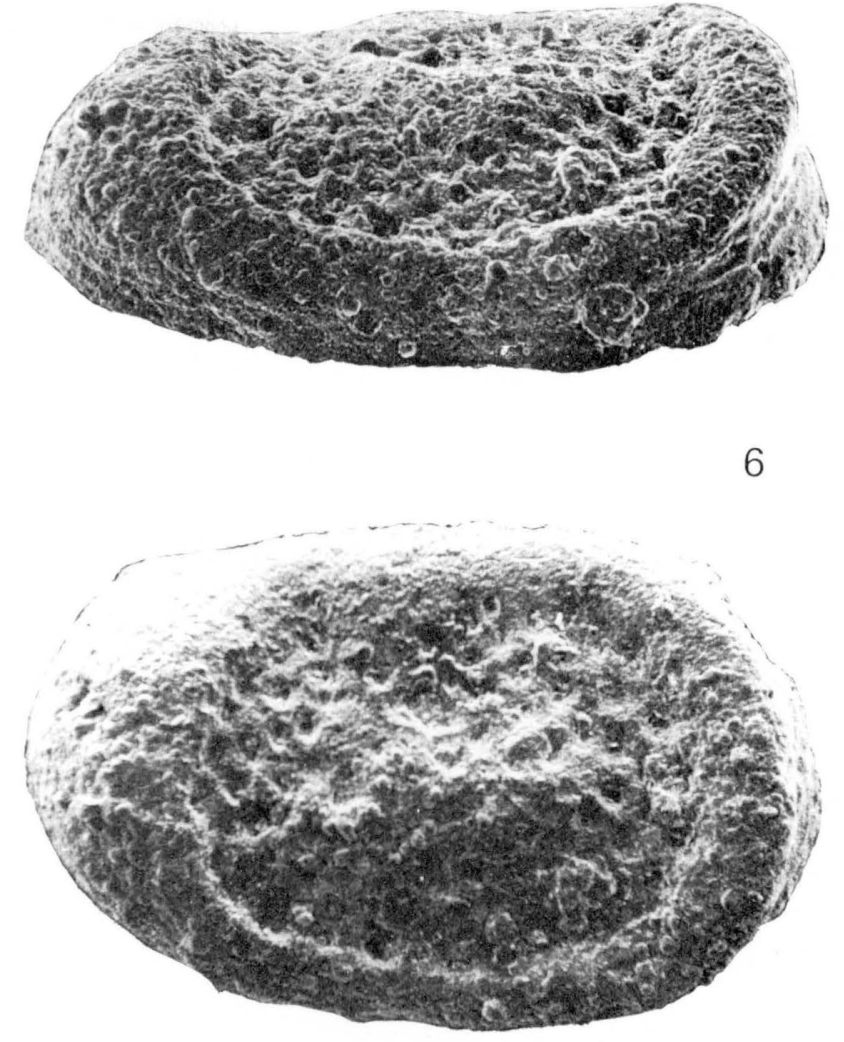

PARENTHATIA AND WARTHINIA 


\section{PLATE 3}

[Figures 6-8, 11, 12, 14, 15 are scanning electron micrographs]

FIGURE 1. Ballardina concentrica Harris, 1957 (p. H29).

Left valve, holotype, MCZ 4619, from the Oil Creek Formation, 2.8 miles north of Springer, Okla. $\times 30$.

2-7. Ballardina millersburgia n. sp. (p. H28).

2, 6, 7. Left valve, holotype, USNM 239983, from the Millersburg Member of the Lexington Limestone, USGS colln. 7455-CO. 2, $\times 30.6,7$. Lateroventral $\left(45^{\circ}\right.$ tilt $)$ and lateral $\left(13^{\circ}\right.$ tilt $)$ views. $\times 100$.

3. Right valve, paratype, USNM 271019, from the Millersburg Member of the Lexington Limestone, USGS colln. $7455-\mathrm{CO} . \times 30$.

4. Right valve, paratype, USNM 239984, from the Millersburg Member of the Lexington Limestone, USGS colln. 7455-CO. $\times 30$.

5. Left valve, paratype, USNM 271020, from the Millersburg Member of the Lexington Limestone, USGS 7455-CO. $\times 30$.

8-12. Gephyropsis trachyreticulata n. gen., n. sp. (p. H27).

8. Lateroventral $\left(65^{\circ}\right.$ tilt) view of holotype, USNM 239975, from the Millersburg Member of the Lexington Limestone, USGS colln. $7454-\mathrm{CO} . \times 200$

9. Left-lateral view of holotype, a carapace. $\times 30$.

10. Right-lateral view of holotype. $\times 30$.

11. Oblique anterolateral view of holotype. $\times 200$.

12. Lateral $\left(13^{\circ}\right.$ tilt $)$ view of holotype, showing reticulation on sigmoid lobe. $\times 200$.

13-15. Jonesella gonyloba n. sp. (p. H27).

13. Right valve, holotype, USNM 239981, from the Logana Member of the Lexington Limestone, USGS colln. D1196-CO. $\times 30$.

14. Lateroventral $\left(45^{\circ}\right.$ tilt) view of holotype. $\times 100$.

15. Lateral $\left(10^{\circ}\right.$ tilt $)$ view of holotype. $\times 100$. 

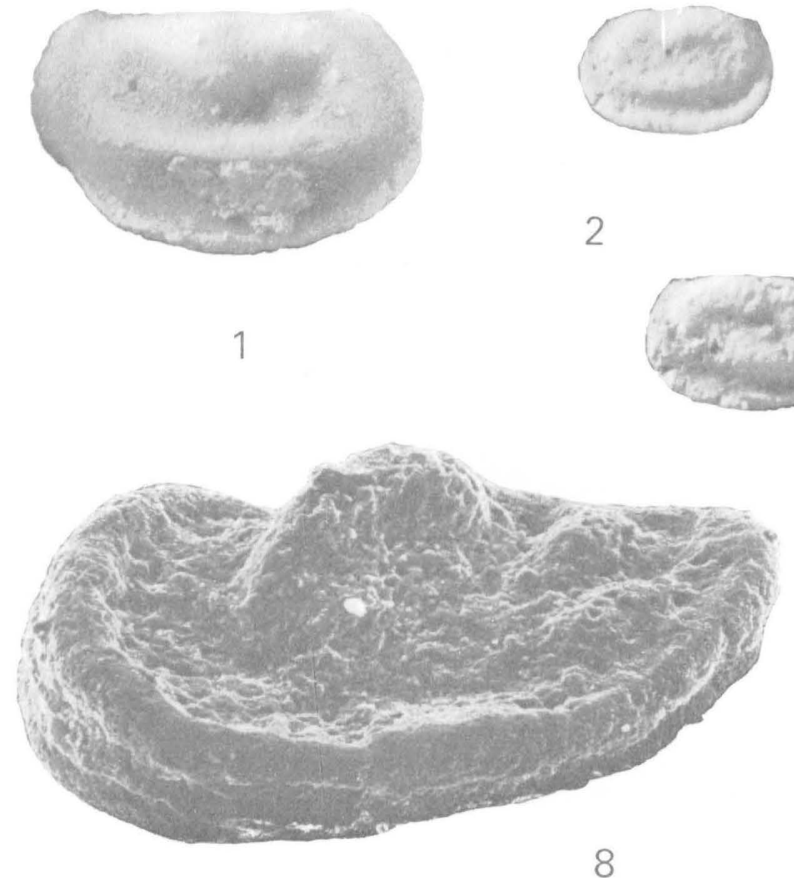

4

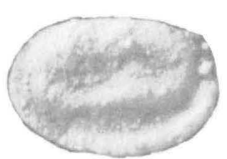

3

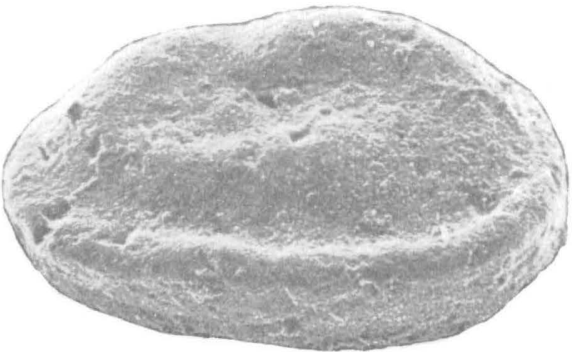

6

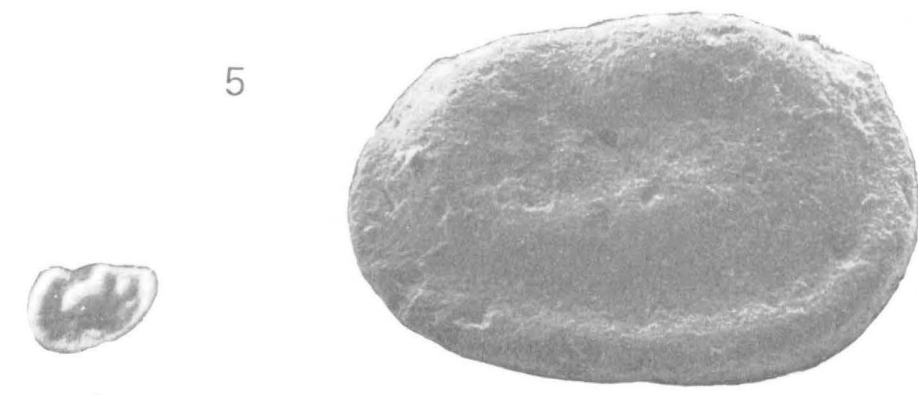

9

7

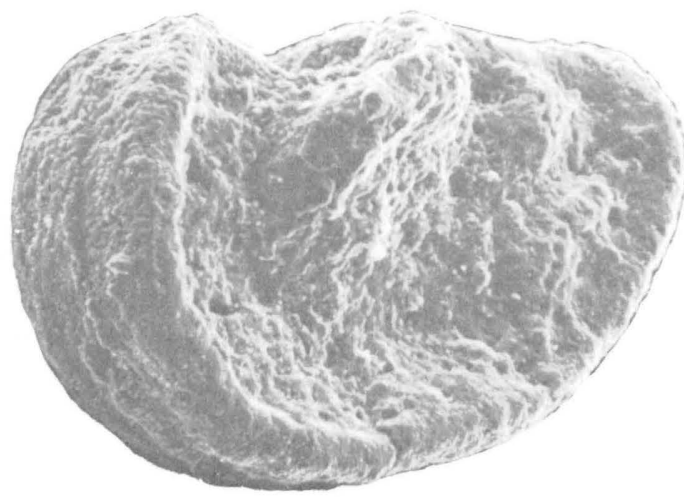

11
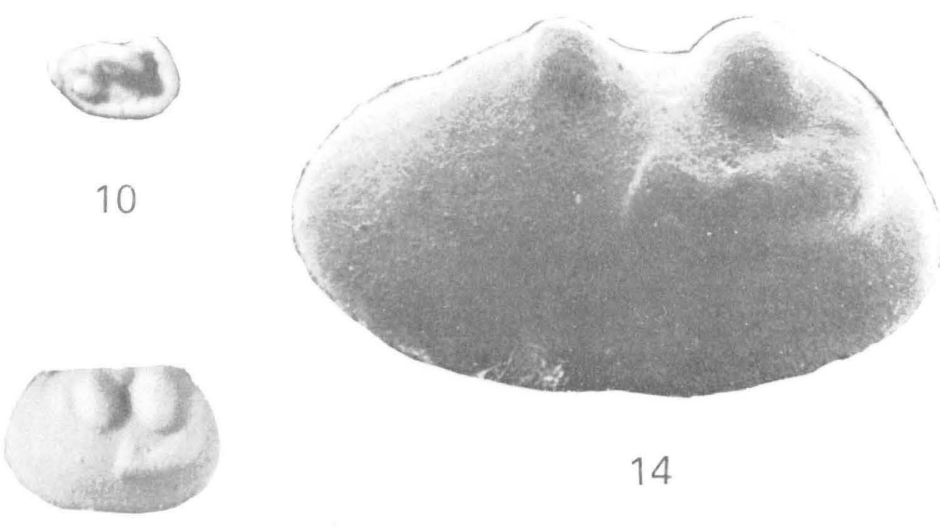

14

13

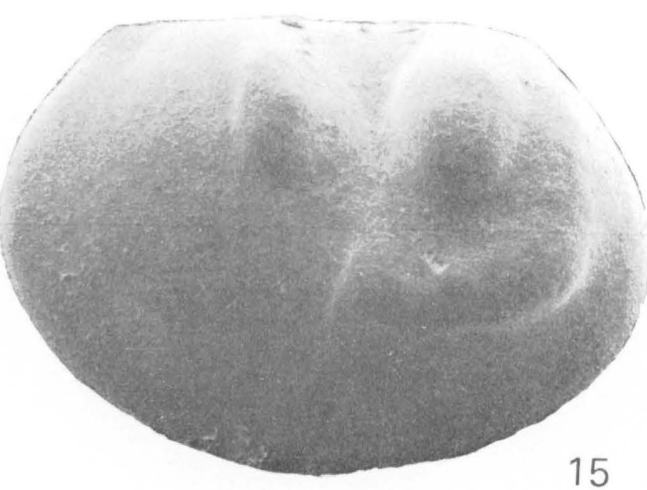

BALLARDINA, GEPHYROPSIS, AND JONESELLA 


\section{PLATE 4}

[Figures 8-10, 12-14 are scanning electron micrographs]

Figures 1-14. Ctenobolbina ventrispinifera n. sp. (p. H29).

All specimens from the Millersburg Member of the Lexington Limestone, USGS colln. 7053-CO.

1, 2. Right-lateral and left-lateral views of juvenile carapace, paratype, USNM 271021. $\times 30$.

3 , 4. Right-lateral and left-lateral views of larger immature carapace, paratype, USNM $271022 . \times 30$.

5. Right-lateral view of adult-1 carapace, paratype, USNM 271023. $\times 30$.

6. Right-lateral view of heteromorphic carapace, paratype, USNM 239978. $\times 30$.

7. Heteromorphic left valve, paratype, USNM 239977. $\times 30$.

8. Lateral $\left(0^{\circ}\right.$ tilt $)$ view of paratype, USNM 239977 , showing spine base. $\times 55$.

9 , 10. Laterodorsal and lateral $\left(9^{\circ}\right.$ tilt) views of adult-3 carapace, paratype, USNM 239979 , showing posterodorsal and postteroventral spines. $\times 100$.

11. Right-lateral view of tecnomorphic carapace, holotype, USNM 239976. $\times 30$.

12,13 . Right-lateral $\left(0^{\circ}\right.$ tilt $)$ and lateroventral $\left(45^{\circ}\right.$ tilt $)$ views of holotype, showing spine base and ventral structures. $\times 65$.

14. Oblique anteroventral $\left(45^{\circ}\right.$ tilt) view of heteromorphic carapace, paratype, USNM 239978 , showing wide antrum and marginal spines. $\times 100$. 


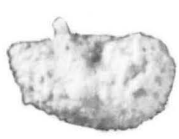

1

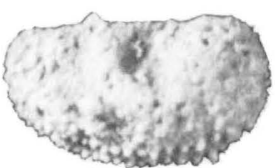

3

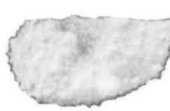

2

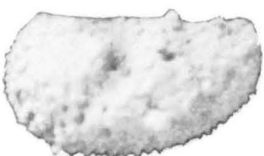

4

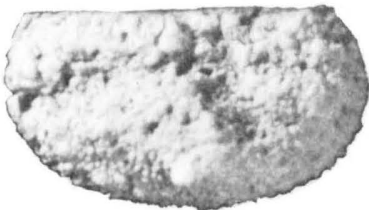

5

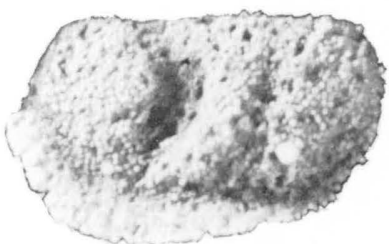

7

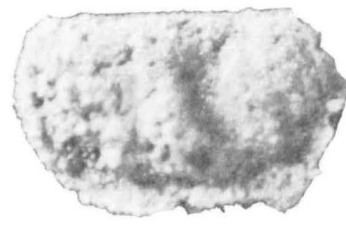

6

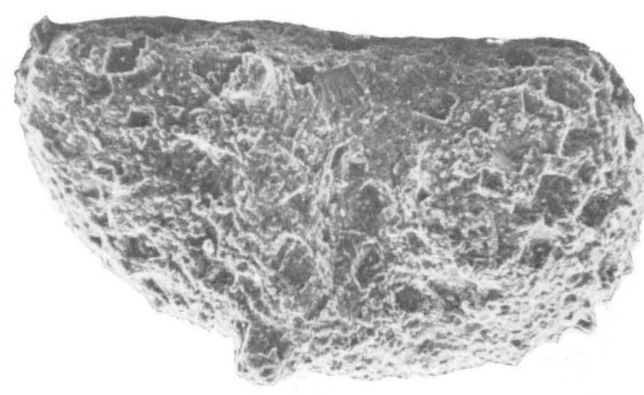

9

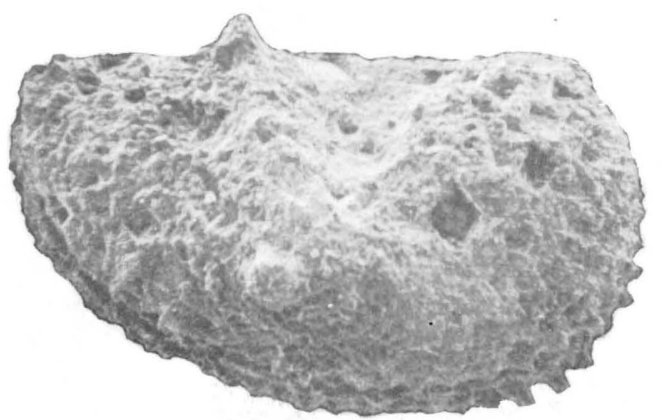

10

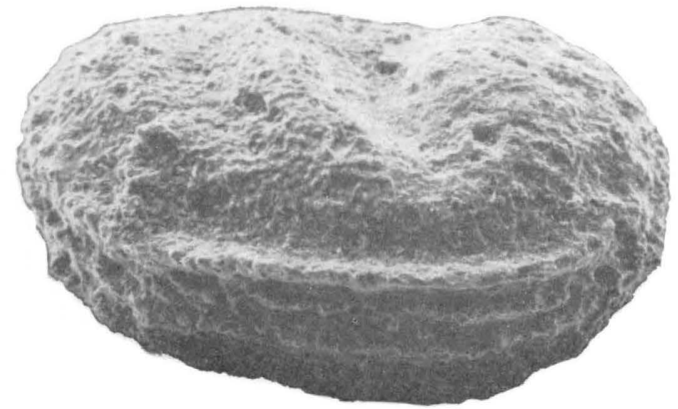

13

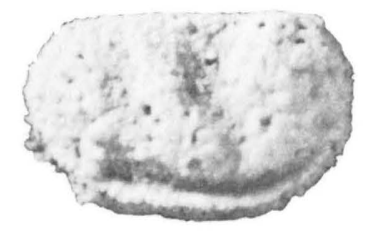

11

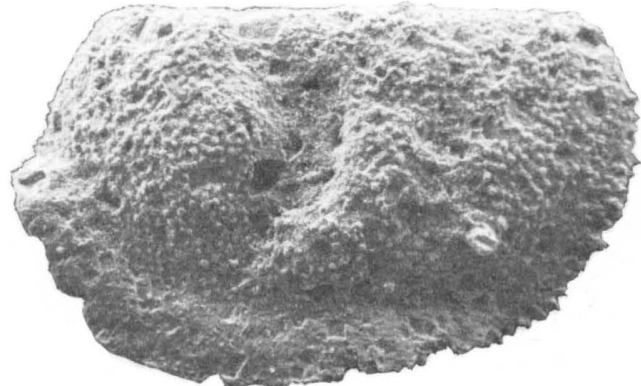

8

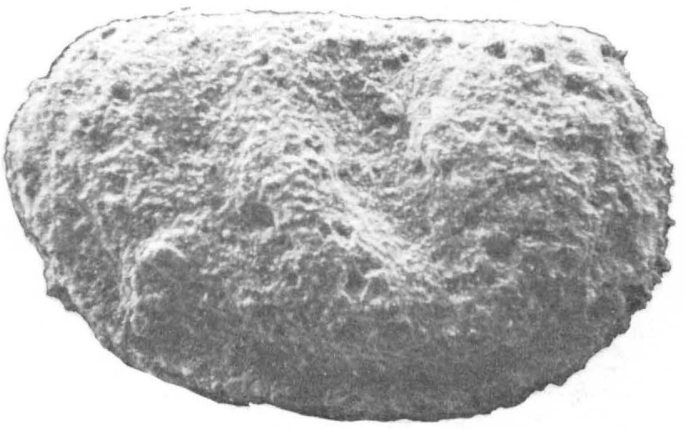

12

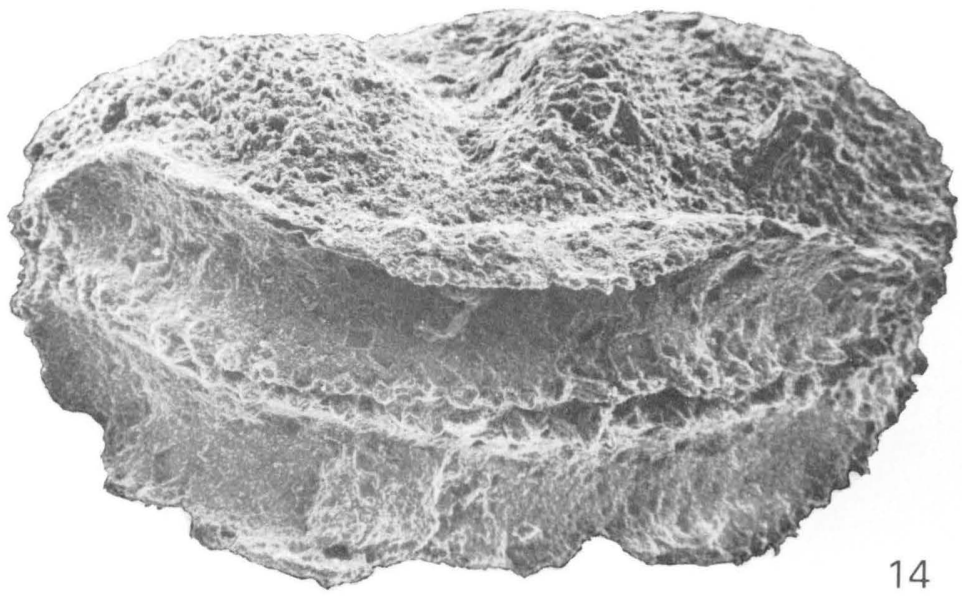

CTENOBOLBINA 


\section{PLATE 5}

[All figures $\times 30$ ]

Figures 1-5. Ceratopsis oculifera (Hall, 1871) (p. H35).

All specimens from the "Hudson-river shales at Cincinnati, Ohio" (Hall, 1871, p. 18)

1. Lateral view of immature tecnomorphic left valve, holotype, UCMP 595/33255

2, 3. Lateral views of two juvenile tecnomorphic right valves, paratypes, UCMP 14655, 14656.

4. Lateral view of tecnomorphic right valve, paratype, UCMP 14657.

5. Lateral view of heteromorphic(?) right valve, paratype, UCMP 14658.

6-12. Ceratopsis intermedia Ulrich, 1894. (p. H36).

All specimens from the "Trenton gr." Bank Lick Creek near Covington, Ky., according to old USNM label.

6. Lateral view of immature tecnomorphic left valve, paralectotype USNM $41500 \mathrm{~B}$, for comparison with holotype of $C$. oculifera.

7. Lateral view of immature tecnomorphic right valve, paralectotype, USNM $41500 \mathrm{C}$.

8. Lateral view of tecnomorphic left valve, paralectotype, USNM 41500D.

9. Lateral view of tecnomorphic right valve, paralectotype, USNM $41500 \mathrm{E}$.

10. Lateral view of immature tecnomorphic left valve, paralectotype, USNM 41500F.

11. Lateral view of tecnomorphic right valve, lectotype, USNM 41500A.

12. Interior view of heteromorphic right valve, showing velum, paralectotype, USNM 41500G.

13-17. Ceratopsis robusta (Ulrich, 1894) (p. H35).

Dorsal, anterior, ventral, right-lateral and left-lateral views of holotype, USNM 41335, from "Richmond, near Spring Valley, Minn., " according to old USNM label.

18. Hastatellina? trilobis (Keenan, 1951) (p. H34).

Lateral view of tecnomorphic right valve, topotype, USNM 113455a, from "Maquoketa, Castlewood, Mo.," according to old USNM label.

19. Ceratopsis quadrifida (Jones, 1891) (p. H35).

Lateral view of broken left valve, holotype, GSC 17707, from "a dark grey, hard limestone, (Trenton) * * * at Lorette Falls, River St. Charles, Province of Quebec." (Jones, 1891, p. 66). 


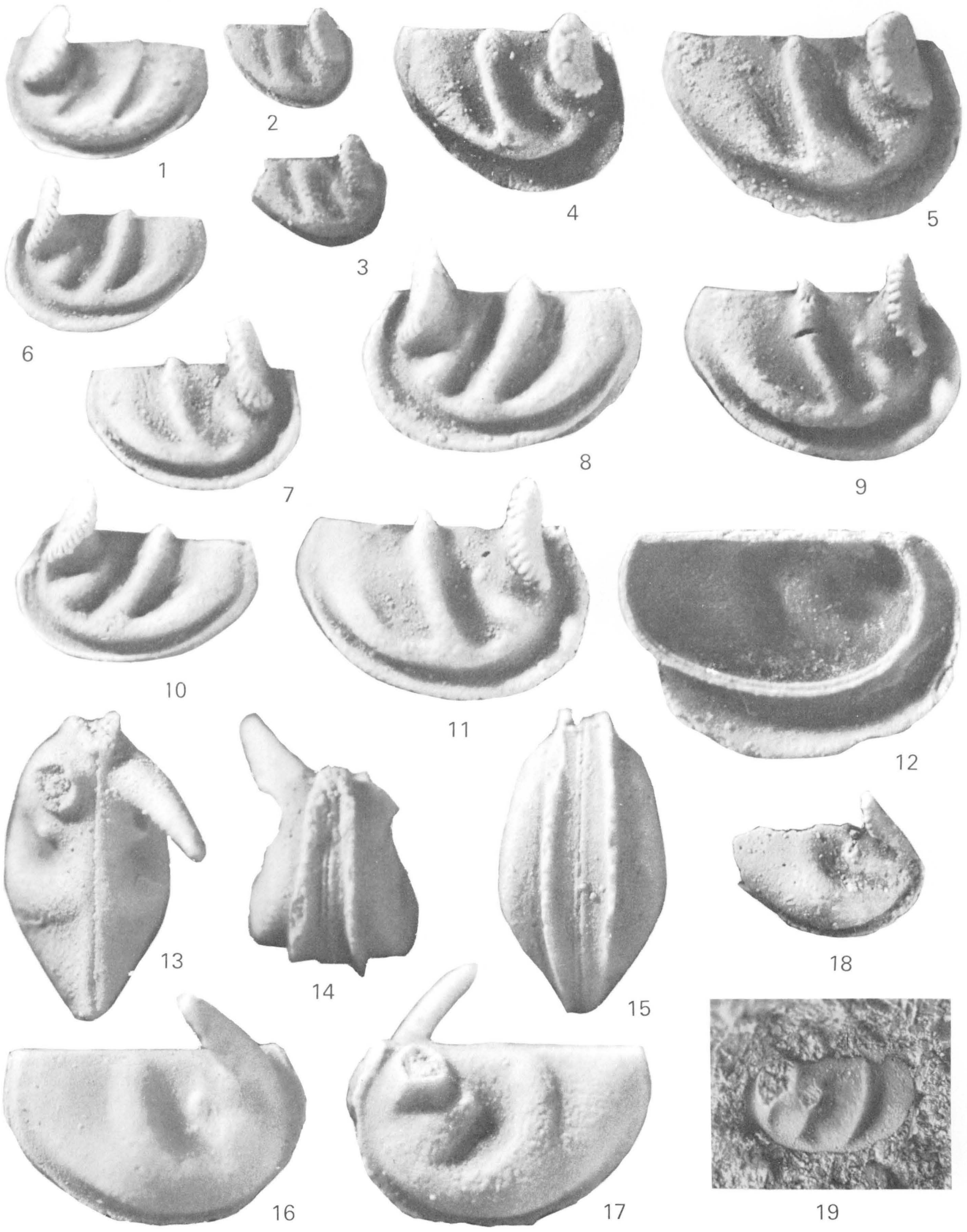

CERATOPSIS AND HASTATELLINA? 


\section{PLATE 6}

[All figures scanning electron nicrographs|

Fliures 1-3, 5, 6. Ceratopsis asymmetrica n. sp. (p. H40).

All figures from Grier Limestone Member of the Lexington Limestone, USGS colln. 4879-CO.

$1,2,5$. Oblique posteroventral $\left(45^{\circ}\right.$ tilt), anteroventral $\left(45^{\circ}\right.$ tilt), and posteroventral $\left(45^{\circ}\right.$ tilt $)$ views of adult tecnomorphic carapace, paratype, USNM 239989, showing unequal width of the subvelar areas on opposing valves. $\times 50$

3, 6. Lateroventral $\left(45^{\circ}\right.$ tilt) and lateral $\left(9^{\circ}\right.$ tilt) views of adult tecnomorphic left valve, holotype, USNM 239988. $\times 50$.

4, 7-10. Ceratopsis intermedia Ulrich, 1894 (p. H36).

All figures from Grier Limestone Member of the Lexington Limestone, USGS colln. 4879-CO.

$4,7,8$. Slightly oblique anteroventral $\left(45^{\circ}\right.$ tilt), oblique posteroventral $\left(45^{\circ}\right.$ tilt), and posteroventral $\left(57^{\circ}\right.$ tilt) views of adult tecnomorphic carapace, hypotype, USNM 239992, showing equal subvelar areas on both valves. $\times 50$.

9 , 10. Lateroventral $\left(45^{\circ}\right.$ tilt) and lateral $\left(9^{\circ}\right.$ tilt $)$ views of adult tecnomorphic left valve, hypotype, USNM 239991. × 50 . 


\section{GEOLOGICAL SURVEY}
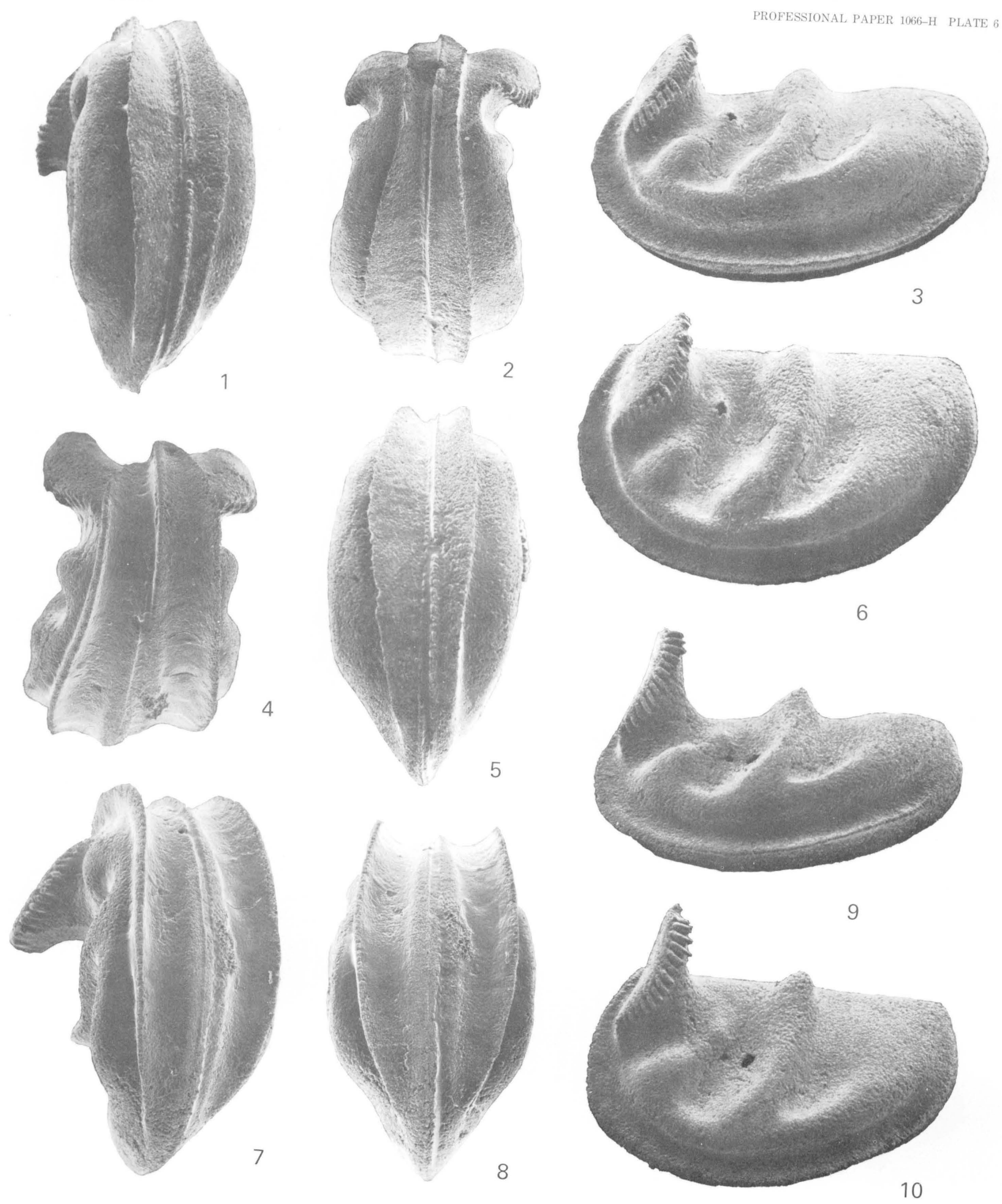

CERATOPSIS 


\section{PLATE 7}

[Figures 9, 16, 17 are scanning electron micrographs]

Flcil'kes 1-5. Ceratopsis sp. (p. H38).

Juvenile specimens (USNM 271024-271028) not certainly referable to species, showing progressive development of S3. All from the Clays Ferry Formation, USGS colln. 6945-CO. $\times 30$.

6-9, 17. Ceratopsis intermedia Ulrich, 1894 (p. H36).

6. Immature right valve, adult-4?, hypotype, USNM 271029, from the Clays Ferry Formation, USGS colln. 6945-CO. $\times 30$.

7. Immature left valve, adult-4?, hyotype, USNM 271030, from the Grier Limestone Member of the Lexington Limestone, USGS colln. 4879-CO. $\times 30$.

8. Adult tecnomorphic left valve, hypotype, USNM 271031, from the Grier Limestone Member of the Lexington Limestone, USGS colln. 4879-CO. $\times 30$

9. Heteromorphic left valve, hypotype, USNM 239994 , lateral view ( $10^{\circ}$ tilt), from the Grier Limestone Member of the Lexington Limestone, USGS colln. D1309-CO. $\times 50$.

17. Oblique anterior view of adult tecnomorphic left valve, hypotype, USNM 239991, showing details of speral process and pores along edge of velar ridge, from the Grier Limestone Member of the Lexington Limestone, USGS colln. 4879-CO. × 100 .

10-12. Ceratopsis asymmetrica n. sp. (p. H40)

10. Immature left valve, adult-4, paratype, USNM 271032, from the Clays Ferry Formation, USGS colln. 6945-CO. $\times 30$.

11. Immature left valve, adult-2, paratype, USNM 271033, from the Grier Limestone Member of the Lexington Limestone, USGS colln. 4879-CO. $\times 30$

12. Adult tecnomorphic left valve, paratype, USNM 271034, from the Clays Ferry Formation, USGS colln. 6945-CO. $\times 30$.

13-15. Ceratopsis fimbriata n. sp. (p. H43).

13. Tecnomorphic left valve, paratype, USNM 240001, from the Clays Ferry Formation, USGS colln. 6945-CO. $\times 30$.

14. Immature left valve, paratype, USNM 240003, from the Clays Ferry Formation, USGS colln. 6945-CO. $\times 30$.

15. Heteromorphic right valve, holotype, USNM 240002, from the Millersburg Member of the Lexington Limestone, USGS colln. 7079-CO. $\times 30$.

16. Ceratopsis chambersi (Miller, 1874) (p. H44).

Lateral $\left(10^{\circ}\right.$ tilt) view of poorly preserved adult tecnomorphic left valve, hypotype, USNM 240004 , from the Clays Ferry Formation, USGS colln. 7478-CO. $\times 46$. 

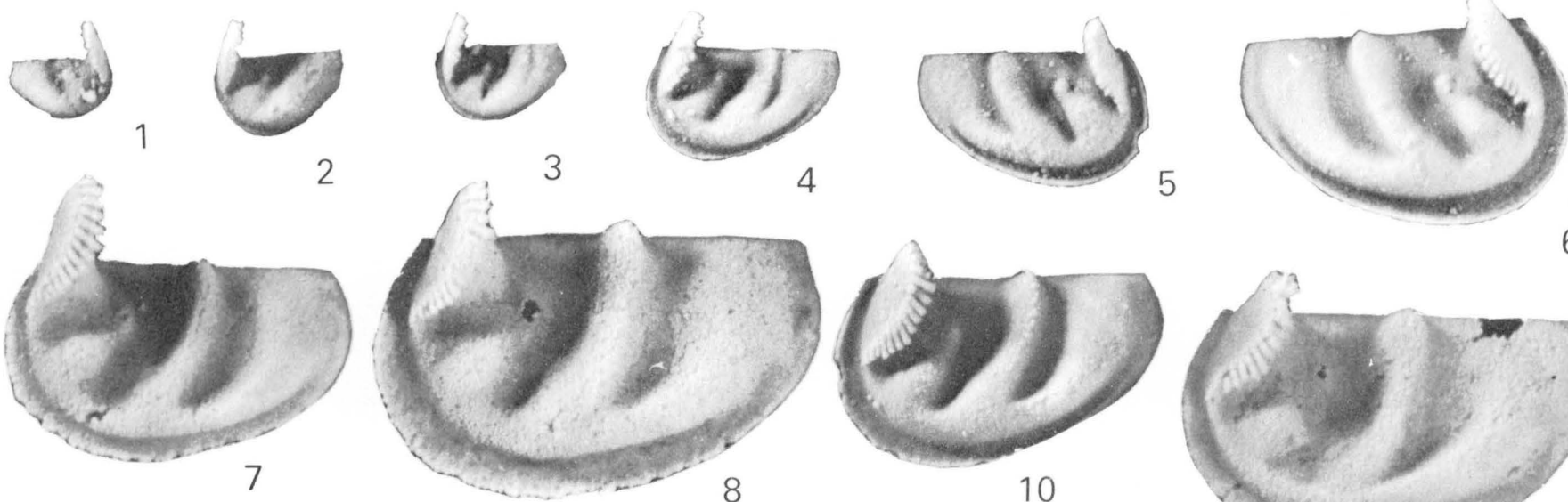

6

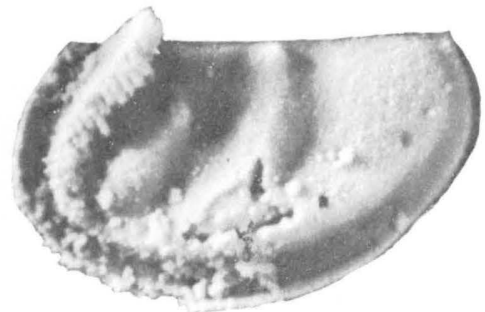

13
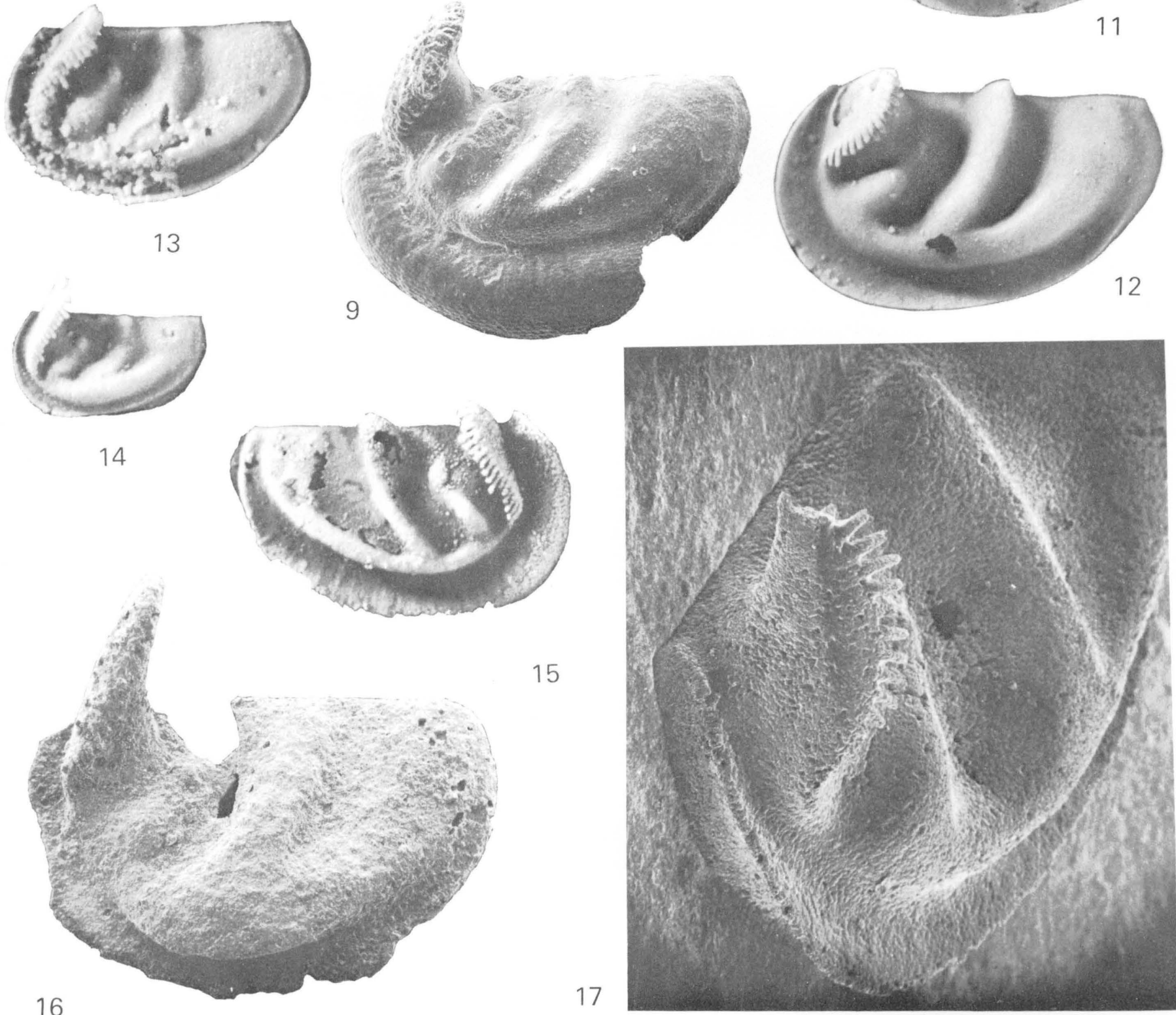

16

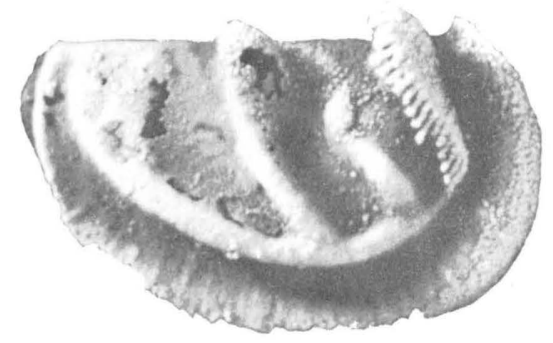

15

17

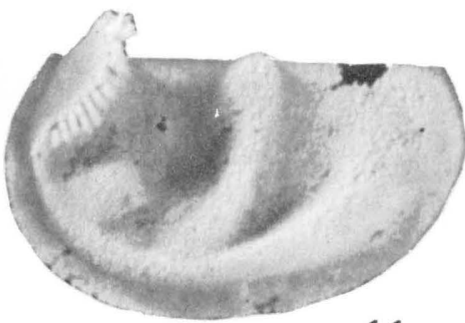

11

14

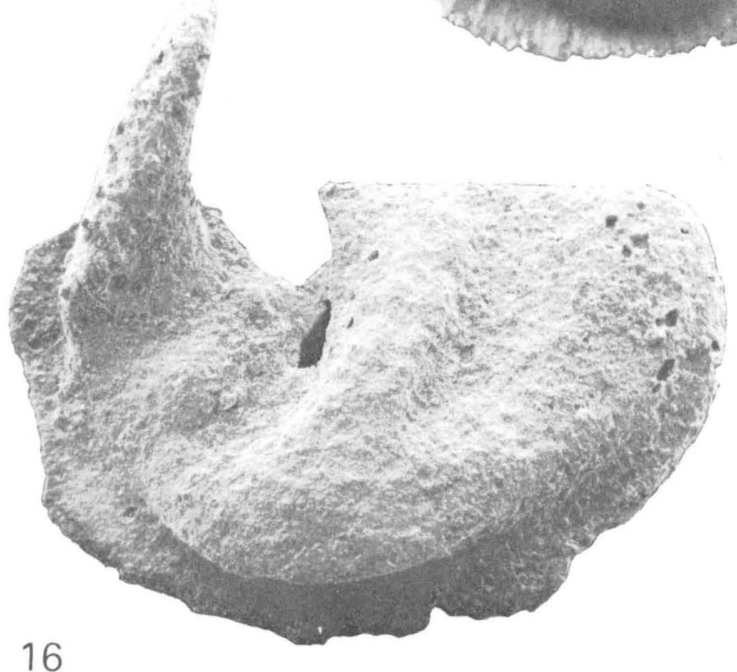

CERATOPSIS 


\section{PLATE 8}

[Figures 3-5, 7, 8, are scanning electron micrographs]

Figures 1-4. Ceratopsis? sp. (p. H45).

1. Right valve, figured specimen, USNM 271035 , from the Clays Ferry Formation, USGS colln. 7477-CO. $\times 30$.

2. Right valve, figured specimen, USNM 240020, from the Clays Ferry Formation, USGS colln. 7477-CO. $\times 30$.

3. Lateral $\left(13^{\circ}\right.$ tilt) view of figured specimen, USNM $240020 . \times 50$.

4. Anterolateral $\left(85^{\circ}\right.$ tilt) view of figured specimen, USNM 240020 , showing merged histial and velar structures. $\times 100$.

5. Ceratopsis chambersi (Miller, 1874) (p. H44).

Lateral $\left(10^{\circ}\right.$ tilt) view of heteromorphic right valve, hypotype, USNM 240005 , from the Clays Ferry Formation, USGS colln. $7471-\mathrm{CO} . \times 50$.

6, 7. Ceratopsis intermedia Ulrich, 1894 (p. H36).

6. Heteromorphic right valve, hypotype, USNM 271036, from the Millersburg Member of the Lexington Limestone, USGS colln. 7079-CO. $\times 30$.

7. Oblique posteroventral ( $45^{\circ}$ tilt) view of tecnomorphic left valve, hypotype, USNM 239991 , showing fimbria on speral process, from the Grier Limestone Member of the Lexington Limestone, USGS colln. 4879-CO. $\times 50$.

8. Ceratopsis asymmetrica n. sp. (p. H40).

Oblique anterior $\left(60^{\circ}\right.$ tilt) view of holotype, USNM 239988 , showing detail of speral process. $\times 100$. 


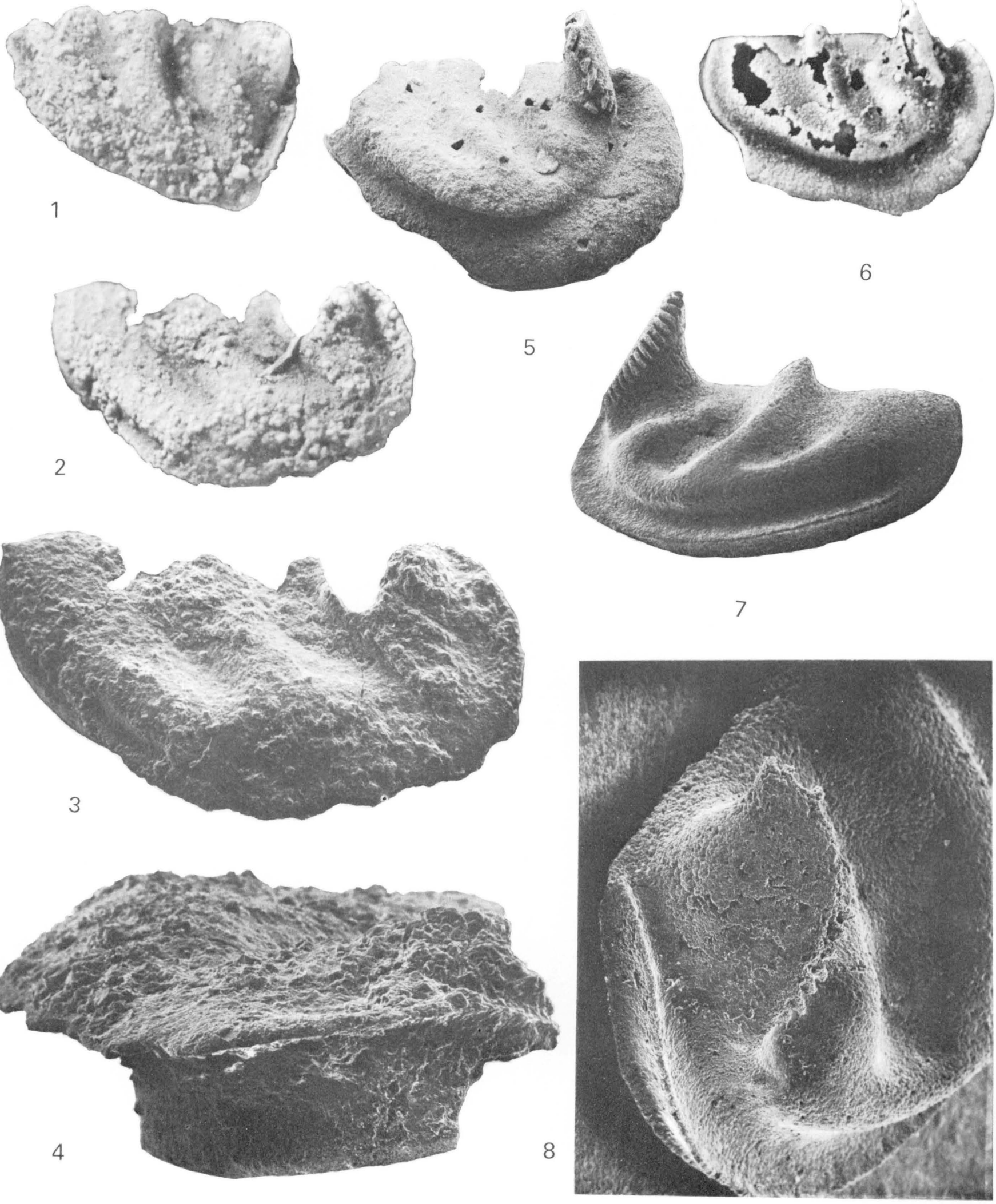

CERATOPSIS? AND CERATOPSIS 


\section{PLATE 9}

|Figures 14, 18 are scanning electron micrographs|

Ficiukes 1-3. Hesperidella? initialis (Ulrich, 1894) (p. H48).

1. Left valve, holotype, USNM 41666, from the Guttenberg Limestone Member of the Decorah Shale, Minneapolis Minn. $\times$ 30 .

2, 3. Left and right valves, hypotypes, USNM 271037, 271038, from the Curdsville Limestone Member of the Lexington Limestone, USGS colln. 5083-CO. $\times 30$.

4. Dicranella sp. (p. H45).

Right valve, figured specimen, USNM 271039, from the Millersburg Member of the Lexington Limestone, USGS colln. 7041-CO. $\times 30$.

5. Dicranella? marginata Ulrich, 1894 (p. H45).

Broken left valve, holotype, USNM 41368, from the Guttenberg Limestone Member of the Decorah Shale, near Fountain, Minn. $\times 30$.

6. Dicranella? sp. aff. D.? marginata Ulrich, 1894 (p. H45).

Left valve, figured specimen, USNM 271040, from the Curdsville Limestone Member of the Lexington Limestone, USGS colln. 5083-CO. $\times 30$.

7, 8. Platybolbina (Rimabolbina) nitida (Ulrich, 1890) (p. H47).

7. Right valve, holotype, USNM 41334, from the Perryville (?) Limestone Member of the Lexington Limestone near Paris, Ky, (float). $\times 30$.

8. Right valve, topotype, USNM 41334a, on chip with holotype. $\times 30$.

9. Apatochilina obesa (Ulrich, 1890) (p. H48).

Left? valve, holotype, USNM 41624, from the Camp Nelson Limestone, High Bridge, Ky. $\times 30$.

10-14, 18. Cystomatochilina reticulotiara n. sp. (p. H46).

10. Right valve, holotype, USNM 240027, from the Strodes Creek Member of the Lexington Limestone, USGS colln. 7318-CO. $\times 30$.

11. Right valve, paratype, USNM 240029, from the Strodes Creek Member of the Lexington Limestone, USGS colln. 7325-CO. $\times 30$.

12. Right valve, paratype, USNM 240028, from the Strodes Creek Member of the Lexington Limestone, USGS colln. 7312-CO. $\times 30$.

13. Right valve, paratype, USNM 240030, from the Strodes Creek Member of the Lexington Limestone, USGS $7312-\mathrm{CO}, \times 30$.

14. Slightly oblique posterolateral view of holotype, specimen at approximately $4^{\circ}$ tilt, showing concentric striae on velum and partioning of velum along radial lines. $\times 150$.

18. Posteroventral part of domicilium of holotype, approximately $36^{\circ}$ tilt, showing reticulation, radial and concentric ornamentation on velum, and nodes at junction of domicilium and velum. $\times 500$.

15-17. Eurychilina subradiata Ulrich, 1890 (p. H46).

15. Broken right valve, hypotype, USNM 271041, from the Curdsville Limestone Member of the Lexington Limestone, USGS colln. 5083-CO. $\times 30$.

16. Left valve, topotype, USNM 41614a, on same chip of rock with syntype USNM 41614 showing punctate ornamentation. $\times 30$.

17. Left valve, syntype, USNM 41614, from the Platteville Limestone at Dixon, Ill. $\times 30$. 


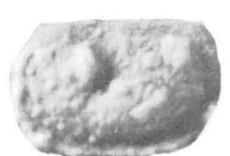

1

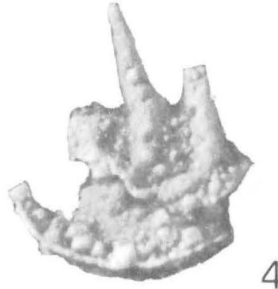

4

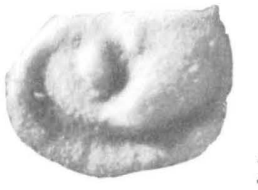

\section{2}
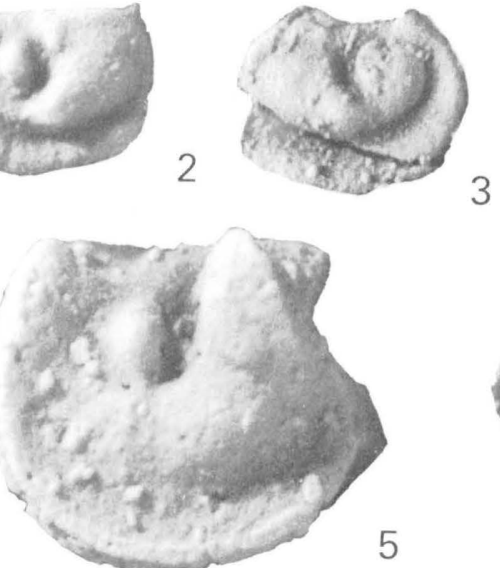

5
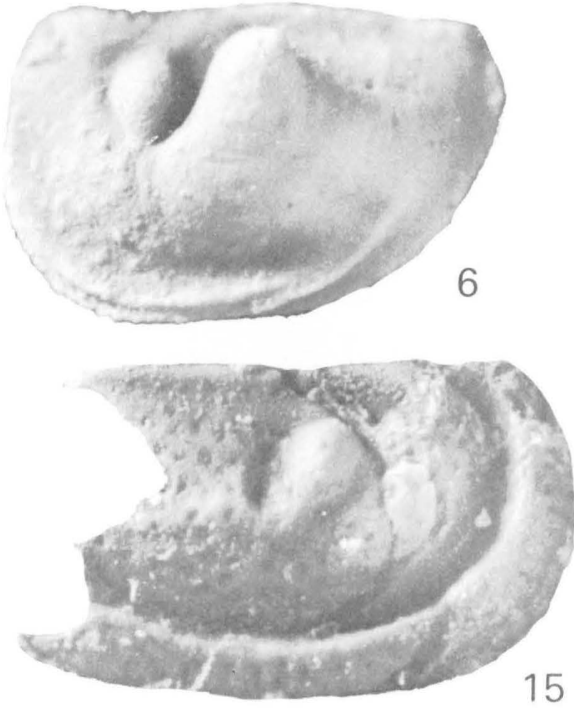

15
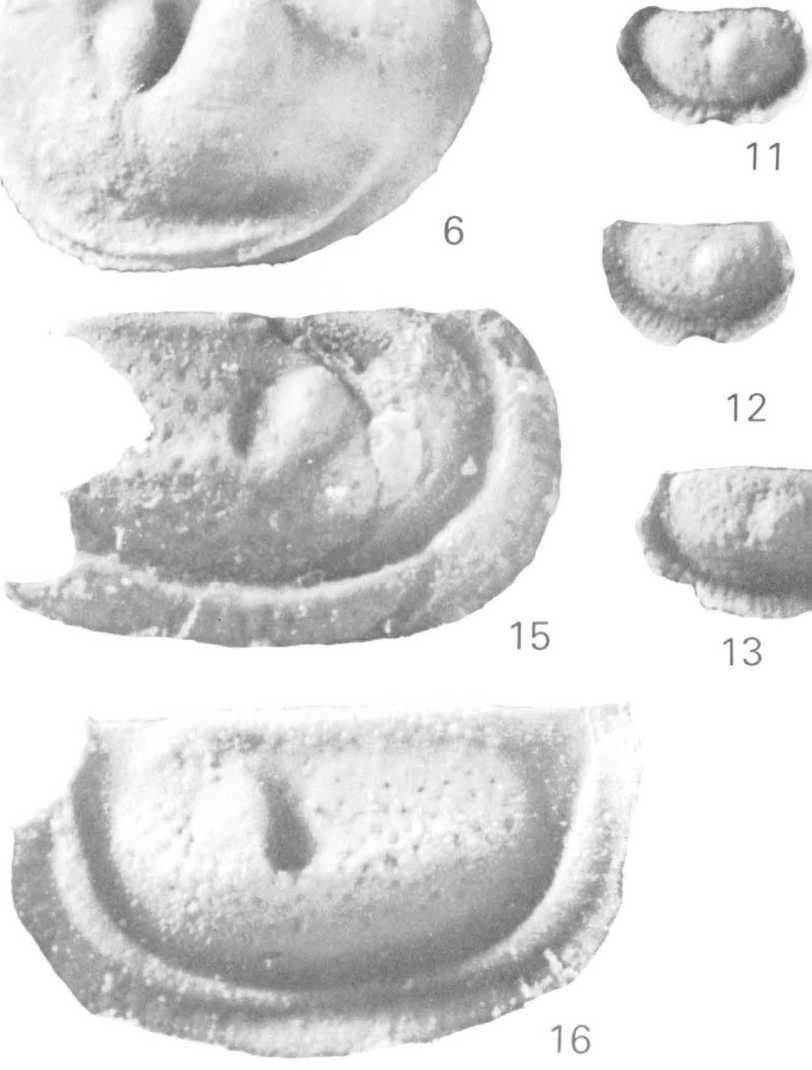

11

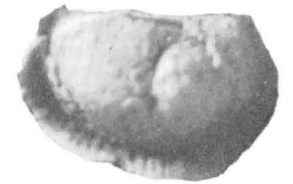

10

12

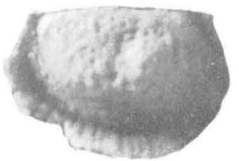

13

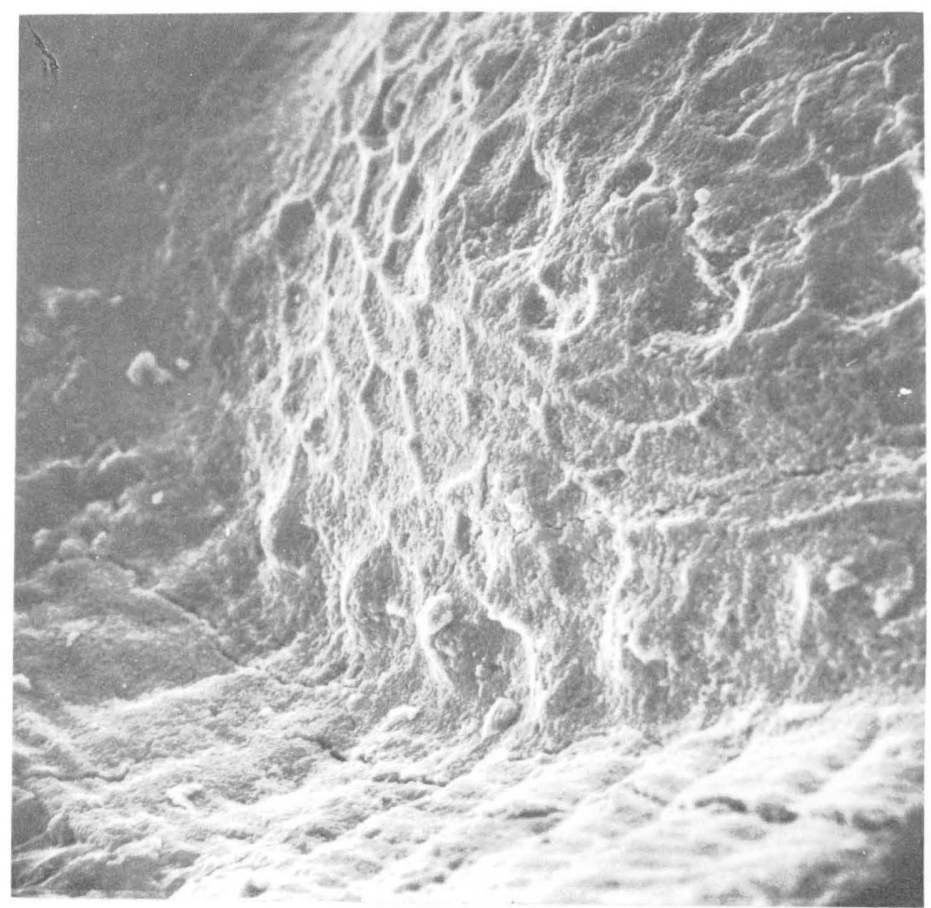

17
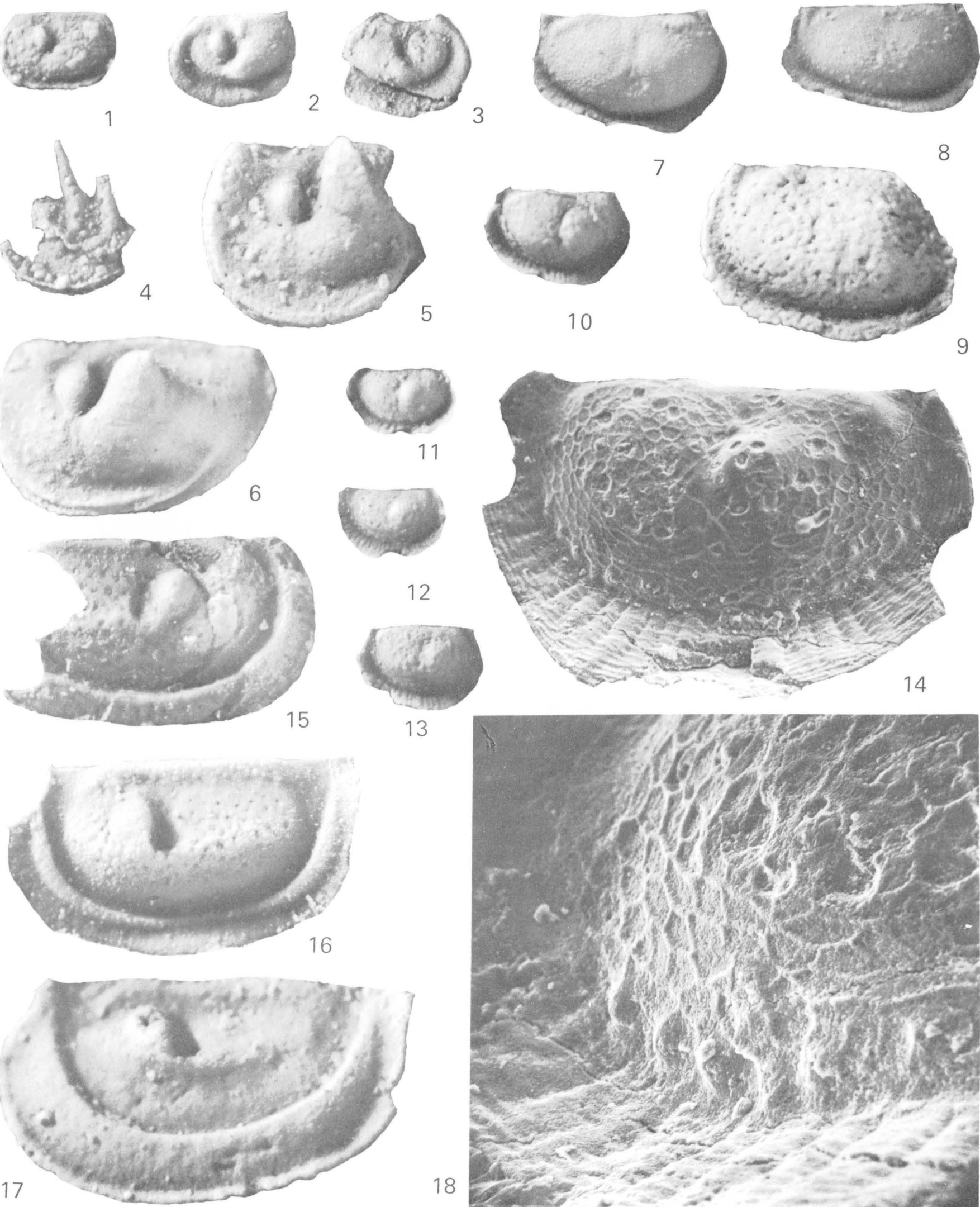

8

7
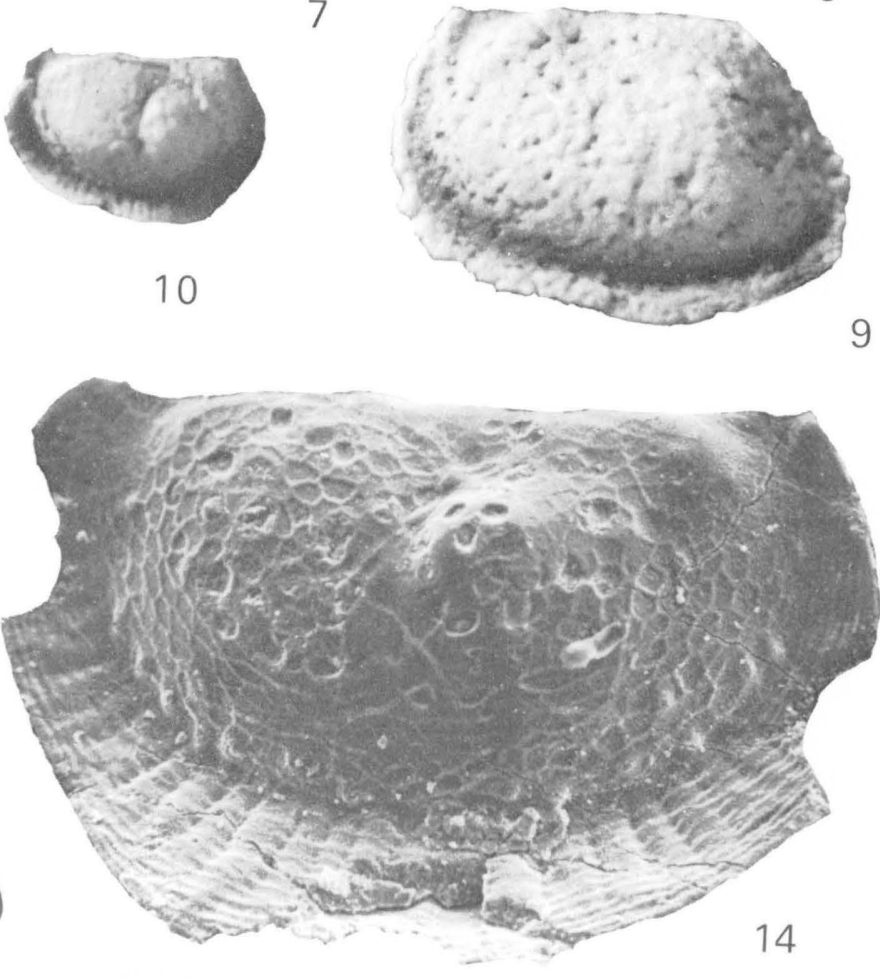

14

HESPERIDELLA?, DICRANELLA, DICRANELLA?, PLATYBOLBINA (RIMABOLBINA), APATOCHILINA, CYSTOMATOCHILINA, EURYCHILINA 


\section{PLATE 10}

[Figures 12-15 are scanning electron micrographs]

Figure 1. Macronotella? sp. (p. H49).

Left valve, figured specimen, USNM 271042, from the Curdsville Limestone Member of the Lexington Limestone, USGS colln. 5083-CO. $\times 30$.

2. Saccelatia sp. (p. H51).

Right valve, figured specimen, USNM 271043, from the Curdsville Limestone Member of the Lexington Limestone, USGS colln. $5083-\mathrm{CO} . \times 30$.

3-5. Hyperchilarina ovata Harris, 1957 (p. H51).

Ventral, right-lateral and left-lateral views of carapace, holotype, MCZ 4511, from the Tulip Creek Formation, Zone 31, U.S. Highway 77 section, Oklahoma. $\times 30$.

6. Oepikella sp. (p. H49).

Right valve, figured specimen, USNM 271044, from the Curdsville Limestone Member of the Lexington Limestone, USGS colln. $5083-$ CO. $\times 30$.

7. "Aparchites" sp. (p. H49).

Right valve, figured specimen, USNM 271045, from the Curdsville Limestone Member of the Lexington Limestone, USGS colln. 5083-CO. $\times 30$.

8-15. Brevidorsa strodescreekensis n. sp. (p. H50).

8, 9. Ventral and left-lateral views of carapace, holotype, USNM 240051, from the Strodes Creek Member of the Lexington Limestone, USGS colln. 7318-CO. $\times 30$.

10, 11. Left-lateral and right-lateral views of carapace, paratype, USNM 240053, from the Strodes Creek Member of the Lexington Limestone, USGS colln. 7318-CO. $\times 30$.

12. Lateroventral view $\left(45^{\circ}\right.$ tilt) of holotype, showing pillar structures on left valve. $\times 50$.

13. Right-lateral $\left(0^{\circ}\right.$ tilt) view of carapace, paratype, USNM 240052, from the Strodes Creek Member of the Lexington Limestone, USGS colln. $7318-\mathrm{CO} . \times 50$.

14. Posteroventral view $\left(0^{\circ}\right.$ tilt) of paratype, USNM 240052, showing details of punctae. $\times 200$.

15. Posteroventral view $\left(70^{\circ}\right.$ tilt) of marginal region of holotype, showing details of pillar structures on left valve. $\times 200$. 


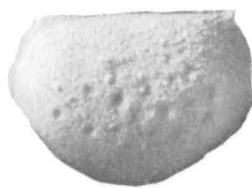

1

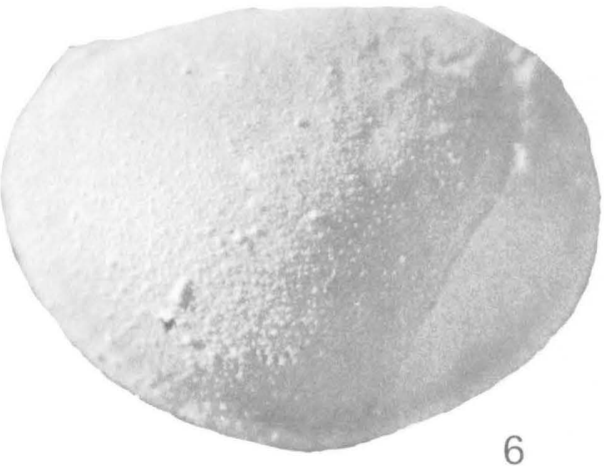

6
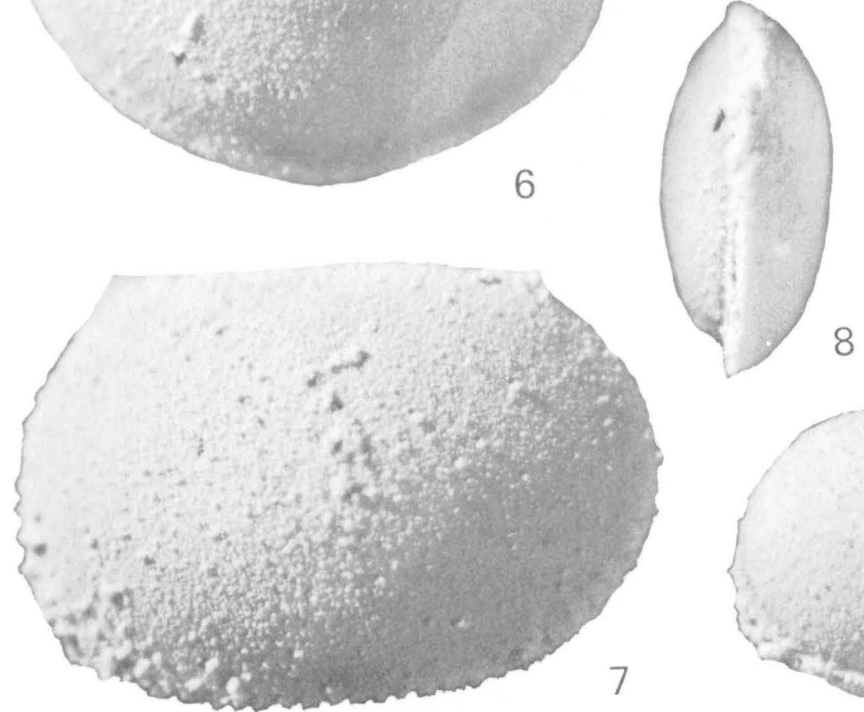

3

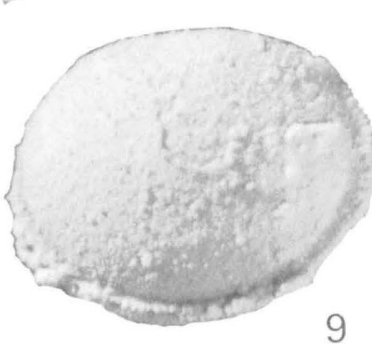

9

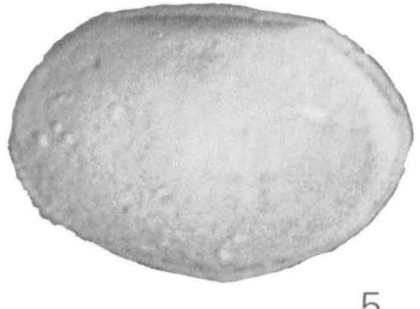

5

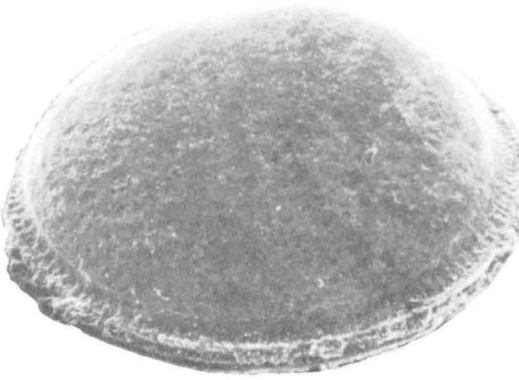

12

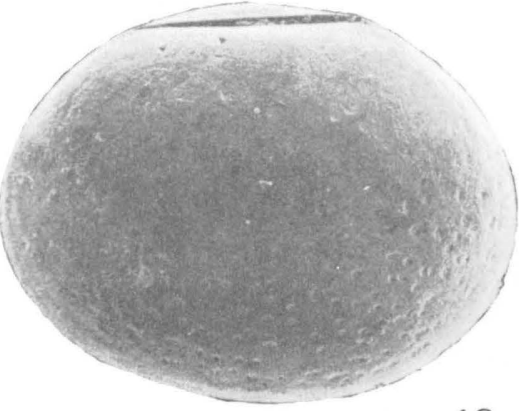

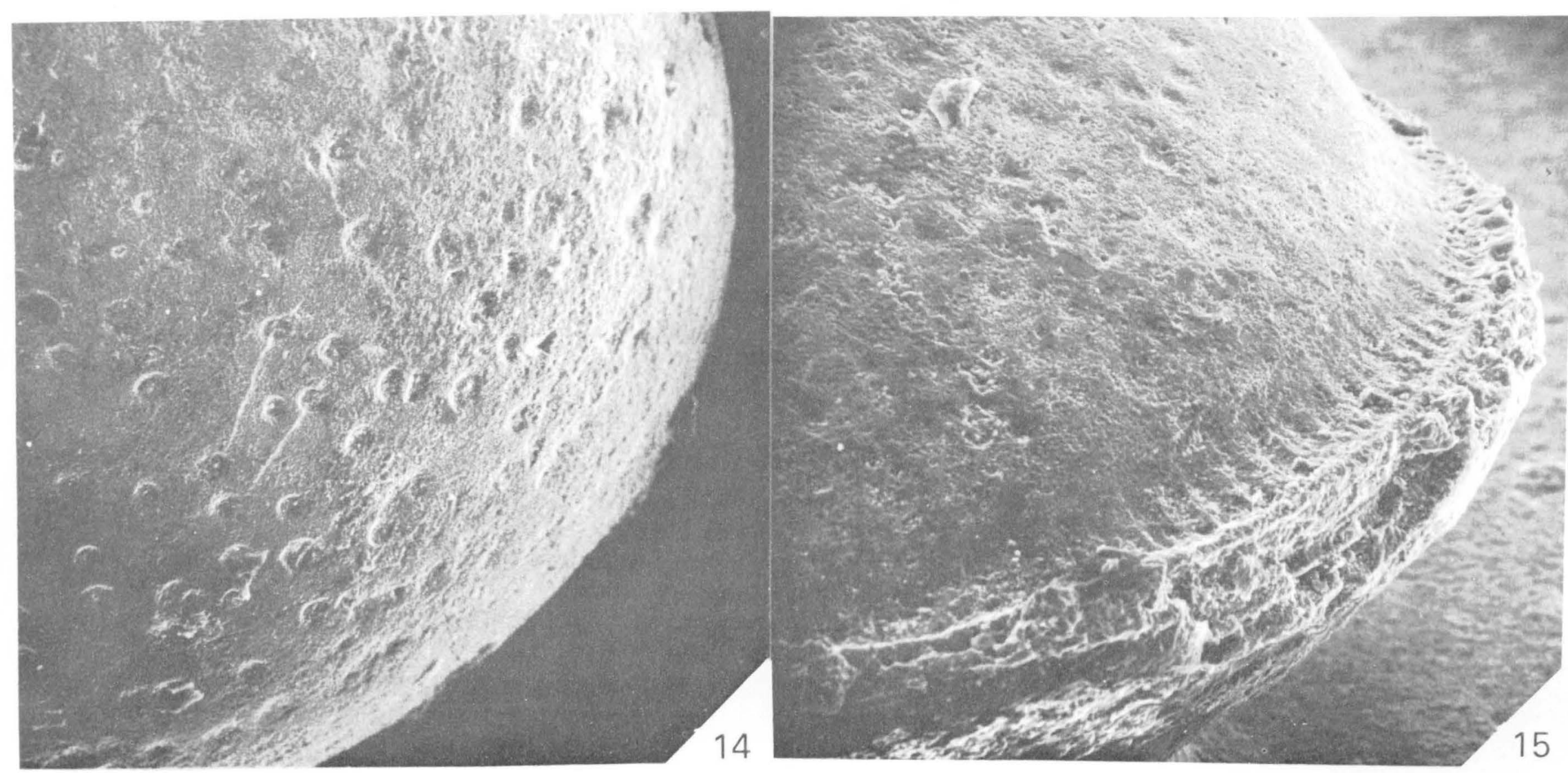

MACRONOTELLA?, SACCELATIA, HYPERCHILARINA, OEPIKELLA, "APARCHITES ," BREVIDORSA 


\section{PLATE 11}

[Figure 9 is a scanning electron micrograph]

Figures 1-4. Leperditella? perplexa n. sp. (p. H53).

1-3. Right-lateral, left-lateral, and dorsal views of carapace, holotype, USNM 271046, from the Millersburg Member of the Lexington Limestone, USGS colln. 7043-CO. $\times 30$.

4. Right valve, paratype, USNM 240045, from the Millersburg Member of the Lexington Limestone, USGS colln. 7039-CO. $\times 30$.

5, 6. Anisocyamus excavatus (Harris, 1957) (p. H52).

Right-lateral and left-lateral views of holotype, MCZ 4595, from the Tulip Creek Formation, Oklahoma Highway 99 section, Oklahoma. $\times 30$

7-9. Anisocyamus? sp. (p. H52).

7. Right valve, figured specimen, USNM 271047, from the Strodes Creek Member of the Lexington Limestone, USGS colln. $7312-$ CO. $\times 30$.

8. Corroded right valve, figured specimen, USNM 240018, from the Clays Ferry Formation, USGS colln. 7459-CO. $\times 30$.

9. Lateral $\left(10^{\circ}\right.$ tilt) view of figured specimen, USNM 240018 , showing posterior ridge. $\times 50$.

10-14. Leperditella sp. aff. L. tumida (Ulrich, 1892) (p. H52).

10-12. Right-lateral, left-lateral and dorsal views of a carapace, figured specimen, USNM 271048, from the Millersburg Member of the Lexington Limestone, USGS colln. 7041-CO. $\times 30$.

13. Right valve, figured specimen, USNM 271049, from the Clays Ferry Formation, USGS colln. D1170-CO. $\times 30$.

14. Left valve, figured specimen, USNM 271050 , from the Clays Ferry Formation, USGS colln. D1171-CO. $\times 30$.

15, 16. Leperditella? canalis Ulrich, 1894 (p. H54).

Ventral and lateral views of right valve, holotype, USNM 41304, from the "lower limestone of the Trenton formation," Minneapolis, Minn., according to old USNM label. $\times 30$.

17. Leperditella? sp. cf. L.? canalis Ulrich, 1894 (p. H53).

Right? valve, figured specimen, USNM 271051, from the Strodes Creek Member of the Lexington Limestone, USGS colln. $7312-$ CO. $\times 30$.

18, 19. Leperditella tumida (Ulrich, 1892) (p. H52).

Right valves, syntypes, USNM 41310, from the upper part of the High Bridge Group, High Bridge, Ky. $\times 30$. 
GEOLOGICAL SURVEY
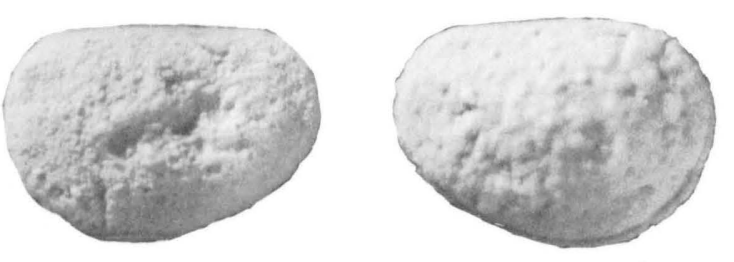

1

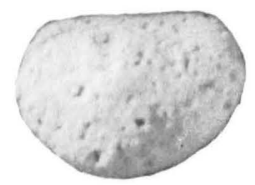

2
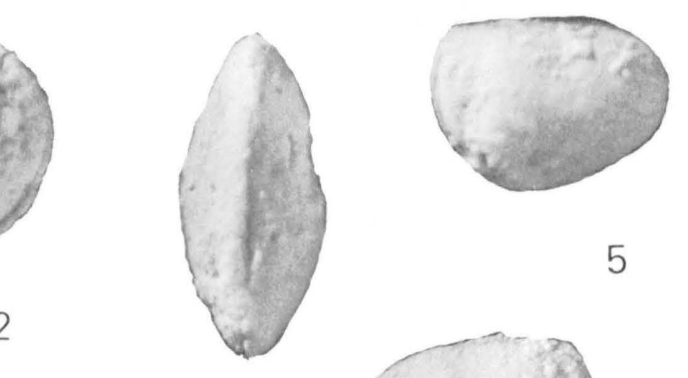

5
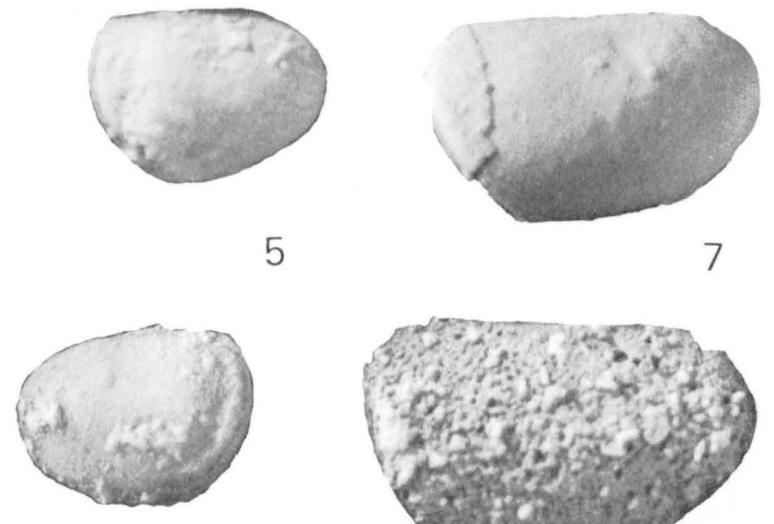

6

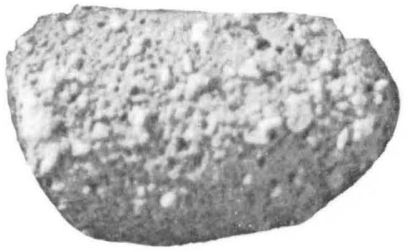

8

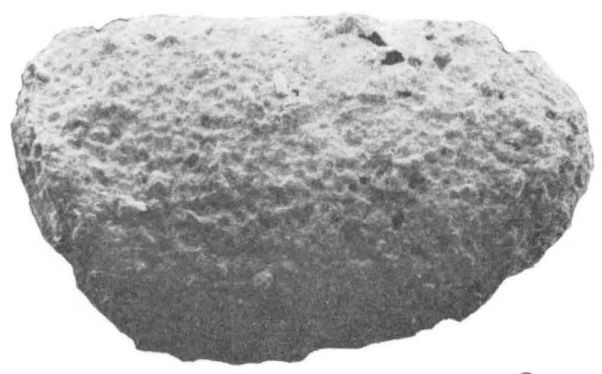

9

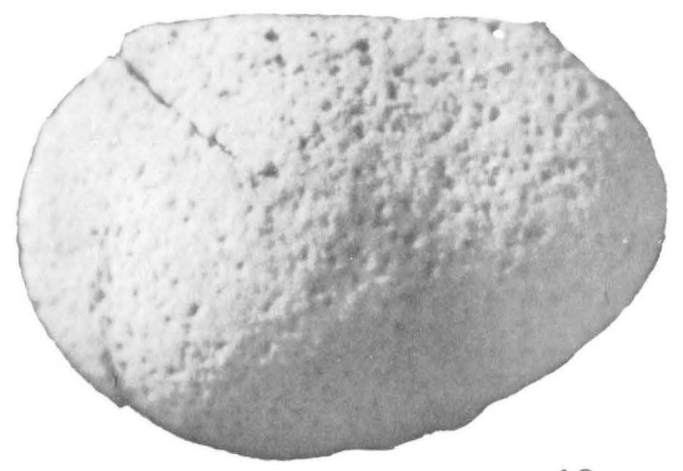

18

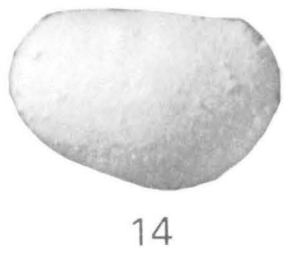

17

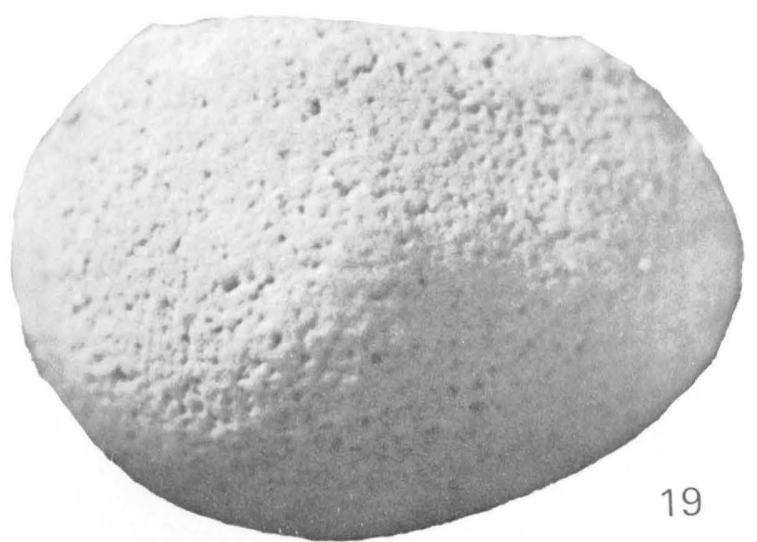

LEPERDITELLA?, ANISOCYAMUS, ANISOCYAMUS?, AND LEPERDITELLA 


\section{PLATE 12}

[Figures 9, 10, and 16 are scanning electron micrographs]

Figure 1. Byrsolopsina? sp. (p. H54).

Lateral view of one valve, figured specimen, USNM, 240015, from the Curdsville Limestone Member of the Lexington Limestone, USGS colln. 5899-CO. $\times 30$.

2-10. Easchmidtella sinuidorsata n. sp. (p. H56).

2, 3. Left-lateral and dorsal views of carapace, holotype, USNM 240049, from the Strodes Creek Member of the Lexington Limestone, USGS colln. 7312-CO. × 30 .

4, 5. Right-lateral and left-lateral views of carapace, paratype, USNM 240050 , from the Strodes Creek Member of the Lexington Limestone, USGS colln. 7312-CO. $\times 30$.

6, 7. Left-lateral and right-lateral views of a more elongate carapace, paratype, USNM 240050a, from the Strodes Creek Member of the Lexington Limestone, USGS colln. 7312-CO. $\times 30$.

8. Right valve, paratype, USNM 271052, from the Strodes Creek Member of the Lexington Limestone, USGS colln. 7325-CO. $\times 30$.

9, 10. Dorsolateral (approximately $25^{\circ}$ tilt) and lateroventral (approximately $25^{\circ}$ tilt) views of holotype. $\times 100$.

11-16. Schmidtella brevis Ulrich, 1894 (p. H55).

11. Left? valve, hypotype, USNM 240025, from the Millersburg Member of the Lexington Limestone, USGS colln. 7455-CO. $\times 30$

12, 15. Lateral and internal views of valve, hypotype, USNM 271053, from the Clays Ferry Formation, USGS colln. $7471-\mathrm{CO}$. $\times 30$.

13. Left? valve, holotype, USNM 41299, from the lower part of the Decorah Shale near Fountain, Minn. $\times 30$.

14. Right? valve, hypotype, USNM 271054, from the Clays Ferry Formation, USGS colln. D1171-CO. $\times 30$.

16. Lateral $\left(10^{\circ}\right.$ tilt) view of hypotype, USNM $240025 . \times 100$.

17, 18. Schmidtella umbonata Ulrich, 1894 (p. H55).

17. Left? valve, lectotype, USNM 41301a, from the Ion Dolomite Member of the Decorah Formation, St. Paul, Minn. $\times 30$

18. Left? valve, hypotype, USNM 271055, from the Curdsville Limestone Member of the Lexington Limestone, USGS colln. $5083-$ CO. $\times 30$.

19, 20. Schmidtella crassimarginata Ulrich, 1892 (p. H54).

19. Right? valve, holotype, USNM 41295, from the Platteville Formation at Mineral Point, Wis. $\times 30$

20. Interior of left valve, paratype, USNM 41295a, from the Platteville Formation at Mineral Point, Wis. $\times 30$. 


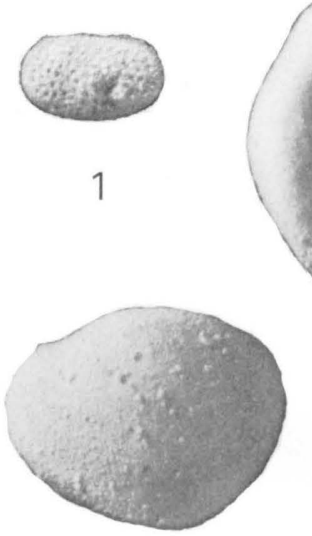

2

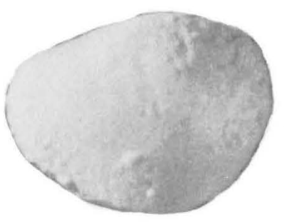

6

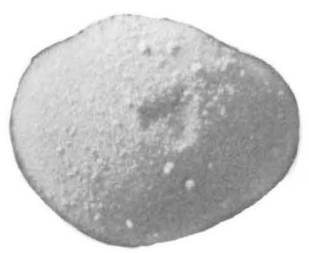

8
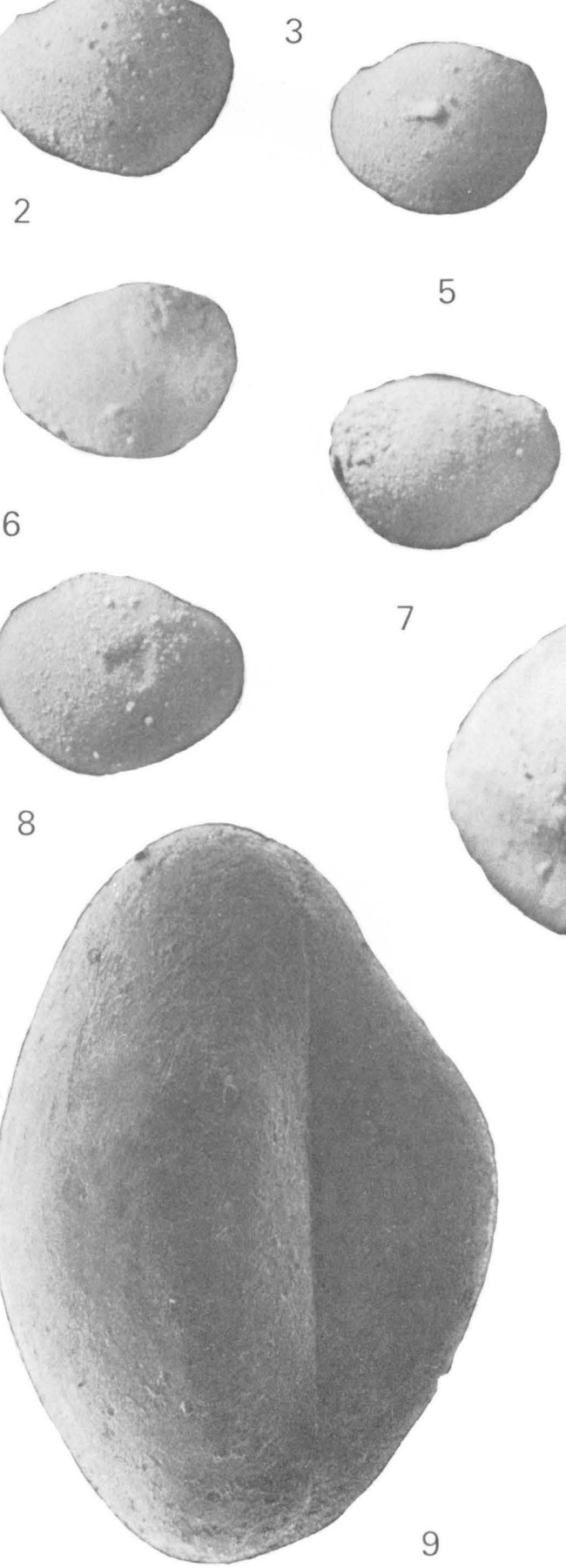

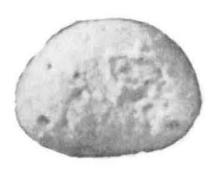

11
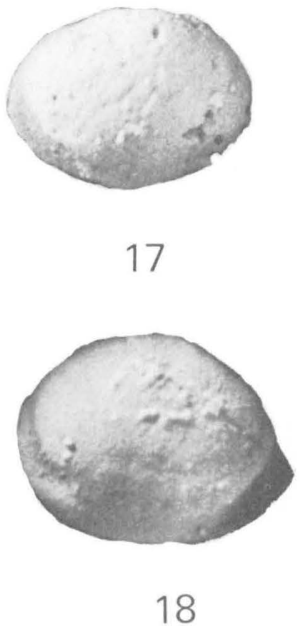

18
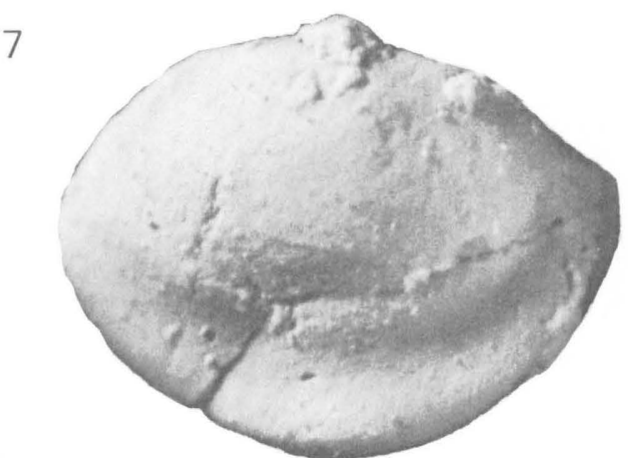

19

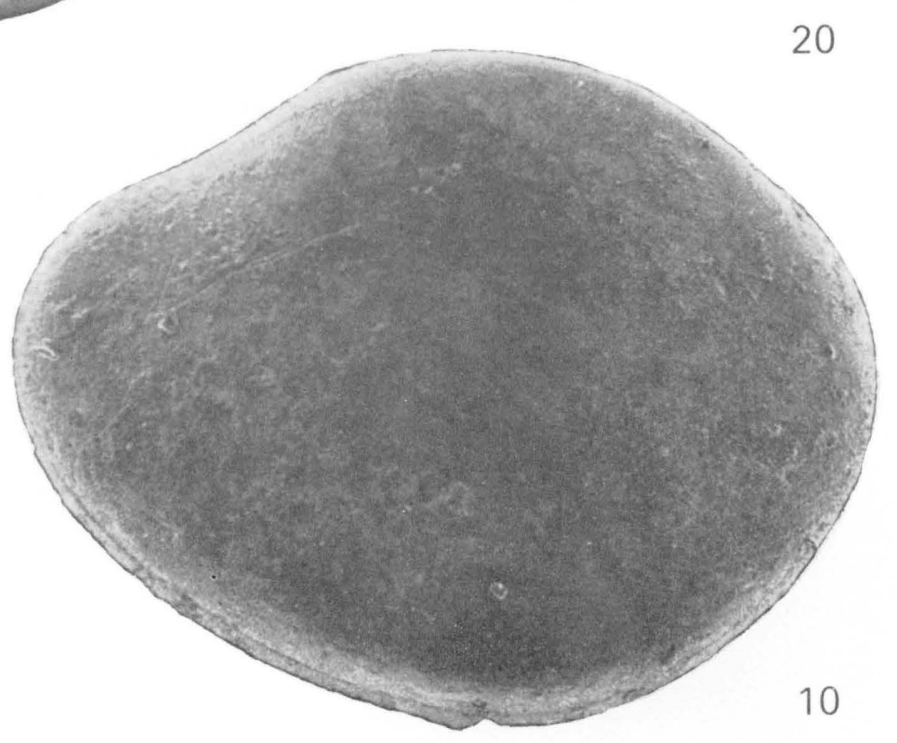

BYRSOLOPSINA?, EASCHMIDTELLA, AND SCHMIDTELLA
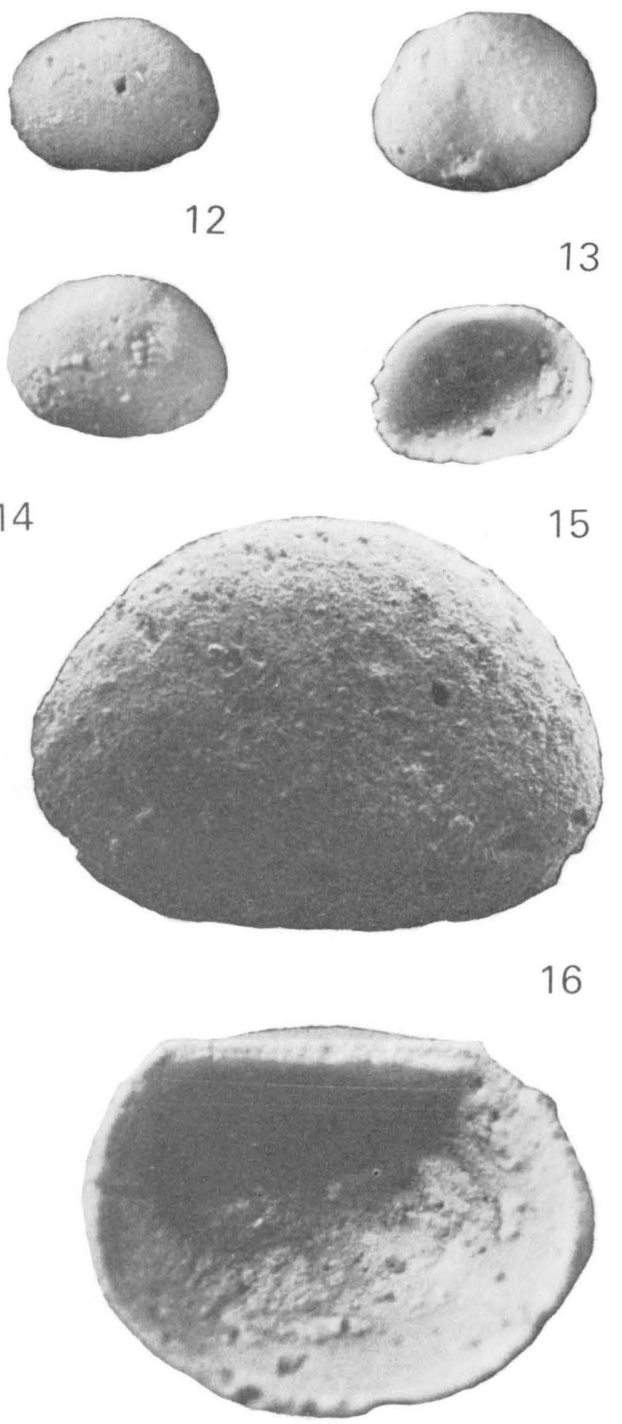


\section{PLATE 13}

[All figures are scanning electron micrographs]

Figures 1, 4. Laccoprimitia rudis (Ulrich, 1890) (p. H58).

1. Interior view $\left(35^{\circ}\right.$ tilt) of adult right valve, hypotype, USNM 240011 , showing straight hingeline, from the Clays Ferry Formation, USGS colln. 7468-CO. $\times 100$.

4. Lateroventral view ( $45^{\circ}$ tilt) of adult left valve, hypotype, USNM 240010 , from the Clays Ferry Formation, USGS colln. $7468-$ CO. $\times 100$.

2, 3, 5, 6. Laccoprimitia cryptomorphologica n. sp. (p. H59).

2. Interior view $\left(0^{\circ}\right.$ tilt) of adult right valve, paratype, USNM 239996, showing hingeline, from the Millersburg Member of the Lexington Limestone, USGS colln. 7455-CO. $\times 100$.

3. Lateral ( $10^{\circ}$ tilt) view of a juvenile left valve, paratype, USNM 239998 , from the Millersburg Member of the Lexington Limestone, USGS colln. 7455-CO. $\times 100$.

5 , 6. Oblique posteroventral $\left(45^{\circ}\right.$ tilt $)$ and lateral $\left(10^{\circ}\right.$ tilt $)$ views of holotype, USNM 239995 , from the Millersburg Member of the Lexington Limestone, USGS colln. 7455-CO. $\times 100$.

7, 8. Laccoprimitia claysferryensis n. sp. (p. H60).

7. Lateral ( $10^{\circ}$ tilt) view of left valve, paratype, USNM 240007, from the Clays Ferry Formation, USGS colln. D1171-CO. $\times 100$.

8. Oblique posteroventral (approximately $60^{\circ}$ tilt) view of left valve, paratype, USNM 240008 , from the Clays Ferry Formation, USGS colln. D1170-CO. × 200. 


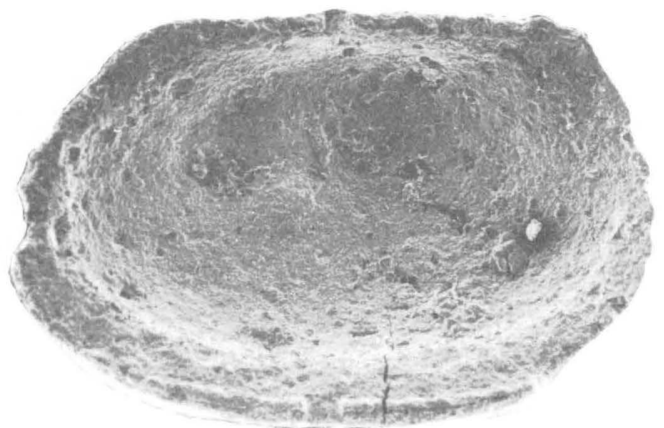

1
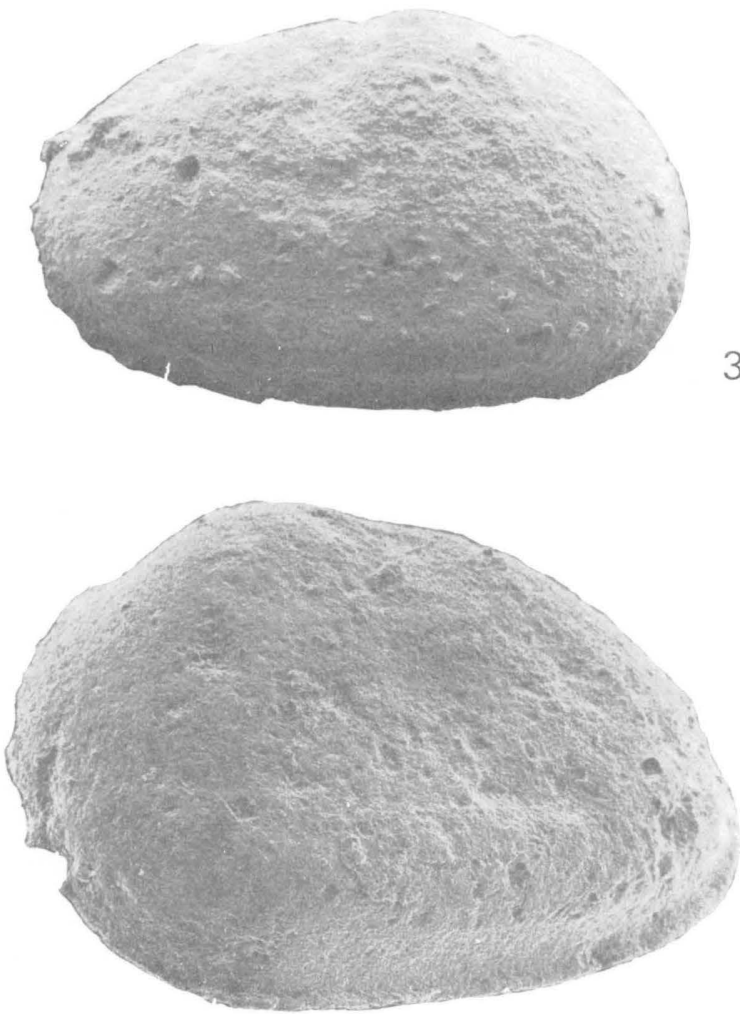

5

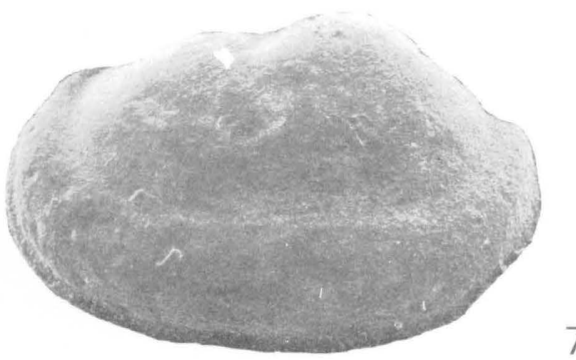

3

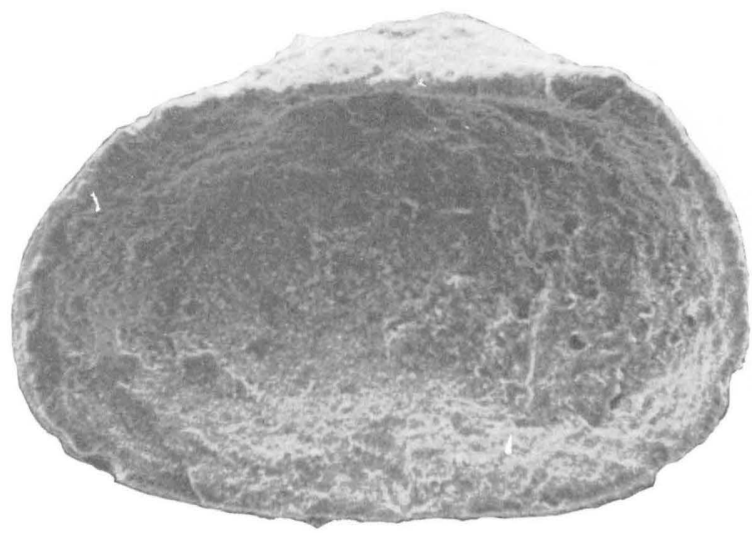

2

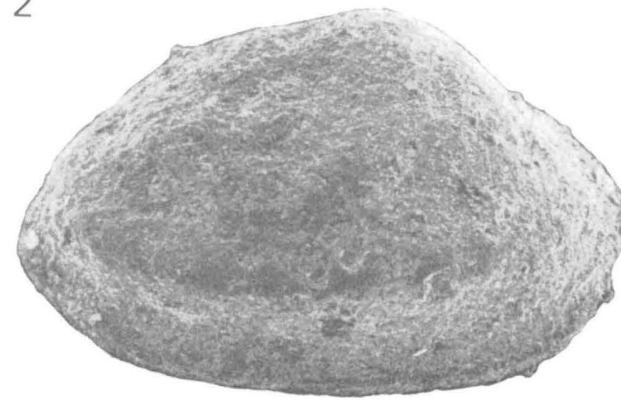

4

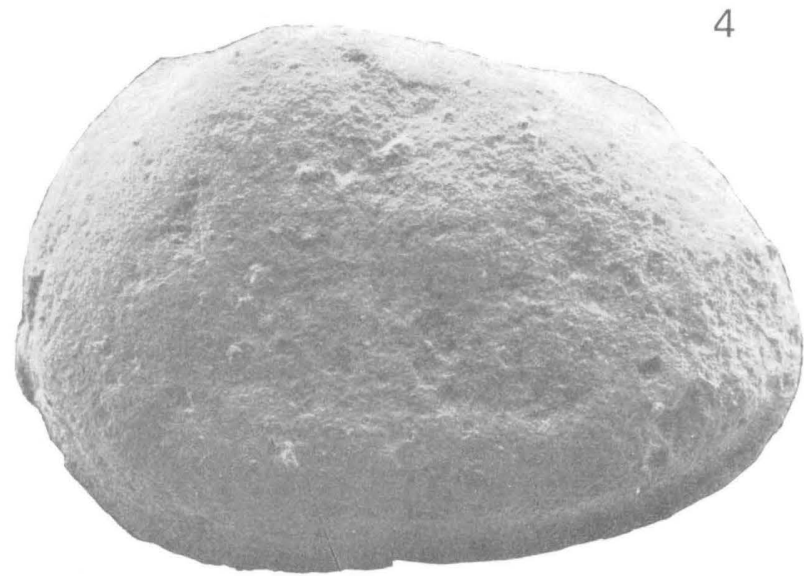

6

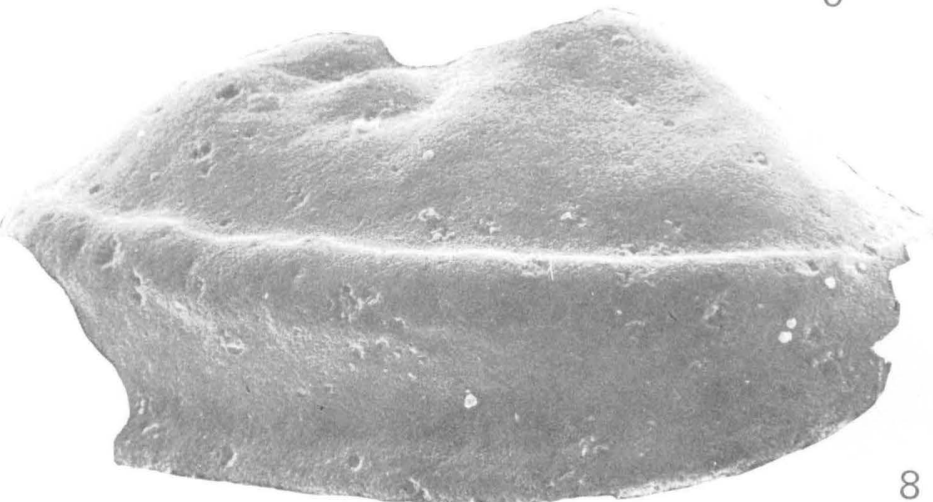

LACCOPRIMITIA 


\section{PLATE 14}

[Figures 36, 40, 41 are scanning electron micrographs]

FIGURES 1-5. Milleratia perminima (Ulrich, 1890) (p. H61).

1, 2. Left valves, syntypes, USNM 41436, from the Point Pleasant Tongue of the Clays Ferry Formation, mouth of Licking River, Covington, Ky. $\times 30$.

3. Right valve, hypotype, USNM 271056, from slab numbered USNM 41500 from the Point Pleasant Tongue of the Clays Ferry Formation, Banklick Creek, near Covington, Ky. $\times 30$.

4, 5. Right valves, hypotypes, USNM 271057, 271058, from the Point Pleasant Tongue of the Clays Ferry Formation, Moffett Road section, De Mossville Quadrangle, Kentucky, USGS colln. 8406-CO. $\times 30$.

6. Milleratia cincinnatiensis (Miller, 1875) (p. H57).

Left valve, syntype, UC 8789, Upper Ordovician, Indiana or Ohio. $\times 30$.

7. Laccoprimitia shideleri (Levinson, 1951) (p. H57).

Left valve, holotype, USNM 116364, from the Elkhorn Formation of the Richmond Group, one-quarter mile north of Fairhaven, Ohio. $\times 30$.

8. Laccoprimitia centralis (Ulrich, 1890) (p. H57).

Left valve, holotype, USNM 41337, from the Point Pleasant Tongue of the Clays Ferry Formation, Ohio River bed, Covington, Ky. $\times 30$.

9-19. Laccoprimitia rudis (Ulrich, 1890) (p. H58).

9. Right valve, holotype, USNM 41345, from the Kope Formation, Covington, Ky. $\times 30$.

10-13. Left-lateral, ventral, right-lateral and dorsal views of a carapace, hypotype, USNM 271059, from the Clays Ferry Formation, USGS colln. 7468-CO. $\times 30$.

14, 15. Left valves, hypotypes, USNM 271060, 240010, from the Clays Ferry Formation, USGS colln. 7468-CO. $\times 30$.

16. Right valve, hypotype, USNM 240012, from the Clays Ferry Formation, USGS colln. 7468-CO. $\times 30$.

17. Juvenile left valve, hypotype, USNM 271061, from the Clays Ferry Formation, USGS colln. 7468-CO. $\times 30$.

18, 19. Right valves, hypotypes, USNM 271062, 271063, from the Clays Ferry Formation, USGS colln. 7468-CO. $\times 30$.

20-27. Laccoprimitia cryptomorphologica n. sp. (p. H59).

20. Juvenile left valve, paratype, USNM 239998, from the Millersburg Member of the Lexington Limestone, USGS colln. $7455-$ CO. $\times 30$.

21-23. Dorsal, left-lateral and right-lateral views of carapace, paratype, USNM 271064, from the Millersburg Member of the Lexington Limestone, USGS colln. 7455-CO. × 30 .

24, 25. Exterior and interior views of right valve, paratype, USNM 271065, from the Clays Ferry Formation, USGS colln. $7471-$ CO. $\times 30$.

26. Right valve, holotype, USNM 239995, from the Millersburg Member of the Lexington Limestone, USGS colln. 7455-CO. × 30 .

27. Left valve, paratype, USNM 239997, from the Millersburg Member of the Lexington Limestone, USGS colln. 7455-CO. $\times$ 30.

28-32. Laccoprimitia claysferryensis n. sp. (p. H60).

28. Right valve, holotype, USNM 240006, from the Clays Ferry Formation, USGS colln. D1169-CO. $\times 30$.

29, 30. Right valves, paratypes, USNM 240009, 240008, from the Clays Ferry Formation, USGS colln. D1170-CO. $\times 30$

31. Right valve, paratype, USNM 271066, from the Clays Ferry Formation, USGS colln. D1171-CO. $\times 30$.

32. Right valve, paratype, USNM 240007, from the Clays Ferry Formation, USGS colln. D1169-CO. $\times 30$.

33. Ectoprimitia? sp. (p. H63).

Left valve, figured specimen, USNM 271068, from the Curdsville Limestone Member of the Lexington Limestone, USGS colln. $5083-$ CO. $\times 30$.

34-36. Ectoprimitia? sp. cf. E.? diminucarina Kraft, 1962 (p. H62).

34. Right valve, figured specimen, USNM, 240024, from the Strodes Creek Member of the Lexington Limestone, USGS colln. $7312-$ CO. $\times 30$.

35. Left valve, figured specimen, USNM 271069, from the Devils Hollow Member of the Lexington Limestone, USGS colln. D1207-CO. $\times 30$.

36. Lateral $\left(10^{\circ}\right.$ tilt) view of figured speciman USNM $240024 . \times 130$.

37-41. Uninodobolba franklinensis n. gen., n. sp. (p. H62).

37. Left valve, paratype, USNM 271070, from the Strodes Creek Member of the Lexington Limestone, USGS colln. 7318-CO. $\times 30$.

38. Left valve, holotype, USNM 240037, from the Devils Hollow Member of the Lexington Limestone, USGS colln. D1207-CO. $\times 30$.

39. Right valve, paratype, USNM 271071, from the Strodes Creek Member of the Lexington Limestone, USGS colln. 7318-CO. $\times 30$.

40,41 . Lateroventral $\left(52^{\circ}\right.$ tilt $)$ and lateral $\left(10^{\circ}\right.$ tilt $)$ views of the holotype. $\times 100$. 
GEOLOGICAL SURVEY

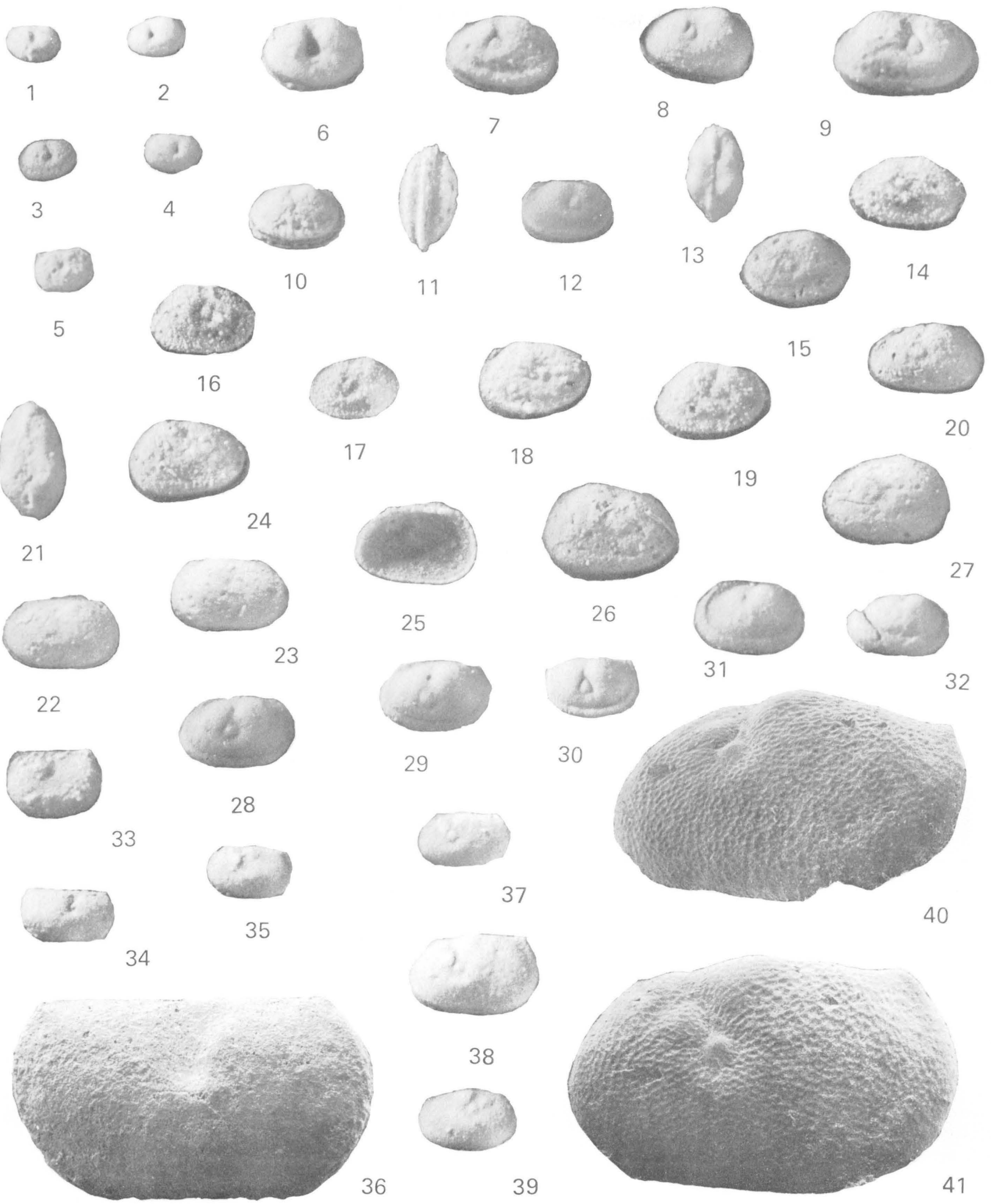

MILLERATIA, LACCOPRIMITIA, ECTOPRIMITIA?, UNINODOBOLBA 


\section{PLATE 15}

[Figures 7-9, 17, 18, and 20 are scanning electron micrographs]

Figures 1-9. Ningulella sp. (p. H64).

1. Right valve, figured specimen, USNM 271072, from the Grier Limestone Member of the Lexington Limestone, USGS colln. 4876 -CO. $\times 30$.

2. Left valve, figured specimen, USNM 271073, from the Logana Member of the Lexington Limestone, USGS colln. D1196-CO. $\times 30$.

3. Right valve, figured specimen, USNM 271074, from the Logana Member of the Lexington Limestone, USGS colln. D1196-CO. $\times 30$.

4-6. Left valves, figured specimens, USNM 271075, 271076, and 240044, from the Logana Member of the Lexington Limestone, USGS colln. D1196-CO. $\times 30$

7-9. Oblique posteroventral $\left(45^{\circ}\right.$ tilt), oblique anteroventral $\left(45^{\circ}\right.$ tilt $)$ and lateral $\left(10^{\circ}\right.$ tilt $)$ views of figured specimen, USNM 240044 , showing posterior node. $\times 100$.

10-18. Ningulella paupera n. sp. (p. H63).

10, 14. Right-lateral and left-lateral views of carapace, paratype, USNM 271077, from the Strodes Creek Member of the Lexington Limestone, USGS colln. 7318-CO. × 30 .

11-13. Dorsal, left-lateral, and ventral views of carapace, holotype, USNM 271078, from the Strodes Creek Member of the Lexington Limestone, USGS colln. 7318-CO. $\times 30$.

15, 16. Left-lateral and dorsal views of paratype, USNM 240043, from the Strodes Creek Member of the Lexington Limestone, USGS colln. 7325-CO. $\times 30$.

17, 18. Left-lateroventral $\left(45^{\circ}\right.$ tilt) and left-lateral $\left(0^{\circ}\right.$ tilt $)$ views of paratype, USNM 240043. $\times 50$.

19, 20. Pseudoprimitiella? sp. (p. H64).

19. Left valve, figured specimen, USNM 240021, from the Clays Ferry Formation, USGS colln. 7471-CO. $\times 30$

20 . Lateral $\left(10^{\circ}\right.$ tilt $)$ view of figured specimen, USNM 240021. $\times 90$. 


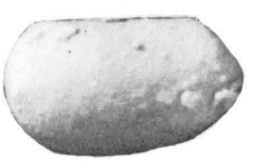

1

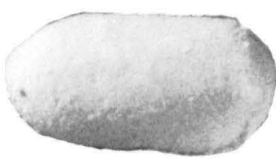

2

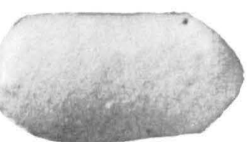

3

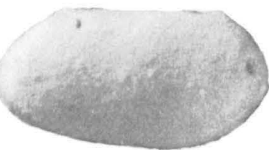

4

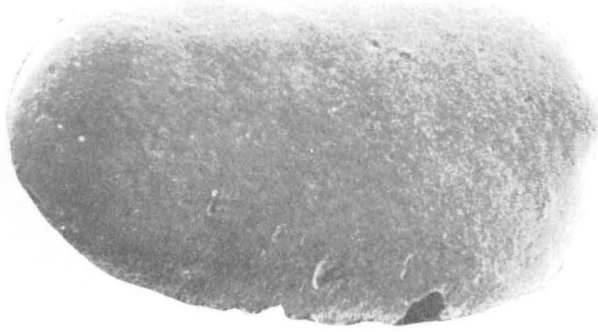

8

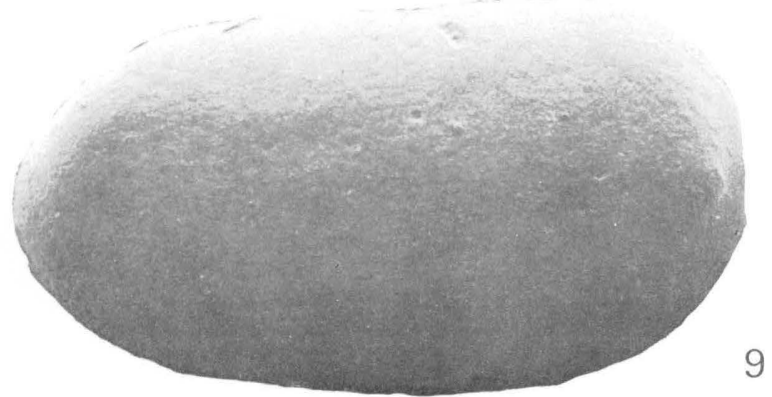

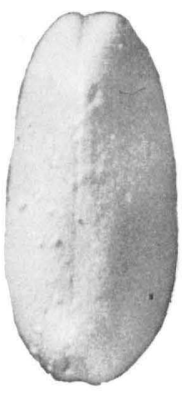

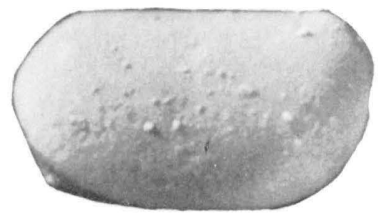

12

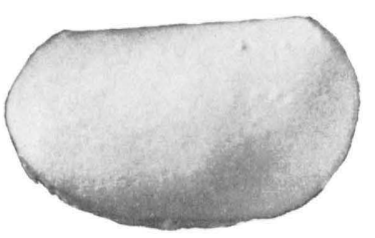

14
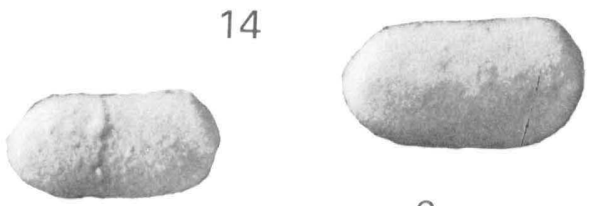

6

5

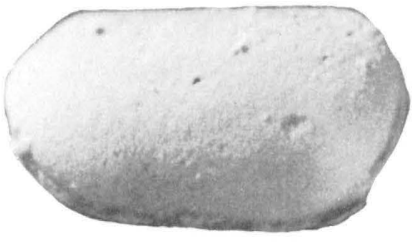

15

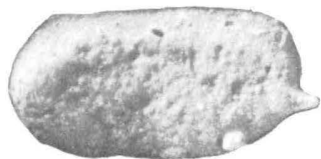

19

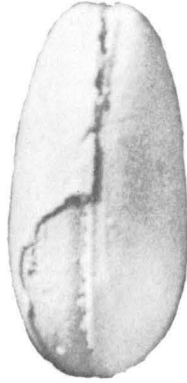

13
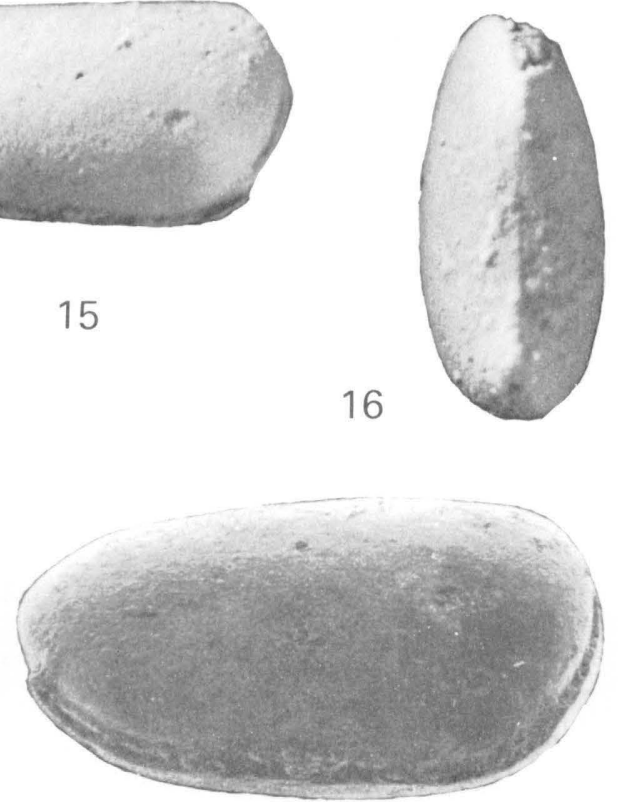

17

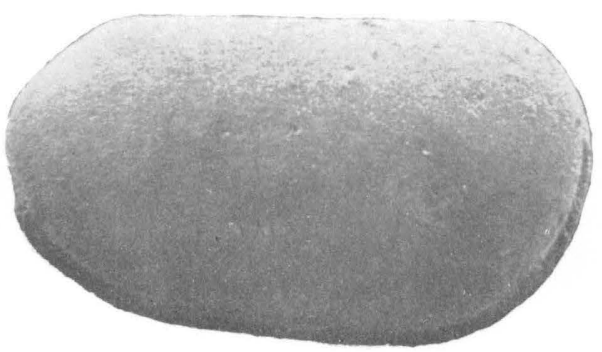

18

NINGULELLA AND PSEUDOPRIMITIELLA? 


\section{PLATE 16}

[Figures 6,8 , and 9 are scanning electron micrographs|

Flit Re: 1. Bolbopisthia sculptilis (Ulrich, 1890) (p: H65).

Broken and exfoliated right valve, holotype, USNM 41362, from the Perryville Limestone Member of the Lexington Limestone, Perryville, Ky. $\times 30$.

2. Bolbopisthia reticulata (Kirk, 1928) (p. H65).

Broken right valve, holotype, YPM 26820, from the Catheys Limestone, Nashville, Tenn. $\times 30$.

3-8. Bolbopisthia sculptilis (Ulrich, 1890) (p. H65).

3. Coarsely silicified right valve, hypotype, USNM 271079, from the Salvisa Bed of the Perryville Limestone Member of the Lexington Limestone, USGS colln. 5015-CO. $\times 30$

4. Broken right valve, hypotype, USNM 240022, from the Salvisa Bed of the Perryville Limestone Member of the Lexington Limestone, USGS colln. 6915-CO. × 30 .

5, 7. Broken silicified right valves, hypotypes, USNM 271080, 271081, from the Salvisa Bed of the Perryville Limestone Member of the Lexington Limestone, USGS colln. 6137-CO. $\times 30$.

6, 8. Lateroventral $\left(45^{\circ}\right.$ tilt) and lateral $\left(10^{\circ}\right.$ tilt $)$ views of hypotype, USNM $240022 . \times 50$.

9. Cystomatochilina reticulotiara n. sp. (p. H46).

Detailed view $\left(45^{\circ}\right.$ tilt $)$ of preadductorial node of holotype, USNM 240027 , showing pitted surface. $\times 500$. 

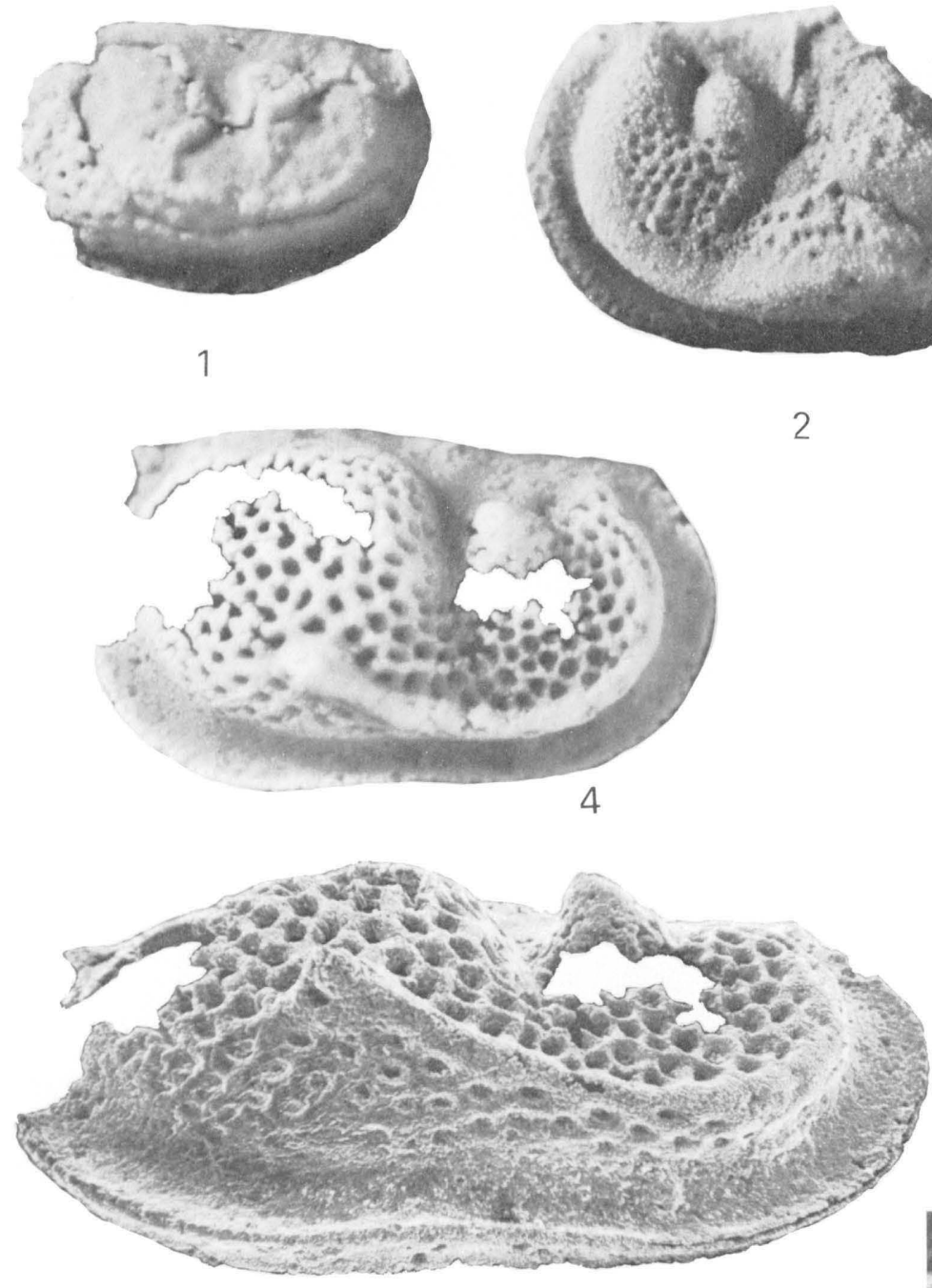

6
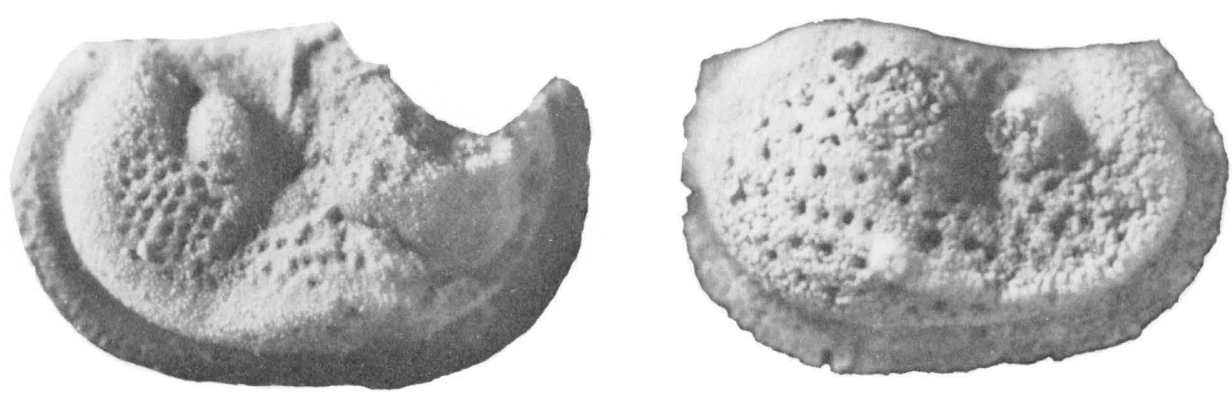

2

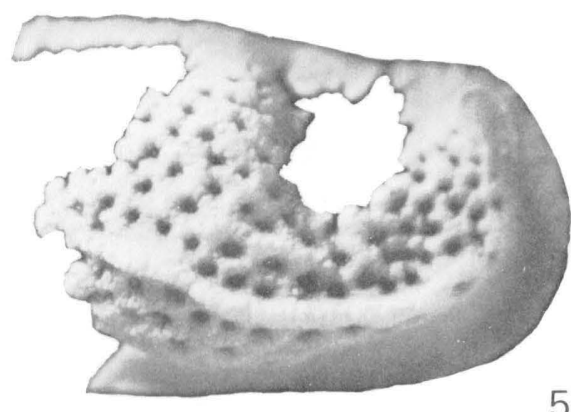

3

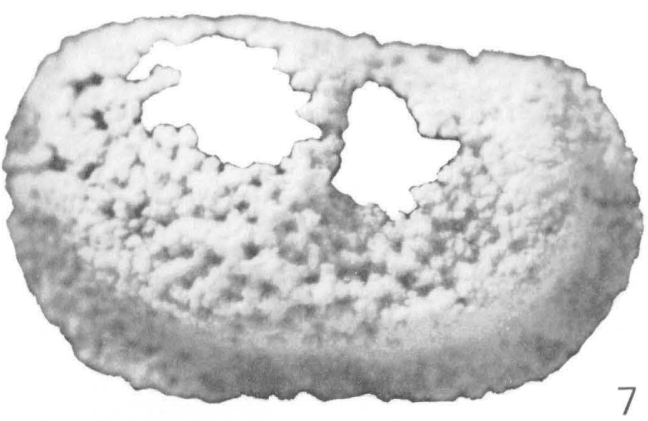

7

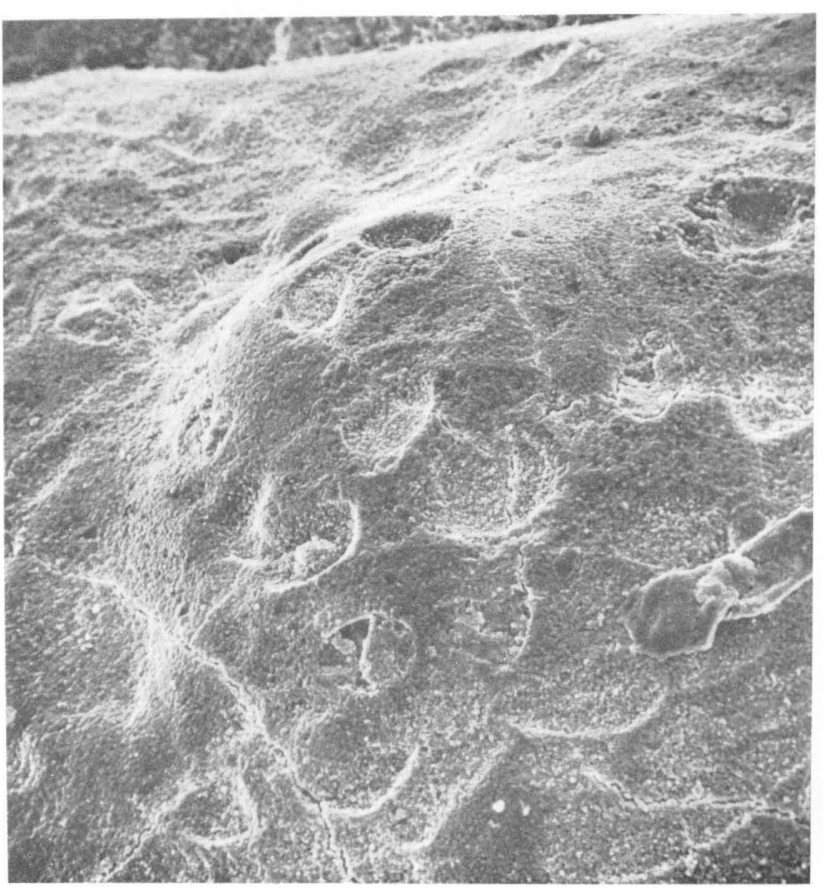

BOLBOPISTHIA AND CYSTOMATOCHILINA 


\section{PLATE 17}

[Figures 23-29 are scanning electron micrographs]

Figures 1-3. Cryptophyllus oboloides (Ulrich and Bassler, 1923) (p. H67).

Lateral views of the three syntypes, USNM 82388, from the Decorah Shale, St. Paul, Minn. $\times 30$.

4-6. Cryptophyllus sp. (p. H67).

Right-lateral, dorsal, and left-lateral views of figured specimen, USNM 271082, from the Curdsville Limestone Member of the Lexington Limestone, USGS colln. 5083-CO. $\times 30$.

7-10. Eridoconcha rugosa (Ulrich and Bassler, 1923) (p. H67).

7, 8. Lateral view of syntypes, USNM 82389, from the Corryville Bed, Maysvillian, Cincinnati, Ohio. $\times 30$.

9, 10. Dorsal and lateral views of carapace, syntype, USNM 82389. $\times 30$.

11. Americoncha marginata (Ulrich, 1890) (p. H67).

Right? valve, holotype, USNM 41364, from the Maysvillian Stage, Cincinnati, Ohio. $\times 30$.

12. Americoncha multiannulata (Levinson, 1951) (p. H67).

Right? valve, holotype, USNM 116365, from the Richmondian Stage, 1/2 mile south of Oxford, Ohio. $\times 30$.

13-29. Americoncha dubia n. sp. (p. H66).

All specimens except figure 23 from the Clays Ferry Formation, USGS colln. 7468-CO.

13. Juvenile left valve, paratype, USNM 271083, one lamella, no retained molts. $\times 30$.

14. Juvenile right valve, paratype, USNM 271084 , two lamellae, one retained molt. $\times 30$.

15. Juvenile right valve, paratype, USNM 271085 , one lamella, no retained molts. $\times 30$.

16. Juvenile right valve, paratype, USNM 271086, two lamellae, one retained molt. $\times 30$.

17. Adult right valve, paratype, USNM 271087 , two lamellae, one retained molt. $\times 30$.

18, 19. Right and left views of carapace, holotype, USNM 240038 , two lamellae, one retained molt. $\times 30$.

20. Elongate adult right valve, paratype, USNM 271088, two lamellae, one retained molt. $\times 30$.

21. Left valve, paratype, USNM 240040 , three lamellae, two retained molts. $\times 30$.

22. Internal $\left(10^{\circ}\right.$ tilt $)$ view of paratype, USNM $240040 . \times 100$.

23. Left valve, paratype, USNM 240042, two lamellae, one retained molt, from the Millersburg Member of the Lexington Limestone, USGS colln. 7454-CO. $\times 30$.

24,25 . Lateral $\left(10^{\circ}\right.$ tilt) and lateroventral $\left(45^{\circ}\right.$ tilt) views of paratype, USNM $240042 . \times 100$.

26,27 . Oblique posterolateral $\left(56^{\circ}\right.$ tilt $)$ and oblique anterior $\left(56^{\circ}\right.$ tilt $)$ views of carapace with two retained molts, unnumbered, specimen lost. $\times 100$.

28 , 29. Lateral $\left(10^{\circ}\right.$ tilt) and lateroventral $\left(56^{\circ}\right.$ tilt) views of right valve with two retained molts, unnumbered, specimen lost. $\times 100$. 


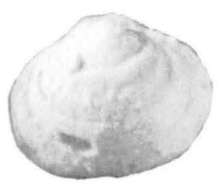

1

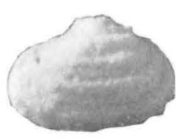

7

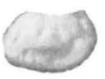

13

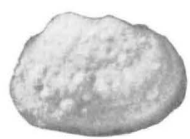

17

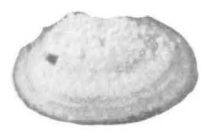

20

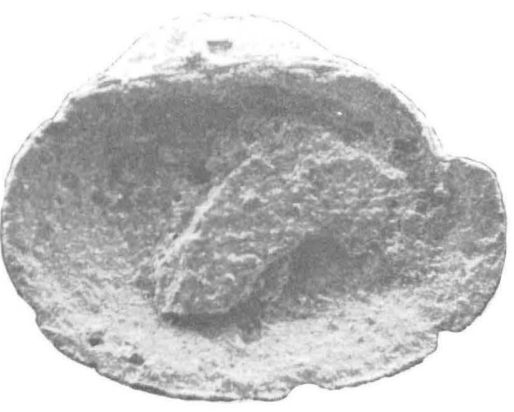

22

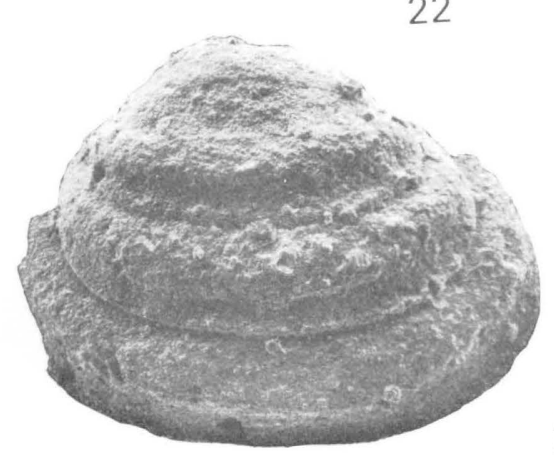

28

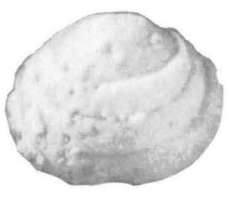

3

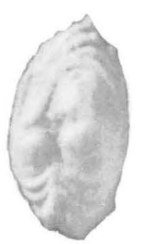

9

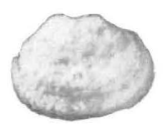

15

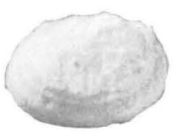

19

16
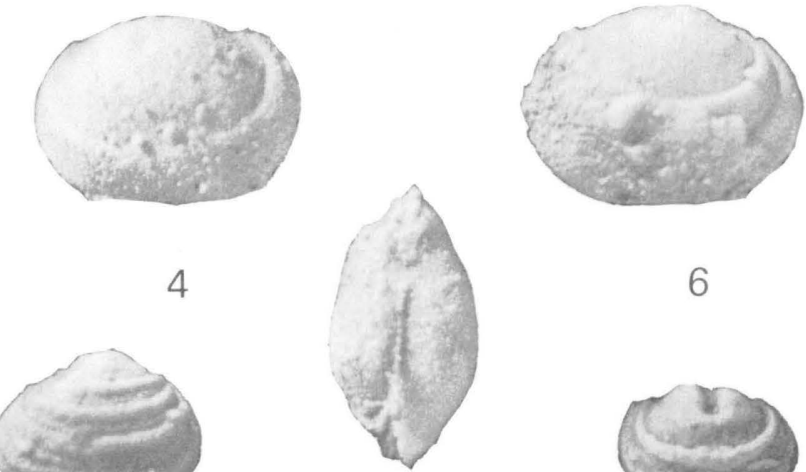

6

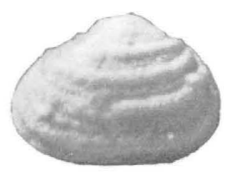

10

5

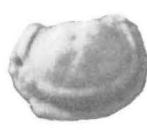

12

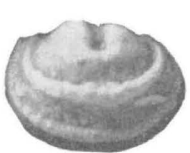

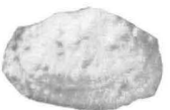

23

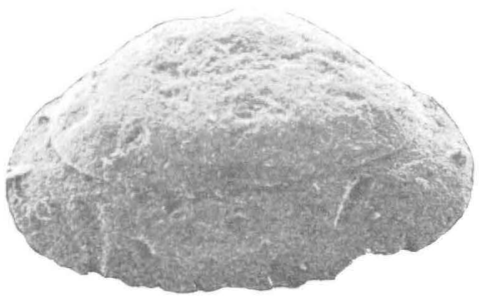

25

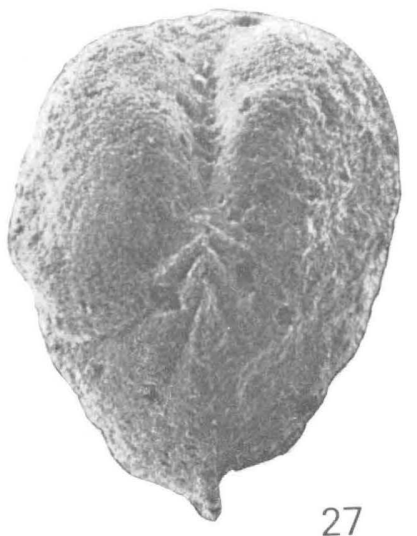

11

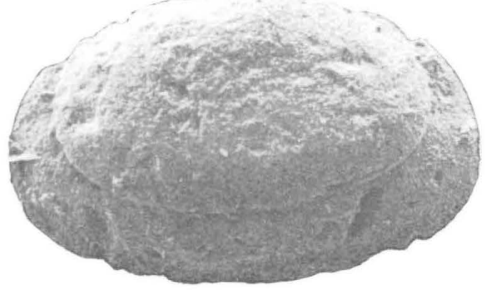

24

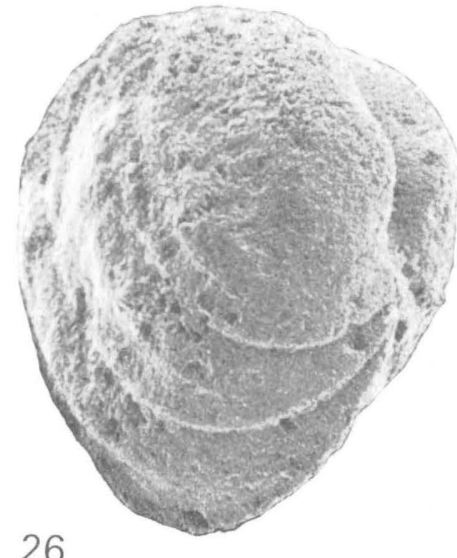

26

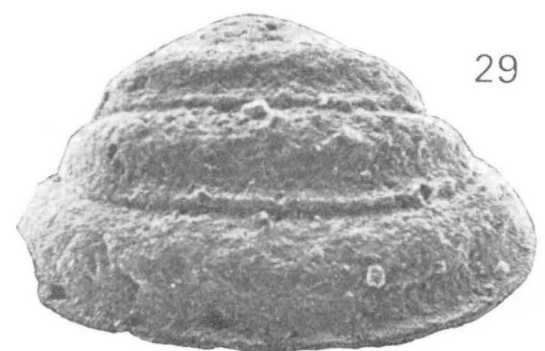

CRYPTOPHYLLUS, ERIDOCONCHA, AND AMERICONCHA 


\section{PLATE 18}

[Figures 17,18 , and 23-25 are scanning electron micrographs]

Figures 1-4. Shenandoia? sp. (p. H70).

1, 2. Left-lateral and dorsal views of a carapace, figured specimen, USNM 271089, from the Strodes Creek Member of the Lexington Limestone, USGS colln. 7312-CO. $\times 30$.

3 , 4. Right-lateral and dorsal views of a carapace, figured specimen, USNM 271090, from the Strodes Creek Member of the Lexington Limestone, USGS colln. 7312-CO. $\times 30$.

5-7. Elliptocyprites sp. (p. H70).

5. Left valve, figured specimen, USNM 240033, from the Strodes Creek Member of the Lexington Limestone, USGS colln. 7318-CO. $\times 30$.

6, 7. Right-lateral and dorsal views of carapace, figured specimen, USNM 240034, from the Strodes Creek Member of the Lexington Limestone, USGS colln. 7312-CO. $\times 30$.

8-18. Phelobythocypris cylindrica (Hall, 1871) (p. H68).

8. Right valve, hypotype, USNM 271091, from the Curdsville Limestone Member of the Lexington Limestone, USGS colln. 5083-CO. $\times 30$.

9, 10. Right-lateral and dorsal views of carapace, hypotype, USNM 271092, from the Strodes Creek Member of the Lexington Limestone, USGS colln. 7312-CO. $\times 30$.

11. Right valve, hypotype, USNM 271093, from the Millersburg Member of the Lexington Limestone, USGS colln. 7454-CO. $\times$ 30 .

12, 13. Internal views of left and right valves, hypotypes, USNM 271094, 271095, from the Clays Ferry Formation, USGS colln. $6945-$ CO. $\times 30$.

14. Left-lateral view of carapace, hypotype, USNM 41795, from the upper third of the Kope Formation, Cincinnati, Ohio. $\times 30$.

15, 16. Right-lateral and dorsal views of carapace, hypotype, USNM 271096, from the Strodes Creek Member of the Lexington Limestone, USGS colln. 7312-CO. $\times 30$.

17 , 18. Lateroventral $\left(45^{\circ}\right.$ tilt $)$ and lateral $\left(10^{\circ}\right.$ tilt) views of carapace, hypotype, USNM 240031 , from the Tanglewood Limestone Member of the Lexington Limestone, USGS colln. 7467-CO. $\times 50$.

19-25. Silenis kentuckyensis n. sp. (p. H70).

19, 20. Dorsal and left-lateral views of holotype, USNM 240056, from the Strodes Creek Member of the Lexington Limestone, USGS colln. 7318-CO. $\times 30$.

21, 22. Left-lateral and right-lateral views of paratype, USNM 240057, from the Strodes Creek Member of the Lexington Limestone, USGS colln. 7318-CO. $\times 30$.

23. Dorsal $\left(56^{\circ}\right.$ tilt $)$ view of paratype, USNM $240057 . \times 85$.

24,25 . Lateroventral $\left(70^{\circ}\right.$ tilt $)$ and lateral $\left(10^{\circ}\right.$ tilt $)$ views of holotype, USNM $240056 . \times 100$. 

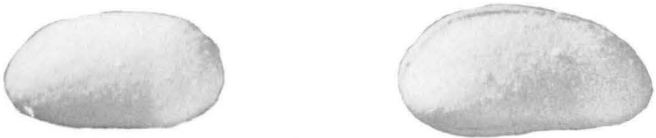

4
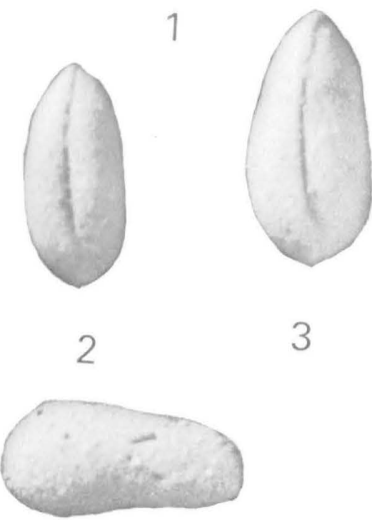

11
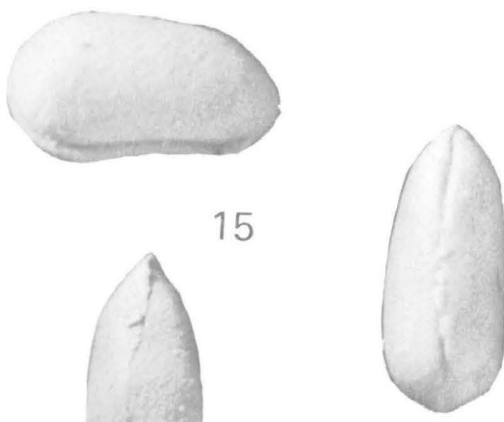

16

19

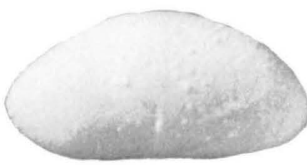

20

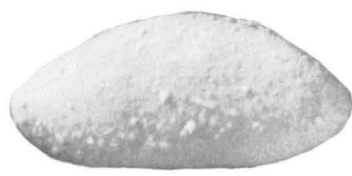

21
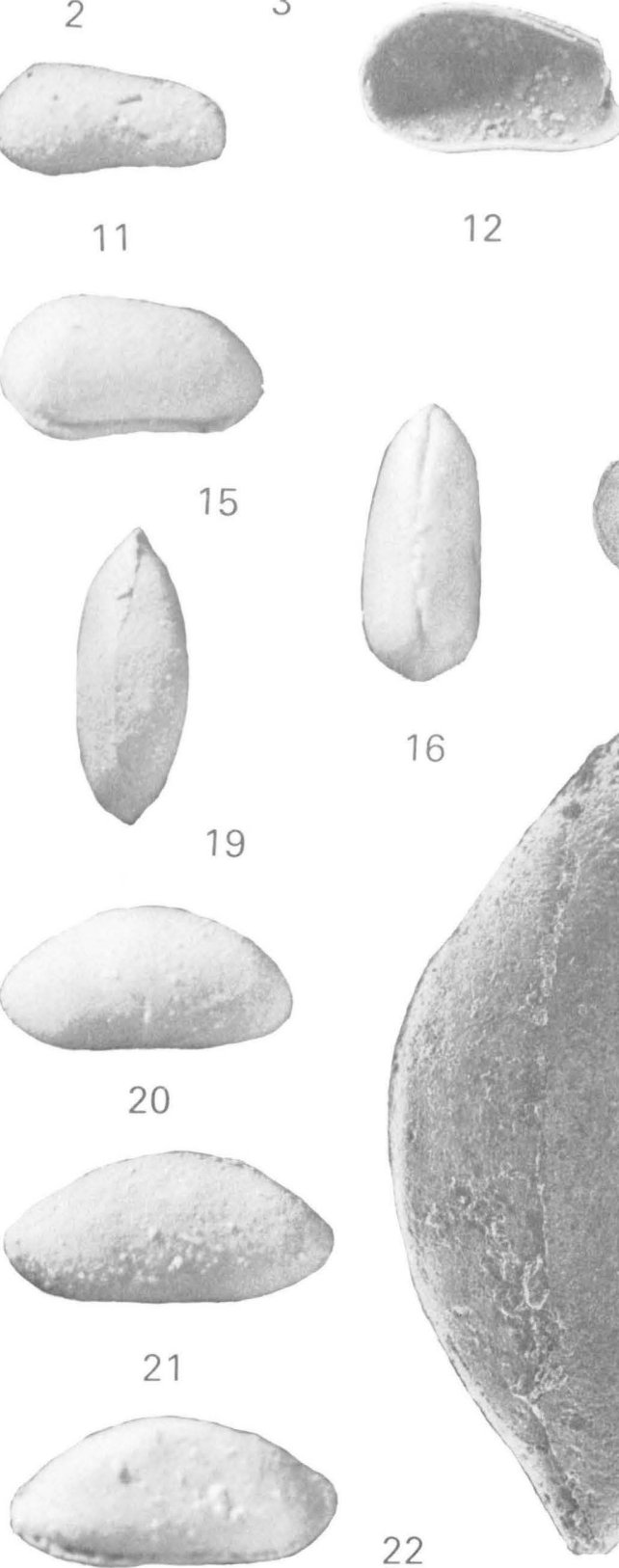

12

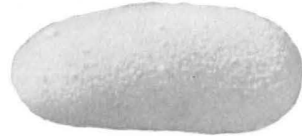

5

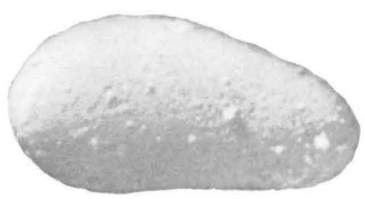

8

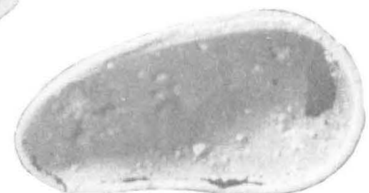

13
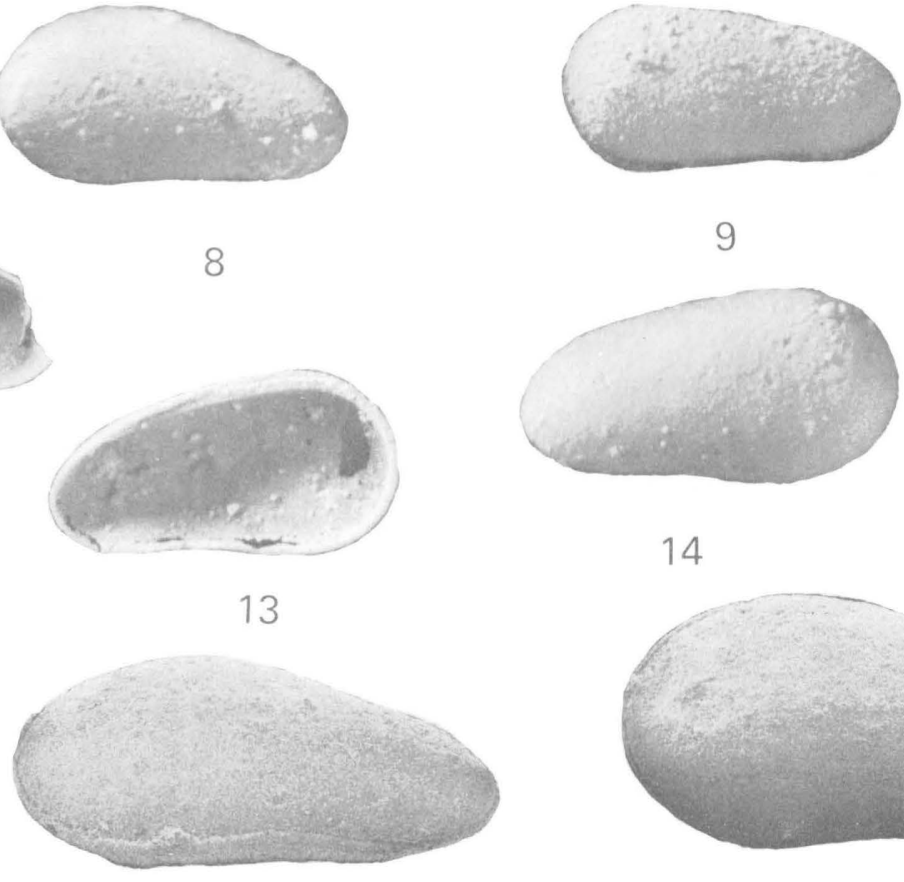

9

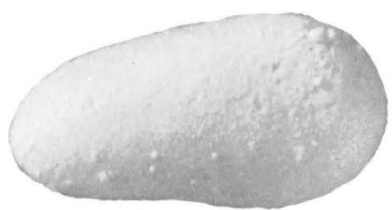

14

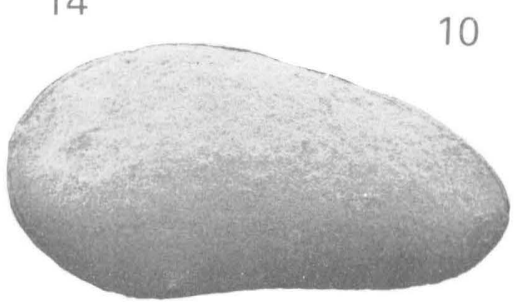

18

17

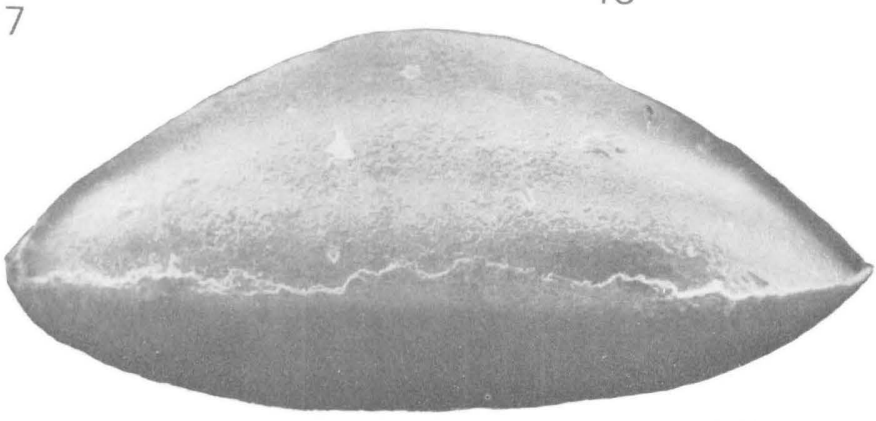

24

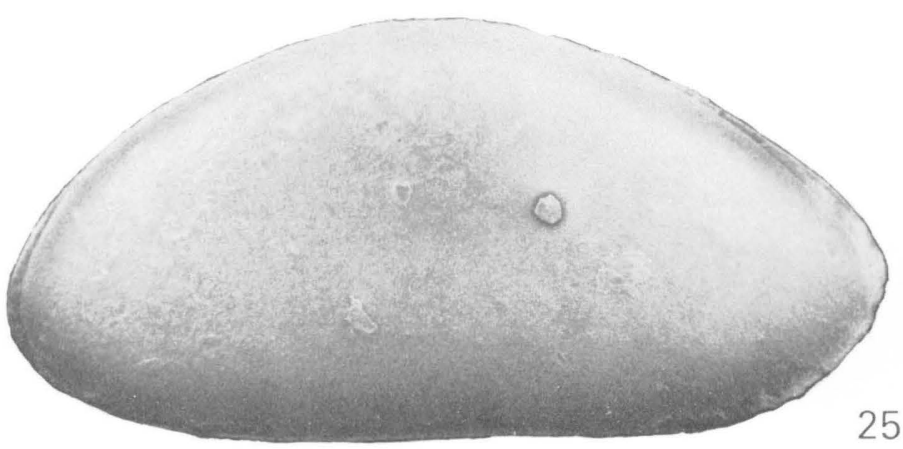

SHENANDOIA?, ELLIPTOCYPRITES, PHELOBYTHOCYPRIS, AND SILENIS 


\section{PLATE 19}

[Figures 3-5, 10, 11, and 14-17 are scanning electron micrographs]

FiguREs 1-5. Reversocypris? sp. (p. H71).

1, 2. Left?-lateral and right?-lateral views of carapace, figured specimen, USNM 240023, from the Strodes Creek Member of the Lexington Limestone, USGS colln. 7325-CO. $\times 30$.

3-5. Lateral $\left(10^{\circ}\right.$ tilt), laterodorsal $\left(45^{\circ}\right.$ tilt), and oblique anterodorsal $\left(45^{\circ}\right.$ tilt $)$ views of figured specimen, USNM $240023 . \times$ 100.

6-11. Pseudorayella sp. aff. P. ovalis Neckaja, 1960 (p. H71).

6, 8. Dorsal and right-lateral views of carapace, figured specimen, USNM 240058, from the Strodes Creek Member of the Lexington Limestone, USGS colln. 7318-CO. $\times 30$.

7, 9. Dorsal and left-lateral views of carapace, figured specimen, USNM 271097, from the Strodes Creek Member of the Lexington Limestone, USGS colln. 7312-CO. $\times 30$.

10 , 11. Lateral $\left(9^{\circ}\right.$ tilt) and lateroventral $\left(45^{\circ}\right.$ tilt) views of figured specimen, USNM $240058 . \times 50$.

12-17. Krausella sp. (p. H71).

12, 13. Lateral and dorsal views of carapace, figured specimen, USNM 240014, from the Strodes Creek Member of the Lexington Limestone, USGS colln. 7312-CO. $\times 30$.

14-17. Oblique anteroventral $\left(45^{\circ}\right.$ tilt), laterodorsal $\left(60^{\circ}\right.$ tilt), oblique posteroventral ( $45^{\circ}$ tilt), and lateral $\left(10^{\circ}\right.$ tilt $)$ views of figured specimen, USNM 240014. $\times 50$. 
GFOLOGICAL SURVEY

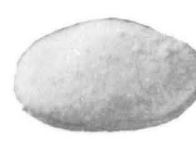

1

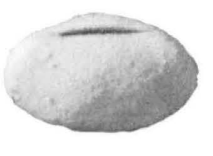

2
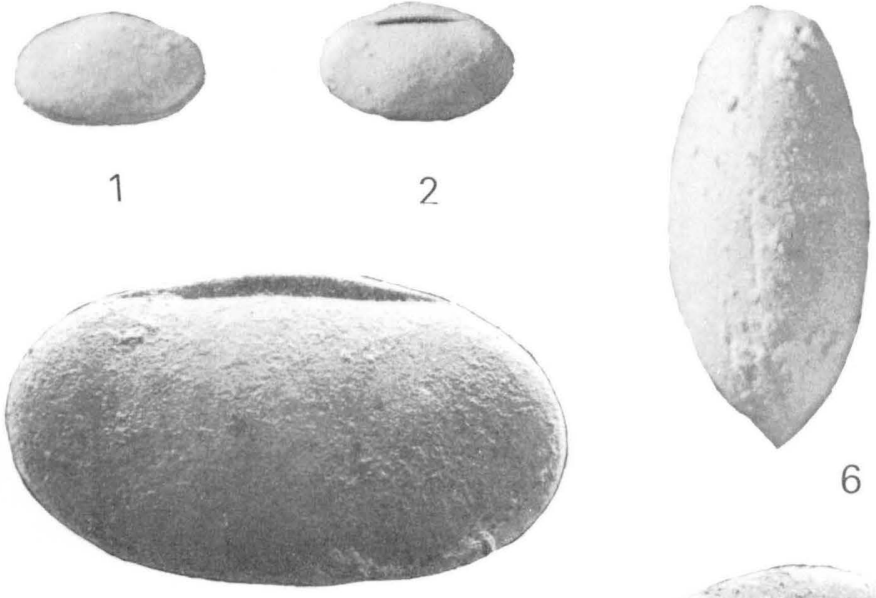

6
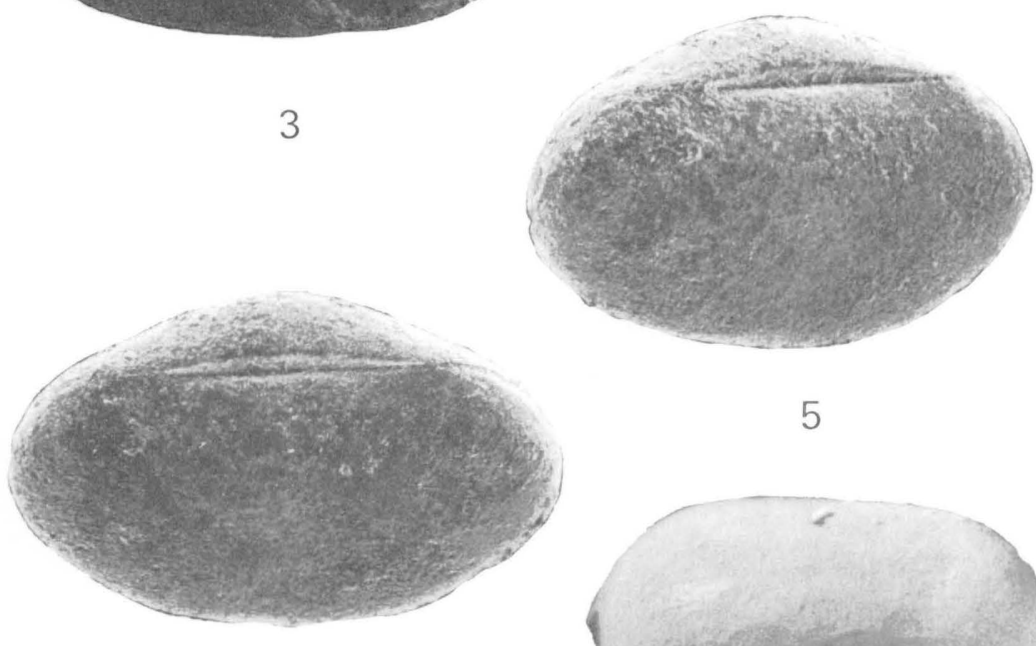

4

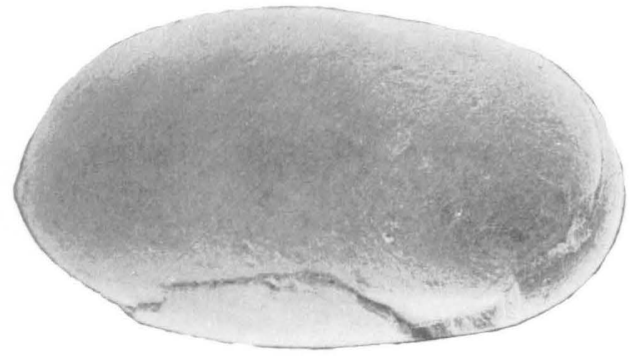

14

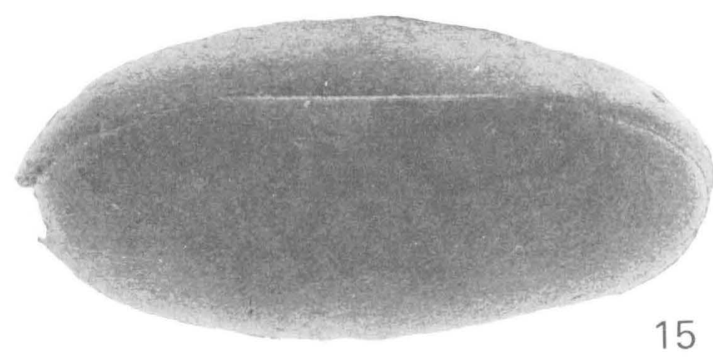

PROFESSIONAL PAPE? 1066-H PLATE 19
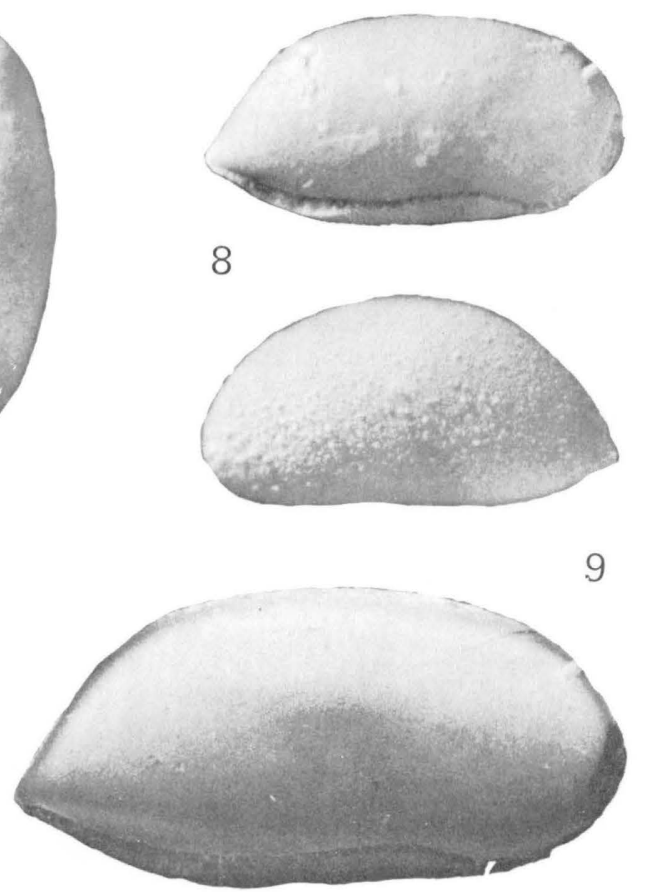

10
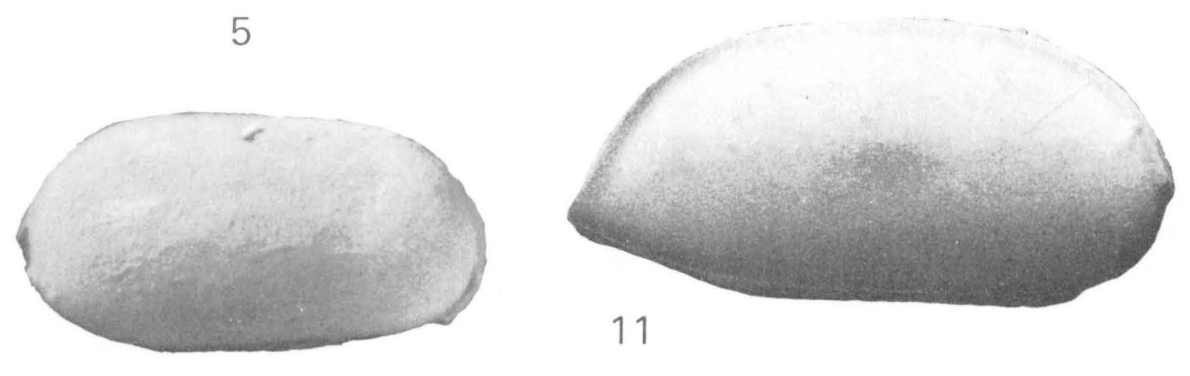

11

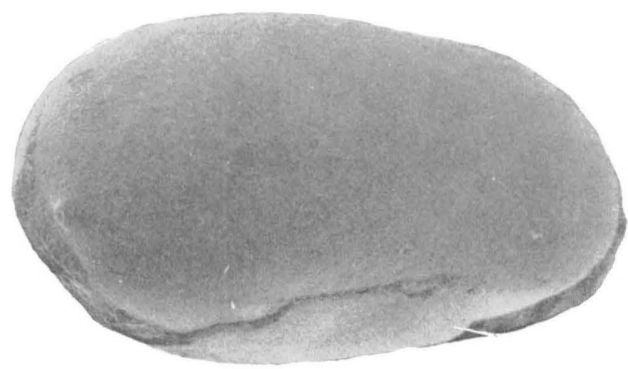

16

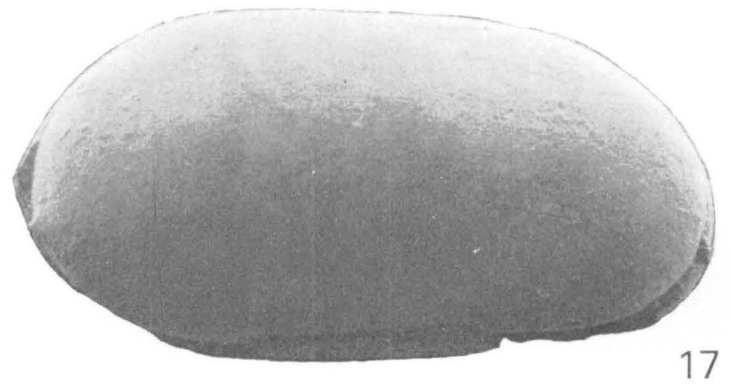

REVERSOCYPRIS?, PSEUDORAYELLA, AND KRAUSELLA 
